\title{
Development of New Geothermal Wellbore Holdup Correlations Using Flowing Well Data
}

Sabodh K. Garg John W. Pritchett James H. Alexander

March 2004

Idaho National Engineering and Environmental Laboratory Bechtel BWXT Idaho, LLC 


\section{DISCLAIMER}

This report was prepared as an account of work sponsored by an agency of the United States Government. Neither the United States Government nor any agency thereof, or any of their employees, makes any warranty, expressed or implied, or assumes any legal liability or responsibility for the accuracy, completeness, or usefulness of any information, apparatus, product or process disclosed, or represents that its use would not infringe privately owned rights. References herein to any specific commercial product, process, or service by trade name, trademark, manufacturer, or otherwise, does not necessarily constitute or imply its endorsement, recommendation, or favoring by the United States Government or any agency thereof. The views and opinions of authors expressed herein do not necessarily state or reflect those of the United States Government or any agency thereof. 


\title{
Development of New Geothermal Wellbore Holdup Correlations Using Flowing Well Data
}

\author{
Sabodh K. Garg \\ John W. Pritchett \\ James H. Alexander
}

March 2004

Science Application International Corporation San Diego, California 92121

Prepared for the

U.S. Department of Energy

Office of Energy Efficiency and Renewable Energy

Under DOE Idaho Operations Office

Contract DE-AC07-99ID13727 


\section{TABLE OF CONTENTS}

Section

Page

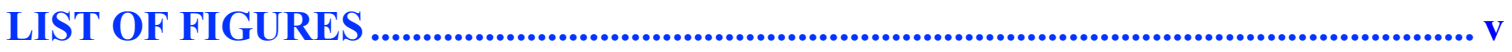

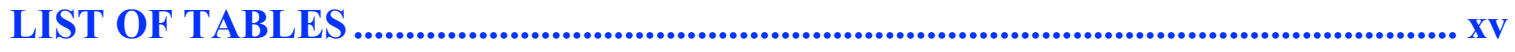

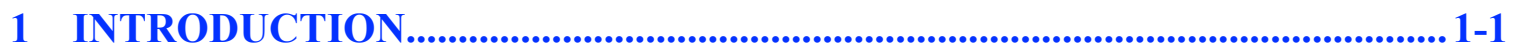

2 MATHEMATICAL MODELING OF FLUID FLOW IN GEOTHERMAL

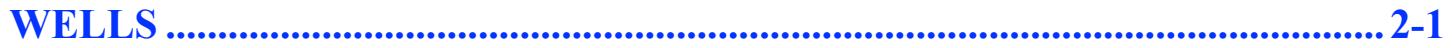

2.1 GENERAL APPROACH..................................................................... 2-1

2.2 SIMULATION OF FLUID FLOW .................................................... $2-1$

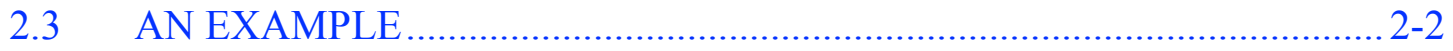

2.4 SIMULATION RESULTS .................................................................. 2-3

3 DEVELOPMENT OF A HOLDUP CORRELATION ...................................... 3-1

3.1 INTRODUCTION ....................................................................... $3-1$

3.2 HOLDUP CORRELATION PARAMETERS............................................ 3-3

3.3 HOLDUP CORRELATION ................................................................... $3-4$

3.4 VALIDATION OF HOLDUP CORRELATION ...................................... 3-7

3.5 HOLDUP CORRELATION FOR LOW MASS VELOCITY .................... 3-10

3.6 COMPARISON WITH SPINNER DATA ............................................... 3-10

3.7 FORTRAN SUBROUTINES ............................................................. 3-13

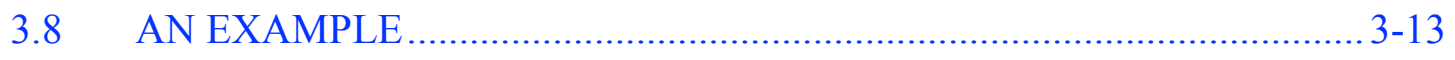

4 FUTURE WORK ............................................................................................................. 4-1

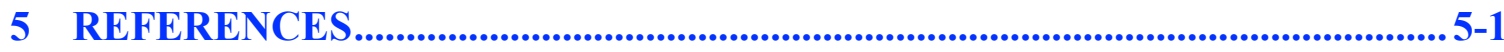

\section{APPENDICES}

A DUKLER I CORRELATION FOR FRICTIONAL PRESSURE DROP ......... A-1

B PARAMETERS USED TO MATCH DOWNHOLE PRESSURE AND

TEMPERATURE PROFILES ........................................................................... B-1

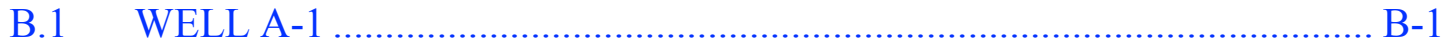

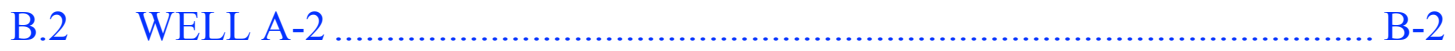

B.3 WELL A-4 ............................................................................ B-3

B.4 WELL A-6 ................................................................................. B-4

B.5 WELL A-7 .................................................................................. B-5

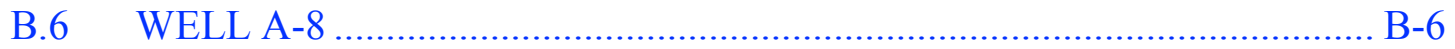

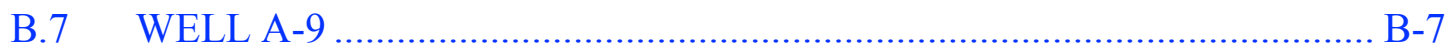

B.8 WELL A-10 ............................................................................... B-8

B.9 WELL A-11 ............................................................................ B 


\section{Section}

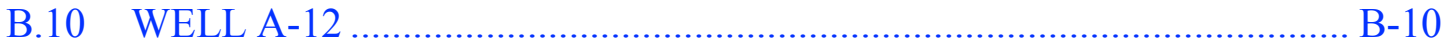

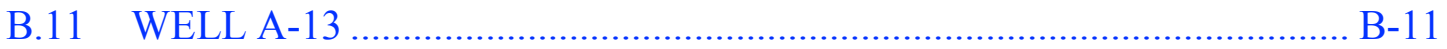

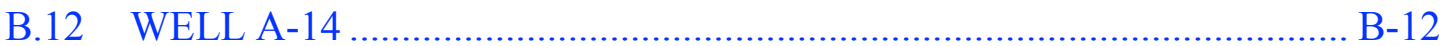

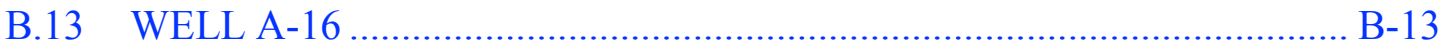

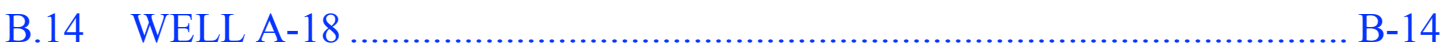

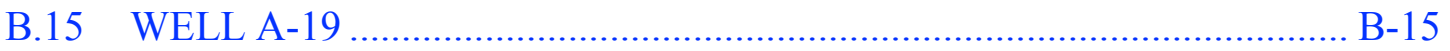

B.16 WELL A-20 .............................................................................. B-16

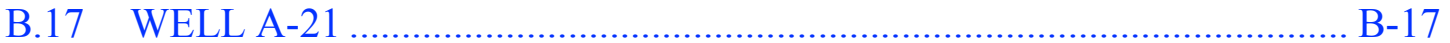

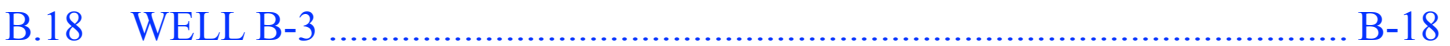

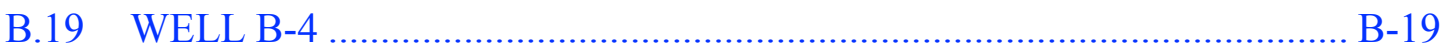

B.20 WELL B-5 …....................................................................... B-20

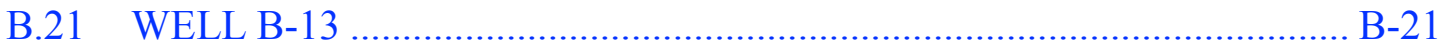

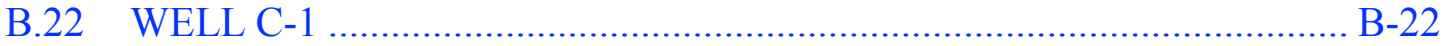

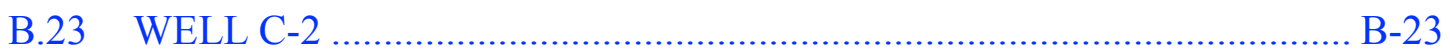

B.24 WELL C-3 …..................................................................... B-24

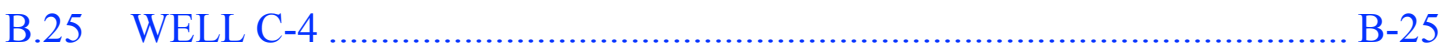

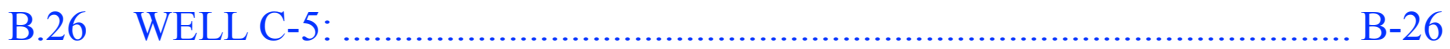

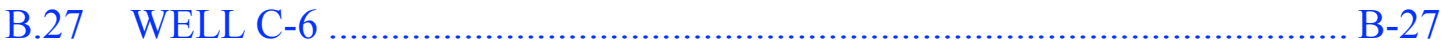

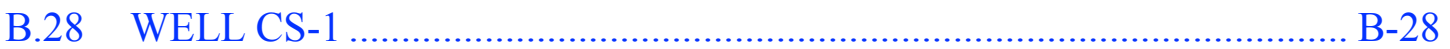

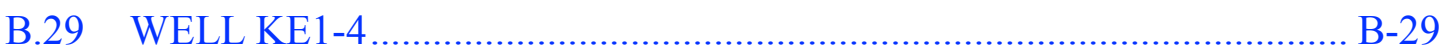

B.30 WELL KE1-9 .............................................................................. B-30

B.31 WELL KE1-11 ….................................................................... B-31

B.32 WELL KE1-17 ....................................................................... B-32

B.33 WELL KE1-19S ........................................................................ B-33

B.34 WELL KE1-22:........................................................................... B-34

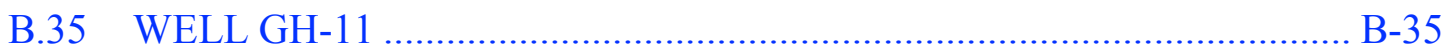

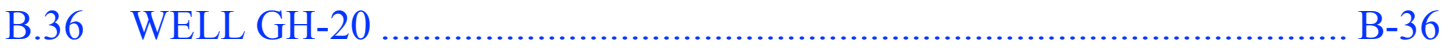

B.37 WELL S-2(I): ............................................................................ B-3

C NUMERICAL SIMULATIONS ....................................................................... C-1

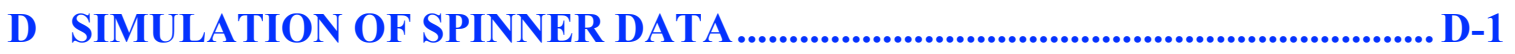

E FORTRAN SUBROUTINES USED FOR COMPUTING FLOW PARAMETER $K$ AND ITS DERIVATIVE WITH RESPECT TO

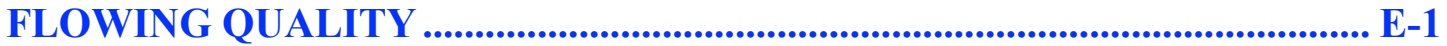

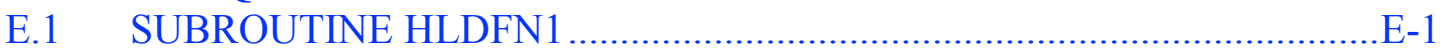

E.2 SUBROUTINE HLDFN2 ..................................................................

E.3 SUBROUTINE HOLDFK .................................................................... 


\section{LIST OF FIGURES}

Figure

Page

2.1 Pressure profile (triangle) recorded in discharging well A-4. The square indicates saturation pressure corresponding to local measured temperature.

The solid line is the computed pressure profile.

3.1 Two-phase fluid flow regimes according to Duns and Ros (1963). Also shown (as blue diamonds) are the data from geothermal boreholes (see Section 2).

3.2 A plot of $K$ versus $Z$. Data points (+), i.e., $K$ versus $Z$ values, in the figure were obtained by minimizing the pseudo-variance. $Z$ is defined by Equation (3.9) with $\alpha=0.0388887, \beta=0.0065170, \gamma=-0.0002960$, and $\omega=-0.1$. The green line denotes the best fit to the $K-Z$ data. The blue line was obtained by making slight modifications to the green line (see text).

3.3 Pressure profile (triangle) recorded in discharging well A-4. The square indicates saturation pressure corresponding to the local measured temperature. The solid line is the computed pressure profile using an adjustable holdup correlation (see Section 2 for details). The computed pressure profile using the modified correlation for $K(Z)$ is shown as a dashed line.

3.4 A plot of $K$ versus $Z$ for low mass velocity (mass velocity $<650 \mathrm{~kg} / \mathrm{s}^{-\mathrm{m}^{2}}$ ) profiles. Data points $(+)$, i.e., $K$ versus $Z$ values, in the figure were obtained by minimizing the pseudo-variance. $Z$ is defined by Equation (3.9) with $\alpha=-0.009546812, \beta=0.00975959, \gamma=-0.000149868$, and $\omega=-0.1$.The green line denotes the best fit to the $K-Z$ data. The blue line was obtained by making slight modifications to the green line (see text).

3.5. Comparison of the smoothed spinner response (triangles) with the computed spinner response (dashed line) for well A-4.

3.6. A pressure survey (triangle) recorded in slimhole SNLG87-29 on August 5, 1993. Also shown is the saturation pressure profile (square) corresponding to the temperature survey.

3.7. Pressure profile (triangle) recorded in the discharging slimhole. The square indicates saturation pressure corresponding to the local measured temperature. The solid (dashed line) line is the computed pressure profile assuming a smooth (rough) pipe.

3.8. Temperature profile (triangle) recorded in the discharging slimhole. The solid (dashed line) line is the computed temperature profile assuming a smooth (rough) pipe

3.9. Wellhead pressure versus mass flow rate for slimhole SNLG87-29. Measurements (symbols) and computed values (dashed line) 
C.1 Pressure profile (triangles) recorded in discharging well A-1. The squares indicate saturation pressure corresponding to the local measured temperature. The solid line is the computed pressure profile using an adjustable holdup correlation (see Section 2 for details). The computed pressure profile using the correlation(s) for $K(Z)$ developed in Section 3 is shown as a dashed line.

C.2 Pressure profile (triangles) recorded in discharging well A-2. The squares indicate saturation pressure corresponding to the local measured temperature. The solid line is the computed pressure profile using an adjustable holdup correlation (see Section 2 for details). The computed pressure profile using the correlation(s) for $K(Z)$ developed in Section 3 is shown as a dashed line.

C.3 Pressure profile (triangles) recorded in discharging well A-4. The squares indicate saturation pressure corresponding to the local measured temperature. The solid line is the computed pressure profile using an adjustable holdup correlation (see Section 2 for details). The computed pressure profile using the correlation(s) for $K(Z)$ developed in Section 3 is shown as a dashed line.

C.4 Pressure profile (triangles) recorded in discharging well A-6. The squares indicate saturation pressure corresponding to the local measured temperature. The solid line is the computed pressure profile using an adjustable holdup correlation (see Section 2 for details). The computed pressure profile using the correlation(s) for $K(Z)$ developed in Section 3 is shown as a dashed line.

C.5 Pressure profile (triangles) recorded in discharging well A-7. The squares indicate saturation pressure corresponding to the local measured temperature. The solid line is the computed pressure profile using an adjustable holdup correlation (see Section 2 for details). The computed pressure profile using the correlation(s) for $K(Z)$ developed in Section 3 is shown as a dashed line...

C.6 Pressure profile (triangles) recorded in discharging well A-8. The squares indicate saturation pressure corresponding to the local measured temperature. The solid line is the computed pressure profile using an adjustable holdup correlation (see Section 2 for details). The computed pressure profile using the correlation(s) for $K(Z)$ developed in Section 3 is shown as a dashed line.

C.7 Pressure profile (triangles) recorded in discharging well A-9. The squares indicate saturation pressure corresponding to the local measured temperature. The solid line is the computed pressure profile using an adjustable holdup correlation (see Section 2 for details). The computed pressure profile using the correlation(s) for $K(Z)$ developed in Section 3 is shown as a dashed line. 


\section{Figure}

Page

C.8 Pressure profile (triangles) recorded in discharging well A-10. The squares indicate saturation pressure corresponding to the local measured temperature. The solid line is the computed pressure profile using an adjustable holdup correlation (see Section 2 for details). The computed pressure profile using the correlation(s) for $K(Z)$ developed in Section 3 is shown as a dashed line.

C.9 Pressure profile (triangles) recorded in discharging well A-11. The squares indicate saturation pressure corresponding to the local measured temperature. The solid line is the computed pressure profile using an adjustable holdup correlation (see Section 2 for details). The computed pressure profile using the correlation(s) for $K(Z)$ developed in Section 3 is shown as a dashed line...

C.10 Pressure profile (triangles) recorded in discharging well A-12. The squares indicate saturation pressure corresponding to the local measured temperature. The solid line is the computed pressure profile using an adjustable holdup correlation (see Section 2 for details). The computed pressure profile using the correlation(s) for $K(Z)$ developed in Section 3 is shown as a dashed line.

C.11 Pressure profile (triangles) recorded in discharging well A-13. The squares indicate saturation pressure corresponding to the local measured temperature. The solid line is the computed pressure profile using an adjustable holdup correlation (see Section 2 for details). The computed pressure profile using the correlation(s) for $K(Z)$ developed in Section 3 is shown as a dashed line.

C.12 Pressure profile (triangles) recorded in discharging well A-14. The squares indicate saturation pressure corresponding to the local measured temperature. The solid line is the computed pressure profile using an adjustable holdup correlation (see Section 2 for details). The computed pressure profile using the correlation(s) for $K(Z)$ developed in Section 3 is shown as a dashed line.

C.13 Pressure profile (triangles) recorded in discharging well A-16. The squares indicate saturation pressure corresponding to the local measured temperature. The solid line is the computed pressure profile using an adjustable holdup correlation (see Section 2 for details). The computed pressure profile using the correlation(s) for $K(Z)$ developed in Section 3 is shown as a dashed line.

C.14 Pressure profile (triangles) recorded in discharging well A-18. The squares indicate saturation pressure corresponding to the local measured temperature. The solid line is the computed pressure profile using an adjustable holdup correlation (see Section 2 for details). The computed pressure profile using the correlation(s) for $K(Z)$ developed in Section 3 is shown as a dashed line. 
C.15 Pressure profile (triangles) recorded in discharging well A-19. The squares indicate saturation pressure corresponding to the local measured temperature. The solid line is the computed pressure profile using an adjustable holdup correlation (see Section 2 for details). The computed pressure profile using the correlation(s) for $K(Z)$ developed in Section 3 is shown as a dashed line.

C.16 Pressure profile (triangles) recorded in discharging well A-20. The squares indicate saturation pressure corresponding to the local measured temperature. The solid line is the computed pressure profile using an adjustable holdup correlation (see Section 2 for details). The computed pressure profile using the correlation(s) for $K(Z)$ developed in Section 3 is shown as a dashed line.

C.17 Pressure profile (triangles) recorded in discharging well A-21. The squares indicate saturation pressure corresponding to the local measured temperature. The solid line is the computed pressure profile using an adjustable holdup correlation (see Section 2 for details). The computed pressure profile using the correlation(s) for $K(Z)$ developed in Section 3 is shown as a dashed line.

C.18 Pressure profile (triangles) recorded in discharging well B-3. The squares indicate saturation pressure corresponding to the local measured temperature. The solid line is the computed pressure profile using an adjustable holdup correlation (see Section 2 for details). The computed pressure profile using the correlation(s) for $K(Z)$ developed in Section 3 is shown as a dashed line.

C.19 Pressure profile (triangles) recorded in discharging well B-4. The squares indicate saturation pressure corresponding to the local measured temperature. The solid line is the computed pressure profile using an adjustable holdup correlation (see Section 2 for details). The computed pressure profile using the correlation(s) for $K(Z)$ developed in Section 3 is shown as a dashed line.

C.20 Pressure profile (triangles) recorded in discharging well B-5. The squares indicate saturation pressure corresponding to the local measured temperature. The solid line is the computed pressure profile using an adjustable holdup correlation (see Section 2 for details). The computed pressure profile using the correlation(s) for $K(Z)$ developed in Section 3 is shown as a dashed line.

C.21 Pressure profile (triangles) recorded in discharging well B-13. The squares indicate saturation pressure corresponding to the local measured temperature. The solid line is the computed pressure profile using an adjustable holdup correlation (see Section 2 for details). The computed pressure profile using the correlation(s) for $K(Z)$ developed in Section 3 is shown as a dashed line. 
C.22 Pressure profile (triangles) recorded in discharging well C-1. The squares indicate saturation pressure corresponding to the local measured temperature. The solid line is the computed pressure profile using an adjustable holdup correlation (see Section 2 for details). The computed pressure profile using the correlation(s) for $K(Z)$ developed in Section 3 is shown as a dashed line.

C.23 Pressure profile (triangles) recorded in discharging well C-2. The squares indicate saturation pressure corresponding to the local measured temperature. The solid line is the computed pressure profile using an adjustable holdup correlation (see Section 2 for details). The computed pressure profile using the correlation(s) for $K(Z)$ developed in Section 3 is shown as a dashed line.

C.24 Pressure profile (triangles) recorded in discharging well C-3. The squares indicate saturation pressure corresponding to the local measured temperature. The solid line is the computed pressure profile using an adjustable holdup correlation (see Section 2 for details). The computed pressure profile using the correlation(s) for $K(Z)$ developed in Section 3 is shown as a dashed line.

C.25 Pressure profile (triangles) recorded in discharging well C-4. The squares indicate saturation pressure corresponding to the local measured temperature. The solid line is the computed pressure profile using an adjustable holdup correlation (see Section 2 for details). The computed pressure profile using the correlation(s) for $K(Z)$ developed in Section 3 is shown as a dashed line.

C.26 Pressure profile (triangles) recorded in discharging well C-5. The squares indicate saturation pressure corresponding to the local measured temperature. The solid line is the computed pressure profile using an adjustable holdup correlation (see Section 2 for details). The computed pressure profile using the correlation(s) for $K(Z)$ developed in Section 3 is shown as a dashed line.

C.27 Pressure profile (triangles) recorded in discharging well C-6. The squares indicate saturation pressure corresponding to the local measured temperature. The solid line is the computed pressure profile using an adjustable holdup correlation (see Section 2 for details). The computed pressure profile using the correlation(s) for $K(Z)$ developed in Section 3 is shown as a dashed line.

C.28 Pressure profile (triangles) recorded in discharging well CS-1. The squares indicate saturation pressure corresponding to the local measured temperature. The solid line is the computed pressure profile using an adjustable holdup correlation (see Section 2 for details). The computed pressure profile using the correlation(s) for $K(Z)$ developed in Section 3 is shown as a dashed line. 
C.29 Pressure profile (triangles) recorded in slim hole KE1-4 on November 12, 1983. The squares indicate saturation pressure corresponding to the local measured temperature. The solid line is the computed pressure profile using an adjustable holdup correlation (see Section 2 for details). The computed pressure profile using the correlation(s) for $K(Z)$ developed in Section 3, shown as a dashed line, was obtained using a reduced discharge rate $(6.5 \mathrm{~kg} / \mathrm{s}$ instead of $7.08 \mathrm{~kg} / \mathrm{s})$

C.30 Pressure profile (triangles) recorded in slim hole KE1-4 on November 13, 1983. The squares indicate saturation pressure corresponding to the local measured temperature. The solid line is the computed pressure profile using an adjustable holdup correlation (see Section 2 for details). The correlation for $K(Z)$ developed in Section 3 results in choking (see Section 3 for details) for discharge rates greater than $6.5 \mathrm{~kg} / \mathrm{s}$; for the computed profile corresponding to the latter discharge rate, see Figure C.29.

C.31 Pressure profile (triangles) recorded in discharging well KE1-9. The squares indicate saturation pressure corresponding to the local measured temperature. The solid line is the computed pressure profile using an adjustable holdup correlation (see Section 2 for details). The computed pressure profile using the correlation(s) for $K(Z)$ developed in Section 3 is shown as a dashed line.

C.32 Pressure profile (triangles) recorded in discharging well KE1-11. The squares indicate saturation pressure corresponding to the local measured temperature. The solid line is the computed pressure profile using an adjustable holdup correlation (see Section 2 for details). The computed pressure profile using the correlation(s) for $K(Z)$ developed in Section 3 is shown as a dashed line.

C.33 Pressure profile (triangles) recorded in well KE1-17 on March 30, 1986. The squares indicate saturation pressure corresponding to the local measured temperature. The solid line is the computed pressure profile using an adjustable holdup correlation (see Section 2 for details). The computed pressure profile using the correlation(s) for $K(Z)$ developed in Section 3 is shown as a dashed line.

C.34 Pressure profile (triangles) recorded in well KE1-17 on April 4, 1986. The squares indicate saturation pressure corresponding to the local measured temperature. The solid line is the computed pressure profile using an adjustable holdup correlation (see Section 2 for details). The computed pressure profile using the correlation(s) for $K(Z)$ developed in Section 3 is shown as a dashed line. 
C.35 Pressure profile (triangles) recorded in well KE1-19S on September 1, 1986. The squares indicate saturation pressure corresponding to the local measured temperature. The solid line is the computed pressure profile using an adjustable holdup correlation (see Section 2 for details). The computed pressure profile using the correlation(s) for $K(Z)$ developed in Section 3, shown as a dashed line, was obtained using a reduced discharge rate $(23.0 \mathrm{~kg} / \mathrm{s}$ instead of $23.9 \mathrm{~kg} / \mathrm{s})$.

C.36 Pressure profile (triangles) recorded in well KE1-19S on September 16, 1986. The squares indicate saturation pressure corresponding to the local measured temperature. The solid line is the computed pressure profile using an adjustable holdup correlation (see Section 2 for details). The computed pressure profile using the correlation(s) for $K(Z)$ developed in Section 3 is shown as a dashed line.

C.37 Pressure profile (triangles) recorded in well KE1-22 on February 10, 1987. The squares indicate saturation pressure corresponding to the local measured temperature. The solid line is the computed pressure profile using an adjustable holdup correlation (see Section 2 for details). The computed pressure profile using the correlation(s) for $K(Z)$ developed in Section 3 is shown as a dashed line.

C.38 Pressure profile (triangles) recorded in well KE1-22 on February 25, 1987. The squares indicate saturation pressure corresponding to the local measured temperature. The solid line is the computed pressure profile using an adjustable holdup correlation (see Section 2 for details). The computed pressure profile using the correlation(s) for $K(Z)$ developed in Section 3 is shown as a dashed line.

C.39 Pressure profile (triangles) recorded in well GH-11 on July 19, 1991. The squares indicate saturation pressure corresponding to the local measured temperature. The solid line is the computed pressure profile using an adjustable holdup correlation (see Section 2 for details). The computed pressure profile using the correlation(s) for $K(Z)$ developed in Section 3 is shown as a dashed line.

C.40 Pressure profile (triangles) recorded in well GH-11 on July 20, 1991. The squares indicate saturation pressure corresponding to the local measured temperature. The solid line is the computed pressure profile using an adjustable holdup correlation (see Section 2 for details). The computed pressure profile using the correlation(s) for $K(Z)$ developed in Section 3 is shown as a dashed line.

C.41 Pressure profile (triangles) recorded in well GH-20 on April 24, 1991. The squares indicate saturation pressure corresponding to the local measured temperature. The solid line is the computed pressure profile using an adjustable holdup correlation (see Section 2 for details). The computed pressure profile using the correlation(s) for $K(Z)$ developed in Section 3 is shown as a dashed line. 
C.42 Pressure profile (triangles) recorded in well GH-20 on April 25, 1991. The squares indicate saturation pressure corresponding to the local measured temperature. The solid line is the computed pressure profile using an adjustable holdup correlation (see Section 2 for details). The computed pressure profile using the correlation(s) for $K(Z)$ developed in Section 3 is shown as a dashed line.

C.43 Pressure profile (triangles) recorded in well GH-20 on April 26, 1991. The squares indicate saturation pressure corresponding to the local measured temperature. The solid line is the computed pressure profile using an adjustable holdup correlation (see Section 2 for details). The computed pressure profile using the correlation(s) for $K(Z)$ developed in Section 3 is shown as a dashed line.

C.44 Pressure profile (triangles) recorded in discharging well S-2(i). The squares indicate saturation pressure corresponding to the local measured temperature. The solid line is the computed pressure profile using an adjustable holdup correlation (see Section 2 for details). The computed pressure profile using the correlation(s) for $K(Z)$ developed in Section 3 is shown as a dashed line.

D.1. Comparison of the smoothed spinner response (triangles) with the computed spinner response (dashed line) for well A-1.

D.2. Comparison of the smoothed spinner response (triangles) with the computed spinner response (dashed line) for well A-2.

D.3. Comparison of the smoothed spinner response (triangles) with the computed spinner response (dashed line) for well A-4.

D.4. Comparison of the smoothed spinner response (triangles) with the computed spinner response (dashed line) for well A-6.

D.5. Comparison of the smoothed spinner response (triangles) with the computed spinner response (dashed line) for well A-7.

D.6. Comparison of the smoothed spinner response (triangles) with the computed spinner response (dashed line) for well A-8

D.7. Comparison of the smoothed spinner response (triangles) with the computed spinner response (dashed line) for well A-9.

D.8. Comparison of the smoothed spinner response (triangles) with the computed spinner response (dashed line) for well A-10.

D.9. Comparison of the smoothed spinner response (triangles) with the computed spinner response (dashed line) for well A-11.

D.10. Comparison of the smoothed spinner response (triangles) with the computed spinner response (dashed line) for well A-12.

D.11. Comparison of the smoothed spinner response (triangles) with the computed spinner response (dashed line) for well A-13.

D.12. Comparison of the smoothed spinner response (triangles) with the computed spinner response (dashed line) for well A-14. 
D.13. Comparison of the smoothed spinner response (triangles) with the computed spinner response (dashed line) for well A-16.

D.14. Comparison of the smoothed spinner response (triangles) with the computed spinner response (dashed line) for well A-18.

D.15. Comparison of the smoothed spinner response (triangles) with the computed spinner response (dashed line) for well A-19.

D.16. Comparison of the smoothed spinner response (triangles) with the computed spinner response (dashed line) for well A-20.

D.17. Comparison of the smoothed spinner response (triangles) with the computed spinner response (dashed line) for well A-21.

D.18. Comparison of the smoothed spinner response (triangles) with the computed spinner response (dashed line) for well B-3.

D.19. Comparison of the smoothed spinner response (triangles) with the computed spinner response (dashed line) for well B-4.

D.20. Comparison of the smoothed spinner response (triangles) with the computed spinner response (dashed line) for well B-5.

D.21. Comparison of the smoothed spinner response (triangles) with the computed spinner response (dashed line) for well B-13.

D.22. Comparison of the smoothed spinner response (triangles) with the computed spinner response (dashed line) for well C-1

D.23. Comparison of the smoothed spinner response (triangles) with the computed spinner response (dashed line) for well C-2.

D.24. Comparison of the smoothed spinner response (triangles) with the computed spinner response (dashed line) for well C-3.

D.25. Comparison of the smoothed spinner response (triangles) with the computed spinner response (dashed line) for well C-4.

D.26. Comparison of the smoothed spinner response (triangles) with the computed spinner response (dashed line) for well C-5.

D.27. Comparison of the smoothed spinner response (triangles) with the computed spinner response (dashed line) for well C-6.

D.28. Comparison of the smoothed spinner response (triangles) with the computed spinner response (dashed line) for well CS-1.

D.29 Comparison of the smoothed spinner response (triangles) recorded on July 19, 1991, with the computed spinner response (dashed line) for well GH-1.

D.30. Comparison of the smoothed spinner response (symbols) recorded on July 20, 1991, with the computed spinner response (solid line) for well $\mathrm{GH}-11$. 


\section{LIST OF TABLES}

Table

Page

2.1 Flow parameters computed from a simulation of downhole pressure profile in well A-4 (see Figure 2.1). Row 1 (Row 21) corresponds to parameter values at the bottom (wellhead) of the simulated depth interval (Figure 2.1).

3.1 Comparison of wellhead pressures for high mass velocity profiles (mass velocity $>687 \mathrm{~kg} / \mathrm{s}-\mathrm{m}^{2}$ ) computed using (1) best fit correlation for $K(Z)$, and (2) modified correlation for $K(Z)$ with data.

3.2 Comparison of wellhead pressures for low mass velocity profiles (mass velocity $<650 \mathrm{~kg} / \mathrm{s}-\mathrm{m}^{2}$ ) computed using (1) best fit correlation for $K(Z)$, and (2) modified correlation for $K(Z)$ with data.

3.3. Comparison of the smoothed spinner response with the computed response for wells in the dataset. 


\section{INTRODUCTION}

An ability to predict both the quantity of fluid that can be produced and its thermodynamic state (pressure, temperature, enthalpy, gas content, salinity, etc.) is essential for estimating the total usable energy of a geothermal resource. Numerical reservoir simulators can be utilized to calculate the thermodynamic state of the fluid at the underground feed-zone(s) at which the fluid enters the wellbore. The computation of the well-head fluid properties from a given underground state (or vice-versa) requires the use of a wellbore simulator.

The fluid flow in the wellbore is not amenable to strict analytical treatment. Depending upon the relative amounts of gas and liquid, a variety of flow patterns can occur in the pipe. At small gas loadings, bubble flow takes place. An increase in gas flow rate can result in slug, churn or annular flow. Existing methods for treating two-phase flow in a wellbore require use of empirical correlations for friction factor and for liquid hold-up.

Because of slip between the gas and liquid phases, the flowing gas quality $Q_{f}$ is generally different from the in situ gas quality $Q_{s}$. The liquid hold-up correlation provides a relationship between $Q_{f}$ and $Q_{s}$. Almost all of the existing holdup correlations (see e.g., Ansari et al., 1994; Aziz et al., 1972; Beggs and Brill, 1973; Duns and Ros, 1963; Hagedorn and Brown, 1965; Hadgu, 1989; Hughmark, 1962; Hughmark and Pressburg, 1961; Orkiszewski, 1967) are based on flow in two-phase petroleum (oil and gas) systems. At present, there does not exist a sufficient basis for selecting one or another of these correlations to simulate two-phase flow in geothermal wellbores. Utilization of different correlations very often yields widely differing results (see e.g., Finger, et al., 1999).

Recent availability of high quality downhole pressure/temperature/spinner logs from flowing geothermal wells suggests that it may be worthwhile to take a fresh look at the empirical correlations for liquid hold-up. The present research effort is designed to develop new hold-up correlations for geothermal applications using data from flowing geothermal wells. To support this research work, Unocal has agreed to release proprietary downhole logs and other required data from 42 wells. Data sets are also available from flowing wells from several Japanese geothermal fields; these data sets were previously supplied to SAIC (previously Maxwell Technologies) by various Japanese developers as part of a DOE/Sandia funded research program. In addition, Caithness has supplied data for one well. Because of programmatic reasons, this research effort is divided in to several phases.

During FY 2001, SAIC was asked by Bechtel to (1) evaluate the available well data for completeness and internal consistency, and (2) identify high quality well data for use in developing new correlations. As a result of a detailed examination of well data made available by Unocal and various Japanese developers, SAIC identified (see Garg and Pritchett, 2001) over 30 wells with high quality discharge (mass discharge rate and enthalpy) 
and downhole pressure and temperature data. The data set encompasses a wide range of discharge enthalpies (i.e., moderate enthalpy wells producing from liquid feedzones, and wells with enthalpies approaching the enthalpy of saturated steam), and casing diameters (ID's ranging from $100 \mathrm{~mm}$ to $384 \mathrm{~mm}$ ). As far as fluid composition is concerned, the data set leaves something to be desired. The salinity and non-condensable gas content of most of the wells in the data set are less than $1.5 \%$ and $1 \%$ (mass fraction of the produced fluid), respectively. In any event, the present data set is eminently suitable for developing a new empirical liquid hold-up correlation for geothermal wells.

In FY 2002, Bechtel asked SAIC to use the above-mentioned well data to devise new liquid hold-up correlations for geothermal wells. To make the problem tractable, a two-stage research program was devised. During the first stage (FY 2002 and 2003), a new correlation was developed that is restricted to the cased section of geothermal wells. Obviously, the fluid flow in the cased section is much simpler than in the open hole or in the slotted/blank liner section. With the exception of the work by Hadgu (1989), all of the published papers treat two-phase flow in a pipe (i.e., the cased section). The well data will be used in a second stage (FY 2004) to formulate a separate holdup correlation for the open hole/slotted liner section of geothermal wells.

The present report describes the work performed by SAIC during FY 2002 and FY 2003. Our methodology for developing a hold-up correlation is outlined in Section 2. The downhole pressure/temperature profiles were simulated using an existing wellbore code with an adjustable hold-up correlation. The results of these simulations were employed to generate a multi-parameter (flowing quality, static quality, flowing gas volume fraction, gas and liquid densities, gas and liquid viscosities etc.) data set. The latter data are used in Section 3 to relate flowing gas quality to other parameters. Finally, in Section 4, future work (FY 2004 and beyond) is described. 


\section{MATHEMATICAL MODELING OF FLUID FLOW IN GEOTHERMAL WELLS}

\section{$2.1 \quad$ GENERAL APPROACH}

The pressure drop associated with two-phase fluid transport in a geothermal well represents the combined effects of friction, acceleration, and the loss of elevation. While the pressure drop due to acceleration is usually small in single-phase liquid flow in a pipe, it is very often the most important component in two-phase flow. The fluid flow in a geothermal well is not amenable to strict analytical treatment. For two-phase flow, it is necessary to supplement mass, momentum and energy balance relations by empirical correlations for (1) friction factor, and (2) liquid hold-up. In the following, a wellbore simulator, incorporating an existing friction factor correlation and an adjustable liquid hold-up correlation, is used to match the downhole pressure profiles in flowing wells. The simulation results are employed to generate a multi-parameter (flowing quality, static quality, in situ liquid and gas volume fractions, gas and liquid viscosities, etc.) data set. The data set forms the basis for the development of a new liquid hold-up correlation (Section 3).

\subsection{SIMULATION OF FLUID FLOW}

The downhole pressure (and temperature) profiles in the cased portion of flowing wells (see Garg and Pritchett, 2001, for a critical appraisal of the data set) have been simulated using a specially modified version (see below) of the wellbore computer simulation program WELBOR (Pritchett, 1985). The WELBOR code treats the steady flow of liquid water and steam up a borehole. The user provides parameters describing the well geometry (inside diameter and angle of deviation with respect to the vertical along the hole length), a stable formation temperature distribution with depth, and an "effective thermal conductivity" as a function of depth representing the effects of conductive heat transfer between the fluid in the wellbore and the surrounding formation. For boreholes with twophase flow at the bottom of the cased portion, the fluid state is prescribed by specifying flowing pressure, flowing enthalpy, salinity, and gas content.

In two-phase water/steam flow, pressure and temperature are not independent of each other. For any reasonable value of effective thermal conductivity $\kappa$, the downhole flowing enthalpy may be adjusted to yield the appropriate pressure, and hence temperature, distribution in the wellbore, and flowing wellhead enthalpy. Matching the pressure/ temperature distribution in the wellbore and flowing wellhead enthalpy does not constrain the heat loss and downhole (e.g., at the bottom of the cased section) enthalpy. Since the flowing downhole enthalpy is not a measured quantity, it is not possible to determine a unique value for heat loss in the presence of two-phase flow. It is, therefore, appropriate to eliminate 
effective thermal conductivity as a free parameter, and use a constant value for $\kappa$. Except for slimhole KE1-4 (see below), $\kappa$ was assumed to be $4 \mathrm{~W} / \mathrm{m}-{ }^{\circ} \mathrm{C}$.

In WELBOR, the frictional pressure gradient is computed using the Dukler I (or Dukler II) correlation (Dukler et al., 1964), and a user prescribed roughness factor, $\varepsilon$. The Dukler II correlation gives a much larger pressure drop than the Dukler I correlation. Numerical experiments (Garg and Combs, 2002; also present study) have shown that it is usually necessary to use the Dukler I correlation in order to match the reported discharge rate and enthalpy data from geothermal boreholes. It was, therefore, decided to use the Dukler I correlation (see Appendix A for a description of Dukler I correlation) for the present study. The roughness factor, $\varepsilon$, may vary with depth. For most of the pressure profiles considered herein, the roughness factor was assumed to be zero. In a few cases, it was found necessary to use a non-zero value for $\varepsilon$.

The relative slip between the liquid and gas phases is treated in WELBOR using a modified version of the Hughmark liquid holdup correlation (Hughmark, 1962). The slippage rate may vary between the value given by the Hughmark correlation and no slip at all, according to the value of a user specified parameter, $\eta$, which varies between zero (no slip) and unity (Hughmark). For the present application, the WELBOR code was modified to allow $\eta$ to vary as a function of depth. For all of the pressure profiles considered herein, it was found that at most two values of $\eta$ (and a small transition zone in between) were required to produce a satisfactory match between the measured and computed pressures.

Given the fluid state (pressure, enthalpy, salinity, gas content) at the bottom of the cased interval and the mass discharge rate, a wellbore simulator such as WELBOR can be used to compute the fluid state along the wellbore and at the wellhead. The principal parameters that may be varied to match the measured conditions along the wellbore (pressure and temperature) and at the wellhead (pressure, temperature, steam and liquid flow rates, liquid salinity, gas content of steam) are (1) flowing enthalpy, salinity and gas content at the bottom of the cased interval, (2) holdup parameter, $\eta$, and (3) interior roughness factor, $\varepsilon$.

\subsection{AN EXAMPLE}

To illustrate the computational procedure, it is useful to consider Unocal well A-4 (Garg and Pritchett, 2001). Well A-4 is cased and cemented to a depth of $888.5 \mathrm{mTVD}$ (901.6 mMD). The following well geometry is assumed for the cased section of well A-1:

\begin{tabular}{|c|c|c|c|}
\hline $\begin{array}{c}\text { Measured } \\
\text { Depth } \\
\text { (meters) }\end{array}$ & $\begin{array}{c}\text { Vertical } \\
\text { Depth } \\
\text { (meters) }\end{array}$ & $\begin{array}{c}\text { Angle with } \\
\text { Vertical } \\
\text { (Degrees) }\end{array}$ & $\begin{array}{c}\text { Internal } \\
\text { Diameter } \\
(\mathrm{mm})\end{array}$ \\
\hline $0-277.4$ & $0-277.4$ & 0.000 & 384 \\
\hline $277.4-901.6$ & $277.4-888.5$ & 14.068 & 315 \\
\hline
\end{tabular}

The measured pressures in the flowing well are in good agreement with the saturation pressure for pure water corresponding to the measured temperatures (Garg and Pritchett, 2001). A pressure of 23.49 bars (taken as the average of measured and saturation pressures) 
was recorded in the flowing well at $888.5 \mathrm{mTVD}$. The reported discharge rate and wellhead enthalpy were $135( \pm 3) \mathrm{kg} / \mathrm{s}$ and $1089( \pm 12) \mathrm{kJ} / \mathrm{kg}$, respectively. Total dissolved solids content of the separated liquid was $14600( \pm 150) \mathrm{ppm}$; the non-condensable gas content of the steam was $0.68( \pm 0.1) \%$.

The stable formation temperature (Garg and Pritchett, 2001) was approximated by the following temperature distribution using linear interpolations between tabulated data.

\begin{tabular}{|c|c|}
\hline $\begin{array}{c}\text { Vertical Depth } \\
\text { (meters) }\end{array}$ & $\begin{array}{c}\text { Temperature } \\
\text { (Degrees Celsius) }\end{array}$ \\
\hline 0 & 27 \\
305 & 68 \\
754 & 212 \\
888.5 & 227 \\
\hline
\end{tabular}

The best match to the downhole pressure profile and wellhead fluid state (pressure, enthalpy, salinity, gas content) was obtained using the following values for the unknown model parameters:

Flowing enthalpy at $888.5 \mathrm{mTVD}$ $=1102 \mathrm{~kJ} / \mathrm{kg}$

Fluid (liquid + steam) salinity at $888.5 \mathrm{mTVD} \quad=0.012 \mathrm{~kg} / \mathrm{kg}$

Fluid (liquid + steam) gas content at $888.5 \mathrm{mTVD}=0.0011 \mathrm{~kg} / \mathrm{kg}$

Hughmark parameter, $\eta$

$=0.09$ for depths $<350 \mathrm{~m}$

$=0.09+0.0062($ depth -350$)$ for

$350 \mathrm{~m}<$ depth $<400 \mathrm{~m}$

Roughness factor, $\varepsilon$

$=0.40$ for depths $>400 \mathrm{~m}$

$=0.00 \mathrm{~mm}$ for all depths

The computed pressure profile is compared with the measurements in Figure 2.1; the agreement is excellent. The computed fluid state at the wellhead (fluid enthalpy: $1089 \mathrm{~kJ} / \mathrm{kg}$, liquid phase salinity: $14,300 \mathrm{ppm}$; steam phase gas content: $0.67 \%$ ) is very close to the measurements.

\subsection{SIMULATION RESULTS}

An essentially identical procedure was used to fit the downhole pressure and wellhead fluid state measurements for all of the wells in the dataset. Parameters used to match downhole pressure and temperature profiles are given in Appendix B. The computed pressure profiles are compared with the measurements in Appendix $\mathrm{C}$; the agreement is very good in most cases.

The data for the Unocal wells (A-, B- and C- wells, and presumably the single Caithness well) were obtained while these wells were discharging in a more or less stable manner. Available data for these wells include the NCG and salt content of the discharge 


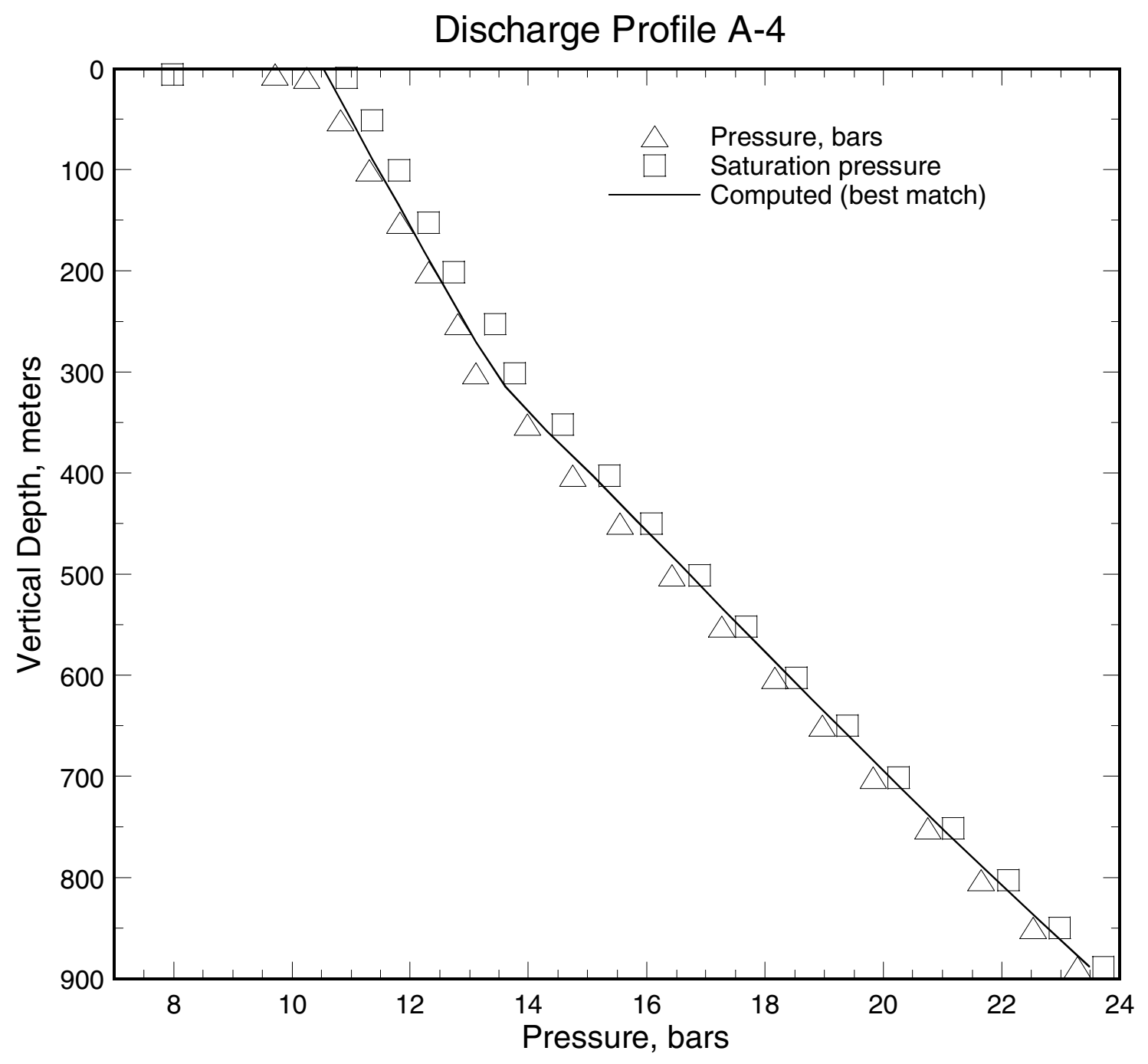

Figure 2.1. Pressure profile (triangle) recorded in discharging well A-4. The square indicates saturation pressure corresponding to local measured temperature. The solid line is the computed pressure profile. 
stream in addition to an estimate of the error bounds for the discharge rate and wellhead enthalpy. By way of contrast, data for the Japanese wells (KE-, GH- and S- wells) were obtained during short term (from a few hours to a few days duration) discharge tests. No $\mathrm{NCG}$ and salinity measurements are available for the production fluid from these short term tests. Also, discharge rate and wellhead enthalpy measurements from the short term tests may not be very accurate; these errors are likely to be most problematical for wells with very low discharge rates (e.g., KE1-4, KE1-9, KE1-11, S-2). To simulate the pressure profiles in $\mathrm{KE} 1-4$, an unusually low value for effective thermal conductivity had to be assumed. For well KE1-17, an unrealistically large value for the roughness factor was required to match the deeper part of the pressure profile; it is likely that the quoted discharge rate and wellhead enthalpy measurements for KE1-17 are in error. Although flow data for the Japanese wells in the dataset are liable to be less accurate than for the Unocal wells, it was decided to retain these data, since the Japanese well test data are typical of measurements taken during the exploration phase.

The results of these downhole pressure/temperature simulations (Appendices B and C) were used to define the fluid state and associated quantities (e.g., liquid and gas velocities) in the cased section of all the wells in the dataset. Somewhat arbitrarily, it was decided to use 21 equally spaced points along each downhole profile to create a dataset (see Table 2.1 for an example) for formulating a new holdup correlation (Section 3). 
Table 2.1. Flow parameters computed from a simulation of downhole pressure profile in well A-4 (see Figure 2.1). Row 1 (Row 21) corresponds to parameter values at the bottom (wellhead) of the simulated depth interval (Figure 2.1).

\begin{tabular}{|c|c|c|c|c|c|}
\hline $\begin{array}{l}\text { Flow Parameter } \\
\qquad(K)\end{array}$ & $\begin{array}{l}\text { Reynolds } \\
\text { Number } \\
\quad(R n)\end{array}$ & $\begin{array}{l}\text { Froude Number } \\
\qquad(F r)\end{array}$ & $\begin{array}{c}\text { Flowing Liquid } \\
\text { Volume } \\
\text { Fraction } \\
\left(Y_{l}\right)\end{array}$ & $\begin{array}{c}\text { Weber } \\
\text { Number } \\
(W e)\end{array}$ & $\begin{array}{l}\text { In situ Liquid } \\
\text { Fraction } \\
\left(S_{l}\right)\end{array}$ \\
\hline $0.944111 \mathrm{E}+00$ & $0.154495 \mathrm{E}+08$ & $0.402794 \mathrm{E}+02$ & $0.124374 \mathrm{E}+00$ & $0.138119 \mathrm{E}+05$ & $0.173310 \mathrm{E}+00$ \\
\hline $0.944493 \mathrm{E}+00$ & $0.158112 \mathrm{E}+08$ & $0.442975 \mathrm{E}+02$ & $0.115473 \mathrm{E}+00$ & $0.144626 \mathrm{E}+05$ & $0.164570 \mathrm{E}+00$ \\
\hline $0.944852 \mathrm{E}+00$ & $0.161676 \mathrm{E}+08$ & $0.486497 \mathrm{E}+02$ & $0.107140 \mathrm{E}+00$ & $0.151282 \mathrm{E}+05$ & $0.156380 \mathrm{E}+00$ \\
\hline $0.945192 \mathrm{E}+00$ & $0.165138 \mathrm{E}+08$ & $0.532888 \mathrm{E}+02$ & $0.994595 \mathrm{E}-01$ & $0.157775 \mathrm{E}+05$ & $0.148820 \mathrm{E}+00$ \\
\hline $0.945516 \mathrm{E}+00$ & $0.168505 \mathrm{E}+08$ & $0.582344 \mathrm{E}+02$ & $0.923534 \mathrm{E}-01$ & $0.164078 \mathrm{E}+05$ & $0.141810 \mathrm{E}+00$ \\
\hline $0.945830 \mathrm{E}+00$ & $0.171789 \mathrm{E}+08$ & $0.635153 \mathrm{E}+02$ & $0.857512 \mathrm{E}-01$ & $0.170178 \mathrm{E}+05$ & $0.135280 \mathrm{E}+00$ \\
\hline $0.946131 \mathrm{E}+00$ & $0.174988 \mathrm{E}+08$ & $0.691445 \mathrm{E}+02$ & $0.796074 \mathrm{E}-01$ & $0.176007 \mathrm{E}+05$ & $0.129190 \mathrm{E}+00$ \\
\hline $0.946426 \mathrm{E}+00$ & $0.178126 \mathrm{E}+08$ & $0.751785 \mathrm{E}+02$ & $0.738508 \mathrm{E}-01$ & $0.181595 \mathrm{E}+05$ & $0.123470 \mathrm{E}+00$ \\
\hline $0.946718 \mathrm{E}+00$ & $0.181208 \mathrm{E}+08$ & $0.816566 \mathrm{E}+02$ & $0.684406 \mathrm{E}-01$ & $0.186901 \mathrm{E}+05$ & $0.118080 \mathrm{E}+00$ \\
\hline $0.947008 \mathrm{E}+00$ & $0.184246 \mathrm{E}+08$ & $0.886351 \mathrm{E}+02$ & $0.633322 \mathrm{E}-01$ & $0.191899 \mathrm{E}+05$ & $0.112970 \mathrm{E}+00$ \\
\hline $0.947311 \mathrm{E}+00$ & $0.187274 \mathrm{E}+08$ & $0.962285 \mathrm{E}+02$ & $0.584727 \mathrm{E}-01$ & $0.196650 \mathrm{E}+05$ & $0.108080 \mathrm{E}+00$ \\
\hline $0.947616 \mathrm{E}+00$ & $0.190281 \mathrm{E}+08$ & $0.104482 \mathrm{E}+03$ & $0.538469 \mathrm{E}-01$ & $0.201019 \mathrm{E}+05$ & $0.103410 \mathrm{E}+00$ \\
\hline $0.969907 \mathrm{E}+00$ & $0.213201 \mathrm{E}+08$ & $0.175823 \mathrm{E}+03$ & $0.492332 \mathrm{E}-01$ & $0.316548 \mathrm{E}+05$ & $0.778400 \mathrm{E}-01$ \\
\hline $0.976431 \mathrm{E}+00$ & $0.223711 \mathrm{E}+08$ & $0.225820 \mathrm{E}+03$ & $0.453655 \mathrm{E}-01$ & $0.382388 \mathrm{E}+05$ & $0.678600 \mathrm{E}-01$ \\
\hline $0.972831 \mathrm{E}+00$ & $0.182476 \mathrm{E}+08$ & $0.806953 \mathrm{E}+02$ & $0.426301 \mathrm{E}-01$ & $0.197942 \mathrm{E}+05$ & $0.686400 \mathrm{E}-01$ \\
\hline $0.974626 \mathrm{E}+00$ & $0.186066 \mathrm{E}+08$ & $0.899448 \mathrm{E}+02$ & $0.403659 \mathrm{E}-01$ & $0.211497 \mathrm{E}+05$ & $0.647200 \mathrm{E}-01$ \\
\hline $0.976312 \mathrm{E}+00$ & $0.189660 \mathrm{E}+08$ & $0.100327 \mathrm{E}+03$ & $0.382072 \mathrm{E}-01$ & $0.226018 \mathrm{E}+05$ & $0.609900 \mathrm{E}-01$ \\
\hline $0.977900 \mathrm{E}+00$ & $0.193271 \mathrm{E}+08$ & $0.112038 \mathrm{E}+03$ & $0.361422 \mathrm{E}-01$ & $0.241644 \mathrm{E}+05$ & $0.574400 \mathrm{E}-01$ \\
\hline $0.979401 \mathrm{E}+00$ & $0.196910 \mathrm{E}+08$ & $0.125317 \mathrm{E}+03$ & $0.341603 \mathrm{E}-01$ & $0.258538 \mathrm{E}+05$ & $0.540600 \mathrm{E}-01$ \\
\hline $0.980824 \mathrm{E}+00$ & $0.200590 \mathrm{E}+08$ & $0.140464 \mathrm{E}+03$ & $0.322522 \mathrm{E}-01$ & $0.276894 \mathrm{E}+05$ & $0.508100 \mathrm{E}-01$ \\
\hline $0.982176 \mathrm{E}+00$ & $0.204325 \mathrm{E}+08$ & $0.157861 \mathrm{E}+03$ & $0.304089 \mathrm{E}-01$ & $0.296955 \mathrm{E}+05$ & $0.476900 \mathrm{E}-01$ \\
\hline
\end{tabular}




\section{DEVELOPMENT OF A HOLDUP CORRELATION}

\subsection{INTRODUCTION}

Duns and Ros (1963) suggest that the various flow regimes that accompany twophase flow in wells can be divided into three main regions depending on the gas throughput (Figure 3.1). The axes in Figure 3.1 denote the non-dimensional liquid and gas velocity numbers:

$$
\begin{aligned}
& \text { Liquid velocity number, } N_{l}=S_{l} v_{l}\left(\frac{\rho_{l} g}{\sigma}\right)^{0.25} \\
& \text { Gas velocity number, } N_{g}=S_{g} v_{g}\left(\frac{\rho_{g} g}{\sigma}\right)^{0.25}
\end{aligned}
$$

Here $v_{l}\left(v_{g}\right)$ is the liquid (gas) velocity, $S_{l}\left(S_{g}\right)$ is the in situ liquid (gas) volume fraction, $\rho_{l}\left(\rho_{g}\right)$ is the liquid (gas) density, $g$ is the acceleration due to gravity, and $\sigma$ is the surface tension. Region I has a continuous liquid phase, and contains the bubble flow, plug flow and part of the froth-flow regimes. Liquid and gas phases alternate in region II covering the slug flow and the remainder of the froth-flow regimes. Region III is characterized by a continuous gas phase, and contains the mist-flow regime.

Data from two-phase geothermal wells (see Section 2) are shown as diamonds in Figure 3.1. Although the geothermal data lie in all the three regions, the bulk of these data are contained in Region II. It appears from Figure 3.1 that relatively high liquid velocities characterize geothermal wells such that only froth-flow (regions I and II) and mist-flow (region III) are encountered in geothermal wells. Once the geothermal fluid starts flashing in the wellbore, the gas (and hence liquid) velocity increases rapidly. Thus, bubble flow, plug flow and slug flow regimes, if present at all, are likely to be confined to a narrow depth range and difficult to observe. Because of the limited range of flow regimes, it should be possible to describe two-phase flow in geothermal wells by a single (or at most a two-part) holdup correlation. 


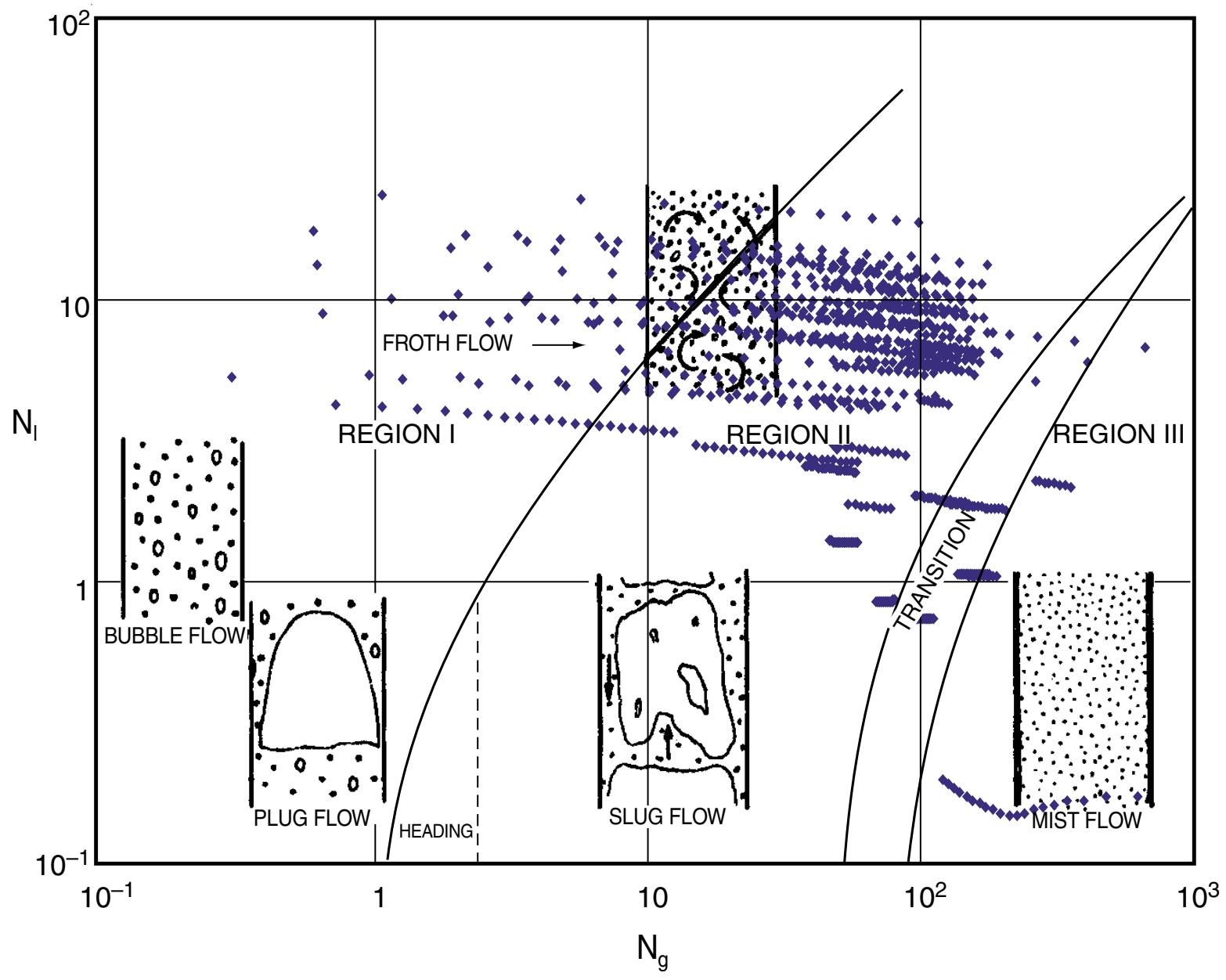

Figure 3.1. Two-phase fluid flow regimes according to Duns and Ros (1963). Also shown (as blue diamonds) are the data from geothermal boreholes (see Section 2). 


\subsection{HOLDUP CORRELATION PARAMETERS}

The flowing quality $Q_{f}$ (=gas flow rate/total flow rate) is defined as follows:

$$
Q_{f}=\frac{A S_{g} \rho_{g} v_{g}}{M}
$$

where $A$ is the internal cross-sectional area of the pipe, and $M$ is the total mass flow rate. Assuming a power law relationship for the velocity and in situ gas volume fraction, Bankoff (1960) derived a relation for flowing quality $Q_{f}$ that is equivalent to:

$$
Q_{f}=\frac{Q_{s}}{\left[1-Q_{s}\right] K+Q_{s}\left[1-\rho_{l}(1-K) / \rho_{g}\right]}
$$

where $Q_{s}$ is the in situ (or static) quality, $\rho_{m}$ is the mixture (gas plus liquid) density, and $K$ is a flow parameter (see below).

$$
\begin{gathered}
Q_{s}=\frac{S_{g} \rho_{g}}{\rho_{m}} \\
\rho_{m}=S_{l} \rho_{l}+S_{g} \rho_{g}
\end{gathered}
$$

For the case of homogeneous (i.e., no slip) flow, the in situ quality $Q_{s}$ is equal to the flowing quality $Q_{f}$; furthermore, the flow parameter $K$ is identically equal to unity. In general, one would expect the gas phase to rise more rapidly in the well than the liquid phase due to buoyancy; this implies that

$$
\begin{gathered}
Q_{f} \geq Q_{s} \\
S_{g} \leq K \leq 1
\end{gathered}
$$

The two-phase flow in a well is influenced by buoyancy, inertial, viscous and surface tension forces (Bankoff, 1960). Based on dimensional arguments, Hughmark (1962) concluded that the flow parameter $K$ might be expected to depend on the flowing liquid volume fraction $Y_{l}$, and Reynolds $(R n)$, Froude $(F r)$, and Weber $(W e)$ numbers. 


$$
\begin{aligned}
Y_{l} & =\frac{S_{l} v_{l}}{\left(S_{l} v_{l}+S_{g} v_{g}\right)} \\
R n & =\frac{d_{w} M}{A \mu_{m}} \\
F r & =\frac{M^{2}}{\left(d_{w} A^{2} g \rho_{m}^{2}\right)} \\
W e & =\frac{d_{w}^{2} g \rho_{g} F r}{\sigma}
\end{aligned}
$$

Here $d_{w}$ is the inside well diameter, $\sigma$ is the liquid surface tension, and $\mu_{m}$ is the mixture viscosity.

$$
\mu_{m}=S_{l} \mu_{l}+S_{g} \mu_{g}
$$

In Equation (3.7), $\mu_{l}\left(\mu_{g}\right)$ denotes the liquid (gas) viscosity.

Mixture (liquid plus gas) density $\rho_{m}$ and mixture viscosity $\mu_{m}$ can be defined in a number of ways (see e.g. Hughmark, 1962; Dukler, et al., 1964); in the following, the expressions given by Hughmark, Equations (3.4) and (3.7), will be used. These definitions for $\rho_{m}$ and $\mu_{m}$ are different than those used by Dukler, et al. (1964; see Appendix A). In a preliminary investigation (Garg et al., 2003), the authors formulated a holdup correlation using Dukler et al.'s definitions for $\rho_{m}$ and $\mu_{m}$. Subsequent numerical experiments showed that the latter correlation constitutes a highly implicit and non-linear relation for flow parameter $K$, and a solution is not possible in many cases. It was therefore decided to adopt Hughmark's definitions for $\rho_{m}$ and $\mu_{m}$ which result in a better-behaved relation for $K$.

\subsection{HOLDUP CORRELATION}

To find a correlation for $K$, it is assumed that $K$ can be expressed as a function of a single variable $Z$ :

$$
K=K\left(Z\left(R n, F r, Y_{l}, W e, S_{l}\right)\right)
$$

Hughmark (1962) investigated the dependence of $Z$ on $R n, F r, Y_{l}$, and $W e$, and found that $Z$ (and hence $K$ ) did not appreciably depend on the Weber number $(W e$ ). The authors have independently confirmed this result using data for geothermal wells (Section 2). Consequently, $Z$ is assumed to depend on only four variables, i.e., $R n, F r, Y_{l}$ and $S_{l}$; note that Hughmark (1962) did not account for the dependence of $Z$ on $S_{l}$. Following Hughmark (1962), we introduce a particularly simple relationship for $Z$ :

$$
Z=R n^{\alpha} F r^{\beta} Y_{l}^{\gamma} S_{l}^{\omega}
$$


where $\alpha, \beta, \gamma$, and $\omega$ are as yet undetermined constants. Determination of the exponents in Equation (3.9) is straightforward when the functional relationship between $K$ and $Z$ is known; in this case, exponents can be estimated by minimizing the variance between the calculated (i.e., from the functional relationship $K-Z$ ) and measured (i.e., those derived from fitting the flow data) values for $K$. Unfortunately, the functional relationship $K(Z)$ is unknown, and must be determined from the dataset.

To determine the exponents in Equation (3.9), we introduce a nonparametric measure of variation. Given a candidate set of exponents, we calculate $Z$ for each point in the dataset for geothermal wells (Section 2, and Figure 3.1). Next, we sort the dataset in order of increasing $Z$, and calculate a pseudo-variance $S . V$. as follows:

$$
\text { S.V. }=\sum_{i=1}^{n-1}\left(K_{i+1}-K_{i}\right)^{2}
$$

Here $K_{i}$ denotes the value of $K$ corresponding to $Z_{i}, n$ is the number of points in the dataset, and $Z_{n}$ is the largest value of $Z$. The exponents in Equation (3.9) are obtained by minimizing this pseudo-variance.

Since a set of exponents may be multiplied by an arbitrary non-zero constant without changing the order of the sequence of $K$ 's, only three (3) of the exponents need to be varied when minimizing the pseudo-variance. Note that very small changes in the exponents can leave the order of the sequence of $K$ 's unchanged and that when the order of the sequence is changed, the S.V. jumps discontinuously. Such functional behavior rules out the use of gradient methods for finding a minimum. The downhill simplex method (Press, et al., 1992) is a procedure for finding minima of multidimensional functions that does not make use of derivatives, making it well suited to the present effort. A set of exponents for starting the procedure was obtained by assuming that $\log (K)$ is a linear function of $\log (Z)$ (and hence of $\log R n, \log F r, \log Y_{l}$, and $\log S_{l}$ ), and using the least squares method to determine an initial set of coefficients $(\alpha, \beta, \gamma$, and $\omega)$. The downhill simplex method finds smaller and smaller values for the $S . V$. until a region is reached which appears to be a broad local minimum. Since there is no reason to believe that this procedure yields a global minimum, various other sets of starting exponents were tried. While the downhill simplex method failed for some starting sets, it worked for a number of others. The function $K(Z)$ was found to be monotonic in all cases, but with varying sign. By simply multiplying all the exponents in a set by -1 , the order of the sequence of $K$ 's is inverted, giving the same $S . V$. and a graph with a slope of the opposite sign.

Changing the sign of the various exponents as needed to ensure that the exponent of the flowing liquid volume fraction is negative, and plotting $K$ versus $Z$, it was found that the graphs always looked like a hyperbola with $K=1$ as an asymptote (see e.g. Figure 3.2). Although a hyperbola for $K(Z)$ can be made to yield a pseudo-variance that is close to the minimum, a more general functional form for $K(Z)$ is needed in order to improve the fit in regions of $Z$ that make little contribution to the pseudo-variance. 


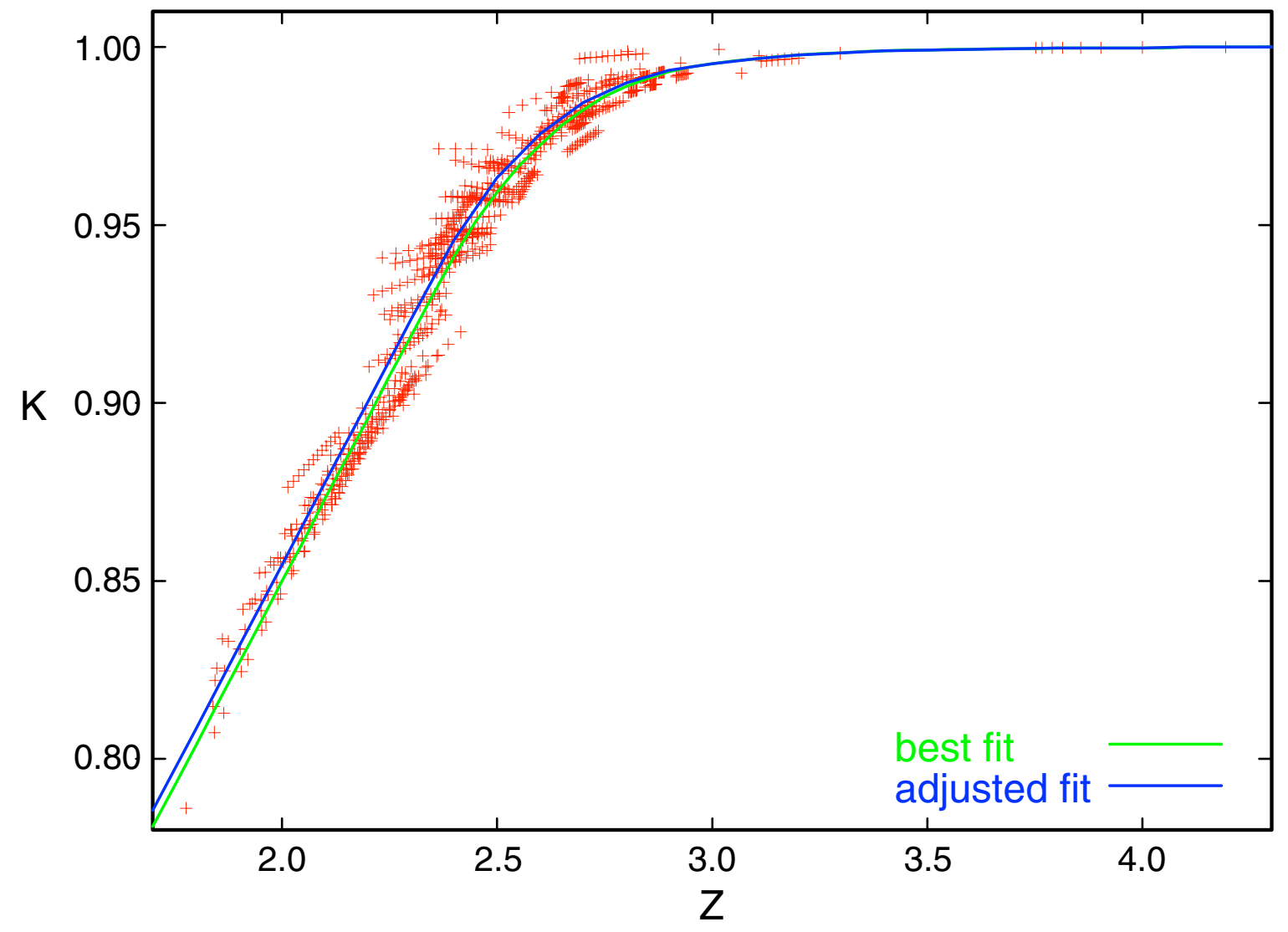

Figure 3.2. A plot of $K$ versus $Z$. Data points (+), i.e., $K$ versus $Z$ values, in the figure were obtained by minimizing the pseudo-variance. $Z$ is defined by Equation (3.9) with $\alpha=\mathbf{0 . 0 3 8 8 8 8 7}, \beta=0.0065170, \gamma=-0.0002960$, and $\omega=$ -0.1 . The green line denotes the best fit to the $K-Z$ data. The blue line was obtained by making slight modifications to the green line (see text). 


\subsection{VALIDATION OF HOLDUP CORRELATION}

To verify that the holdup correlation (i.e., $K(Z)$ relationship) developed in the preceding section can be used to simulate two-phase flow in geothermal wells, a special version of WELBOR code was created; this version was configured to use the $K(Z)$ relation (green line) shown in Figure 3.2. The latter version of WELBOR was employed to simulate flow data for all the wells in the dataset. Except for the holdup correlation, these simulations utilized the parameters (Appendix B) used in the calculations described in Section 2.

The computed results for wellhead pressure for all the high mass velocity (mass velocity $=$ total discharge rate $/$ pipe cross-sectional area $>687 \mathrm{~kg} / \mathrm{s}-\mathrm{m}^{2}$; the low mass velocity profiles are considered separately in Section 3.5) profiles are compared with data (i.e., wellhead pressures computed by matching downhole pressure profiles in Section 2) in Table 3.1. The computed wellhead pressures using the best-fit relation for $K(Z)$ were found (on average) to be a little on the low side. The observation that the computed pressures are lower than the measured values suggests that the "best-fit" correlation for $K(Z)$ over-predicts the slip between the liquid and gas phases. Stated somewhat differently, the correlation yields too low values for $K$. It was, therefore, decided to modify the correlation for $K(Z)$; the modified correlation is shown as the blue curve in Figure 3.2. The modified $K(Z)$ fit yields satisfactory agreement between data and computed wellhead pressures (Table 3.1); the rootmean-square error is only 0.67 bars.

It is apparent from Table 3.1 that the above-derived correlation for $K(Z)$ leads to choking for three pressure profiles (KE1-4a, KE1-4b, KE1-19Sa). Well KE1-4 is a slim hole (internal diameter $=10.2 \mathrm{~cm}$ ), and the downhole profiles were recorded during a short-term discharge test. As remarked in Section 2, the nominal discharge rates for KE1-4 $(7.08 \mathrm{~kg} / \mathrm{s}$ on November 12, 1983, and $8.44 \mathrm{~kg} / \mathrm{s}$ on November 13, 1983) may be in substantial error. The modified $K(Z)$ fit implies that the maximum discharge rate for KE1-4 is around $6.9 \mathrm{~kg} / \mathrm{s}$, which is within the likely error band for the nominal discharge rate for KE1-4. For KE119Sa, the computed value for the maximum discharge rate $(23.0 \mathrm{~kg} / \mathrm{s})$ is within $4 \%$ of the nominal discharge rate $(23.9 \mathrm{~kg} / \mathrm{s})$. Thus, it can be concluded that the modified $K(Z)$ fit gives acceptable results for these three profiles as well.

As mentioned above, downhole pressure profiles for all the high mass velocity cases in the dataset (Table 3.1) were simulated using the modified correlation for $K(Z)$. The latter computed profiles are compared with (1) measurements, and (2) calculated profile (bestmatch) using an adjustable holdup correlation (Section 2). In most cases, the agreement is quite good (see Appendix C). A typical example (well A-4) is shown in Figure 3.3; the computed pressure profile for well A-4, shown as a dashed line in Figure 3.3, is in excellent agreement with the measurements. 
Table 3.1. Comparison of wellhead pressures for high mass velocity profiles (mass velocity $>687 \mathrm{~kg} / \mathrm{s}-\mathrm{m}^{2}$ ) computed using (1) best fit correlation for $K(Z)$, and (2) modified correlation for $K(Z)$ with data.

\begin{tabular}{|c|c|c|c|c|}
\hline Well & $P$-data & $\begin{array}{l}P \text {-comp } \\
\text { (best fit) }\end{array}$ & $\begin{array}{c}P \text {-comp } \\
\text { (modified fit) }\end{array}$ & $\delta P^{* * *}$ \\
\hline A-1 & 8.94 & 9.14 & 9.51 & -0.57 \\
\hline$A-2$ & 8.78 & 8.83 & 9.22 & -0.44 \\
\hline A-4 & 10.53 & 10.35 & 10.75 & -0.22 \\
\hline A-6 & 14.70 & 14.74 & 15.15 & -0.45 \\
\hline A-7 & 12.85 & 10.81 & 11.23 & 1.62 \\
\hline A-8 & 9.75 & 9.17 & 9.66 & 0.09 \\
\hline A-9 & 14.56 & 13.75 & 14.17 & 0.39 \\
\hline A-10 & 11.39 & 10.17 & 10.59 & 0.80 \\
\hline A-11 & 11.16 & 11.36 & 11.79 & -0.63 \\
\hline A-12 & 12.14 & 11.72 & 12.12 & 0.02 \\
\hline A-13 & 12.18 & 11.42 & 11.79 & 0.39 \\
\hline A-14 & 10.98 & 10.44 & 10.86 & 0.12 \\
\hline A-16 & 10.36 & 10.39 & 10.89 & -0.53 \\
\hline A-19 & 9.61 & 9.16 & 9.59 & 0.02 \\
\hline A-20 & 10.12 & 9.81 & 10.26 & -0.14 \\
\hline A-21 & 10.52 & 9.31 & 9.77 & 0.75 \\
\hline B-5 & 10.97 & 9.64 & 10.26 & 0.71 \\
\hline C-6 & 9.55 & 6.81 & 7.68 & 1.87 \\
\hline KE1-4a & 4.26 & Choke@26.0m & Choke@3.7m* & NA \\
\hline $\mathrm{KE} 1-4 \mathrm{~b}$ & 3.98 & Choke@108.1m & Choke@88.9m & NA \\
\hline KE1-17a & 6.64 & 6.67 & 7.11 & -0.47 \\
\hline KE1-19Sa & 3.53 & Choke@30.3m & Choke@7.6m** & NA \\
\hline KE1-19Sb & 6.37 & 6.18 & 6.61 & -0.24 \\
\hline KE1-22b & 7.37 & 7.79 & 8.15 & -0.78 \\
\hline GH-11a & 12.23 & 11.90 & 12.12 & 0.11 \\
\hline GH-11b & 10.51 & 9.79 & 10.10 & 0.41 \\
\hline GH-20a & 14.14 & 14.37 & 14.56 & -0.42 \\
\hline GH-20b & 13.02 & 13.38 & 13.59 & -0.57 \\
\hline GH-20c & 11.70 & 12.19 & 12.43 & -0.73 \\
\hline \multicolumn{4}{|c|}{ Total (26 profiles) } & 1.11 \\
\hline
\end{tabular}




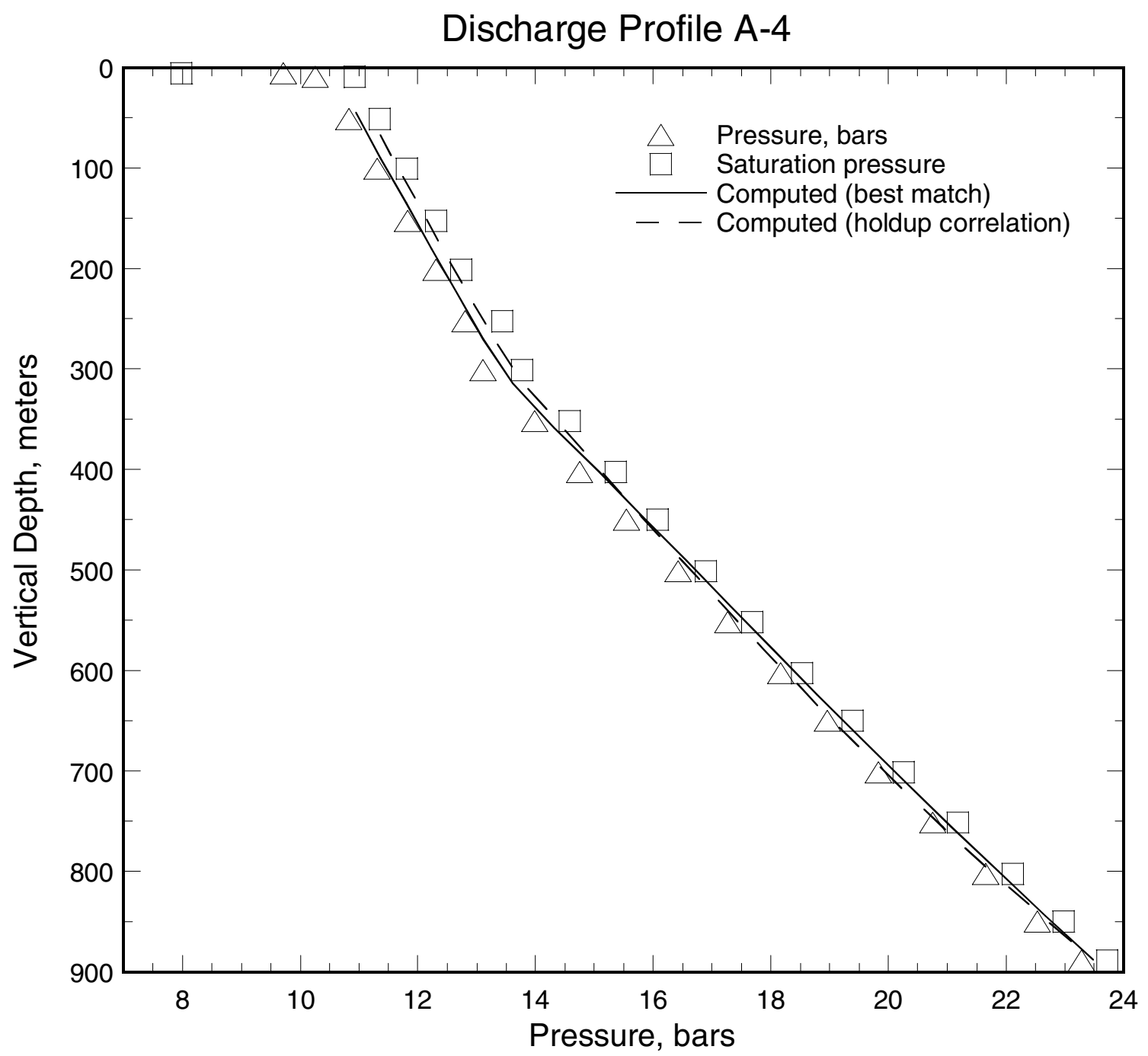

Figure 3.3. Pressure profile (triangle) recorded in discharging well A-4. The square indicates saturation pressure corresponding to the local measured temperature. The solid line is the computed pressure profile using an adjustable holdup correlation (see Section 2 for details). The computed pressure profile using the modified correlation for $K(Z)$ is shown as a dashed line. 


\subsection{HOLDUP CORRELATION FOR LOW MASS VELOCITY}

The modified correlation was found to yield satisfactory results for all the high mass velocity (mass velocity $>687 \mathrm{~kg} / \mathrm{s}-\mathrm{m}^{2}$ ) profiles in the dataset. The computed pressures for low mass velocity (mass velocity $<650 \mathrm{~kg} / \mathrm{s}-\mathrm{m}^{2}$ ) profiles are, however, too high, and imply that the correlation for $K(Z)$ would need to further modified for low mass velocity. Attempts to develop a single correlation for both the high and low mass velocity cases by including an additional variable (i.e., mass velocity) in the relation for $Z$ (Equation 3.9) were unsuccessful. Accordingly, it was decided to consider the low mass velocity profiles separately. The $K(Z)$ correlation for the latter case is shown in Figure 3.4. To minimize the deviation between data and the computed wellhead pressures, it was found necessary to slightly adjust the best-fit correlation (see Figure 3.4).

The computed results for wellhead pressure for all the low mass velocity (mass velocity $=$ total discharge rate $/$ pipe cross-sectional area $<650 \mathrm{~kg} / \mathrm{s}-\mathrm{m}^{2}$.) profiles are compared with data (i.e., wellhead pressures computed by matching downhole pressure profiles in Section 2) in Table 3.2. The computed wellhead pressures using the best-fit relation for $K$ (green line, Figure 3.4) were found (on average) to be a little on the low side. The modified $K(Z)$ fit (blue line, Figure 3.4), however, yields satisfactory agreement between data and computed wellhead pressures (Table 3.2 ); the root-mean-square error is 0.73 bars.

As for the high mass velocity cases, the downhole pressure profiles for all the low mass velocity cases in the dataset (Table 3.2) were simulated using the modified correlation for $K$ (blue line, Figure 3.4). The latter computed profiles are compared with (1) measurements, and (2) calculated profile (best-match) using an adjustable holdup correlation (Section 2). In most cases, the agreement is good (see Appendix C).

\subsection{COMPARISON WITH SPINNER DATA}

The rotational speed of a spinner is proportional to the mass-averaged velocity of the fluid mixture passing through the spinner. Except for annular flow, the mass-averaged velocity indicated by the spinner should correspond closely to the mass-averaged velocity of the entire flow stream (Gang, et al., 1990). The spinner response $f$ is related to mass-averaged fluid velocity $v_{m}$ and cable speed $v_{c}$ as follows:

$$
f=m\left(v_{m}-v_{c}\right)+c
$$

where $m$ and $c$ are the calibration constants. Note that the spinner does not rotate for a small range of relative fluid velocities, $v_{m}-v_{c}$, in either the upward or the downward logging direction. The smallest value of $\left|v_{m}-v_{c}\right|$ at which spinner rotation begins is called the threshold velocity $v_{t h}$.

$$
v_{t h}=-\frac{c}{m}
$$




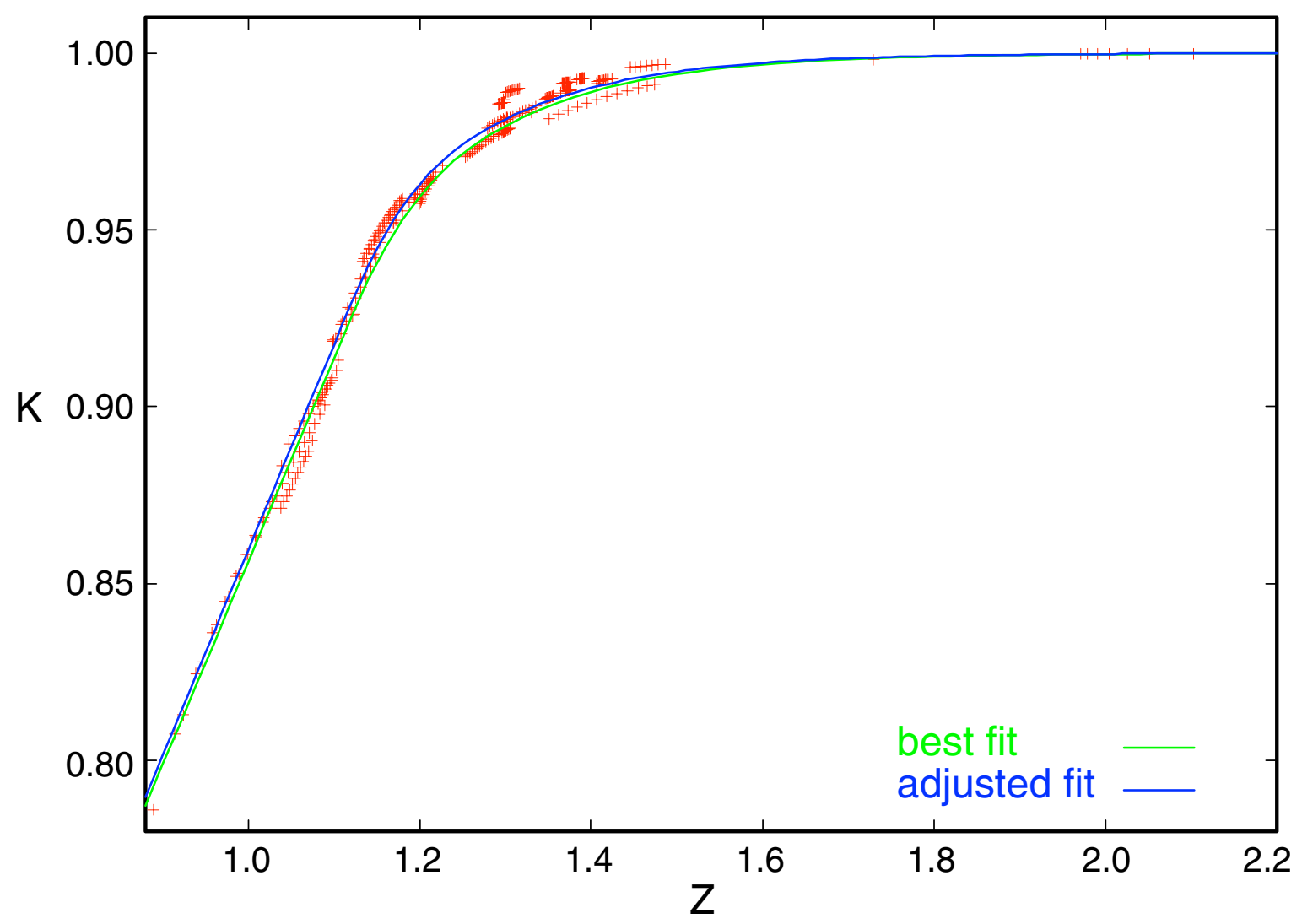

Figure 3.4. A plot of $K$ versus $Z$ for low mass velocity (mass velocity $<650 \mathrm{~kg} / \mathrm{s}-\mathrm{m}^{2}$ ) profiles. Data points $(+)$, i.e., $K$ versus $Z$ values, in the figure were obtained by minimizing the pseudo-variance. $Z$ is defined by Equation (3.9) with $\alpha=-0.009546812, \beta=0.00975959, \gamma=-0.000149868$, and $\omega=-0.1$.The green line denotes the best fit to the $K-Z$ data. The blue line was obtained by making slight modifications to the green line (see text). 
Table 3.2. Comparison of wellhead pressures for low mass velocity profiles (mass velocity $<650 \mathrm{~kg} / \mathrm{s}-\mathrm{m}^{2}$ ) computed using (1) best fit correlation for $K(Z)$, and (2) modified correlation for $K(Z)$ with data.

\begin{tabular}{|c|c|c|c|c|}
\hline Well & $P$-data & $\begin{array}{l}P \text {-comp } \\
\text { (best fit) }\end{array}$ & $\begin{array}{l}P \text {-comp } \\
\text { (mod fit) }\end{array}$ & $\delta P^{* *}$ \\
\hline A-18 & 8.19 & No Solution* & 8.99 & -0.80 \\
\hline C-1 & 10.35 & 9.89 & 10.35 & 0.00 \\
\hline $\mathrm{C}-2$ & 11.58 & 11.41 & 11.69 & -0.11 \\
\hline $\mathrm{C}-3$ & 11.74 & 10.27 & 10.92 & 0.82 \\
\hline $\mathrm{C}-4$ & 12.43 & 11.66 & 12.15 & 0.28 \\
\hline C-5 & 13.88 & 13.78 & 14.64 & -0.76 \\
\hline B-3 & 16.27 & 16.04 & 16.70 & -0.43 \\
\hline B-4 & 18.70 & 17.10 & 17.96 & 0.74 \\
\hline B-13 & 11.76 & 9.77 & 10.57 & 1.19 \\
\hline KE1-9 & 8.59 & 8.27 & 8.74 & -0.15 \\
\hline KE1-11 & 18.66 & 17.10 & 17.29 & 1.37 \\
\hline KE1-17b & 7.11 & 7.08 & 7.38 & -0.27 \\
\hline KE1-22a & 7.82 & 7.98 & 8.22 & -0.40 \\
\hline S-2 & 1.15 & 2.45 & 2.50 & -1.35 \\
\hline CS-1 & 3.97 & 3.31 & 4.06 & -0.09 \\
\hline \multicolumn{4}{|c|}{ Total (15 profiles) } & 0.04 \\
\hline
\end{tabular}

The mass-averaged mixture velocity $v_{m}$ can be computed from the in situ liquid and vapor saturations, densities, and velocities.

$$
v_{m}=\frac{\left(\rho_{l} S_{l} v_{l}+\rho_{g} S_{g} v_{g}\right)}{\left(\rho_{l} S_{l}+\rho_{g} S_{g}\right)}
$$

In geothermal wells, the liquid (i.e. water) density is much greater than the vapor (i.e. steam) density; this means that the mass-averaged mixture velocity is a strong function of the in situ liquid volume fraction $S_{l}$. Thus matching the spinner data can provide an independent check on the holdup correlations developed in Sections 3.3-3.5.

Comparison of spinner data with the computed fluid velocity requires a certain amount of care. Spinner data are often quite noisy in two-phase flow, and must be smoothed for a meaningful comparison. In this work, a rather simple procedure was adopted to smooth the spinner data. A running average of 11 (or 21 in the case of extremely noisy data) data points was used to compute the smoothed spinner response. Spinner surveys often display anomalous response (e.g. a decrease or no change in rotation rate as the spinner tool is traversed up or down the hole, or a less than commensurate change in rotation rate at a 
discontinuous change in well diameter) due to improper centering of the tool in the well or a possible temporary flow obstruction in the spinner tool. Obviously, such spinner data must be discarded.

The smoothed spinner data for well A-4 are compared with the computed spinner response in Figure 3.5. The mass-averaged velocity was computed using the "high mass velocity" correlation developed in Section 3.4 (see also Figure 3.3 for a comparison of the computed pressure profile with the measurements). A least-squares procedure was employed to evaluate the calibration constants in Equation (3.11), and thereby relate the smoothed spinner response to the computed mass-averaged velocity. The spinner data for well A-4 (Figure 3.5) exhibit an anomalous response (decrease/no change in the rotation rate) in the depth range $0-150 \mathrm{~m}$. As can be seen from Figure 3.5, except for the depth range 0-150 m, the smoothed spinner response shows a good agreement with the computed curve. Similar results for all the other wells with spinner data are displayed in Appendix D. Barring very few exceptions; the spinner measurements are in good agreement with the computed response (Appendix D and Table 3.3). Thus, taken as a whole, the spinner measurements tend to validate the holdup correlations developed in Sections 3.3-3.5.

\subsection{FORTRAN SUBROUTINES}

The holdup correlations described in Sections 3.3-3.5 have been incorporated into three Fortran subroutines (holdfk; hldfn1; hldfn2) listed in Appendix E Subroutine holdfk is designed to compute flow parameter $K$ and its derivative with respect to the flowing quality $Q_{f}$; holdfk in turn calls subroutines hldfn1 (for mass velocities $>687 \mathrm{~kg} / \mathrm{s}-\mathrm{m}^{2}$ ) and hldfn2 (for mass velocities $\left.<650 \mathrm{~kg} / \mathrm{s}-\mathrm{m}^{2}\right)$. In the transition region $\left(650 \mathrm{~kg} / \mathrm{s}-\mathrm{m}^{2}<\right.$ mass velocity $<687 \mathrm{~kg} / \mathrm{s}^{-\mathrm{m}^{2}}$ ), a linear interpolation is used to evaluate $K$ and its derivative w.r.t. $Q_{f}$. The Fortran subroutines given in Appendix E may be used in conjunction with any wellbore simulator. The authors have included the latter subroutines in a special version of WELBOR code. To illustrate the use of the WELBOR code (including the holdup correlations developed herein) to simulate the downhole pressure/temperature surveys and the wellhead discharge data (i.e., discharge rate versus wellhead pressure data), an example is given in the following subsection.

\subsection{AN EXAMPLE}

Slimhole SNLG87-29 (Finger et al., 1999) is completed with a 4.5-inch casing (102 mm internal diameter) to a depth of $159.7 \mathrm{~m}$; an open hole (99 mm internal diameter) completion is used below the latter depth. PTS surveys in the discharging borehole show that the principal feedzone is located at a depth of $248.4 \mathrm{~m}$. Four (4) brief discharge tests were performed during August and September 1993. A pressure survey taken about an hour after the initiation of discharge on August 5, 1993 is shown in Figure 3.6. The saturation pressures corresponding to the temperature survey are also displayed in Figure 3.6. It is apparent from Figure 3.6 that liquid conditions prevail in the wellbore below a depth of $\sim 100$ meters. The 


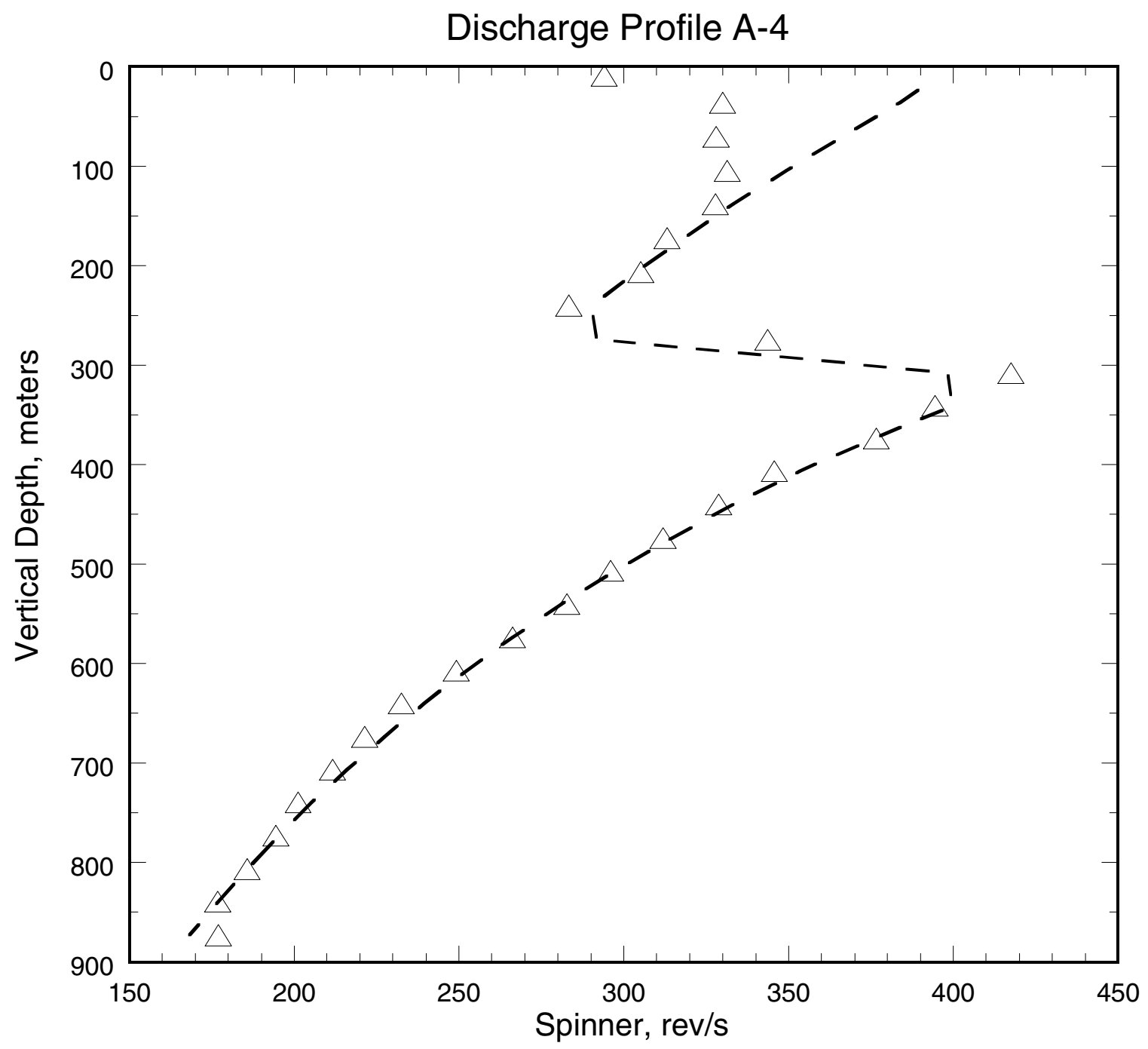

Figure 3.5. Comparison of the smoothed spinner response (triangles) with the computed spinner response (dashed line) for well A-4. 
Table 3.3. Comparison of the smoothed spinner response with the computed response for wells in the dataset.

\begin{tabular}{|c|c|}
\hline $\begin{array}{l}\text { Well } \\
\text { Name }\end{array}$ & Comments \\
\hline A-1 & Good fit \\
\hline A-2 & Good fit \\
\hline A-4 & $\begin{array}{l}\text { Spinner data shows no change in spinner rotation rate in depth range } 0-100 \mathrm{~m} \text { and is not } \\
\text { reliable. Good fit to spinner data below } 100 \mathrm{~m} \text {. }\end{array}$ \\
\hline A-6 & $\begin{array}{l}\text { Spinner data shows no change or decrease in rotation rate in depth range } 0-200 \mathrm{~m} \text { and is } \\
\text { not reliable. Good fit to spinner data below } 200 \mathrm{~m} \text {. }\end{array}$ \\
\hline A-7 & $\begin{array}{l}\text { Spinner data shows no change in rotation rate in depth range } 0-80 \mathrm{~m} \text {. Good fit to spinner } \\
\text { data below } 80 \mathrm{~m} \text {. }\end{array}$ \\
\hline A-8 & $\begin{array}{l}\text { Spinner data shows no change in rotation rate in depth range } 250-500 \mathrm{~m} \text {. Good fit to other } \\
\text { spinner data. }\end{array}$ \\
\hline A-9 & Spinner data unreliable in depth range $0-50 \mathrm{~m}$. Good fit to spinner data below $50 \mathrm{~m}$. \\
\hline A-10 & Good fit. \\
\hline A-11 & $\begin{array}{l}\text { Spinner data shows a decrease in rotation rate in depth range } 0-30 \mathrm{~m} \text {. Good fit to spinner } \\
\text { data below } 30 \mathrm{~m} \text {. }\end{array}$ \\
\hline A-12 & Spinner data unreliable in depth range $0-10 \mathrm{~m}$. Good fit to spinner data below $10 \mathrm{~m}$. \\
\hline A-13 & Spinner data extremely noisy in depth range $360-430 \mathrm{~m}$ and below $970 \mathrm{~m}$. Fair fit. \\
\hline A-14 & Spinner data unreliable in depth range $0-20 \mathrm{~m}$. Good fit to spinner data below $20 \mathrm{~m}$. \\
\hline A-16 & $\begin{array}{l}\text { Good fit to spinner data in the upper large-diameter }(384 \mathrm{~mm}) \text { part of the well. Poor fit to } \\
\text { spinner data in the } 315 \mathrm{~mm} \text { section. }\end{array}$ \\
\hline A-18 & $\begin{array}{l}\text { Poor spinner data in depth range } 0-100 \mathrm{~m} \text {, and below } 400 \mathrm{~m} \text { (inconsistent change in } \\
\text { rotation rate). Poor fit. }\end{array}$ \\
\hline A-19 & Good fit. \\
\hline A-20 & Good fit. \\
\hline A-21 & $\begin{array}{l}\text { Spinner response anomalous in depth interval } 450-520 \mathrm{~m} \text { (no change in rotation rate). Fair } \\
\text { fit to other spinner data. }\end{array}$ \\
\hline
\end{tabular}


Table 3.3. Comparison of the smoothed spinner response with the computed response for wells in the dataset (concl).

\begin{tabular}{|c|c|}
\hline $\begin{array}{l}\text { Well } \\
\text { Name }\end{array}$ & Comments \\
\hline B-3 & $\begin{array}{l}\text { Spinner response very noisy in } 221 \mathrm{~mm} \text { portion. Smoothed spinner data does not show } \\
\text { much change in rotation rate between } 221 \mathrm{~mm} \text { and } 315 \mathrm{~mm} \text { sections. Good fit to spinner } \\
\text { data in } 315 \mathrm{~mm} \text { section. }\end{array}$ \\
\hline B-4 & Good fit. \\
\hline B-5 & $\begin{array}{l}\text { Spinner survey shows a reduction in gradient at } \sim 500 \mathrm{~m} \text {; no indication in corresponding } \\
\text { pressure/temperature data. Good fit to spinner data above } 500 \mathrm{~m} \text {. }\end{array}$ \\
\hline B-13 & $\begin{array}{l}\text { Spinner survey shows an offset at } 500-600 \mathrm{~m} \text {; no such indication in pressure/temperature } \\
\text { data. Good fit to spinner data above } 500 \mathrm{~m} \text {. }\end{array}$ \\
\hline $\mathrm{C}-1$ & Good fit. \\
\hline $\mathrm{C}-2$ & $\begin{array}{l}\text { Spinner data anomalous from } 0-100 \mathrm{~m} \text { and from } 250-350 \mathrm{~m} \text {. Good fit to other spinner } \\
\text { data. }\end{array}$ \\
\hline $\mathrm{C}-3$ & Good fit. \\
\hline $\mathrm{C}-4$ & $\begin{array}{l}\text { Spinner rotation rate anomalous (slow increase } 0-300 \mathrm{~m} \text {, fast increase } 300-530 \mathrm{~m} \text {, } \\
\text { constant } 530-650 \mathrm{~m} \text {, fast increase below } 650 \mathrm{~m} \text { ); no indication of such behavior in } \\
\text { pressure/temperature data. Poor fit. }\end{array}$ \\
\hline$C-5$ & $\begin{array}{l}\text { Spinner rotation rate anomalous below } 400 \mathrm{~m} \text { (fast increase } 400-500 \mathrm{~m} \text {, essentially } \\
\text { constant } 500-800 \mathrm{~m} \text { ); no indication of such behavior in pressure/temperature data. Good } \\
\text { fit to spinner data above } 400 \mathrm{~m} \text {. }\end{array}$ \\
\hline C-6 & $\begin{array}{l}\text { Spinner survey shows an increase in gradient at } \sim 300 \mathrm{~m} \text {; no such indication in } \\
\text { pressure/temperature data. Good fit to spinner data below } 300 \mathrm{~m} \text {. }\end{array}$ \\
\hline CS-1 & $\begin{array}{l}\text { Spinner data very noisy. Smoothed data show little variation in rotation rate below } \\
\sim 320 \mathrm{~m} \text {; no such indication in pressure/temperature data. Good fit to data above } 320 \mathrm{~m} \text {. }\end{array}$ \\
\hline GH-11 & $\begin{array}{l}\text { Spinner rotation rate shows a discontinuous jump at } \sim 100 \mathrm{~m} \text {. Good fit to spinner data } \\
\text { below } 100 \mathrm{~m} \text {. }\end{array}$ \\
\hline
\end{tabular}




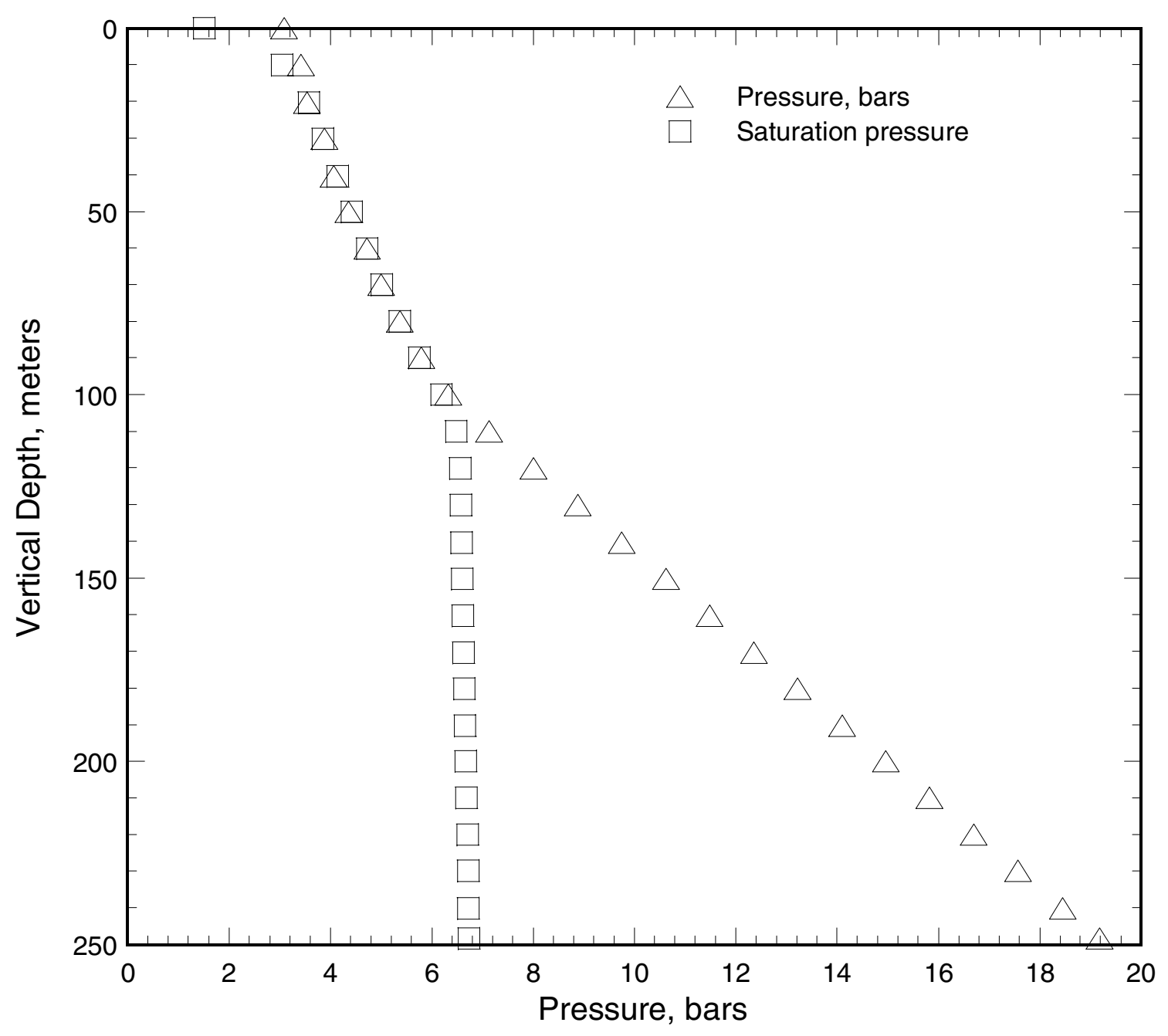

Figure 3.6. A pressure survey (triangle) recorded in slimhole SNLG87-29 on August 5, 1993. Also shown is the saturation pressure profile (square) corresponding to the temperature survey. 
close agreement between the measured and saturation pressures over the depth interval 20 to 100 meters indicates that the downhole pressure/temperature data are consistent. Divergence between the measured and saturation pressures above 20 meters is believed to be due to a possible malfunctioning of the temperature gauge since the temperature (and hence saturation pressure) drop off above 20 meters observed on August 5, 1993 was not seen in any of the later temperature surveys. Based on downhole pressure measurements (Finger et al., 1999), it can be concluded that the productivity index for SNLG87-29 is, for all practical purposes, infinite ( $>400 \mathrm{~kg} / \mathrm{s}-\mathrm{bar}$ ); this implies that the flowing feedzone pressure is essentially independent of the discharge rate.

To match the pressure and temperature profiles recorded on August 5, 1993, the following well geometry is assumed for slimhole SNLG87-29:

\begin{tabular}{|c|c|c|c|}
\hline $\begin{array}{c}\text { Measured } \\
\text { Depth } \\
\text { (meters) }\end{array}$ & $\begin{array}{c}\text { Vertical } \\
\text { Depth } \\
\text { (meters) }\end{array}$ & $\begin{array}{c}\text { Angle with } \\
\text { Vertical } \\
\text { (Degrees) }\end{array}$ & $\begin{array}{c}\text { Internal } \\
\text { Diameter } \\
(\mathrm{mm})\end{array}$ \\
\hline $0-159.7$ & $0-159.7$ & 0.000 & 102 \\
$159.7-248.4$ & $159.7-248.4$ & 0.000 & 99 \\
\hline
\end{tabular}

A pressure of $\sim 19.18$ bars was recorded in the flowing well at $248.4 \mathrm{mTVD}$; the corresponding temperature was $163.48^{\circ} \mathrm{C}$. The reported discharge rate was $7.1 \mathrm{~kg} / \mathrm{s}$. In the absence of data on the chemical composition of the produced fluids, the reservoir fluid is assumed to be pure water.

The stable formation temperature, as recorded in a downhole survey in the shut-in borehole, was approximated by the following temperature distribution using linear interpolations between tabulated data.

\begin{tabular}{|c|c|}
\hline $\begin{array}{c}\text { Vertical Depth } \\
\text { (meters) }\end{array}$ & $\begin{array}{c}\text { Temperature } \\
\text { (Degrees Celsius) }\end{array}$ \\
\hline 0 & 22 \\
25 & 76 \\
100 & 149 \\
200 & 162 \\
250 & 163.5 \\
\hline
\end{tabular}

To match the measured temperature distribution below 100 meters (i.e., in the single phase liquid portion), it was found necessary to use a rather high value $\left(30 \mathrm{~W} / \mathrm{m}-{ }^{\circ} \mathrm{C}\right)$ for the effective thermal conductivity, $K$. This is really not surprising in that the temperature profile was taken about 1 hour after the initiation of discharge. Heat losses from the borehole to the formation are treated using a steady-flow model in the WELBOR code. The difficulty is that at early times, the steady-flow model is inappropriate, and the heat transfer is augmented. As remarked by Pritchett (1993), the transient case may be treated as a succession of states in which the effective thermal conductivity is a decreasing function of time, which reaches the steady-state value only at infinite time. 
The computed pressure and temperature profiles are compared with the measurements in Figures 3.7 and 3.8, respectively. Simulated results (Figures 3.7 and 3.8) are shown for two different roughness factors:

(i) Roughness factor, $\varepsilon=0.000 \mathrm{~mm}$ for all depths

(ii) Roughness factor, $\varepsilon=0.125 \mathrm{~mm}$ for depths $<159.7 \mathrm{~m}$

$$
=0.000 \mathrm{~mm} \text { for depths }>159.7 \mathrm{~m}
$$

It is apparent from Figures 3.7 and 3.8 that the pressure and temperature profiles computed using the smooth pipe assumption are indistinguishable from those for a rough pipe for depths greater than 80 meters. At shallower depths (depth $<80 \mathrm{~m}$ ), a non-zero roughness factor is required to provide a good match between the measurements and the computed profiles.

The model parameters (effective thermal conductivity, roughness factor) inferred from a match to the downhole pressure and temperature surveys (Figures 3.7 and 3.8) were used to compute the characteristic curve (i.e., mass discharge rate versus wellhead pressure) for SNLG87-29. The computed values are compared with the measurements in Figure 3.9; the agreement is very good. It is apparent from Figure 3.9 that the theoretical curve has a discontinuity in slope at about a discharge rate of $5 \mathrm{~kg} / \mathrm{s}$ due to a change from the "low mass velocity" holdup correlation to the "high mass velocity" holdup correlation. 


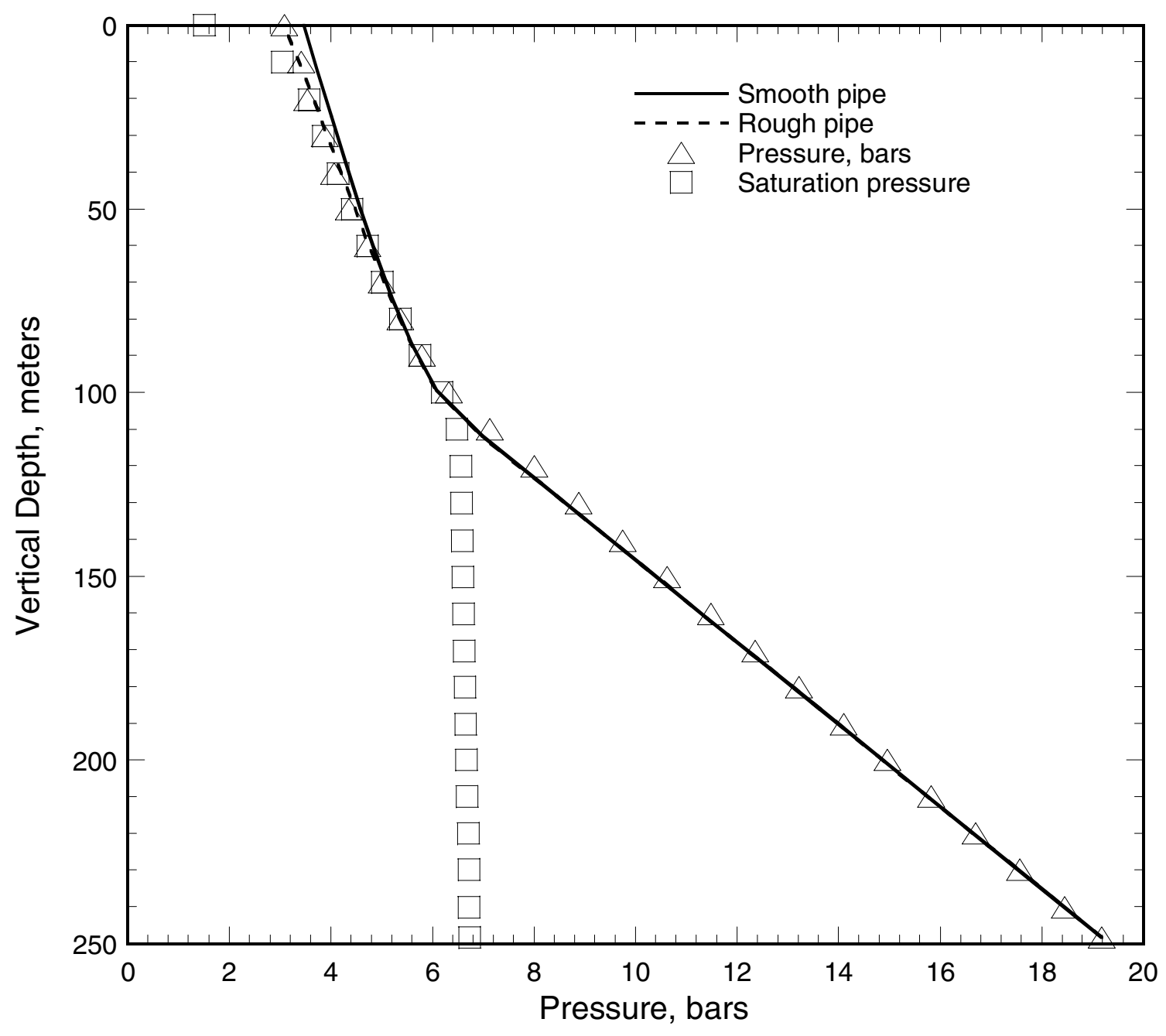

Figure 3.7. Pressure profile (triangle) recorded in the discharging slimhole. The square indicates saturation pressure corresponding to the local measured temperature. The solid (dashed line) line is the computed pressure profile assuming a smooth (rough) pipe. 


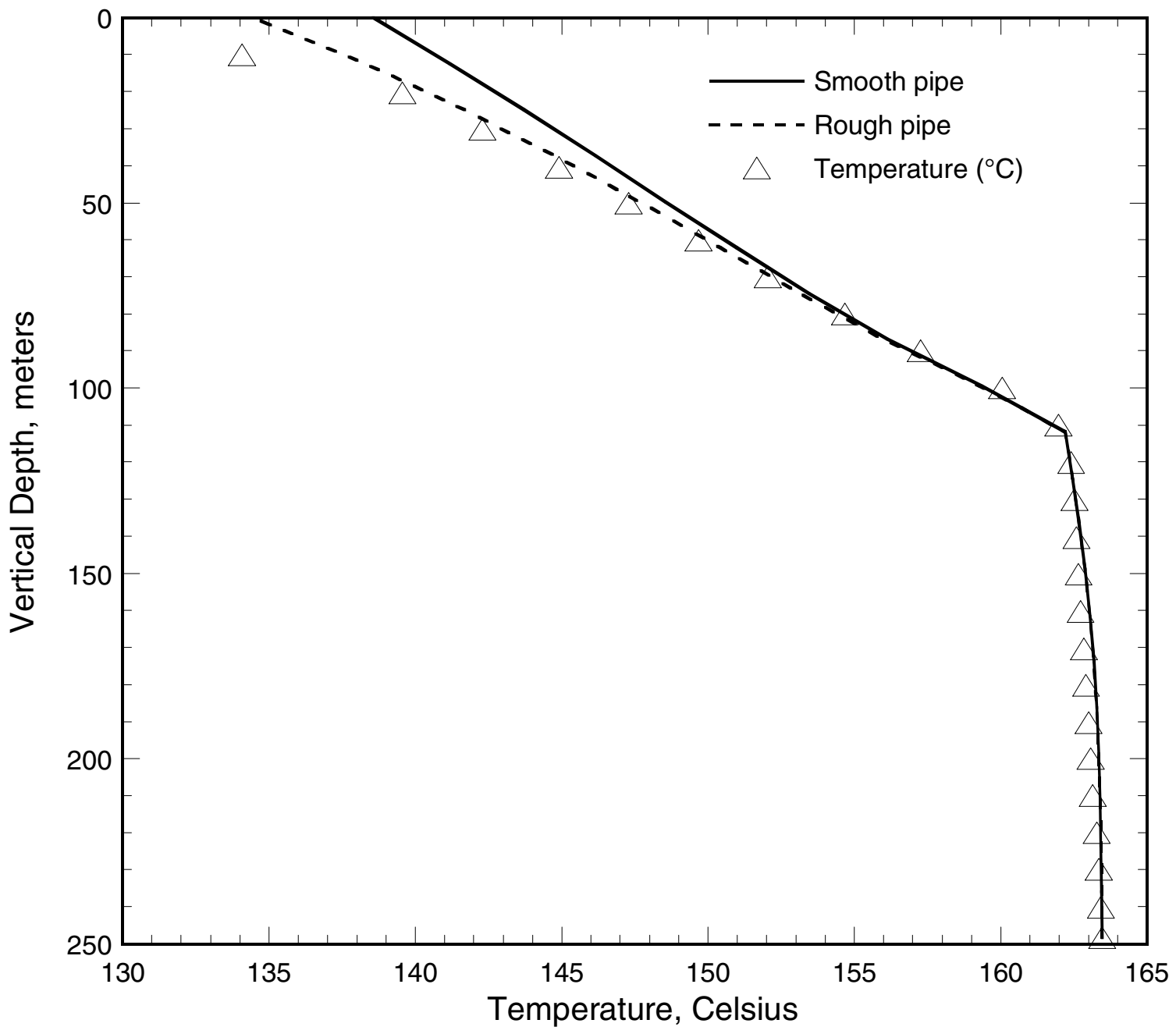

Figure 3.8. Temperature profile (triangle) recorded in the discharging slimhole. The solid (dashed line) line is the computed temperature profile assuming a smooth (rough) pipe. 


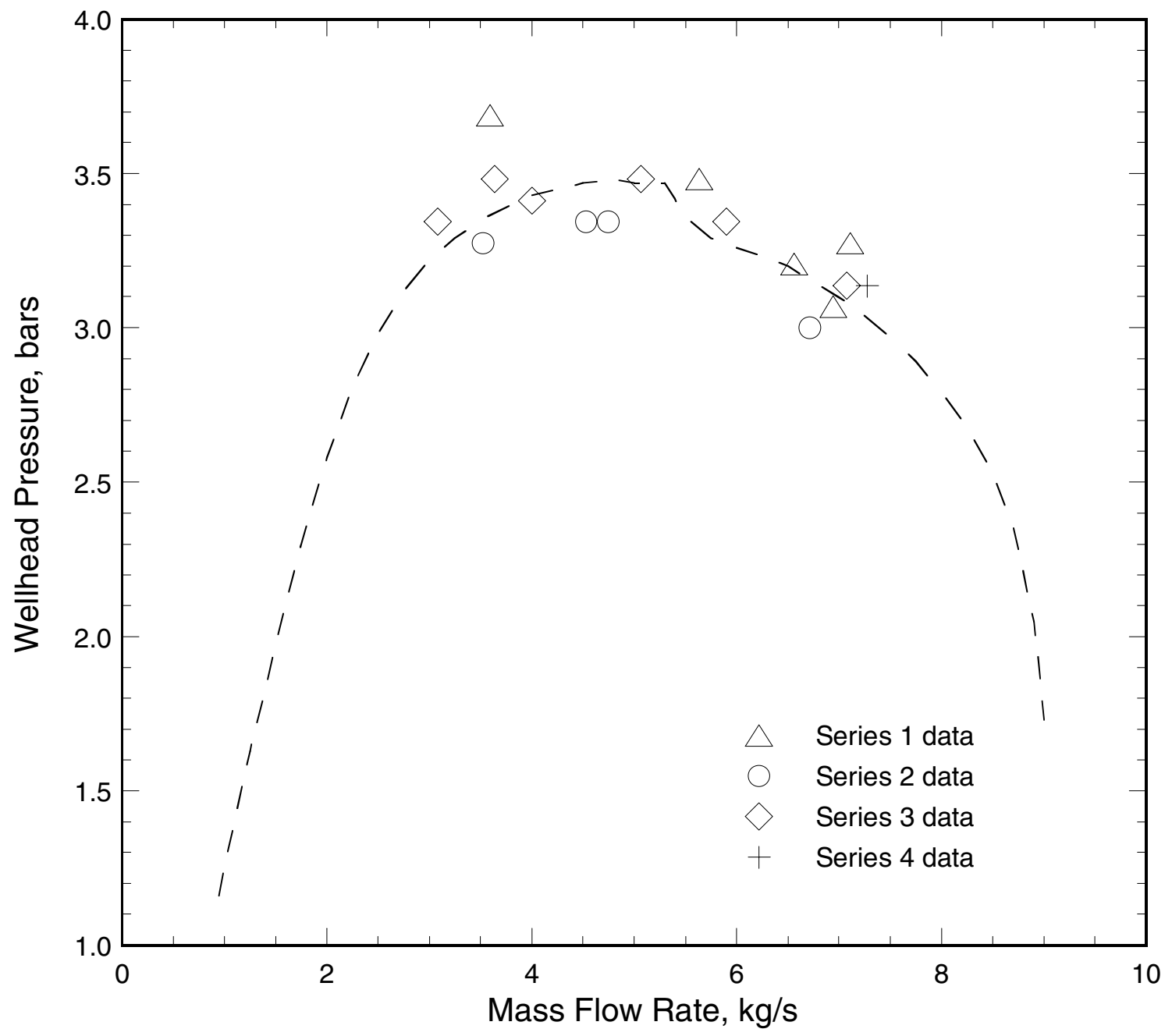

Figure 3.9. Wellhead pressure versus mass flow rate for slimhole SNLG87-29. Measurements (symbols) and computed values (dashed line). 


\section{FUTURE WORK}

The principal goal of the present work is to use high quality data from flowing geothermal wells (Garg and Pritchett, 2001) to devise new liquid holdup correlations for geothermal applications. To make the problem tractable, it was decided to at first develop a holdup correlation restricted to the cased section of geothermal wells. Accordingly, a methodology was formulated for constructing a holdup correlation utilizing measurements in flowing wells. The holdup correlation developed during the current work period (Section 3) displays considerable promise for simulating two-phase flow in the cased section of geothermal wells.

Future plans call for the formulation of a holdup correlation for the open hole/slotted liner section of geothermal wells. The fluid flow in the open hole/slotted liner section is much more complicated than in the cased section. With a single exception (Hadgu, 1989), all of the published papers treat two-phase flow in a pipe (i.e., cased section). Based on the work presented in this report, we believe that it should be possible to use the available well data to formulate a holdup correlation for the open hole/slotted liner section of geothermal wells. 


\section{REFERENCES}

Ansari, A. M., Sylvester, N. D., Sarica, C., Shoham, O., and Brill, J. P. (1994), A Comprehensive Mechanistic Model for Upward Two-Phase Flow in Wellbores, SPE Production \& Facilities, pp. 143-165, May.

Aziz, K., Govier, G., and Fogarasi, M. (1972), Pressure Drop in Wells Producing Oil and Gas, Journal Canadian Petroleum Technology, No. 4, pp. 38-48.

Bankoff, S. G. (1960), A variable density single-fluid model for two-phase flow with particular reference to steam-water flow, Journal of Heat Transfer, ASME Transactions, Series C, Vol. 82, pp. 265-272.

Beggs, H. D. and Brill, J. P. (1973), A Study of Two-Phase Flow in Inclined Pipes, Journal of Petroleum Technology, pp. 607-617, May.

Dukler, A. E., Wickes III, M., and Cleveland, R. G. (1964), Frictional Pressure Drop in TwoPhase Flow: B. An Approach Through Similarity Analysis, A.I.Ch.E. Journal, Vol. 10(1), pp. 44-51.

Duns, H., and Ros, N. C. J. (1963), Vertical Flow of Gas and Liquid Mixtures in Wells, Proceedings $6^{\text {th }}$ World Petroleum Congress, Section II, Paper 22 - PD 6, pp. 451465, Frankfurt Am Main, Germany.

Finger, J., Jacobsen, R., Hickox, C., Combs, J., Polk, G., and Goranson, C. (1999), Slimhole Handbook: Procedures and Recommendations for Slimhole Drilling and Testing in Geothermal Exploration, Report No. SAND99-1976, Sandia National Laboratories, Albuquerque, New Mexico, October.

Gang, X. Z., Golan, M., and Sveen, J. (1990), Determining Downhole Flow Rates of Oil and Gas in Oil Wells Using Pressure Drop and Spinner Response Measurements, Paper No. 20893, Society of Petroleum Engineers, Dallas, Texas.

Garg, S. K. and Combs, J. (2002), A Study of Production/Injection Data from Slim Holes and Large-Diameter Wells at the Okuaizu Geothermal Field, Tohoku, Japan, Report No. SAIC-02/2000, Science Applications International Corporation, San Diego, California, June.

Garg, S. K. and Pritchett, J. W. (2001), Development of New Geothermal Wellbore Holdup Correlations Using Flowing Well Data, Report No. SAIC-01/1061, Science Applications International Corporation, San Diego, California, October. 
Garg, S. K., Pritchett, J. W., and Alexander, J. H. (2003), Development of a New Holdup Correlation for Geothermal Wells: A Preliminary Report, Transactions Geothermal Resources Council, Vol. 27, pp. 801-806.

Hadgu, T. (1989), Vertical Two-Phase Flow Studies and Modeling of Flow in Geothermal Wells, Ph.D. Thesis, University of Auckland, Auckland, New Zealand, July.

Hagedorn, A. R. and Brown, K. E. (1965), Experimental Study of Pressure Gradients Occurring During Continuous Two-Phase Flow in Small-Diameter Vertical Conduits, Journal of Petroleum Technology, pp. 475-484, April.

Hughmark, G. A. (1962), Holdup in gas-liquid flow, Chemical Engineering Progress, Vol. 53(4), pp. 62-65.

Hughmark, G. A., and Pressburg, B. S. (1961), Holdup and Pressure Drop with Gas-Liquid Flow in a Vertical Pipe, A.I.Ch.E. Journal, Vol. 7(4), pp. 677-682.

Orkiszewski, J. (1967), Predicting Two-Phase Pressure Drops in Vertical Pipe, Journal of Petroleum Technology, pp. 829-838, June.

Press, W. H., Flannery, B. P., Teukolsky, S. A., and Vetterling, W. T. (1986), Numerical Recipes, Cambridge University Press.

Pritchett, J. W. (1985), WELBOR: A Computer Program for Calculating Flow in a Producing Geothermal Well, Report No. SSS-R-85-7283, S-Cubed, La Jolla, California (now Science Applications International Corporation, San Diego, California).

Pritchett, J. W. (1993), Preliminary Study of Discharge Characteristics of Slim Holes Compared to Production Wells in Liquid-Dominated Geothermal Reservoirs, Proceedings $18^{\text {th }}$ Workshop Geothermal Reservoir Engineering, Stanford University, Stanford, California, pp. 181-187. 


\section{APPENDIX A: DUKLER I CORRELATION FOR FRICTIONAL PRESSURE DROP}

Frictional Pressure Gradient, F:

$$
F=\frac{2 f_{0} M^{2}}{d_{w} A^{2} \rho_{m}}
$$

where

$$
\begin{aligned}
M & =\text { total mass flow rate } \\
d_{w} & =\text { Inside pipe diameter } \\
A & =\text { Pipe cross-section area }=0.25 \pi d_{w}^{2} \\
\rho_{m} & =\text { Mixture density }=\rho_{l} Y_{l}+\rho_{g}\left(1-Y_{l}\right) \\
Y_{l} & =\text { Flowing liquid volume fraction }=S_{l} v_{l} /\left(S_{l} v_{l}+S_{g} v_{g}\right) \\
\rho_{l}\left(\rho_{g}\right) & =\text { Liquid (gas) density } \\
S_{l}\left(S_{g}\right) & =\text { In - situ liquid (gas) liquid volume fraction }
\end{aligned}
$$

Friction Factor, $f_{0}$ :

$$
f_{0}=0.0014+\frac{0.125}{R n^{0.32}}
$$

where

$$
\begin{aligned}
R n & =\text { Reynolds number }=d_{w} M / A \mu_{m} \\
\mu_{m} & =\text { Mixture viscosity }=\mu_{l} Y_{l}+\mu_{g}\left(1-Y_{l}\right) \\
\mu_{l}\left(\mu_{g}\right) & =\text { Liquid (gas) viscosity }
\end{aligned}
$$

The above definitions for mixture density $\rho_{m}$ and mixture viscosity $\mu_{m}$ are different from those employed by Hughmark (1962) (see Section 3).

The friction factor (A.2) is valid for smooth pipes, and was used by Dukler et al. (1964) to develop their correlation for the frictional pressure gradient. For rough pipes, a modification (based on Moody's friction factor) of equation (A.2) is employed in WELBOR (Pritchett, 1985). The Fortran subroutine (FAKFRK) for computing the friction factor is reproduced below. 


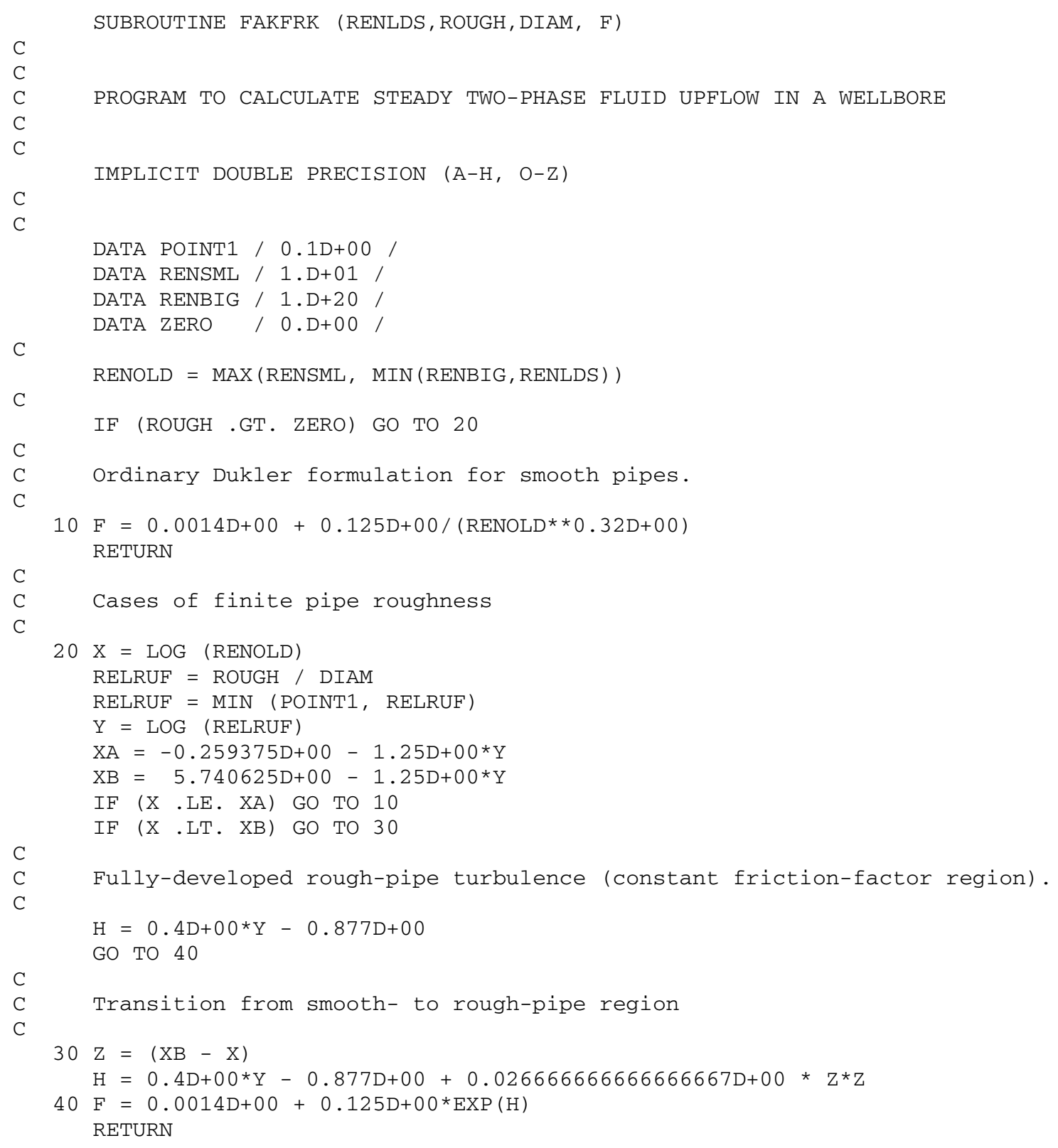




\section{APPENDIX B: PARAMETERS USEDTO MATCH DOWNHOLE PRESSURE AND TEMPERATURE PROFILES}

\section{B.1 WELL A-1}

Well Geometry:

\begin{tabular}{|c|c|c|c|}
\hline $\begin{array}{c}\text { Vertical } \\
\text { Depth } \\
\text { (meters) }\end{array}$ & $\begin{array}{c}\text { Measured } \\
\text { Depth } \\
\text { (meters) }\end{array}$ & $\begin{array}{c}\text { Angle with } \\
\text { Vertical } \\
\text { (Degrees) }\end{array}$ & $\begin{array}{c}\text { Internal } \\
\text { Diameter } \\
\text { (mm) }\end{array}$ \\
\hline 253.0 & 253.0 & 0.000 & 384 \\
793.1 & 809.8 & 14.068 & 315 \\
\hline
\end{tabular}

Stable Temperature Profile:

\begin{tabular}{|c|c|}
\hline $\begin{array}{c}\text { Vertical Depth } \\
\text { (meters) }\end{array}$ & $\begin{array}{c}\text { Temperature } \\
\text { (Degrees Celsius) }\end{array}$ \\
\hline 0 & 26.67 \\
305 & 87.3 \\
606 & 201.7 \\
\hline 793.1 & 228.7 \\
\hline
\end{tabular}

Other Model Input Parameters:

Discharge rate

Pressure at $793.1 \mathrm{mTVD}$

Flowing enthalpy at $793.1 \mathrm{mTVD}$

Fluid (liquid + steam) gas content at 793.1 mTVD

Fluid (liquid + steam) salinity at $793.1 \mathrm{mTVD}$

Hughmark parameter, $\eta$

Roughness factor, $\varepsilon$

Effective thermal conductivity, $\kappa$
$=107 \mathrm{~kg} / \mathrm{s}$

$=18.34 \mathrm{bars}$

$=1105 \mathrm{~kJ} / \mathrm{kg}$

$=0.0018 \mathrm{~kg} / \mathrm{kg}$

$=0.0115 \mathrm{~kg} / \mathrm{kg}$

$=0.11$ for depths $<400 \mathrm{~m}$

$=0.11+0.0022($ depth -400$)$ for $400 \mathrm{~m}<$ depth $<450 \mathrm{~m}$

$=0.33$ for depths $>450 \mathrm{~m}$

$=0.00 \mathrm{~mm}$ for all depths

$=4.0 \mathrm{~W} / \mathrm{m}-{ }^{\circ} \mathrm{C}$ 


\section{B.2 WELL A-2}

Well Geometry:

\begin{tabular}{|c|c|c|c|}
\hline $\begin{array}{c}\text { Vertical } \\
\text { Depth } \\
\text { (meters) }\end{array}$ & $\begin{array}{c}\text { Measured } \\
\text { Depth } \\
\text { (meters) }\end{array}$ & $\begin{array}{c}\text { Angle with } \\
\text { Vertical } \\
\text { (Degrees) }\end{array}$ & $\begin{array}{c}\text { Internal } \\
\text { Diameter } \\
\text { (mm) }\end{array}$ \\
\hline 261.5 & 261.5 & 0.000 & 384 \\
812.3 & 828.8 & 13.853 & 315 \\
\hline
\end{tabular}

Stable Temperature Profile:

\begin{tabular}{|c|c|}
\hline $\begin{array}{c}\text { Vertical Depth } \\
\text { (meters) }\end{array}$ & $\begin{array}{c}\text { Temperature } \\
\text { (Degrees Celsius) }\end{array}$ \\
\hline 0 & 27 \\
890 & 220 \\
\hline
\end{tabular}

\section{Other Model Input Parameters:}

Discharge rate

Pressure at $812.3 \mathrm{mTVD}$

Flowing enthalpy at $812.3 \mathrm{mTVD}$

Fluid (liquid + steam) gas content at 812.3 mTVD

Fluid (liquid + steam) salinity at 812.3 mTVD

Hughmark parameter, $\eta$

Roughness factor, $\varepsilon$

Effective thermal conductivity, $\kappa$
$=107 \mathrm{~kg} / \mathrm{s}$

$=18.83 \mathrm{bars}$

$=1070 \mathrm{~kJ} / \mathrm{kg}$

$=0.00107 \mathrm{~kg} / \mathrm{kg}$

$=0.0134 \mathrm{~kg} / \mathrm{kg}$

$=0.12$ for depths $<350 \mathrm{~m}$

$=0.12+0.0046($ depth -350$)$ for $350 \mathrm{~m}<$ depth $<400 \mathrm{~m}$

$=0.35$ for depths $>400 \mathrm{~m}$

$=0.00 \mathrm{~mm}$ for all depths

$=4.0 \mathrm{~W} / \mathrm{m}-{ }^{\circ} \mathrm{C}$ 


\section{B.3 WELL A-4}

Well Geometry:

\begin{tabular}{|c|c|c|c|}
\hline $\begin{array}{c}\text { Vertical } \\
\text { Depth } \\
\text { (meters) }\end{array}$ & $\begin{array}{c}\text { Measured } \\
\text { Depth } \\
\text { (meters) }\end{array}$ & $\begin{array}{c}\text { Angle with } \\
\text { Vertical } \\
\text { (Degrees) }\end{array}$ & $\begin{array}{c}\text { Internal } \\
\text { Diameter } \\
(\mathrm{mm})\end{array}$ \\
\hline 277.4 & 277.4 & 0.000 & 384 \\
888.5 & 901.6 & 11.759 & 315 \\
\hline
\end{tabular}

Stable Temperature Profile:

\begin{tabular}{|c|c|}
\hline $\begin{array}{c}\text { Vertical Depth } \\
\text { (meters) }\end{array}$ & $\begin{array}{c}\text { Temperature } \\
\text { (Degrees Celsius) }\end{array}$ \\
\hline 0 & 27 \\
305 & 68 \\
754 & 212 \\
888.5 & 227 \\
\hline
\end{tabular}

\section{Other Model Input Parameters:}

Discharge rate

Pressure at $888.5 \mathrm{mTVD}$

Flowing enthalpy at $888.5 \mathrm{mTVD}$

Fluid (liquid + steam) gas content at $888.5 \mathrm{mTVD}$

Fluid (liquid + steam) salinity at $888.5 \mathrm{mTVD}$

Hughmark parameter, $\eta$

Roughness factor, $\varepsilon$

Effective thermal conductivity, $\kappa$
$=135 \mathrm{~kg} / \mathrm{s}$

$=23.49 \mathrm{bars}$

$=1102 \mathrm{~kJ} / \mathrm{kg}$

$=0.0011 \mathrm{~kg} / \mathrm{kg}$

$=0.012 \mathrm{~kg} / \mathrm{kg}$

$=0.09$ for depths $<350 \mathrm{~m}$

$=0.09+0.0062($ depth -350$)$ for $350 \mathrm{~m}<$ depth $<400 \mathrm{~m}$

$=0.40$ for depths $>400 \mathrm{~m}$

$=0.00 \mathrm{~mm}$ for all depths

$=4.0 \mathrm{~W} / \mathrm{m}^{-}{ }^{\circ} \mathrm{C}$ 


\section{B.4 WELL A-6}

Well Geometry:

\begin{tabular}{|c|c|c|c|}
\hline $\begin{array}{c}\text { Vertical } \\
\text { Depth } \\
\text { (meters) }\end{array}$ & $\begin{array}{c}\text { Measured } \\
\text { Depth } \\
\text { (meters) }\end{array}$ & $\begin{array}{c}\text { Angle with } \\
\text { Vertical } \\
\text { (Degrees) }\end{array}$ & $\begin{array}{c}\text { Internal } \\
\text { Diameter } \\
(\mathrm{mm})\end{array}$ \\
\hline 450.5 & 450.5 & 0.000 & 384 \\
962.9 & 975.4 & 12.529 & 315 \\
\hline 1216.2 & 1246.3 & 20.767 & 315 \\
\hline
\end{tabular}

Stable Temperature Profile:

\begin{tabular}{|c|c|}
\hline $\begin{array}{c}\text { Vertical Depth } \\
\text { (meters) }\end{array}$ & $\begin{array}{c}\text { Temperature } \\
\text { (Degrees Celsius) }\end{array}$ \\
\hline 0 & 27 \\
610 & 121 \\
906 & 238 \\
1216 & 267 \\
\hline
\end{tabular}

\section{Other Model Input Parameters:}

Discharge rate

Pressure at $1216.2 \mathrm{mTVD}$

Flowing enthalpy at $1216.2 \mathrm{mTVD}$

Fluid (liquid + steam) gas content at $1216.2 \mathrm{mTVD}=0.00034 \mathrm{~kg} / \mathrm{kg}$

Fluid (liquid + steam) salinity at 1216.2 mTVD

Hughmark parameter, $\eta$

Roughness factor, $\varepsilon$

Effective thermal conductivity, $\kappa$
$=145 \mathrm{~kg} / \mathrm{s}$

$=44.47 \mathrm{bars}$

$=1133 \mathrm{~kJ} / \mathrm{kg}$

$=0.0162 \mathrm{~kg} / \mathrm{kg}$

$=0.20$ for depths $<450 \mathrm{~m}$

$=0.20+0.016($ depth -450$)$ for $450 \mathrm{~m}<$ depth $<500 \mathrm{~m}$

$=1.00$ for depths $>500 \mathrm{~m}$

$=0.00 \mathrm{~mm}$ for depth $<450.5 \mathrm{~m}$

$=0.10 \mathrm{~mm}$ for depth $>450.5 \mathrm{~m}$

$=4.0 \mathrm{~W} / \mathrm{m}^{-}{ }^{\circ} \mathrm{C}$ 


\section{B.5 WELL A-7}

Well Geometry:

\begin{tabular}{|c|c|c|c|}
\hline $\begin{array}{c}\text { Vertical } \\
\text { Depth } \\
\text { (meters) }\end{array}$ & $\begin{array}{c}\text { Measured } \\
\text { Depth } \\
\text { (meters) }\end{array}$ & $\begin{array}{c}\text { Angle with } \\
\text { Vertical } \\
\text { (Degrees) }\end{array}$ & $\begin{array}{c}\text { Internal } \\
\text { Diameter } \\
(\mathrm{mm})\end{array}$ \\
\hline 494.1 & 494.1 & 0.000 & 384 \\
762.0 & 769.6 & 13.489 & 315 \\
\hline 1466.4 & 1517.3 & 19.595 & 315 \\
\hline
\end{tabular}

Stable Temperature Profile:

\begin{tabular}{|c|c|}
\hline $\begin{array}{c}\text { Vertical Depth } \\
\text { (meters) }\end{array}$ & $\begin{array}{c}\text { Temperature } \\
\text { (Degrees Celsius) }\end{array}$ \\
\hline 0 & 27 \\
457 & 97 \\
610 & 228 \\
1466 & 274 \\
\hline
\end{tabular}

\section{Other Model Input Parameters:}

Discharge rate

Pressure at $1466.4 \mathrm{mTVD}$

Flowing enthalpy at $1466.4 \mathrm{mTVD}$

Fluid (liquid + steam) gas content at $1466.4 \mathrm{mTVD}=0.00072 \mathrm{~kg} / \mathrm{kg}$

Fluid (liquid + steam) salinity at 1466.4 mTVD

Hughmark parameter, $\eta$

Roughness factor, $\varepsilon$

Effective thermal conductivity, $\kappa$
$=202 \mathrm{~kg} / \mathrm{s}$

$=59.08 \mathrm{bars}$

$=1100 \mathrm{~kJ} / \mathrm{kg}$

$=0.0137 \mathrm{~kg} / \mathrm{kg}$

$=0.20$ for all depths

$=0.00 \mathrm{~mm}$ for all depths

$=4.0 \mathrm{~W} / \mathrm{m}^{-}{ }^{\circ} \mathrm{C}$ 


\section{B.6 WELL A-8}

Well Geometry:

\begin{tabular}{|c|c|c|c|}
\hline $\begin{array}{c}\text { Vertical } \\
\text { Depth } \\
\text { (meters) }\end{array}$ & $\begin{array}{c}\text { Measured } \\
\text { Depth } \\
\text { (meters) }\end{array}$ & $\begin{array}{c}\text { Angle with } \\
\text { Vertical } \\
\text { (Degrees) }\end{array}$ & $\begin{array}{c}\text { Internal } \\
\text { Diameter } \\
\text { (mm) }\end{array}$ \\
\hline 563.9 & 563.9 & 0.000 & 384 \\
1016.8 & 1024.7 & 10.625 & 315 \\
\hline
\end{tabular}

Stable Temperature Profile:

\begin{tabular}{|c|c|}
\hline $\begin{array}{c}\text { Vertical Depth } \\
\text { (meters) }\end{array}$ & $\begin{array}{c}\text { Temperature } \\
\text { (Degrees Celsius) }\end{array}$ \\
\hline 0 & 27 \\
305 & 74 \\
610 & 223 \\
1020 & 242 \\
\hline
\end{tabular}

\section{Other Model Input Parameters:}

Discharge rate

Pressure at 1016.8 mTVD

Flowing enthalpy at $1016.8 \mathrm{mTVD}$

Fluid (liquid + steam) gas content at $1016.8 \mathrm{mTVD}=0.0011 \mathrm{~kg} / \mathrm{kg}$

Fluid (liquid + steam) salinity at $1016.8 \mathrm{mTVD} \quad=0.0135 \mathrm{~kg} / \mathrm{kg}$

Hughmark parameter, $\eta$

Roughness factor, $\varepsilon$

Effective thermal conductivity, $\kappa$
$=101 \mathrm{~kg} / \mathrm{s}$

$=22.17 \mathrm{bars}$

$=1072 \mathrm{~kJ} / \mathrm{kg}$

$=0.10$ for depths $<550 \mathrm{~m}$

$=0.10+0.009($ depth -550$)$ for $550 \mathrm{~m}<$ depth $<600 \mathrm{~m}$

$=0.55$ for depths $>600 \mathrm{~m}$

$=0.00 \mathrm{~mm}$ for all depths

$=4.0 \mathrm{~W} / \mathrm{m}-{ }^{\circ} \mathrm{C}$ 


\section{B.7 WELL A-9}

Well Geometry:

\begin{tabular}{|c|c|c|c|}
\hline $\begin{array}{c}\text { Vertical } \\
\text { Depth } \\
\text { (meters) }\end{array}$ & $\begin{array}{c}\text { Measured } \\
\text { Depth } \\
\text { (meters) }\end{array}$ & $\begin{array}{c}\text { Angle with } \\
\text { Vertical } \\
\text { (Degrees) }\end{array}$ & $\begin{array}{c}\text { Internal } \\
\text { Diameter } \\
(\mathrm{mm})\end{array}$ \\
\hline 559.0 & 559.0 & 0.000 & 384 \\
\hline 1033.3 & 1048.2 & 14.177 & 315 \\
\hline
\end{tabular}

Stable Temperature Profile:

\begin{tabular}{|c|c|}
\hline $\begin{array}{c}\text { Vertical Depth } \\
\text { (meters) }\end{array}$ & $\begin{array}{c}\text { Temperature } \\
\text { (Degrees Celsius) }\end{array}$ \\
\hline 0 & 27 \\
610 & 121 \\
909 & 239 \\
1034 & 251 \\
\hline
\end{tabular}

\section{Other Model Input Parameters:}

Discharge rate

Pressure at $1033.3 \mathrm{mTVD}$

Flowing enthalpy at $1033.3 \mathrm{mTVD}$

Fluid (liquid + steam) gas content at $1033.3 \mathrm{mTVD}=0.00086 \mathrm{~kg} / \mathrm{kg}$

Fluid (liquid + steam) salinity at 1033.3 mTVD

Hughmark parameter, $\eta$

Roughness factor, $\varepsilon$

Effective thermal conductivity, $\kappa$
$=139 \mathrm{~kg} / \mathrm{s}$

$=31.10 \mathrm{bars}$

$=1131 \mathrm{~kJ} / \mathrm{kg}$

$=0.0134 \mathrm{~kg} / \mathrm{kg}$

$=0.22$ for depths $<550 \mathrm{~m}$

$=0.22+0.0056($ depth -550$)$ for $550 \mathrm{~m}<$ depth $<600 \mathrm{~m}$

$=0.50$ for depths $>600 \mathrm{~m}$

$=0.00 \mathrm{~mm}$ for all depths

$=4.0 \mathrm{~W} / \mathrm{m}^{-}{ }^{\circ} \mathrm{C}$ 


\section{B.8 WELL A-10}

Well Geometry:

\begin{tabular}{|c|c|c|c|}
\hline $\begin{array}{c}\text { Vertical } \\
\text { Depth } \\
\text { (meters) }\end{array}$ & $\begin{array}{c}\text { Measured } \\
\text { Depth } \\
\text { (meters) }\end{array}$ & $\begin{array}{c}\text { Angle with } \\
\text { Vertical } \\
\text { (Degrees) }\end{array}$ & $\begin{array}{c}\text { Internal } \\
\text { Diameter } \\
(\mathrm{mm})\end{array}$ \\
\hline 435.0 & 435.0 & 0.000 & 384 \\
\hline 662.0 & 663.8 & 7.192 & 315 \\
\hline 806.2 & 816.3 & 18.990 & 315 \\
1240.0 & 1291.1 & 23.986 & 315 \\
\hline
\end{tabular}

Stable Temperature Profile:

\begin{tabular}{|c|c|}
\hline $\begin{array}{c}\text { Vertical Depth } \\
\text { (meters) }\end{array}$ & $\begin{array}{c}\text { Temperature } \\
\text { (Degrees Celsius) }\end{array}$ \\
\hline 0 & 27 \\
610 & 121 \\
897 & 226 \\
1240 & 245 \\
\hline
\end{tabular}

\section{Other Model Input Parameters:}

Discharge rate

Pressure at $1240.0 \mathrm{mTVD}$

Flowing enthalpy at $1240.0 \mathrm{mTVD}$

Fluid (liquid + steam) gas content at $1240.0 \mathrm{mTVD}$

Fluid (liquid + steam) salinity at 1240.0 mTVD

Hughmark parameter, $\eta$

Roughness factor, $\varepsilon$

Effective thermal conductivity, $\kappa$
$=145 \mathrm{~kg} / \mathrm{s}$

$=35.46 \mathrm{bars}$

$=1075 \mathrm{~kJ} / \mathrm{kg}$

$=0.0007 \mathrm{~kg} / \mathrm{kg}$

$=0.0129 \mathrm{~kg} / \mathrm{kg}$

$=0.09$ for depths $<400 \mathrm{~m}$

$=0.09+0.0066($ depth -400$)$ for $400 \mathrm{~m}<$ depth $<450 \mathrm{~m}$

$=0.42$ for depths $>450 \mathrm{~m}$

$=0.00 \mathrm{~mm}$ for all depths

$=4.0 \mathrm{~W} / \mathrm{m}^{-}{ }^{\circ} \mathrm{C}$ 


\section{B.9 WELL A-11}

Well Geometry:

\begin{tabular}{|c|c|c|c|}
\hline $\begin{array}{c}\text { Vertical } \\
\text { Depth } \\
\text { (meters) }\end{array}$ & $\begin{array}{c}\text { Measured } \\
\text { Depth } \\
\text { (meters) }\end{array}$ & $\begin{array}{c}\text { Angle with } \\
\text { Vertical } \\
\text { (Degrees) }\end{array}$ & $\begin{array}{c}\text { Internal } \\
\text { Diameter } \\
(\mathrm{mm})\end{array}$ \\
\hline 444.1 & 444.1 & 0.000 & 384 \\
\hline 1010.1 & 1052.2 & 21.445 & 315 \\
\hline
\end{tabular}

Stable Temperature Profile:

\begin{tabular}{|c|c|}
\hline $\begin{array}{c}\text { Vertical Depth } \\
\text { (meters) }\end{array}$ & $\begin{array}{c}\text { Temperature } \\
\text { (Degrees Celsius) }\end{array}$ \\
\hline 0 & 27 \\
755 & 144 \\
1010 & 250 \\
\hline
\end{tabular}

\section{Other Model Input Parameters:}

Discharge rate

Pressure at 1010.1 mTVD

Flowing enthalpy at $1010.1 \mathrm{mTVD}$

Fluid (liquid + steam) gas content at $1010.1 \mathrm{mTVD}=0.00053 \mathrm{~kg} / \mathrm{kg}$

Fluid (liquid + steam) salinity at 1010.1 mTVD

Hughmark parameter, $\eta$

Roughness factor, $\varepsilon$

Effective thermal conductivity, $\kappa$
$=126 \mathrm{~kg} / \mathrm{s}$

$=27.20 \mathrm{bars}$

$=1098 \mathrm{~kJ} / \mathrm{kg}$

$=0.0136 \mathrm{~kg} / \mathrm{kg}$

$=0.20$ for depths $<450 \mathrm{~m}$

$=0.20+0.010($ depth -450$)$ for $450 \mathrm{~m}<$ depth $<500 \mathrm{~m}$

$=0.70$ for depths $>500 \mathrm{~m}$

$=0.00 \mathrm{~mm}$ for all depths

$=4.0 \mathrm{~W} / \mathrm{m}^{-}{ }^{\circ} \mathrm{C}$ 


\section{B.10 WELL A-12}

Well Geometry:

\begin{tabular}{|c|c|c|c|}
\hline $\begin{array}{c}\text { Vertical } \\
\text { Depth } \\
\text { (meters) }\end{array}$ & $\begin{array}{c}\text { Measured } \\
\text { Depth } \\
\text { (meters) }\end{array}$ & $\begin{array}{c}\text { Angle with } \\
\text { Vertical } \\
\text { (Degrees) }\end{array}$ & $\begin{array}{c}\text { Internal } \\
\text { Diameter } \\
(\mathrm{mm})\end{array}$ \\
\hline 377.6 & 337.6 & 0.000 & 384 \\
\hline 876.0 & 889.4 & 13.140 & 315 \\
\hline
\end{tabular}

Stable Temperature Profile:

\begin{tabular}{|c|c|}
\hline $\begin{array}{c}\text { Vertical Depth } \\
\text { (meters) }\end{array}$ & $\begin{array}{c}\text { Temperature } \\
\text { (Degrees Celsius) }\end{array}$ \\
\hline 0 & 27 \\
609 & 121 \\
900 & 245 \\
\hline
\end{tabular}

\section{Other Model Input Parameters:}

Discharge rate

Pressure at $876.0 \mathrm{mTVD}$

Flowing enthalpy at $876.0 \mathrm{mTVD}$

Fluid (liquid + steam) gas content at 876.0 mTVD

Fluid (liquid + steam) salinity at $876.0 \mathrm{mTVD}$

Hughmark parameter, $\eta$

Roughness factor, $\varepsilon$

Effective thermal conductivity, $\kappa$
$=113 \mathrm{~kg} / \mathrm{s}$

$=21.65 \mathrm{bars}$

$=1190 \mathrm{~kJ} / \mathrm{kg}$

$=0.0052 \mathrm{~kg} / \mathrm{kg}$

$=0.012 \mathrm{~kg} / \mathrm{kg}$

$=0.10$ for depths $<450 \mathrm{~m}$

$=0.10+0.001($ depth -450$)$ for $450 \mathrm{~m}<$ depth $<500 \mathrm{~m}$

$=0.15$ for depths $>500 \mathrm{~m}$

$=0.00 \mathrm{~mm}$ for all depths

$=4.0 \mathrm{~W} / \mathrm{m}^{\circ}{ }^{\circ} \mathrm{C}$ 


\section{B.11 WELL A-13}

\section{Well Geometry:}

\begin{tabular}{|c|c|c|c|}
\hline $\begin{array}{c}\text { Vertical } \\
\text { Depth } \\
\text { (meters) }\end{array}$ & $\begin{array}{c}\text { Measured } \\
\text { Depth } \\
\text { (meters) }\end{array}$ & $\begin{array}{c}\text { Angle with } \\
\text { Vertical } \\
\text { (Degrees) }\end{array}$ & $\begin{array}{c}\text { Internal } \\
\text { Diameter } \\
(\mathrm{mm})\end{array}$ \\
\hline 392.3 & 392.3 & 0.000 & 384 \\
\hline 983.9 & 1012.5 & 17.468 & 315 \\
\hline
\end{tabular}

Stable Temperature Profile:

\begin{tabular}{|c|c|}
\hline $\begin{array}{c}\text { Vertical Depth } \\
\text { (meters) }\end{array}$ & $\begin{array}{c}\text { Temperature } \\
\text { (Degrees Celsius) }\end{array}$ \\
\hline 0 & 27 \\
606 & 121 \\
893 & 250 \\
\hline
\end{tabular}

\section{Other Model Input Parameters:}

Discharge rate

Pressure at 983.9 mTVD

Flowing enthalpy at $983.9 \mathrm{mTVD}$

Fluid (liquid + steam) gas content at 983.9 mTVD

Fluid (liquid + steam) salinity at 983.9 mTVD

Hughmark parameter, $\eta$

Roughness factor, $\varepsilon$

Effective thermal conductivity, $\kappa$
$=88 \mathrm{~kg} / \mathrm{s}$

$=20.03 \mathrm{bars}$

$=1296 \mathrm{~kJ} / \mathrm{kg}$

$=0.0075 \mathrm{~kg} / \mathrm{kg}$

$=0.0112 \mathrm{~kg} / \mathrm{kg}$

$=0.09$ for all depths

$=0.00 \mathrm{~mm}$ for all depths

$=4.0 \mathrm{~W} / \mathrm{m}-{ }^{\circ} \mathrm{C}$ 


\section{B.12 WELL A-14}

Well Geometry:

\begin{tabular}{|c|c|c|c|}
\hline $\begin{array}{c}\text { Vertical } \\
\text { Depth } \\
\text { (meters) }\end{array}$ & $\begin{array}{c}\text { Measured } \\
\text { Depth } \\
\text { (meters) }\end{array}$ & $\begin{array}{c}\text { Angle with } \\
\text { Vertical } \\
\text { (Degrees) }\end{array}$ & $\begin{array}{c}\text { Internal } \\
\text { Diameter } \\
(\mathrm{mm})\end{array}$ \\
\hline 295.0 & 295.0 & 0.000 & 384 \\
\hline 932.4 & 932.7 & 1.758 & 315 \\
\hline
\end{tabular}

Stable Temperature Profile:

\begin{tabular}{|c|c|}
\hline $\begin{array}{c}\text { Vertical Depth } \\
\text { (meters) }\end{array}$ & $\begin{array}{c}\text { Temperature } \\
\text { (Degrees Celsius) }\end{array}$ \\
\hline 0 & 27 \\
609 & 121 \\
\hline 932 & 225 \\
\hline
\end{tabular}

\section{Other Model Input Parameters:}

Discharge rate

Pressure at $932.4 \mathrm{mTVD}$

Flowing enthalpy at $932.4 \mathrm{mTVD}$

Fluid (liquid + steam) gas content at 932.4 mTVD

Fluid (liquid + steam) salinity at 932.4 mTVD

Hughmark parameter, $\eta$

Roughness factor, $\varepsilon$

Effective thermal conductivity, $\kappa$
$=107 \mathrm{~kg} / \mathrm{s}$

$=23.67 \mathrm{bars}$

$=1085 \mathrm{~kJ} / \mathrm{kg}$

$=0.00032 \mathrm{~kg} / \mathrm{kg}$

$=0.0139 \mathrm{~kg} / \mathrm{kg}$

$=0.14$ for depths $<400 \mathrm{~m}$

$=0.14+0.0052($ depth -400$)$ for $400 \mathrm{~m}<$ depth $<450 \mathrm{~m}$

$=0.40$ for depths $>450 \mathrm{~m}$

$=0.00 \mathrm{~mm}$ for all depths

$=4.0 \mathrm{~W} / \mathrm{m}^{\circ}{ }^{\circ} \mathrm{C}$ 


\section{B.13 WELL A-16}

\section{Well Geometry:}

\begin{tabular}{|c|c|c|c|}
\hline $\begin{array}{c}\text { Vertical } \\
\text { Depth } \\
\text { (meters) }\end{array}$ & $\begin{array}{c}\text { Measured } \\
\text { Depth } \\
\text { (meters) }\end{array}$ & $\begin{array}{c}\text { Angle with } \\
\text { Vertical } \\
\text { (Degrees) }\end{array}$ & $\begin{array}{c}\text { Internal } \\
\text { Diameter } \\
(\mathrm{mm})\end{array}$ \\
\hline 375.8 & 375.8 & 0.000 & 384 \\
\hline 877.8 & 923.8 & 23.644 & 315 \\
\hline
\end{tabular}

Stable Temperature Profile:

\begin{tabular}{|c|c|}
\hline $\begin{array}{c}\text { Vertical Depth } \\
\text { (meters) }\end{array}$ & $\begin{array}{c}\text { Temperature } \\
\text { (Degrees Celsius) }\end{array}$ \\
\hline 0 & 27 \\
607 & 121 \\
882 & 200 \\
\hline
\end{tabular}

\section{Other Model Input Parameters:}

Discharge rate

Pressure at $877.8 \mathrm{mTVD}$

Flowing enthalpy at $877.8 \mathrm{mTVD}$

Fluid (liquid + steam) gas content at $877.8 \mathrm{mTVD}$

Fluid (liquid + steam) salinity at $877.8 \mathrm{mTVD}$

Hughmark parameter, $\eta$

Roughness factor, $\varepsilon$

Effective thermal conductivity, $\kappa$
$=79 \mathrm{~kg} / \mathrm{s}$

$=21.70 \mathrm{bars}$

$=1099 \mathrm{~kJ} / \mathrm{kg}$

$=0.00027 \mathrm{~kg} / \mathrm{kg}$

$=0.0126 \mathrm{~kg} / \mathrm{kg}$

$=0.20$ for depths $<400 \mathrm{~m}$

$=0.20+0.009($ depth -400$)$ for $400 \mathrm{~m}<$ depth $<450 \mathrm{~m}$

$=0.65$ for depths $>450 \mathrm{~m}$

$=0.00 \mathrm{~mm}$ for all depths

$=4.0 \mathrm{~W} / \mathrm{m}^{\circ}{ }^{\circ} \mathrm{C}$ 


\section{B.14 WELL A-18}

Well Geometry:

\begin{tabular}{|c|c|c|c|}
\hline $\begin{array}{c}\text { Vertical } \\
\text { Depth } \\
\text { (meters) }\end{array}$ & $\begin{array}{c}\text { Measured } \\
\text { Depth } \\
\text { (meters) }\end{array}$ & $\begin{array}{c}\text { Angle with } \\
\text { Vertical } \\
\text { (Degrees) }\end{array}$ & $\begin{array}{c}\text { Internal } \\
\text { Diameter } \\
(\mathrm{mm})\end{array}$ \\
\hline 281.0 & 281.0 & 0.000 & 384 \\
\hline 768.1 & 768.4 & 2.010 & 315 \\
\hline
\end{tabular}

Stable Temperature Profile:

\begin{tabular}{|c|c|}
\hline $\begin{array}{c}\text { Vertical Depth } \\
\text { (meters) }\end{array}$ & $\begin{array}{c}\text { Temperature } \\
\text { (Degrees Celsius) }\end{array}$ \\
\hline 0 & 27 \\
305 & 71 \\
730 & 215 \\
800 & 220 \\
\hline
\end{tabular}

\section{Other Model Input Parameters:}

Discharge rate

Pressure at $768.1 \mathrm{mTVD}$

Flowing enthalpy at $768.1 \mathrm{mTVD}$

Fluid (liquid + steam) gas content at $768.1 \mathrm{mTVD}$

Fluid (liquid + steam) salinity at $768.1 \mathrm{mTVD}$

Hughmark parameter, $\eta$

Roughness factor, $\varepsilon$

Effective thermal conductivity, $\kappa$

$$
=40 \mathrm{~kg} / \mathrm{s}
$$

$=16.28 \mathrm{bars}$

$=1269 \mathrm{~kJ} / \mathrm{kg}$

$=0.0142 \mathrm{~kg} / \mathrm{kg}$

$=0.0093 \mathrm{~kg} / \mathrm{kg}$

$=0.43$ for depths $<350 \mathrm{~m}$

$=0.43+0.0074($ depth -350$)$ for $350 \mathrm{~m}<$ depth $<400 \mathrm{~m}$

$=0.80$ for depths $>400 \mathrm{~m}$

$=0.00 \mathrm{~mm}$ for all depths

$=4.0 \mathrm{~W} / \mathrm{m}-{ }^{\circ} \mathrm{C}$ 


\section{B.15 WELL A-19}

\section{Well Geometry:}

\begin{tabular}{|c|c|c|c|}
\hline $\begin{array}{c}\text { Vertical } \\
\text { Depth } \\
\text { (meters) }\end{array}$ & $\begin{array}{c}\text { Measured } \\
\text { Depth } \\
\text { (meters) }\end{array}$ & $\begin{array}{c}\text { Angle with } \\
\text { Vertical } \\
\text { (Degrees) }\end{array}$ & $\begin{array}{c}\text { Internal } \\
\text { Diameter } \\
(\mathrm{mm})\end{array}$ \\
\hline 403.6 & 403.6 & 0.000 & 384 \\
\hline 998.5 & 1021.7 & 15.748 & 315 \\
\hline
\end{tabular}

Stable Temperature Profile:

\begin{tabular}{|c|c|}
\hline $\begin{array}{c}\text { Vertical Depth } \\
\text { (meters) }\end{array}$ & $\begin{array}{c}\text { Temperature } \\
\text { (Degrees Celsius) }\end{array}$ \\
\hline 0 & 27 \\
305 & 74 \\
\hline 1040 & 233 \\
\hline
\end{tabular}

\section{Other Model Input Parameters:}

Discharge rate

Pressure at 998.5 mTVD

Flowing enthalpy at $998.5 \mathrm{mTVD}$

Fluid (liquid + steam) gas content at 998.5 mTVD

Fluid (liquid + steam) salinity at 998.5 mTVD

Hughmark parameter, $\eta$

Roughness factor, $\varepsilon$

Effective thermal conductivity, $\kappa$
$=123 \mathrm{~kg} / \mathrm{s}$

$=22.05 \mathrm{bars}$

$=1108 \mathrm{~kJ} / \mathrm{kg}$

$=0.0028 \mathrm{~kg} / \mathrm{kg}$

$=0.0128 \mathrm{~kg} / \mathrm{kg}$

$=0.09$ for depths $<450 \mathrm{~m}$

$=0.09+0.0034($ depth -450$)$ for $450 \mathrm{~m}<$ depth $<500 \mathrm{~m}$

$=0.26$ for depths $>500 \mathrm{~m}$

$=0.00 \mathrm{~mm}$ for all depths

$=4.0 \mathrm{~W} / \mathrm{m}^{\circ}{ }^{\circ} \mathrm{C}$ 


\section{B.16 WELL A-20}

Well Geometry:

\begin{tabular}{|c|c|c|c|}
\hline $\begin{array}{c}\text { Vertical } \\
\text { Depth } \\
\text { (meters) }\end{array}$ & $\begin{array}{c}\text { Measured } \\
\text { Depth } \\
\text { (meters) }\end{array}$ & $\begin{array}{c}\text { Angle with } \\
\text { Vertical } \\
\text { (Degrees) }\end{array}$ & $\begin{array}{c}\text { Internal } \\
\text { Diameter } \\
(\mathrm{mm})\end{array}$ \\
\hline 380.7 & 380.7 & 0.000 & 384 \\
\hline 1023.8 & 1037.8 & 11.848 & 315 \\
\hline
\end{tabular}

Stable Temperature Profile:

\begin{tabular}{|c|c|}
\hline $\begin{array}{c}\text { Vertical Depth } \\
\text { (meters) }\end{array}$ & $\begin{array}{c}\text { Temperature } \\
\text { (Degrees Celsius) }\end{array}$ \\
\hline 0 & 27 \\
305 & 74 \\
607 & 153 \\
1060 & 228 \\
\hline
\end{tabular}

\section{Other Model Input Parameters:}

Discharge rate

Pressure at 1023.8 mTVD

$$
=120 \mathrm{~kg} / \mathrm{s}
$$

$=23.12 \mathrm{bars}$

Flowing enthalpy at $1023.8 \mathrm{mTVD}$

$=1120 \mathrm{~kJ} / \mathrm{kg}$

Fluid (liquid + steam) gas content at $1023.8 \mathrm{mTVD}=0.0035 \mathrm{~kg} / \mathrm{kg}$

Fluid (liquid + steam) salinity at $1023.8 \mathrm{mTVD} \quad=0.0101 \mathrm{~kg} / \mathrm{kg}$

Hughmark parameter, $\eta$

$=0.10$ for depths $<450 \mathrm{~m}$

$=0.10+0.0042($ depth -450$)$ for $450 \mathrm{~m}<$ depth $<500 \mathrm{~m}$

Roughness factor, $\varepsilon$

$=0.31$ for depths $>500 \mathrm{~m}$

Effective thermal conductivity, $\kappa$

$=0.00 \mathrm{~mm}$ for all depths

$=4.0 \mathrm{~W} / \mathrm{m}-{ }^{\circ} \mathrm{C}$ 


\section{B.17 WELL A-21}

Well Geometry:

\begin{tabular}{|c|c|c|c|}
\hline $\begin{array}{c}\text { Vertical } \\
\text { Depth } \\
\text { (meters) }\end{array}$ & $\begin{array}{c}\text { Measured } \\
\text { Depth } \\
\text { (meters) }\end{array}$ & $\begin{array}{c}\text { Angle with } \\
\text { Vertical } \\
\text { (Degrees) }\end{array}$ & $\begin{array}{c}\text { Internal } \\
\text { Diameter } \\
(\mathrm{mm})\end{array}$ \\
\hline 443.7 & 443.8 & 1.216 & 384 \\
\hline 1010.1 & 1052.2 & 21.414 & 315 \\
\hline
\end{tabular}

Stable Temperature Profile:

\begin{tabular}{|c|c|}
\hline $\begin{array}{c}\text { Vertical Depth } \\
\text { (meters) }\end{array}$ & $\begin{array}{c}\text { Temperature } \\
\text { (Degrees Celsius) }\end{array}$ \\
\hline 0 & 20 \\
\hline 1011 & 224 \\
\hline
\end{tabular}

\section{Other Model Input Parameters:}

Discharge rate

Pressure at $1010.1 \mathrm{mTVD}$

Flowing enthalpy at $1010.1 \mathrm{mTVD}$

Fluid (liquid + steam) gas content at 1010.1 mTVD

Fluid (liquid + steam) salinity at $1010.1 \mathrm{mTVD}$

Hughmark parameter, $\eta$

Roughness factor, $\varepsilon$

Effective thermal conductivity, $\kappa$
$=89.5 \mathrm{~kg} / \mathrm{s}$

$=23.90 \mathrm{bars}$

$=1059 \mathrm{~kJ} / \mathrm{kg}$

$=0.0007 \mathrm{~kg} / \mathrm{kg}$

$=0.00715 \mathrm{~kg} / \mathrm{kg}$

$=0.13$ for depths $<500 \mathrm{~m}$

$=0.13+0.0054($ depth -500$)$ for $500 \mathrm{~m}<$ depth $<550 \mathrm{~m}$

$=0.40$ for depths $>550 \mathrm{~m}$

$=0.00 \mathrm{~mm}$ for all depths

$=4.0 \mathrm{~W} / \mathrm{m}^{\circ}{ }^{\circ} \mathrm{C}$ 


\section{B.18 WELL B-3}

Well Geometry:

\begin{tabular}{|c|c|c|c|}
\hline $\begin{array}{c}\text { Vertical } \\
\text { Depth } \\
\text { (meters) }\end{array}$ & $\begin{array}{c}\text { Measured } \\
\text { Depth } \\
\text { (meters) }\end{array}$ & $\begin{array}{c}\text { Angle with } \\
\text { Vertical } \\
\text { (Degrees) }\end{array}$ & $\begin{array}{c}\text { Internal } \\
\text { Diameter } \\
(\mathrm{mm})\end{array}$ \\
\hline 433.7 & 433.7 & 0.000 & 315 \\
\hline 847.1 & 851.6 & 8.416 & 315 \\
\hline 1310.0 & 1329.8 & 14.533 & 221 \\
\hline
\end{tabular}

Stable Temperature Profile:

\begin{tabular}{|c|c|}
\hline $\begin{array}{c}\text { Vertical Depth } \\
\text { (meters) }\end{array}$ & $\begin{array}{c}\text { Temperature } \\
\text { (Degrees Celsius) }\end{array}$ \\
\hline 0 & 27 \\
1310 & 228 \\
\hline
\end{tabular}

\section{Other Model Input Parameters:}

Discharge rate

Pressure at $1310.0 \mathrm{mTVD}$

Flowing enthalpy at 1310.0 mTVD

Fluid (liquid + steam) gas content at $1310.0 \mathrm{mTVD}=0.0023 \mathrm{~kg} / \mathrm{kg}$

Fluid (liquid + steam) salinity at 1310.0 mTVD

Hughmark parameter, $\eta$

Roughness factor, $\varepsilon$

Effective thermal conductivity, $\kappa$

$$
=36.5 \mathrm{~kg} / \mathrm{s}
$$

$=26.85$ bars

$=2278 \mathrm{~kJ} / \mathrm{kg}$

$=0.00062 \mathrm{~kg} / \mathrm{kg}$

$=0.75$ for depths $<800 \mathrm{~m}$

$=0.75-0.0045($ depth -800$)$ for $800 \mathrm{~m}<$ depth $<900 \mathrm{~m}$

$=0.30$ for depths $>900 \mathrm{~m}$

$=0.00 \mathrm{~mm}$ for all depths

$=4.0 \mathrm{~W} / \mathrm{m}^{-}{ }^{\circ} \mathrm{C}$ 


\section{B.19 WELL B-4}

\section{Well Geometry:}

\begin{tabular}{|c|c|c|c|}
\hline $\begin{array}{c}\text { Vertical } \\
\text { Depth } \\
\text { (meters) }\end{array}$ & $\begin{array}{c}\text { Measured } \\
\text { Depth } \\
\text { (meters) }\end{array}$ & $\begin{array}{c}\text { Angle with } \\
\text { Vertical } \\
\text { (Degrees) }\end{array}$ & $\begin{array}{c}\text { Internal } \\
\text { Diameter } \\
(\mathrm{mm})\end{array}$ \\
\hline 445.3 & 445.3 & 0.000 & 221 \\
\hline 845.2 & 848.0 & 6.760 & 221 \\
\hline
\end{tabular}

\section{Stable Temperature Profile:}

\begin{tabular}{|c|c|}
\hline $\begin{array}{c}\text { Vertical Depth } \\
\text { (meters) }\end{array}$ & $\begin{array}{c}\text { Temperature } \\
\text { (Degrees Celsius) }\end{array}$ \\
\hline 0 & 27 \\
845 & 226 \\
\hline
\end{tabular}

\section{Other Model Input Parameters:}

Discharge rate

Pressure at $845.2 \mathrm{mTVD}$

Flowing enthalpy at $845.2 \mathrm{mTVD}$

Fluid (liquid + steam) gas content at 845.2 mTVD

Fluid (liquid + steam) salinity at 845.2 mTVD

Hughmark parameter, $\eta$

Roughness factor, $\varepsilon$

Effective thermal conductivity, $\kappa$
$=17.8 \mathrm{~kg} / \mathrm{s}$

$=25.84 \mathrm{bars}$

$=1572 \mathrm{~kJ} / \mathrm{kg}$

$=0.0022 \mathrm{~kg} / \mathrm{kg}$

$=0.0025 \mathrm{~kg} / \mathrm{kg}$

$=0.31$ for all depths

$=0.00 \mathrm{~mm}$ for all depths

$=4.0 \mathrm{~W} / \mathrm{m}-{ }^{\circ} \mathrm{C}$ 


\section{B.20 WELL B-5}

Well Geometry:

\begin{tabular}{|c|c|c|c|}
\hline $\begin{array}{c}\text { Vertical } \\
\text { Depth } \\
\text { (meters) }\end{array}$ & $\begin{array}{c}\text { Measured } \\
\text { Depth } \\
\text { (meters) }\end{array}$ & $\begin{array}{c}\text { Angle with } \\
\text { Vertical } \\
\text { (Degrees) }\end{array}$ & $\begin{array}{c}\text { Internal } \\
\text { Diameter } \\
(\mathrm{mm})\end{array}$ \\
\hline 415.1 & 415.1 & 0.000 & 221 \\
\hline 843.7 & 851.3 & 10.711 & 221 \\
\hline
\end{tabular}

Stable Temperature Profile:

\begin{tabular}{|c|c|}
\hline $\begin{array}{c}\text { Vertical Depth } \\
\text { (meters) }\end{array}$ & $\begin{array}{c}\text { Temperature } \\
\text { (Degrees Celsius) }\end{array}$ \\
\hline 0 & 27 \\
850 & 215 \\
\hline
\end{tabular}

\section{Other Model Input Parameters:}

Discharge rate

Pressure at $843.7 \mathrm{mTVD}$

Flowing enthalpy at 843.7 mTVD

Fluid (liquid + steam) gas content at 843.7 mTVD

Fluid (liquid + steam) salinity at $843.7 \mathrm{mTVD}$

Hughmark parameter, $\eta$

Roughness factor, $\varepsilon$

Effective thermal conductivity, $\kappa$
$=38.8 \mathrm{~kg} / \mathrm{s}$

$=20.72 \mathrm{bars}$

$=1215 \mathrm{~kJ} / \mathrm{kg}$

$=0.001 \mathrm{~kg} / \mathrm{kg}$

$=0.0043 \mathrm{~kg} / \mathrm{kg}$

$=0.02$ for depths $<450 \mathrm{~m}$

$=0.02+0.0064($ depth -450$)$ for $450 \mathrm{~m}<$ depth $<500 \mathrm{~m}$

$=0.34$ for depths $>500 \mathrm{~m}$

$=0.00 \mathrm{~mm}$ for all depths

$=4.0 \mathrm{~W} / \mathrm{m}^{-}{ }^{\circ} \mathrm{C}$ 


\section{B.21 WELL B-13}

\section{Well Geometry:}

\begin{tabular}{|c|c|c|c|}
\hline $\begin{array}{c}\text { Vertical } \\
\text { Depth } \\
\text { (meters) }\end{array}$ & $\begin{array}{c}\text { Measured } \\
\text { Depth } \\
\text { (meters) }\end{array}$ & $\begin{array}{c}\text { Angle with } \\
\text { Vertical } \\
\text { (Degrees) }\end{array}$ & $\begin{array}{c}\text { Internal } \\
\text { Diameter } \\
(\mathrm{mm})\end{array}$ \\
\hline 155.4 & 155.4 & 0.000 & 221 \\
\hline 805.9 & 812.0 & 7.816 & 221 \\
\hline
\end{tabular}

Stable Temperature Profile:

\begin{tabular}{|c|c|}
\hline $\begin{array}{c}\text { Vertical Depth } \\
\text { (meters) }\end{array}$ & $\begin{array}{c}\text { Temperature } \\
\text { (Degrees Celsius) }\end{array}$ \\
\hline 0 & 27 \\
806 & 200 \\
\hline
\end{tabular}

\section{Other Model Input Parameters:}

Discharge rate

Pressure at 805.9 mTVD

Flowing enthalpy at $805.9 \mathrm{mTVD}$

Fluid (liquid + steam) gas content at 805.9 mTVD

Fluid (liquid + steam) salinity at 805.9 mTVD

Hughmark parameter, $\eta$

Roughness factor, $\varepsilon$

Effective thermal conductivity, $\kappa$
$=11.0 \mathrm{~kg} / \mathrm{s}$

$=14.81 \mathrm{bars}$

$=1566 \mathrm{~kJ} / \mathrm{kg}$

$=0.0025 \mathrm{~kg} / \mathrm{kg}$

$=0.00051 \mathrm{~kg} / \mathrm{kg}$

$=0.25$ for depths $<350 \mathrm{~m}$

$=0.25-0.001($ depth -350$)$ for $350 \mathrm{~m}<$ depth $<400 \mathrm{~m}$

$=0.20$ for depths $>400 \mathrm{~m}$

$=0.00 \mathrm{~mm}$ for all depths

$=4.0 \mathrm{~W} / \mathrm{m}^{\circ}{ }^{\circ} \mathrm{C}$ 


\section{B.22 WELL C-1}

Well Geometry:

\begin{tabular}{|c|c|c|c|}
\hline $\begin{array}{c}\text { Vertical } \\
\text { Depth } \\
\text { (meters) }\end{array}$ & $\begin{array}{c}\text { Measured } \\
\text { Depth } \\
\text { (meters) }\end{array}$ & $\begin{array}{c}\text { Angle with } \\
\text { Vertical } \\
\text { (Degrees) }\end{array}$ & $\begin{array}{c}\text { Internal } \\
\text { Diameter } \\
(\mathrm{mm})\end{array}$ \\
\hline 244.4 & 244.4 & 0.000 & 221 \\
\hline 818.0 & 818.1 & 1.070 & 221 \\
\hline
\end{tabular}

Stable Temperature Profile:

\begin{tabular}{|c|c|}
\hline $\begin{array}{c}\text { Vertical Depth } \\
\text { (meters) }\end{array}$ & $\begin{array}{c}\text { Temperature } \\
\text { (Degrees Celsius) }\end{array}$ \\
\hline 0 & 27 \\
818 & 200 \\
\hline
\end{tabular}

\section{Other Model Input Parameters:}

Discharge rate

Pressure at $818.0 \mathrm{mTVD}$

Flowing enthalpy at $818.0 \mathrm{mTVD}$

Fluid (liquid + steam) gas content at $818.0 \mathrm{mTVD}$

Fluid (liquid + steam) salinity at $818.0 \mathrm{mTVD}$

Hughmark parameter, $\eta$

Roughness factor, $\varepsilon$

Effective thermal conductivity, $\kappa$
$=18.3 \mathrm{~kg} / \mathrm{s}$

$=15.58 \mathrm{bars}$

$=1797 \mathrm{~kJ} / \mathrm{kg}$

$=0.0003 \mathrm{~kg} / \mathrm{kg}$

$=0.0025 \mathrm{~kg} / \mathrm{kg}$

$=0.44$ for depths $<450 \mathrm{~m}$

$=0.44-0.0004($ depth -450$)$ for $450 \mathrm{~m}<$ depth $<500 \mathrm{~m}$

$=0.42$ for depths $>500 \mathrm{~m}$

$=0.00 \mathrm{~mm}$ for all depths

$=4.0 \mathrm{~W} / \mathrm{m}-{ }^{\circ} \mathrm{C}$ 


\section{B.23 WELL C-2}

\section{Well Geometry:}

\begin{tabular}{|c|c|c|c|}
\hline $\begin{array}{c}\text { Vertical } \\
\text { Depth } \\
\text { (meters) }\end{array}$ & $\begin{array}{c}\text { Measured } \\
\text { Depth } \\
\text { (meters) }\end{array}$ & $\begin{array}{c}\text { Angle with } \\
\text { Vertical } \\
\text { (Degrees) }\end{array}$ & $\begin{array}{c}\text { Internal } \\
\text { Diameter } \\
(\mathrm{mm})\end{array}$ \\
\hline 587.3 & 587.3 & 0.000 & 221 \\
\hline
\end{tabular}

\section{Stable Temperature Profile:}

\begin{tabular}{|c|c|}
\hline $\begin{array}{c}\text { Vertical Depth } \\
\text { (meters) }\end{array}$ & $\begin{array}{c}\text { Temperature } \\
\text { (Degrees Celsius) }\end{array}$ \\
\hline 0 & 27 \\
\hline 590 & 197 \\
\hline
\end{tabular}

\section{Other Model Input Parameters:}

Discharge rate

Pressure at $587.3 \mathrm{mTVD}$

Flowing enthalpy at 587.3 mTVD

Fluid (liquid + steam) gas content at 587.3 mTVD

Fluid (liquid + steam) salinity at $587.3 \mathrm{mTVD}$

Hughmark parameter, $\eta$

Roughness factor, $\varepsilon$

Effective thermal conductivity, $\kappa$
$=14.6 \mathrm{~kg} / \mathrm{s}$

$=14.58 \mathrm{bars}$

$=2036 \mathrm{~kJ} / \mathrm{kg}$

$=0.017 \mathrm{~kg} / \mathrm{kg}$

$=0.0022 \mathrm{~kg} / \mathrm{kg}$

$=0.67$ for depths $<250 \mathrm{~m}$

$=0.67-0.0044($ depth -250$)$ for $250 \mathrm{~m}<$ depth $<300 \mathrm{~m}$

$=0.45$ for depths $>300 \mathrm{~m}$

$=0.00 \mathrm{~mm}$ for all depths

$=4.0 \mathrm{~W} / \mathrm{m}^{-}{ }^{\circ} \mathrm{C}$ 


\section{B.24 WELL C-3}

Well Geometry:

\begin{tabular}{|c|c|c|c|}
\hline $\begin{array}{c}\text { Vertical } \\
\text { Depth } \\
\text { (meters) }\end{array}$ & $\begin{array}{c}\text { Measured } \\
\text { Depth } \\
\text { (meters) }\end{array}$ & $\begin{array}{c}\text { Angle with } \\
\text { Vertical } \\
\text { (Degrees) }\end{array}$ & $\begin{array}{c}\text { Internal } \\
\text { Diameter } \\
(\mathrm{mm})\end{array}$ \\
\hline 720.0 & 720.0 & 0.000 & 320 \\
\hline
\end{tabular}

Stable Temperature Profile:

\begin{tabular}{|c|c|}
\hline $\begin{array}{c}\text { Vertical Depth } \\
\text { (meters) }\end{array}$ & $\begin{array}{c}\text { Temperature } \\
\text { (Degrees Celsius) }\end{array}$ \\
\hline 0 & 27 \\
892 & 196 \\
\hline
\end{tabular}

\section{Other Model Input Parameters:}

Discharge rate

Pressure at $720.0 \mathrm{mTVD}$

Flowing enthalpy at $720.0 \mathrm{mTVD}$

Fluid (liquid + steam) gas content at 720.0 mTVD

Fluid (liquid + steam) salinity at 720.0 mTVD

Hughmark parameter, $\eta$

Roughness factor, $\varepsilon$

Effective thermal conductivity, $\kappa$
$=19.7 \mathrm{~kg} / \mathrm{s}$

$=13.58 \mathrm{bars}$

$=1893 \mathrm{~kJ} / \mathrm{kg}$

$=0.0007 \mathrm{~kg} / \mathrm{kg}$

$=0.0023 \mathrm{~kg} / \mathrm{kg}$

$=0.34$ for depths $<350 \mathrm{~m}$

$=0.34+0.0004($ depth -350$)$ for $350 \mathrm{~m}<$ depth $<400 \mathrm{~m}$

$=0.36$ for depths $>400 \mathrm{~m}$

$=0.00 \mathrm{~mm}$ for all depths

$=4.0 \mathrm{~W} / \mathrm{m}^{-}{ }^{\circ} \mathrm{C}$ 


\section{B.25 WELL C-4}

\section{Well Geometry:}

\begin{tabular}{|c|c|c|c|}
\hline $\begin{array}{c}\text { Vertical } \\
\text { Depth } \\
\text { (meters) }\end{array}$ & $\begin{array}{c}\text { Measured } \\
\text { Depth } \\
\text { (meters) }\end{array}$ & $\begin{array}{c}\text { Angle with } \\
\text { Vertical } \\
\text { (Degrees) }\end{array}$ & $\begin{array}{c}\text { Internal } \\
\text { Diameter } \\
(\mathrm{mm})\end{array}$ \\
\hline 438.9 & 438.9 & 0.000 & 320 \\
\hline 730.6 & 737.6 & 12.429 & 320 \\
\hline
\end{tabular}

Stable Temperature Profile:

\begin{tabular}{|c|c|}
\hline $\begin{array}{c}\text { Vertical Depth } \\
\text { (meters) }\end{array}$ & $\begin{array}{c}\text { Temperature } \\
\text { (Degrees Celsius) }\end{array}$ \\
\hline 0 & 27 \\
740 & 197 \\
\hline
\end{tabular}

\section{Other Model Input Parameters:}

Discharge rate

Pressure at $730.6 \mathrm{mTVD}$

Flowing enthalpy at 730.6 mTVD

Fluid (liquid + steam) gas content at $730.6 \mathrm{mTVD}$

Fluid (liquid + steam) salinity at 730.6 mTVD

Hughmark parameter, $\eta$

Roughness factor, $\varepsilon$

Effective thermal conductivity, $\kappa$
$=22.0 \mathrm{~kg} / \mathrm{s}$

$=14.65 \mathrm{bars}$

$=2105 \mathrm{~kJ} / \mathrm{kg}$

$=0.0009 \mathrm{~kg} / \mathrm{kg}$

$=0.00145 \mathrm{~kg} / \mathrm{kg}$

$=0.54$ for depths $<350 \mathrm{~m}$

$=0.54+0.0004($ depth -350$)$ for $350 \mathrm{~m}<$ depth $<400 \mathrm{~m}$

$=0.56$ for depths $>400 \mathrm{~m}$

$=0.00 \mathrm{~mm}$ for all depths

$=4.0 \mathrm{~W} / \mathrm{m}^{-}{ }^{\circ} \mathrm{C}$ 


\section{B.26 WELL C-5}

Well Geometry:

\begin{tabular}{|c|c|c|c|}
\hline $\begin{array}{c}\text { Vertical } \\
\text { Depth } \\
\text { (meters) }\end{array}$ & $\begin{array}{c}\text { Measured } \\
\text { Depth } \\
\text { (meters) }\end{array}$ & $\begin{array}{c}\text { Angle with } \\
\text { Vertical } \\
\text { (Degrees) }\end{array}$ & $\begin{array}{c}\text { Internal } \\
\text { Diameter } \\
(\mathrm{mm})\end{array}$ \\
\hline 439.2 & 439.2 & 0.000 & 320 \\
\hline 843.2 & 851.6 & 11.584 & 320 \\
\hline
\end{tabular}

Stable Temperature Profile:

\begin{tabular}{|c|c|}
\hline $\begin{array}{c}\text { Vertical Depth } \\
\text { (meters) }\end{array}$ & $\begin{array}{c}\text { Temperature } \\
\text { (Degrees Celsius) }\end{array}$ \\
\hline 0 & 27 \\
850 & 212 \\
\hline
\end{tabular}

\section{Other Model Input Parameters:}

Discharge rate

Pressure at $843.2 \mathrm{mTVD}$

Flowing enthalpy at $843.2 \mathrm{mTVD}$

Fluid (liquid + steam) gas content at 843.2 mTVD

Fluid (liquid + steam) salinity at $843.2 \mathrm{mTVD}$

Hughmark parameter, $\eta$

Roughness factor, $\varepsilon$

Effective thermal conductivity, $\kappa$
$=39.4 \mathrm{~kg} / \mathrm{s}$

$=19.63 \mathrm{bars}$

$=1825 \mathrm{~kJ} / \mathrm{kg}$

$=0.0002 \mathrm{~kg} / \mathrm{kg}$

$=0.0030 \mathrm{~kg} / \mathrm{kg}$

$=0.59-0.0002($ depth $)$ for depths $<450 \mathrm{~m}$

$=0.50$ for depths $>450 \mathrm{~m}$

$=0.00 \mathrm{~mm}$ for all depths

$=4.0 \mathrm{~W} / \mathrm{m}^{-}{ }^{\circ} \mathrm{C}$ 


\section{B.27 WELL C-6}

\section{Well Geometry:}

\begin{tabular}{|c|c|c|c|}
\hline $\begin{array}{c}\text { Vertical } \\
\text { Depth } \\
\text { (meters) }\end{array}$ & $\begin{array}{c}\text { Measured } \\
\text { Depth } \\
\text { (meters) }\end{array}$ & $\begin{array}{c}\text { Angle with } \\
\text { Vertical } \\
\text { (Degrees) }\end{array}$ & $\begin{array}{c}\text { Internal } \\
\text { Diameter } \\
(\mathrm{mm})\end{array}$ \\
\hline 484.6 & 484.6 & 0.000 & 217 \\
\hline 1004.5 & 1025.0 & 15.832 & 217 \\
\hline
\end{tabular}

Stable Temperature Profile:

\begin{tabular}{|c|c|}
\hline $\begin{array}{c}\text { Vertical Depth } \\
\text { (meters) }\end{array}$ & $\begin{array}{c}\text { Temperature } \\
\text { (Degrees Celsius) }\end{array}$ \\
\hline 0 & 20 \\
\hline 1005 & 240 \\
\hline
\end{tabular}

\section{Other Model Input Parameters:}

Discharge rate

Pressure at 1004.5 mTVD

Flowing enthalpy at $1004.5 \mathrm{mTVD}$

Fluid (liquid + steam) gas content at $1004.5 \mathrm{mTVD}=0.00059 \mathrm{~kg} / \mathrm{kg}$

Fluid (liquid + steam) salinity at 1004.5 mTVD

Hughmark parameter, $\eta$

Roughness factor, $\varepsilon$

$$
\begin{aligned}
& =64.9 \mathrm{~kg} / \mathrm{s} \\
& =30.98 \mathrm{bars} \\
& =1110 \mathrm{~kJ} / \mathrm{kg} \\
& =0.00059 \mathrm{~kg} / \mathrm{kg} \\
& =0.002415 \mathrm{~kg} / \mathrm{kg} \\
& =0.00 \text { for depths }<400 \mathrm{~m} \\
& =0.00+0.016(\text { depth }-400) \text { for } \\
& \quad \quad 400 \mathrm{~m}<\text { depth }<450 \mathrm{~m} \\
& =0.80 \text { for depths }>450 \mathrm{~m} \\
& =0.00 \text { mm for all depths }
\end{aligned}
$$




\section{B.28 WELL CS-1}

Well Geometry:

\begin{tabular}{|c|c|c|c|}
\hline $\begin{array}{c}\text { Vertical } \\
\text { Depth } \\
\text { (meters) }\end{array}$ & $\begin{array}{c}\text { Measured } \\
\text { Depth } \\
\text { (meters) }\end{array}$ & $\begin{array}{c}\text { Angle with } \\
\text { Vertical } \\
\text { (Degrees) }\end{array}$ & $\begin{array}{c}\text { Internal } \\
\text { Diameter } \\
(\mathrm{mm})\end{array}$ \\
\hline 237.7 & 237.7 & 0.000 & 315 \\
\hline 679.8 & 680.6 & 3.444 & 315 \\
\hline
\end{tabular}

Stable Temperature Profile:

\begin{tabular}{|c|c|}
\hline $\begin{array}{c}\text { Vertical Depth } \\
\text { (meters) }\end{array}$ & $\begin{array}{c}\text { Temperature } \\
\text { (Degrees Celsius) }\end{array}$ \\
\hline 0 & 20 \\
\hline 680 & 175 \\
\hline
\end{tabular}

\section{Other Model Input Parameters:}

Discharge rate

Pressure at $679.8 \mathrm{mTVD}$

Flowing enthalpy at $679.8 \mathrm{mTVD}$

Fluid (liquid + steam) gas content at 679.8 mTVD

Fluid (liquid + steam) salinity at $679.8 \mathrm{mTVD}$

Hughmark parameter, $\eta$

Roughness factor, $\varepsilon$

Effective thermal conductivity, $\kappa$
$=22.3 \mathrm{~kg} / \mathrm{s}$

$=8.92 \mathrm{bars}$

$=1058 \mathrm{~kJ} / \mathrm{kg}$

$=0.00356 \mathrm{~kg} / \mathrm{kg}$

$=0.00897 \mathrm{~kg} / \mathrm{kg}$

$=0.33$ for depths $<250 \mathrm{~m}$

$=0.33-0.0004($ depth -250$)$ for $250 \mathrm{~m}<$ depth $<300 \mathrm{~m}$

$=0.31$ for depths $>300 \mathrm{~m}$

$=0.00 \mathrm{~mm}$ for all depths

$=4.0 \mathrm{~W} / \mathrm{m}^{-}{ }^{\circ} \mathrm{C}$ 


\section{B.29 WELL KE1-4}

Well Geometry:

\begin{tabular}{|c|c|c|c|}
\hline $\begin{array}{c}\text { Vertical } \\
\text { Depth } \\
\text { (meters) }\end{array}$ & $\begin{array}{c}\text { Measured } \\
\text { Depth } \\
\text { (meters) }\end{array}$ & $\begin{array}{c}\text { Angle with } \\
\text { Vertical } \\
\text { (Degrees) }\end{array}$ & $\begin{array}{c}\text { Internal } \\
\text { Diameter } \\
(\mathrm{mm})\end{array}$ \\
\hline 1260.4 & 1260.4 & 0.000 & 102 \\
\hline
\end{tabular}

Stable Temperature Profile:

\begin{tabular}{|c|c|}
\hline $\begin{array}{c}\text { Vertical Depth } \\
\text { (meters) }\end{array}$ & $\begin{array}{c}\text { Temperature } \\
\text { (Degrees Celsius) }\end{array}$ \\
\hline 0 & 15 \\
470 & 35 \\
860 & 190 \\
1000 & 220 \\
1260 & 228 \\
\hline
\end{tabular}

\section{Other Model Input Parameters:}

\section{Discharge Test (November 12, 1983)}

Discharge rate

Pressure at $1260.4 \mathrm{mTVD}$

Temperature at $1260.4 \mathrm{mTVD}$

Fluid (liquid + steam) gas content at $1260.4 \mathrm{mTVD}=0.0000 \mathrm{~kg} / \mathrm{kg}$

Fluid (liquid + steam) salinity at 1260.4 mTVD

Hughmark parameter, $\eta$

Roughness factor, $\varepsilon$

Effective thermal conductivity, $\kappa$
$=7.08 \mathrm{~kg} / \mathrm{s}$

$=58.1 \mathrm{bars}$

$=227.3{ }^{\circ} \mathrm{C}$

$=0.0000 \mathrm{~kg} / \mathrm{kg}$

$=0.10$ for depths $<300 \mathrm{~m}$

$=0.10+0.018($ depth -300$)$ for $300 \mathrm{~m}<$ depth $<350 \mathrm{~m}$

$=1.00$ for depths $>350 \mathrm{~m}$

$=0.00 \mathrm{~mm}$ for all depths

$=1.3 \mathrm{~W} / \mathrm{m}-{ }^{\circ} \mathrm{C}$

\section{Discharge Test (November 13, 1983)}

Discharge rate

Pressure at $1260.4 \mathrm{mTVD}$

Temperature at $1260.4 \mathrm{mTVD}$

Fluid (liquid + steam) gas content at $1260.4 \mathrm{mTVD}=0.0000 \mathrm{~kg} / \mathrm{kg}$

Fluid (liquid + steam) salinity at $1260.4 \mathrm{mTVD} \quad=0.0000 \mathrm{~kg} / \mathrm{kg}$

Hughmark parameter, $\eta$

Roughness factor, $\varepsilon$

Effective thermal conductivity, $\kappa$
$=8.44 \mathrm{~kg} / \mathrm{s}$

$=57.75$ bars

$=227.45{ }^{\circ} \mathrm{C}$

$=0.01$ for depths $<450 \mathrm{~m}$

$=0.01+0.0198($ depth -450$)$ for $450 \mathrm{~m}<$ depth $<500 \mathrm{~m}$

$=1.00$ for depths $>500 \mathrm{~m}$

$=0.00 \mathrm{~mm}$ for all depths

$=0.8 \mathrm{~W} / \mathrm{m}^{-}{ }^{\circ} \mathrm{C}$ 


\section{B.30 WELL KE1-9}

Well Geometry:

\begin{tabular}{|c|c|c|c|}
\hline $\begin{array}{c}\text { Vertical } \\
\text { Depth } \\
\text { (meters) }\end{array}$ & $\begin{array}{c}\text { Measured } \\
\text { Depth } \\
\text { (meters) }\end{array}$ & $\begin{array}{c}\text { Angle with } \\
\text { Vertical } \\
\text { (Degrees) }\end{array}$ & $\begin{array}{c}\text { Internal } \\
\text { Diameter } \\
(\mathrm{mm})\end{array}$ \\
\hline 773.4 & 773.4 & 0.000 & 224 \\
\hline
\end{tabular}

Stable Temperature Profile:

\begin{tabular}{|c|c|}
\hline $\begin{array}{c}\text { Vertical Depth } \\
\text { (meters) }\end{array}$ & $\begin{array}{c}\text { Temperature } \\
\text { (Degrees Celsius) }\end{array}$ \\
\hline 0 & 20 \\
320 & 100 \\
600 & 190 \\
1230 & 240 \\
\hline
\end{tabular}

\section{Other Model Input Parameters:}

Discharge rate

Pressure at $773.4 \mathrm{mTVD}$

Flowing enthalpy at $773.4 \mathrm{mTVD}$

Fluid (liquid + steam) gas content at 773.4 mTVD

Fluid (liquid + steam) salinity at 773.4 mTVD

Hughmark parameter, $\eta$

Roughness factor, $\varepsilon$

Effective thermal conductivity, $\kappa$
$=17.2 \mathrm{~kg} / \mathrm{s}$

$=18.18 \mathrm{bars}$

$=1131 \mathrm{~kJ} / \mathrm{kg}$

$=0.0000 \mathrm{~kg} / \mathrm{kg}$

$=0.0000 \mathrm{~kg} / \mathrm{kg}$

$=0.21$ for depths $<300 \mathrm{~m}$

$=0.21+0.0148($ depth -300$)$ for $300 \mathrm{~m}<$ depth $<350 \mathrm{~m}$

$=0.95$ for depths $>350 \mathrm{~m}$

$=0.00 \mathrm{~mm}$ for all depths

$=4 \mathrm{~W} / \mathrm{m}-{ }^{\circ} \mathrm{C}$ 


\section{B.31 WELL KE1-11}

\section{Well Geometry:}

\begin{tabular}{|c|c|c|c|}
\hline $\begin{array}{c}\text { Vertical } \\
\text { Depth } \\
\text { (meters) }\end{array}$ & $\begin{array}{c}\text { Measured } \\
\text { Depth } \\
\text { (meters) }\end{array}$ & $\begin{array}{c}\text { Angle with } \\
\text { Vertical } \\
\text { (Degrees) }\end{array}$ & $\begin{array}{c}\text { Internal } \\
\text { Diameter } \\
(\mathrm{mm})\end{array}$ \\
\hline 980.9 & 980.9 & 0.000 & 224 \\
\hline
\end{tabular}

\section{Stable Temperature Profile:}

\begin{tabular}{|c|c|}
\hline $\begin{array}{c}\text { Vertical Depth } \\
\text { (meters) }\end{array}$ & $\begin{array}{c}\text { Temperature } \\
\text { (Degrees Celsius) }\end{array}$ \\
\hline 0 & 10 \\
480 & 100 \\
1000 & 255 \\
\hline
\end{tabular}

\section{Other Model Input Parameters:}

Discharge rate

Pressure at $980.9 \mathrm{mTVD}$

Flowing enthalpy at 980.9 mTVD

Fluid (liquid + steam) gas content at 980.9 mTVD

Fluid (liquid + steam) salinity at 980.9 mTVD

Hughmark parameter, $\eta$

Roughness factor, $\varepsilon$

Effective thermal conductivity, $\kappa$
$=18.5 \mathrm{~kg} / \mathrm{s}$

$=42.43 \mathrm{bars}$

$=1150 \mathrm{~kJ} / \mathrm{kg}$

$=0.0000 \mathrm{~kg} / \mathrm{kg}$

$=0.0000 \mathrm{~kg} / \mathrm{kg}$

$=0.65$ for depths $<550 \mathrm{~m}$

$=0.65-0.006($ depth -550$)$ for $550 \mathrm{~m}<$ depth $<600 \mathrm{~m}$

$=0.35$ for depths $>600 \mathrm{~m}$

$=0.00 \mathrm{~mm}$ for all depths

$=4 \mathrm{~W} / \mathrm{m}-{ }^{\circ} \mathrm{C}$ 


\section{B.32 WELL KE1-17}

Well Geometry:

\begin{tabular}{|c|c|c|c|}
\hline $\begin{array}{c}\text { Vertical } \\
\text { Depth } \\
\text { (meters) }\end{array}$ & $\begin{array}{c}\text { Measured } \\
\text { Depth } \\
\text { (meters) }\end{array}$ & $\begin{array}{c}\text { Angle with } \\
\text { Vertical } \\
\text { (Degrees) }\end{array}$ & $\begin{array}{c}\text { Internal } \\
\text { Diameter } \\
(\mathrm{mm})\end{array}$ \\
\hline 200.0 & 200.0 & 0.000 & 224 \\
848.1 & 858.7 & 10.293 & 224 \\
\hline
\end{tabular}

Stable Temperature Profile:

\begin{tabular}{|c|c|}
\hline $\begin{array}{c}\text { Vertical Depth } \\
\text { (meters) }\end{array}$ & $\begin{array}{c}\text { Temperature } \\
\text { (Degrees Celsius) }\end{array}$ \\
\hline 0 & 18 \\
350 & 35 \\
850 & 214 \\
\hline
\end{tabular}

\section{Other Model Input Parameters:}

\section{Discharge Test (March 30, 1986)}

Discharge rate

Pressure at $848.1 \mathrm{mTVD}$

$=41.8 \mathrm{~kg} / \mathrm{s}$

Flowing enthalpy at $848.1 \mathrm{mTVD}$

$=25.93$ bars

Fluid (liquid + steam) gas content at $848.1 \mathrm{mTVD}$

$=1000 \mathrm{~kJ} / \mathrm{kg}$

Fluid (liquid + steam) salinity at 848.1 mTVD

$=0.0000 \mathrm{~kg} / \mathrm{kg}$

Hughmark parameter, $\eta$

$=0.0000 \mathrm{~kg} / \mathrm{kg}$

$=0.40$ for depths $<500 \mathrm{~m}$

$=0.40+0.012($ depth -500$)$ for $500 \mathrm{~m}<$ depth $<550 \mathrm{~m}$

Roughness factor, $\varepsilon$

$=1.00$ for depths $>550 \mathrm{~m}$

$=0.00 \mathrm{~mm}$ for depths $<550 \mathrm{~m}$

$=7.00 \mathrm{~mm}$ for depths $>550 \mathrm{~m}$

Effective thermal conductivity, $\kappa$

$$
=4 \mathrm{~W} / \mathrm{m}-{ }^{\circ} \mathrm{C}
$$

\section{Discharge Test (April 4, 1986)}

Discharge rate

Pressure at $848.1 \mathrm{mTVD}$

$=25.8 \mathrm{~kg} / \mathrm{s}$

$=26.07 \mathrm{bars}$

Flowing enthalpy at 848.1 mTVD

$=1000 \mathrm{~kJ} / \mathrm{kg}$

Fluid (liquid + steam) gas content at 848.1 mTVD

Fluid (liquid + steam) salinity at 848.1 mTVD

$=0.0000 \mathrm{~kg} / \mathrm{kg}$

Hughmark parameter, $\eta$

$=0.0000 \mathrm{~kg} / \mathrm{kg}$

$=0.85$ for depths $<450 \mathrm{~m}$

$=0.85+0.003($ depth -450$)$ for $450 \mathrm{~m}<$ depth $<500 \mathrm{~m}$

Roughness factor, $\varepsilon$

$=1.00$ for depths $>500 \mathrm{~m}$

$=0.00 \mathrm{~mm}$ for depths $<500 \mathrm{~m}$

$=10.00 \mathrm{~mm}$ for depths $>500 \mathrm{~m}$

Effective thermal conductivity, $\kappa$

$=4 \mathrm{~W} / \mathrm{m}-{ }^{\circ} \mathrm{C}$ 


\section{B.33 WELL KE1-19S}

\section{Well Geometry:}

\begin{tabular}{|c|c|c|c|}
\hline $\begin{array}{c}\text { Vertical } \\
\text { Depth } \\
\text { (meters) }\end{array}$ & $\begin{array}{c}\text { Measured } \\
\text { Depth } \\
\text { (meters) }\end{array}$ & $\begin{array}{c}\text { Angle with } \\
\text { Vertical } \\
\text { (Degrees) }\end{array}$ & $\begin{array}{c}\text { Internal } \\
\text { Diameter } \\
(\mathrm{mm})\end{array}$ \\
\hline 94.0 & 94.0 & 0.000 & 159 \\
\hline 734.9 & 740.2 & 7.343 & 159 \\
\hline
\end{tabular}

Stable Temperature Profile:

\begin{tabular}{|c|c|}
\hline $\begin{array}{c}\text { Vertical Depth } \\
\text { (meters) }\end{array}$ & $\begin{array}{c}\text { Temperature } \\
\text { (Degrees Celsius) }\end{array}$ \\
\hline 0 & 20 \\
405 & 100 \\
740 & 180 \\
\hline
\end{tabular}

\section{Other Model Input Parameters:}

\section{Discharge Test (September 1, 1986)}

Discharge rate

Pressure at 734.9 mTVD

$$
\begin{aligned}
& =23.9 \mathrm{~kg} / \mathrm{s} \\
& =19.01 \mathrm{bars}
\end{aligned}
$$

Flowing enthalpy at 734.9 mTVD

$=1000 \mathrm{~kJ} / \mathrm{kg}$

Fluid (liquid + steam) gas content at 734.9 mTVD $=0.0000 \mathrm{~kg} / \mathrm{kg}$

Fluid (liquid + steam) salinity at $734.9 \mathrm{mTVD} \quad=0.0000 \mathrm{~kg} / \mathrm{kg}$

Hughmark parameter, $\eta$

$=0.05$ for depths $<350 \mathrm{~m}$

$=0.05+0.017($ depth -350$)$ for $350 \mathrm{~m}<$ depth $<400 \mathrm{~m}$

Roughness factor, $\varepsilon$

$=0.90$ for depths $>400 \mathrm{~m}$

Effective thermal conductivity, $\kappa$

$=0.00 \mathrm{~mm}$ for all depths

$=4 \mathrm{~W} / \mathrm{m}-{ }^{\circ} \mathrm{C}$

Discharge Test (September 16, 1986)

Discharge rate

Pressure at $734.9 \mathrm{mTVD}$

$=14.5 \mathrm{~kg} / \mathrm{s}$

$=19.42 \mathrm{bars}$

Flowing enthalpy at 734.9 mTVD

$=1000 \mathrm{~kJ} / \mathrm{kg}$

Fluid (liquid + steam) gas content at 734.9 mTVD

$=0.0000 \mathrm{~kg} / \mathrm{kg}$

Fluid (liquid + steam) salinity at 734.9 mTVD

$=0.0000 \mathrm{~kg} / \mathrm{kg}$

Hughmark parameter, $\eta$

$=0.35$ for depths $<200 \mathrm{~m}$

$=0.35+0.013($ depth -200$)$ for $200 \mathrm{~m}<$ depth $<250 \mathrm{~m}$

Roughness factor, $\varepsilon$

Effective thermal conductivity, $\kappa$

$=1.00$ for depths $>250 \mathrm{~m}$

$=0.00 \mathrm{~mm}$ for all depths

$=4 \mathrm{~W} / \mathrm{m}-{ }^{\circ} \mathrm{C}$ 


\section{B.34 WELL KE1-22:}

Well Geometry:

\begin{tabular}{|c|c|c|c|}
\hline $\begin{array}{c}\text { Vertical } \\
\text { Depth } \\
\text { (meters) }\end{array}$ & $\begin{array}{c}\text { Measured } \\
\text { Depth } \\
\text { (meters) }\end{array}$ & $\begin{array}{c}\text { Angle with } \\
\text { Vertical } \\
\text { (Degrees) }\end{array}$ & $\begin{array}{c}\text { Internal } \\
\text { Diameter } \\
(\mathrm{mm})\end{array}$ \\
\hline 873.9 & 875.0 & 2.873 & 224 \\
\hline
\end{tabular}

Stable Temperature Profile:

\begin{tabular}{|c|c|}
\hline $\begin{array}{c}\text { Vertical Depth } \\
\text { (meters) }\end{array}$ & $\begin{array}{c}\text { Temperature } \\
\text { (Degrees Celsius) }\end{array}$ \\
\hline 0 & 20 \\
900 & 220 \\
\hline
\end{tabular}

\section{Other Model Input Parameters:}

Discharge Test (February 10, 1987)

Discharge rate

Pressure at $873.9 \mathrm{mTVD}$

Flowing enthalpy at 873.9 mTVD

Fluid (liquid + steam) gas content at 873.9 mTVD

Fluid (liquid + steam) salinity at 873.9 mTVD

Hughmark parameter, $\eta$

Roughness factor, $\varepsilon$

Effective thermal conductivity, $\kappa$
$=25.0 \mathrm{~kg} / \mathrm{s}$

$=30.42 \mathrm{bars}$

$=995 \mathrm{~kJ} / \mathrm{kg}$

$=0.0000 \mathrm{~kg} / \mathrm{kg}$

$=0.0000 \mathrm{~kg} / \mathrm{kg}$

$=1.00$ for all depths

$=0.00 \mathrm{~mm}$ for all depths

$=4 \mathrm{~W} / \mathrm{m}-{ }^{\circ} \mathrm{C}$

$=48.0 \mathrm{~kg} / \mathrm{s}$

$=29.71 \mathrm{bars}$

$=995 \mathrm{~kJ} / \mathrm{kg}$

Flowing enthalpy at $734.9 \mathrm{mTVD}$

$=0.0000 \mathrm{~kg} / \mathrm{kg}$

$=0.0000 \mathrm{~kg} / \mathrm{kg}$

$=0.40$ for depths $<250 \mathrm{~m}$

$=0.40+0.012($ depth -250$)$ for $250 \mathrm{~m}<$ depth $<300 \mathrm{~m}$

$=1.00$ for depths $>300 \mathrm{~m}$

$=0.00 \mathrm{~mm}$ for all depths

$=4 \mathrm{~W} / \mathrm{m}-{ }^{\circ} \mathrm{C}$ 


\section{B.35 WELL GH-11}

Well Geometry:

\begin{tabular}{|c|c|c|c|}
\hline $\begin{array}{c}\text { Vertical } \\
\text { Depth } \\
\text { (meters) }\end{array}$ & $\begin{array}{c}\text { Measured } \\
\text { Depth } \\
\text { (meters) }\end{array}$ & $\begin{array}{c}\text { Angle with } \\
\text { Vertical } \\
\text { (Degrees) }\end{array}$ & $\begin{array}{c}\text { Internal } \\
\text { Diameter } \\
(\mathrm{mm})\end{array}$ \\
\hline 298.3 & 300.0 & 6.102 & 253 \\
\hline 654.5 & 700.0 & 27.064 & 253 \\
\hline
\end{tabular}

Stable Temperature Profile:

\begin{tabular}{|c|c|}
\hline $\begin{array}{c}\text { Vertical Depth } \\
\text { (meters) }\end{array}$ & $\begin{array}{c}\text { Temperature } \\
\text { (Degrees Celsius) }\end{array}$ \\
\hline 0 & 10 \\
400 & 195 \\
800 & 210 \\
\hline
\end{tabular}

\section{Other Model Input Parameters:}

\section{Discharge Test (July 19, 1991)}

Discharge rate

Pressure at $654.5 \mathrm{mTVD}$

Flowing enthalpy at $654.5 \mathrm{mTVD}$

Fluid (liquid + steam) gas content at $654.5 \mathrm{mTVD}$

Fluid (liquid + steam) salinity at 654.5 mTVD

Hughmark parameter, $\eta$

Roughness factor, $\varepsilon$

Effective thermal conductivity, $\kappa$

Discharge Test (July 20, 1991)

Discharge rate

Pressure at $654.5 \mathrm{mTVD}$

Flowing enthalpy at 654.5 mTVD

Fluid (liquid + steam) gas content at $654.5 \mathrm{mTVD}$

Fluid (liquid + steam) salinity at 654.5 mTVD

Hughmark parameter, $\eta$

Roughness factor, $\varepsilon$

Effective thermal conductivity, $\kappa$
$=52.4 \mathrm{~kg} / \mathrm{s}$

$=31.69 \mathrm{bars}$

$=1018 \mathrm{~kJ} / \mathrm{kg}$

$=0.0000 \mathrm{~kg} / \mathrm{kg}$

$=0.0000 \mathrm{~kg} / \mathrm{kg}$

$=0.50$ for depths $<250 \mathrm{~m}$

$=0.50+0.01($ depth -250$)$ for $250 \mathrm{~m}<$ depth $<300 \mathrm{~m}$

$=1.00$ for depths $>300 \mathrm{~m}$

$=0.40 \mathrm{~mm}$ for all depths

$=4 \mathrm{~W} / \mathrm{m}-{ }^{\circ} \mathrm{C}$

$$
=62.8 \mathrm{~kg} / \mathrm{s}
$$

$=28.06 \mathrm{bars}$

$=1018 \mathrm{~kJ} / \mathrm{kg}$

$=0.0000 \mathrm{~kg} / \mathrm{kg}$

$=0.0000 \mathrm{~kg} / \mathrm{kg}$

$=0.15$ for depths $<250 \mathrm{~m}$

$=0.15+0.017($ depth -250$)$ for $250 \mathrm{~m}<$ depth $<300 \mathrm{~m}$

$=1.00$ for depths $>300 \mathrm{~m}$ $0.40 \mathrm{~mm}$ for all depths

$=4 \mathrm{~W} / \mathrm{m}^{-}{ }^{\circ} \mathrm{C}$ 


\section{B.36 WELL GH-20}

Well Geometry:

\begin{tabular}{|c|c|c|c|}
\hline $\begin{array}{c}\text { Vertical } \\
\text { Depth } \\
\text { (meters) }\end{array}$ & $\begin{array}{c}\text { Measured } \\
\text { Depth } \\
\text { (meters) }\end{array}$ & $\begin{array}{c}\text { Angle with } \\
\text { Vertical } \\
\text { (Degrees) }\end{array}$ & $\begin{array}{c}\text { Internal } \\
\text { Diameter } \\
\text { (mm) }\end{array}$ \\
\hline 298.7 & 300.0 & 5.336 & 224 \\
785.8 & 850.0 & 27.670 & 224 \\
\hline
\end{tabular}

Stable Temperature Profile:

\begin{tabular}{|c|c|}
\hline $\begin{array}{c}\text { Vertical Depth } \\
\text { (meters) }\end{array}$ & $\begin{array}{c}\text { Temperature } \\
\text { (Degrees Celsius) }\end{array}$ \\
\hline 0 & 10 \\
400 & 175 \\
800 & 200 \\
\hline
\end{tabular}

\section{Other Model Input Parameters:}

\section{Discharge Test (April 24, 1991)}

Discharge rate

Pressure at $785.8 \mathrm{mTVD}$

Flowing enthalpy at $785.8 \mathrm{mTVD}$

Fluid (liquid + steam) gas content at 785.8 mTVD

Fluid (liquid + steam) salinity at $785.8 \mathrm{mTVD}$

Hughmark parameter, $\eta$

Roughness factor, $\varepsilon$

Effective thermal conductivity, $\kappa$

Discharge Test (April 25, 1991)

Discharge rate

Pressure at $785.8 \mathrm{mTVD}$

Flowing enthalpy at $785.8 \mathrm{mTVD}$

Fluid (liquid + steam) gas content at $785.8 \mathrm{mTVD}$

Fluid (liquid + steam) salinity at $785.8 \mathrm{mTVD}$

Hughmark parameter, $\eta$

Roughness factor, $\varepsilon$

Effective thermal conductivity, $\kappa$

Discharge Test (April 26, 1991)

Discharge rate

Pressure at $785.8 \mathrm{mTVD}$

Flowing enthalpy at $785.8 \mathrm{mTVD}$

Fluid (liquid + steam) gas content at 785.8 mTVD

Fluid (liquid + steam) salinity at $785.8 \mathrm{mTVD}$

Hughmark parameter, $\eta$

Roughness factor, $\varepsilon$

Effective thermal conductivity, $\kappa$
$=60.1 \mathrm{~kg} / \mathrm{s}$

$=47.43 \mathrm{bars}$

$=1042 \mathrm{~kJ} / \mathrm{kg}$

$=0.0000 \mathrm{~kg} / \mathrm{kg}$

$=0.0000 \mathrm{~kg} / \mathrm{kg}$

$=1.00$ for all depths

$=0.016 \mathrm{~mm}$ for all depths

$=4 \mathrm{~W} / \mathrm{m}-{ }^{\circ} \mathrm{C}$

$=69.9 \mathrm{~kg} / \mathrm{s}$

$=46.00 \mathrm{bars}$

$=1042 \mathrm{~kJ} / \mathrm{kg}$

$=0.0000 \mathrm{~kg} / \mathrm{kg}$

$=0.0000 \mathrm{~kg} / \mathrm{kg}$

$=1.00$ for all depths

$=0.016 \mathrm{~mm}$ for all depths

$=4 \mathrm{~W} / \mathrm{m}-{ }^{\circ} \mathrm{C}$

$=78.6 \mathrm{~kg} / \mathrm{s}$

$=44.95 \mathrm{bars}$

$=1042 \mathrm{~kJ} / \mathrm{kg}$

$=0.0000 \mathrm{~kg} / \mathrm{kg}$

$=0.0000 \mathrm{~kg} / \mathrm{kg}$

$=1.00$ for all depths

$=0.016 \mathrm{~mm}$ for all depths

$=4 \mathrm{~W} / \mathrm{m}-{ }^{\circ} \mathrm{C}$ 


\section{B.37 WELL S-2(I):}

\section{Well Geometry:}

\begin{tabular}{|c|c|c|c|}
\hline $\begin{array}{c}\text { Vertical } \\
\text { Depth } \\
\text { (meters) }\end{array}$ & $\begin{array}{c}\text { Measured } \\
\text { Depth } \\
\text { (meters) }\end{array}$ & $\begin{array}{c}\text { Angle with } \\
\text { Vertical } \\
\text { (Degrees) }\end{array}$ & $\begin{array}{c}\text { Internal } \\
\text { Diameter } \\
(\mathrm{mm})\end{array}$ \\
\hline 703.3 & 703.3 & 0.000 & 102 \\
\hline
\end{tabular}

\section{Stable Temperature Profile:}

\begin{tabular}{|c|c|}
\hline $\begin{array}{c}\text { Vertical Depth } \\
\text { (meters) }\end{array}$ & $\begin{array}{c}\text { Temperature } \\
\text { (Degrees Celsius) }\end{array}$ \\
\hline 0 & 20 \\
300 & 100 \\
400 & 175 \\
900 & 235 \\
\hline
\end{tabular}

\section{Other Model Input Parameters:}

Discharge rate

Pressure at $703.3 \mathrm{mTVD}$

Flowing enthalpy at $703.3 \mathrm{mTVD}$

Fluid (liquid + steam) gas content at 703.3 mTVD

Fluid (liquid + steam) salinity at $703.3 \mathrm{mTVD}$

Hughmark parameter, $\eta$

Roughness factor, $\varepsilon$

Effective thermal conductivity, $\kappa$
$=1.10 \mathrm{~kg} / \mathrm{s}$

$=6.73 \mathrm{bars}$

$=2340 \mathrm{~kJ} / \mathrm{kg}$

$=0.0000 \mathrm{~kg} / \mathrm{kg}$

$=0.0000 \mathrm{~kg} / \mathrm{kg}$

$=0.30$ for depths $<250 \mathrm{~m}$

$=0.30+0.014($ depth -250$)$ for $250 \mathrm{~m}<$ depth $<300 \mathrm{~m}$

$=1.00$ for depths $>300 \mathrm{~m}$

$=0.103 \mathrm{~mm}$ for all depths

$=4 \mathrm{~W} / \mathrm{m}-{ }^{\circ} \mathrm{C}$ 


\section{APPENDIX C: NUMERICAL SIMULATIONS}

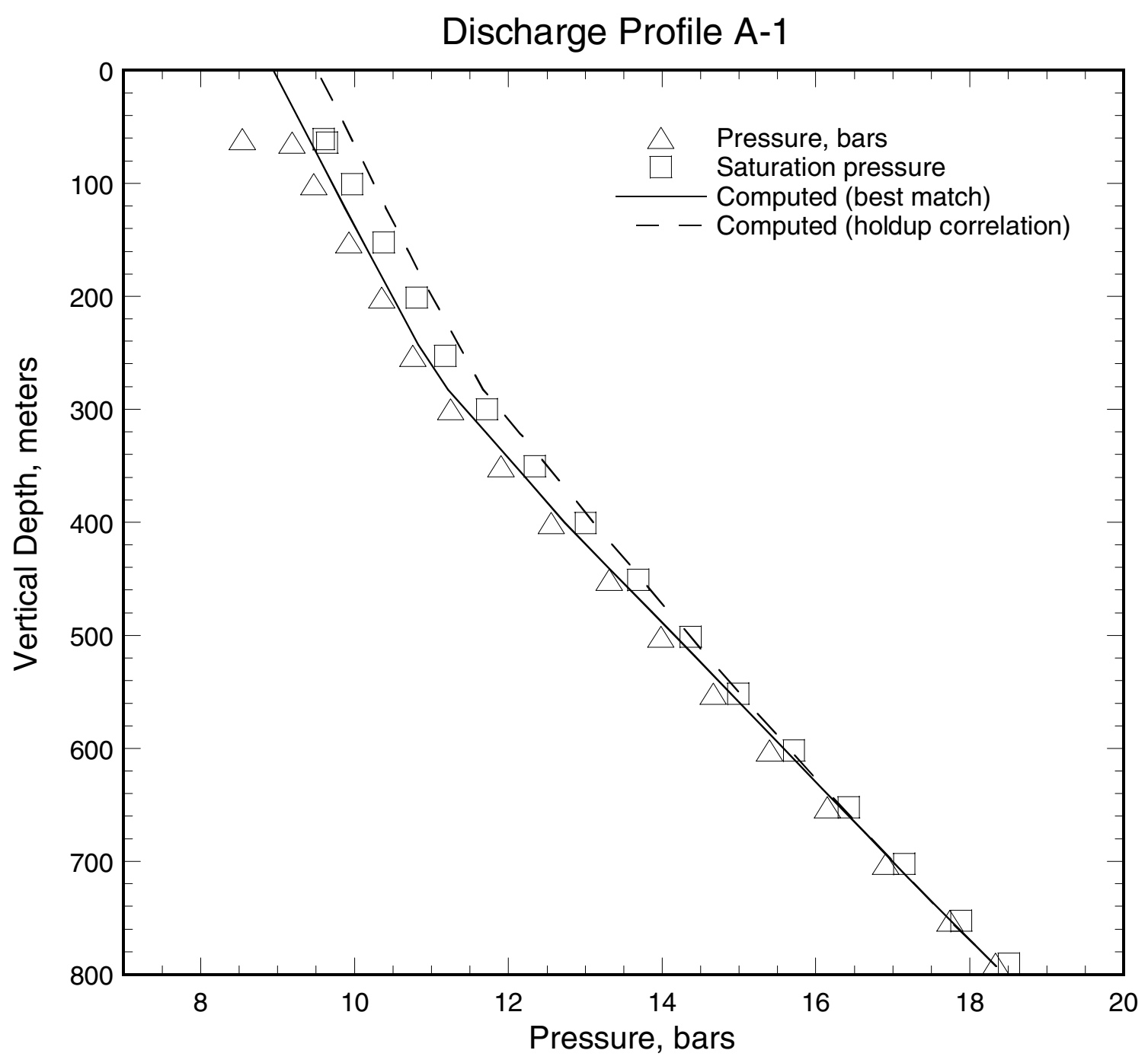

Figure C.1. Pressure profile (triangles) recorded in discharging well A-1. The squares indicate saturation pressure corresponding to the local measured temperature. The solid line is the computed pressure profile using an adjustable holdup correlation (see Section 2 for details). The computed pressure profile using the correlation(s) for $K(Z)$ developed in Section 3 is shown as a dashed line. 


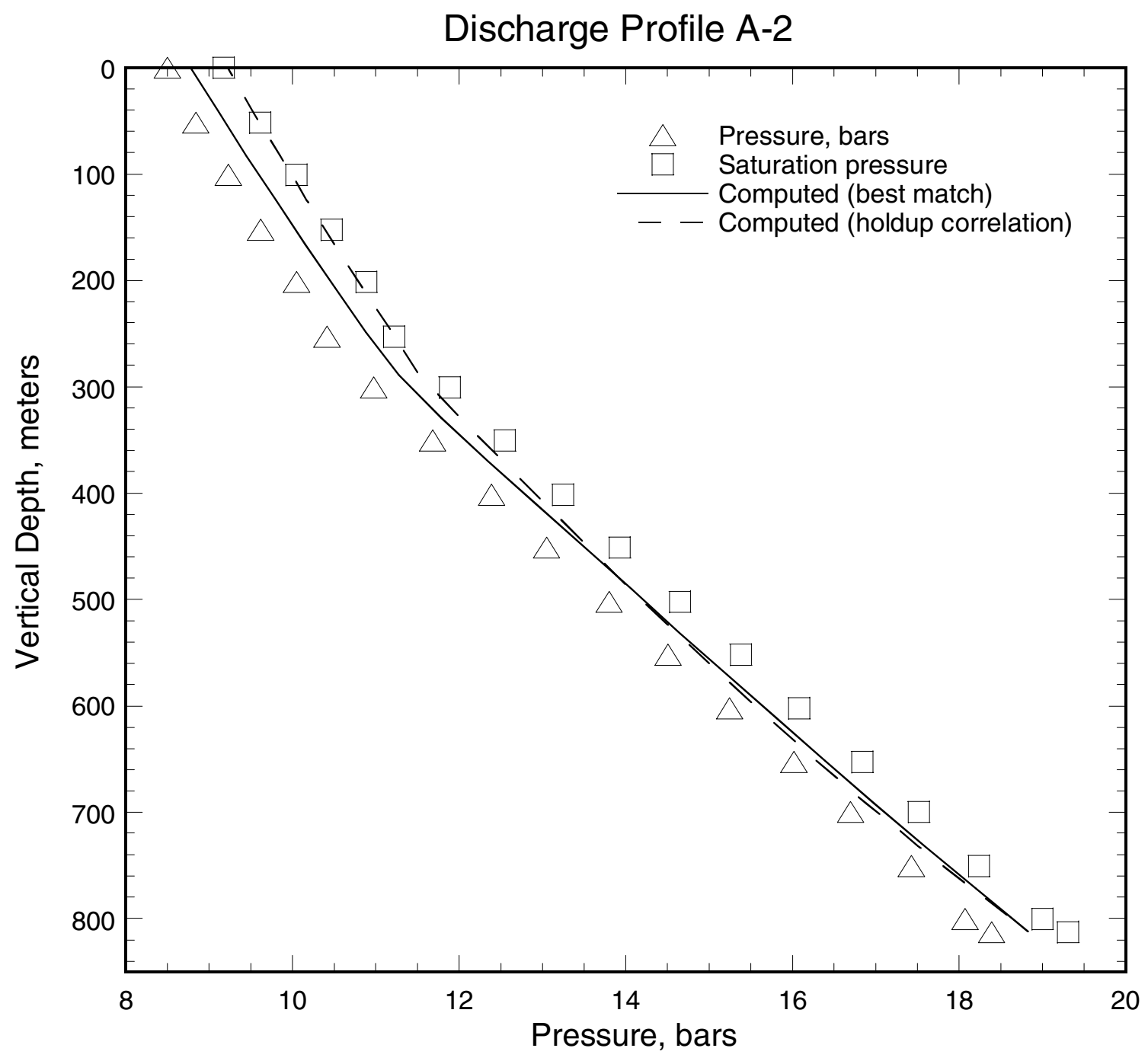

Figure C.2. Pressure profile (triangles) recorded in discharging well A-2. The squares indicate saturation pressure corresponding to the local measured temperature. The solid line is the computed pressure profile using an adjustable holdup correlation (see Section 2 for details). The computed pressure profile using the correlation(s) for $K(Z)$ developed in Section 3 is shown as a dashed line. 


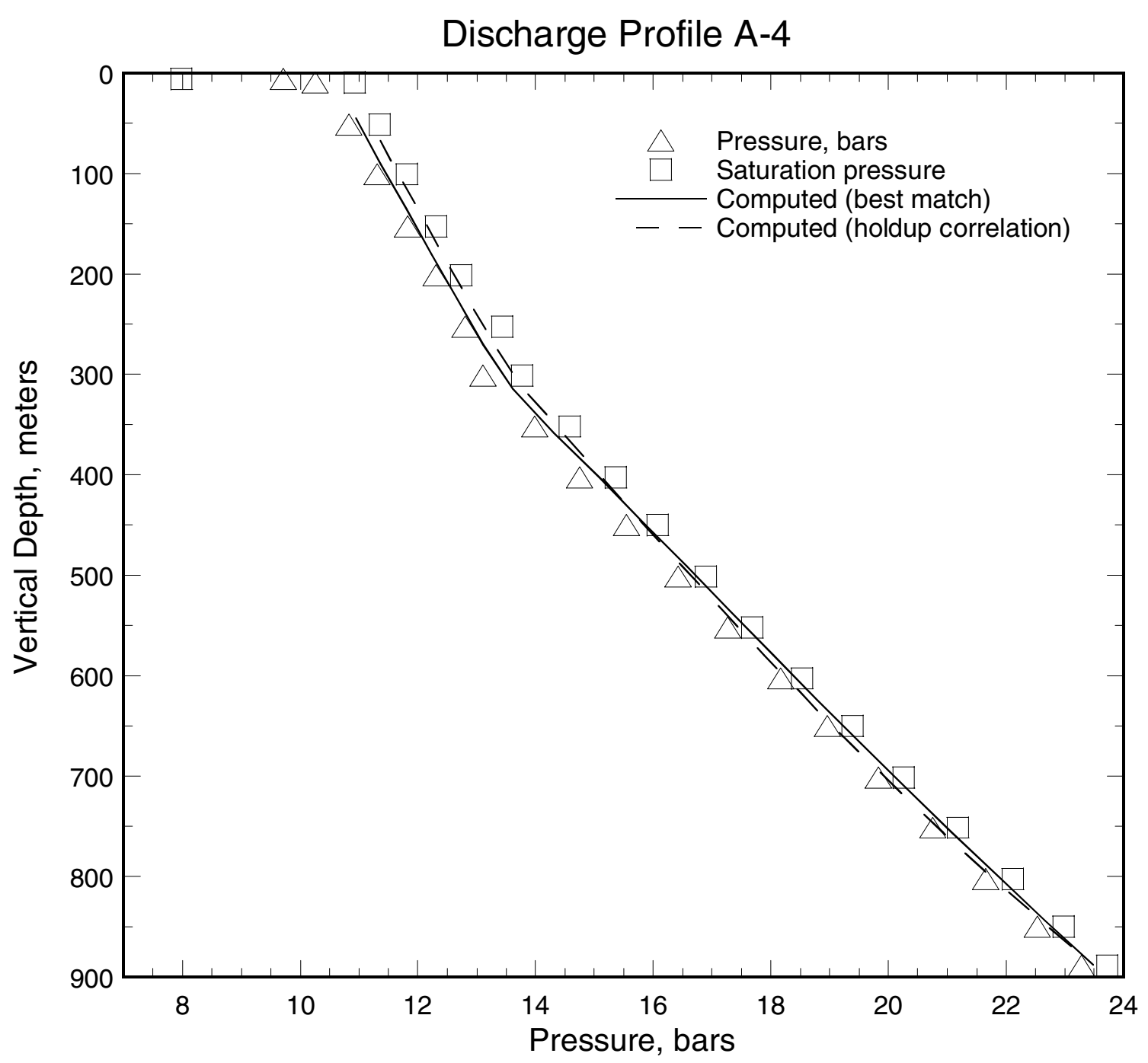

Figure C.3. Pressure profile (triangles) recorded in discharging well A-4. The squares indicate saturation pressure corresponding to the local measured temperature. The solid line is the computed pressure profile using an adjustable holdup correlation (see Section 2 for details). The computed pressure profile using the correlation(s) for $K(Z)$ developed in Section 3 is shown as a dashed line. 


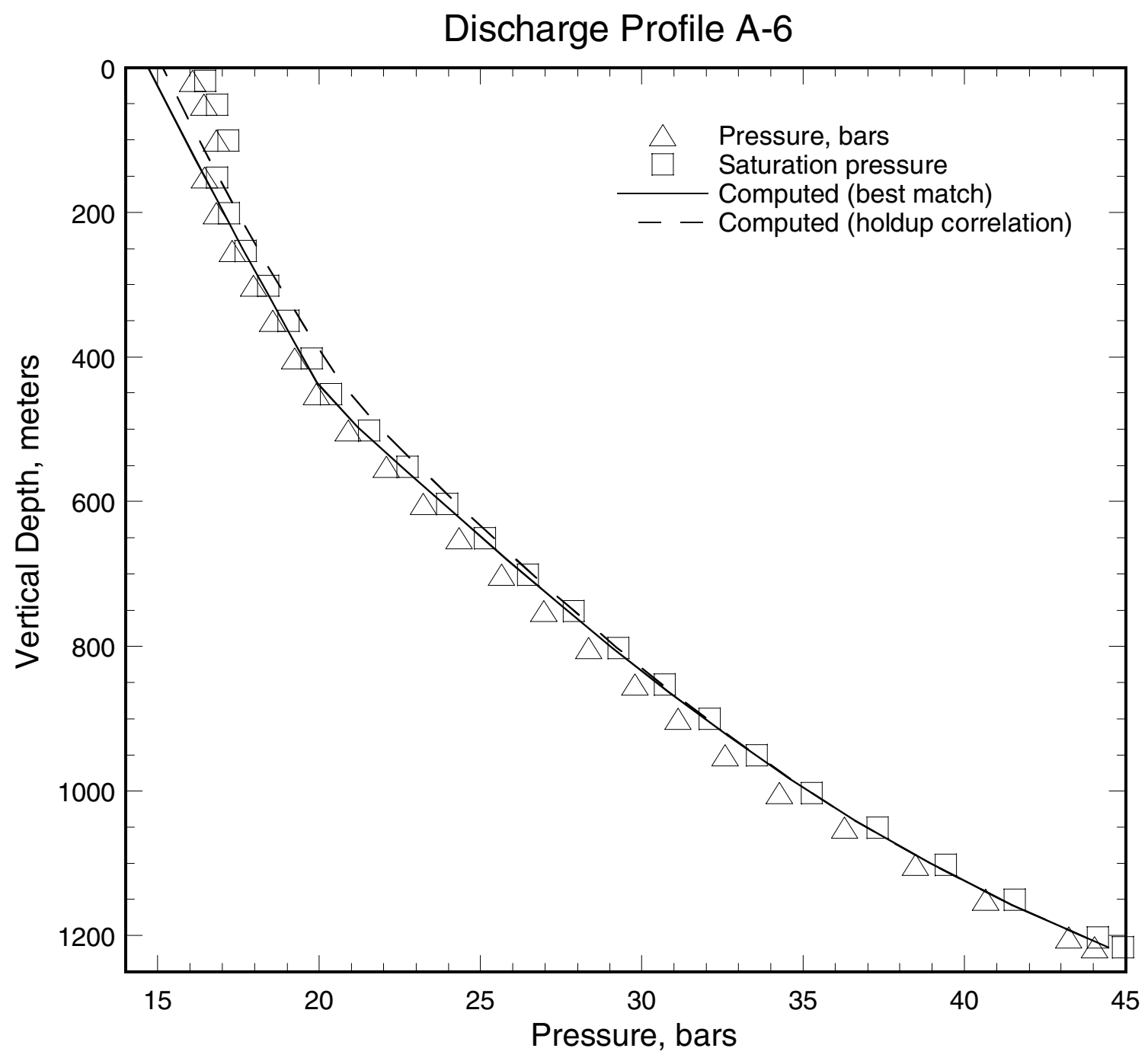

Figure C.4. Pressure profile (triangles) recorded in discharging well A-6. The squares indicate saturation pressure corresponding to the local measured temperature. The solid line is the computed pressure profile using an adjustable holdup correlation (see Section 2 for details). The computed pressure profile using the correlation(s) for $K(Z)$ developed in Section 3 is shown as a dashed line. 


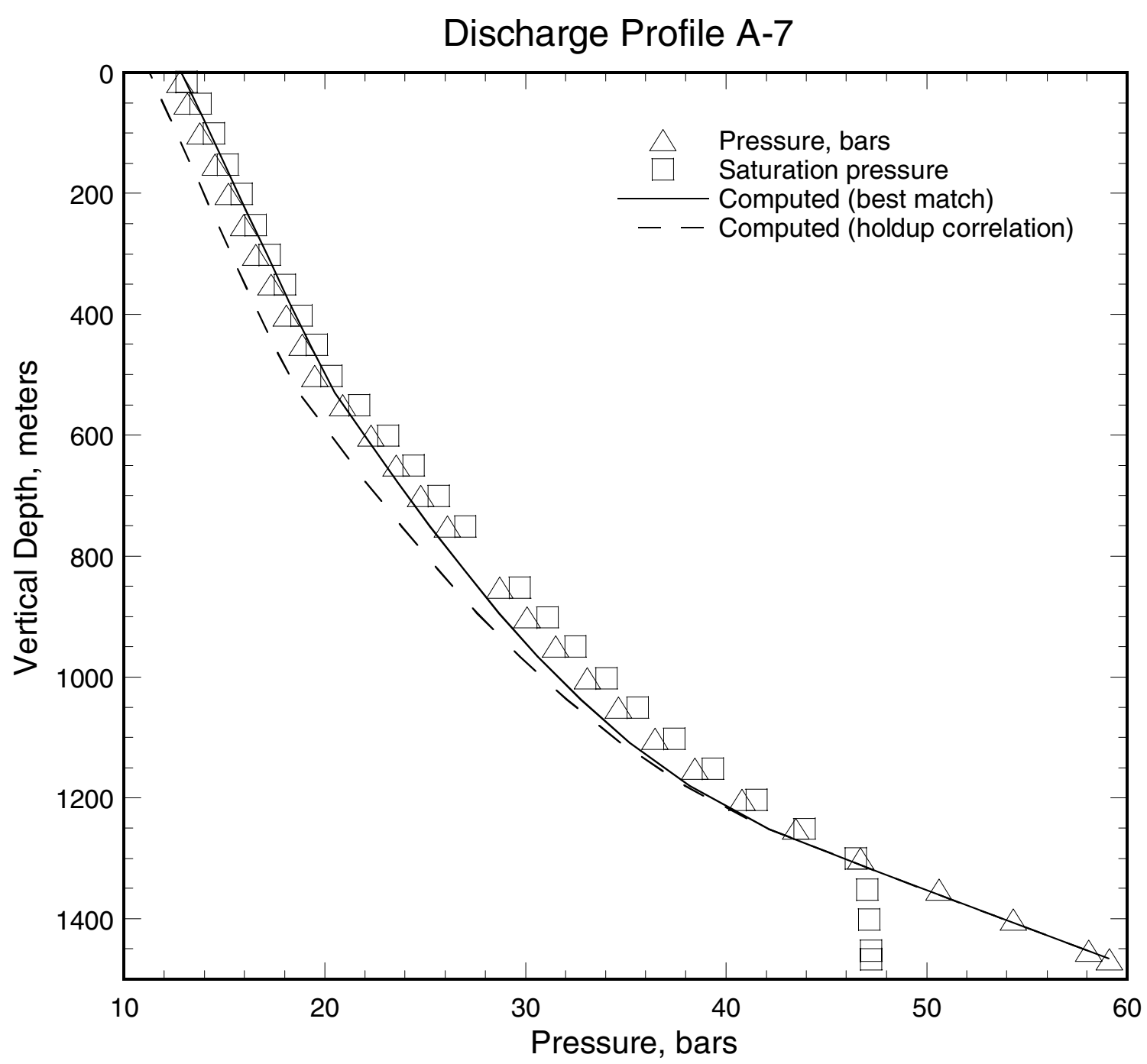

Figure C.5. Pressure profile (triangles) recorded in discharging well A-7. The squares indicate saturation pressure corresponding to the local measured temperature. The solid line is the computed pressure profile using an adjustable holdup correlation (see Section 2 for details). The computed pressure profile using the correlation(s) for $K(Z)$ developed in Section 3 is shown as a dashed line. 


\section{Discharge Profile A-8}

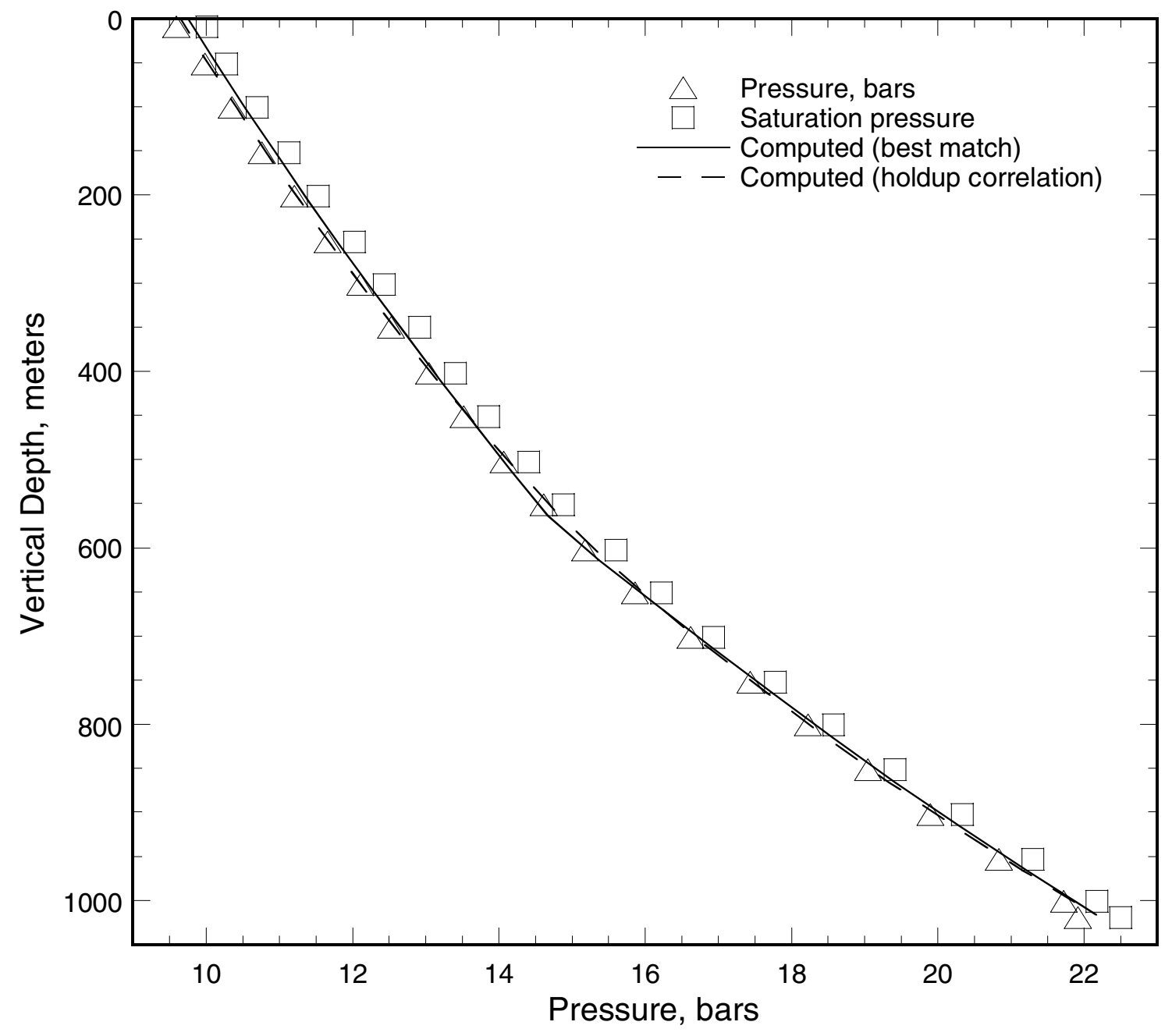

Figure C.6. Pressure profile (triangles) recorded in discharging well A-8. The squares indicate saturation pressure corresponding to the local measured temperature. The solid line is the computed pressure profile using an adjustable holdup correlation (see Section 2 for details). The computed pressure profile using the correlation(s) for $K(Z)$ developed in Section 3 is shown as a dashed line. 


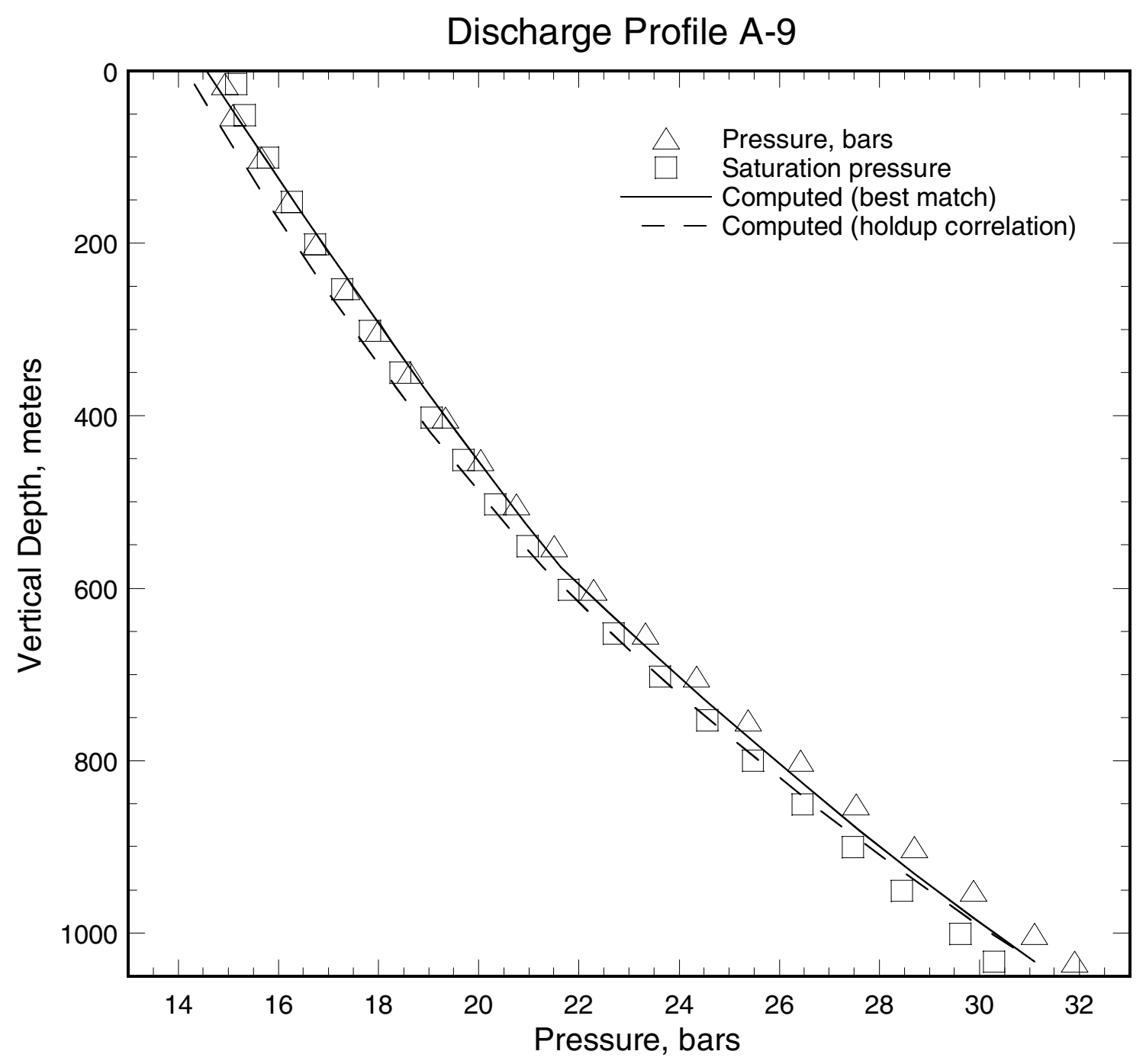

Figure C.7. Pressure profile (triangles) recorded in discharging well A-9. The squares indicate saturation pressure corresponding to the local measured temperature. The solid line is the computed pressure profile using an adjustable holdup correlation (see Section 2 for details). The computed pressure profile using the correlation(s) for $K(Z)$ developed in Section 3 is shown as a dashed line. 


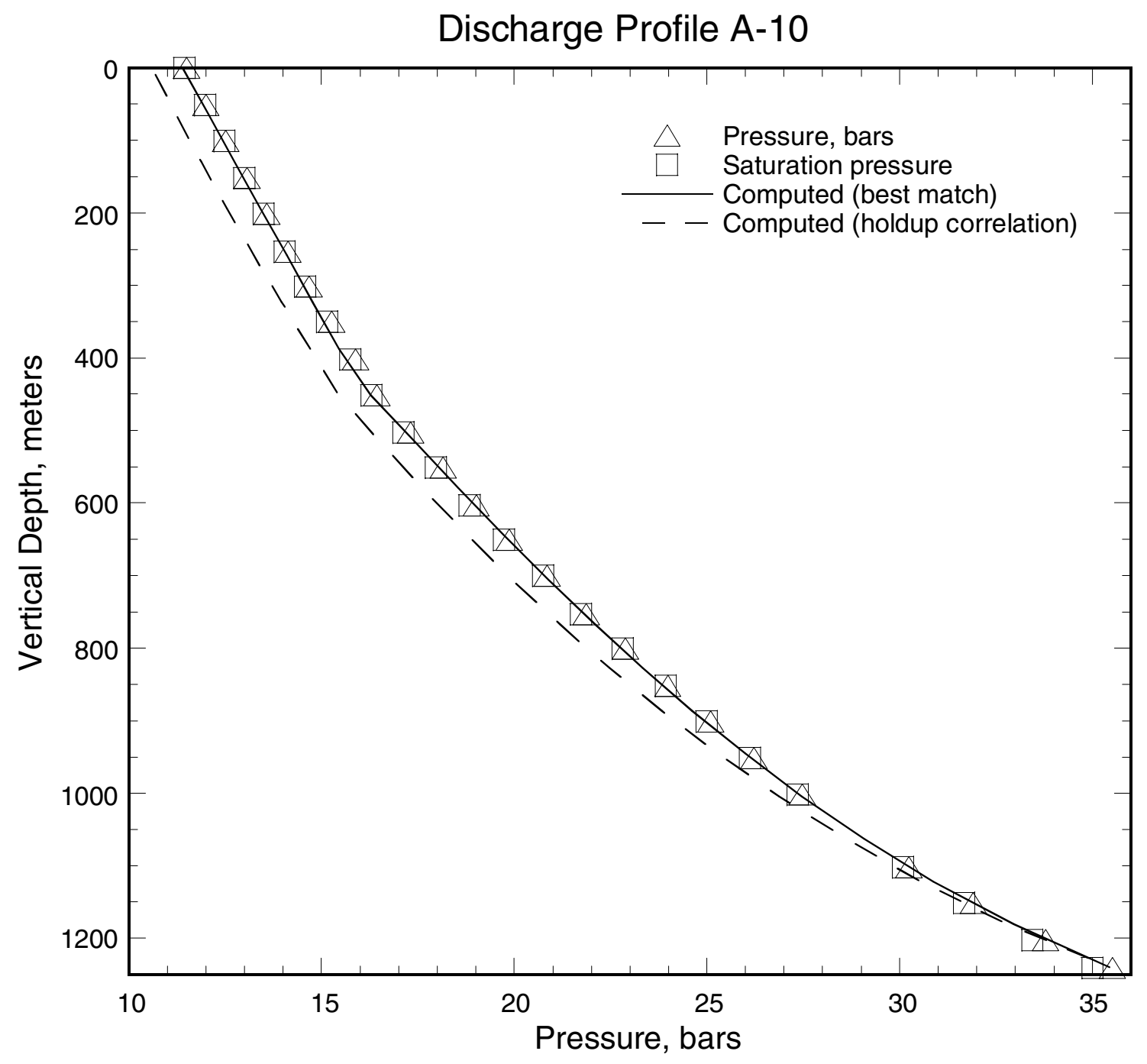

Figure C.8. Pressure profile (triangles) recorded in discharging well A-10. The squares indicate saturation pressure corresponding to the local measured temperature. The solid line is the computed pressure profile using an adjustable holdup correlation (see Section 2 for details). The computed pressure profile using the correlation(s) for $K(Z)$ developed in Section 3 is shown as a dashed line. 


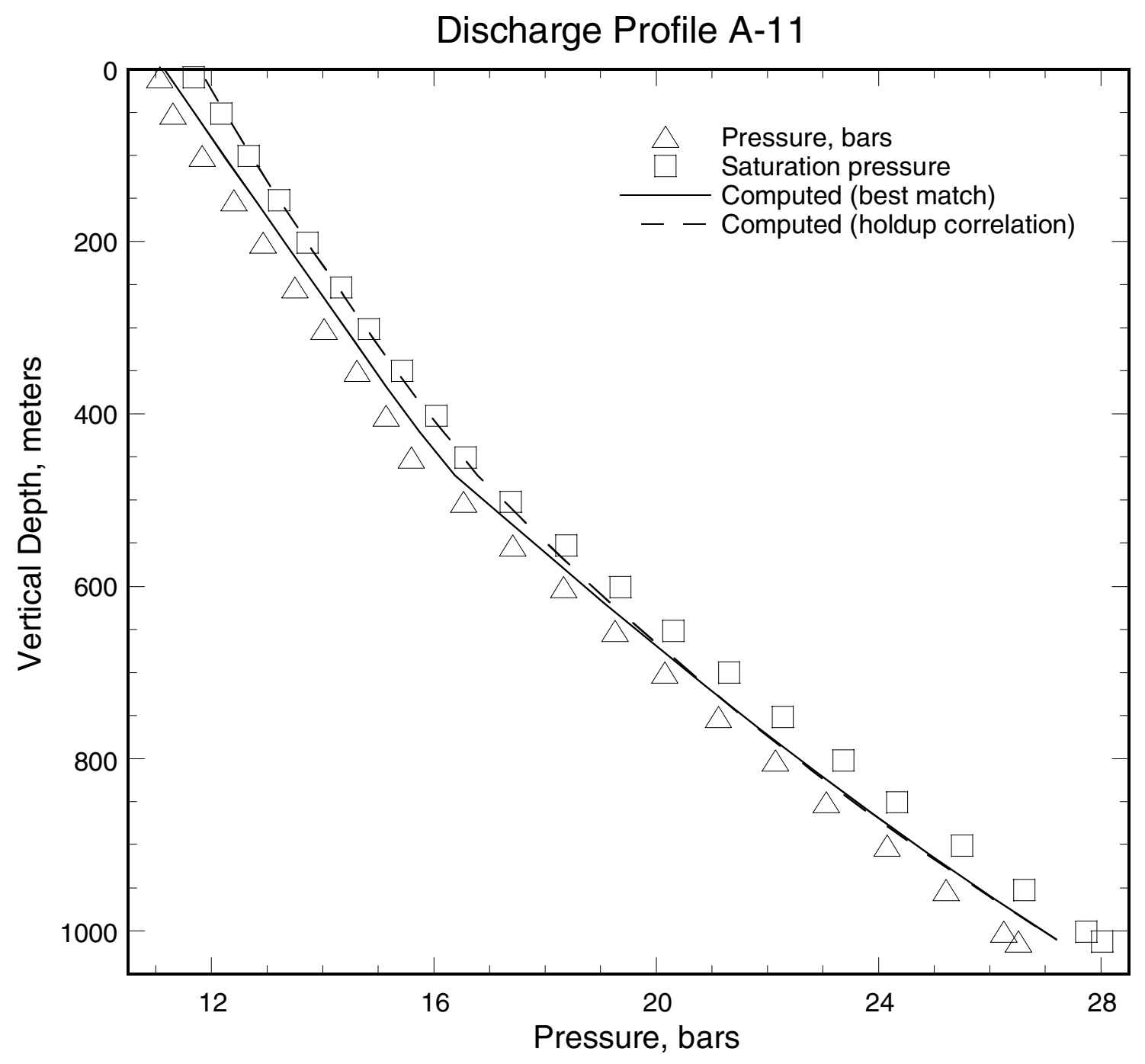

Figure C.9. Pressure profile (triangles) recorded in discharging well A-11. The squares indicate saturation pressure corresponding to the local measured temperature. The solid line is the computed pressure profile using an adjustable holdup correlation (see Section 2 for details). The computed pressure profile using the correlation(s) for $K(Z)$ developed in Section 3 is shown as a dashed line. 
Discharge Profile A-12

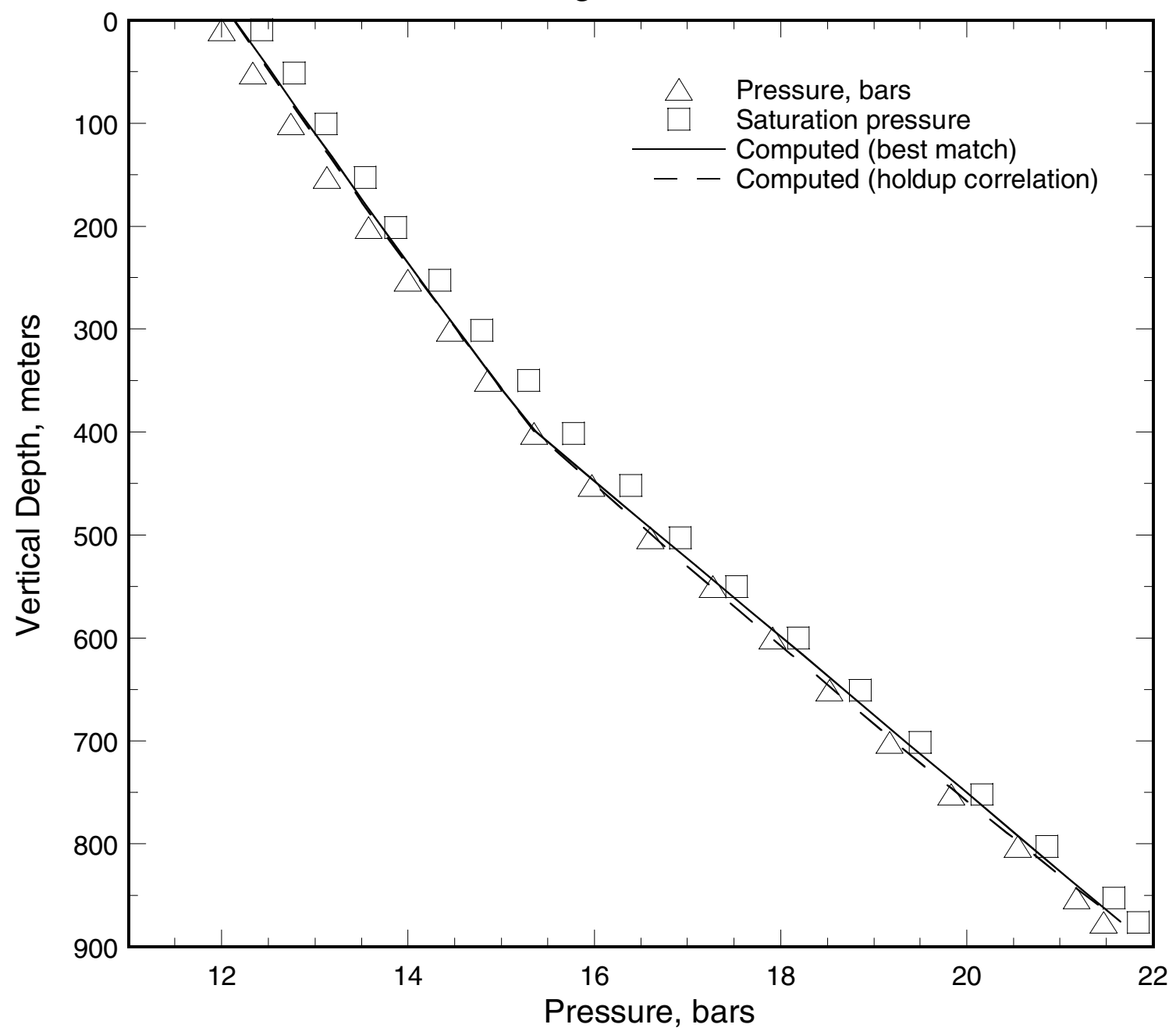

Figure C.10. Pressure profile (triangles) recorded in discharging well A-12. The squares indicate saturation pressure corresponding to the local measured temperature. The solid line is the computed pressure profile using an adjustable holdup correlation (see Section 2 for details). The computed pressure profile using the correlation(s) for $K(Z)$ developed in Section 3 is shown as a dashed line. 


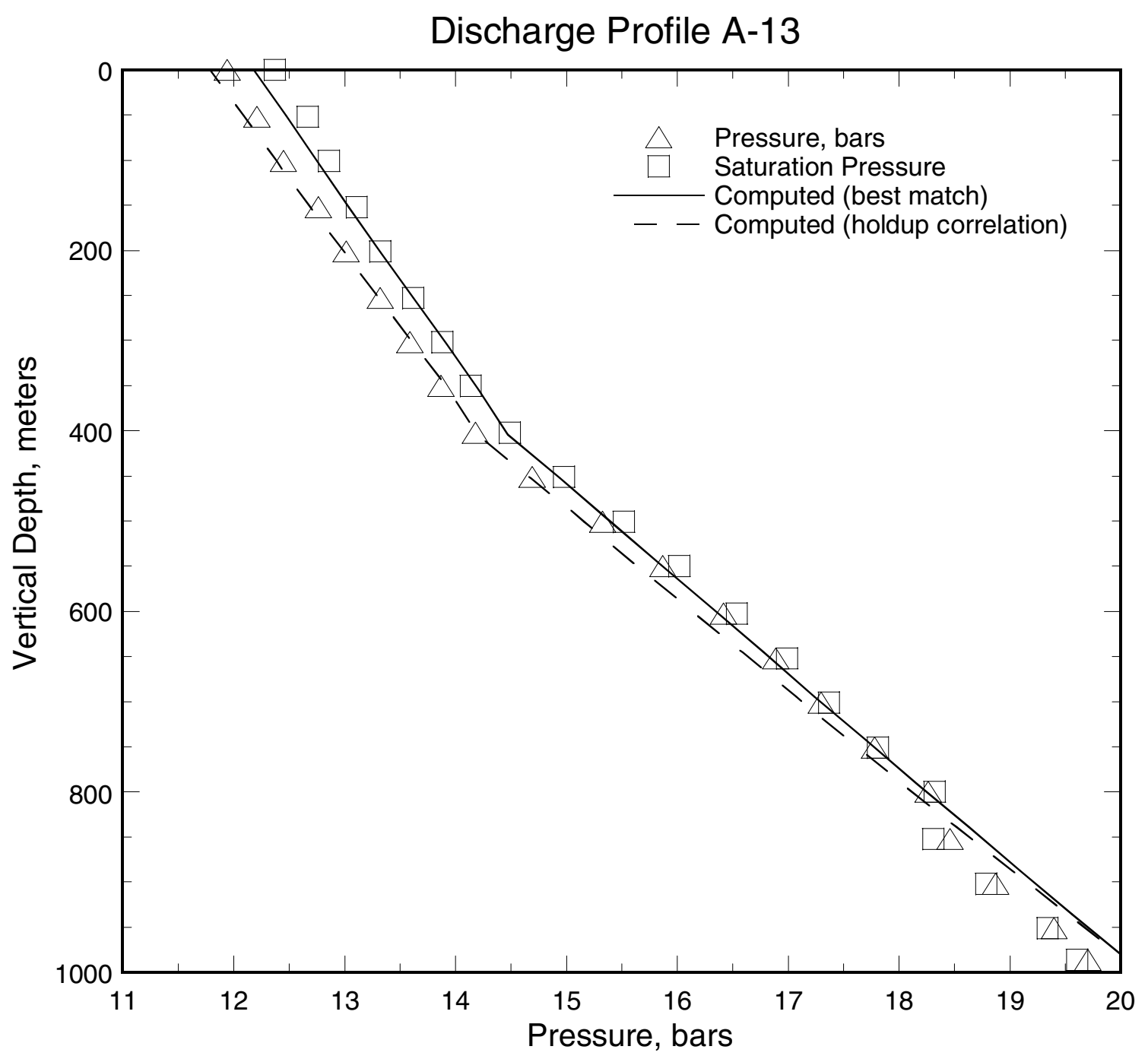

Figure C.11. Pressure profile (triangles) recorded in discharging well A-13. The squares indicate saturation pressure corresponding to the local measured temperature. The solid line is the computed pressure profile using an adjustable holdup correlation (see Section 2 for details). The computed pressure profile using the correlation(s) for $K(Z)$ developed in Section 3 is shown as a dashed line. 
Discharge Profile A-14

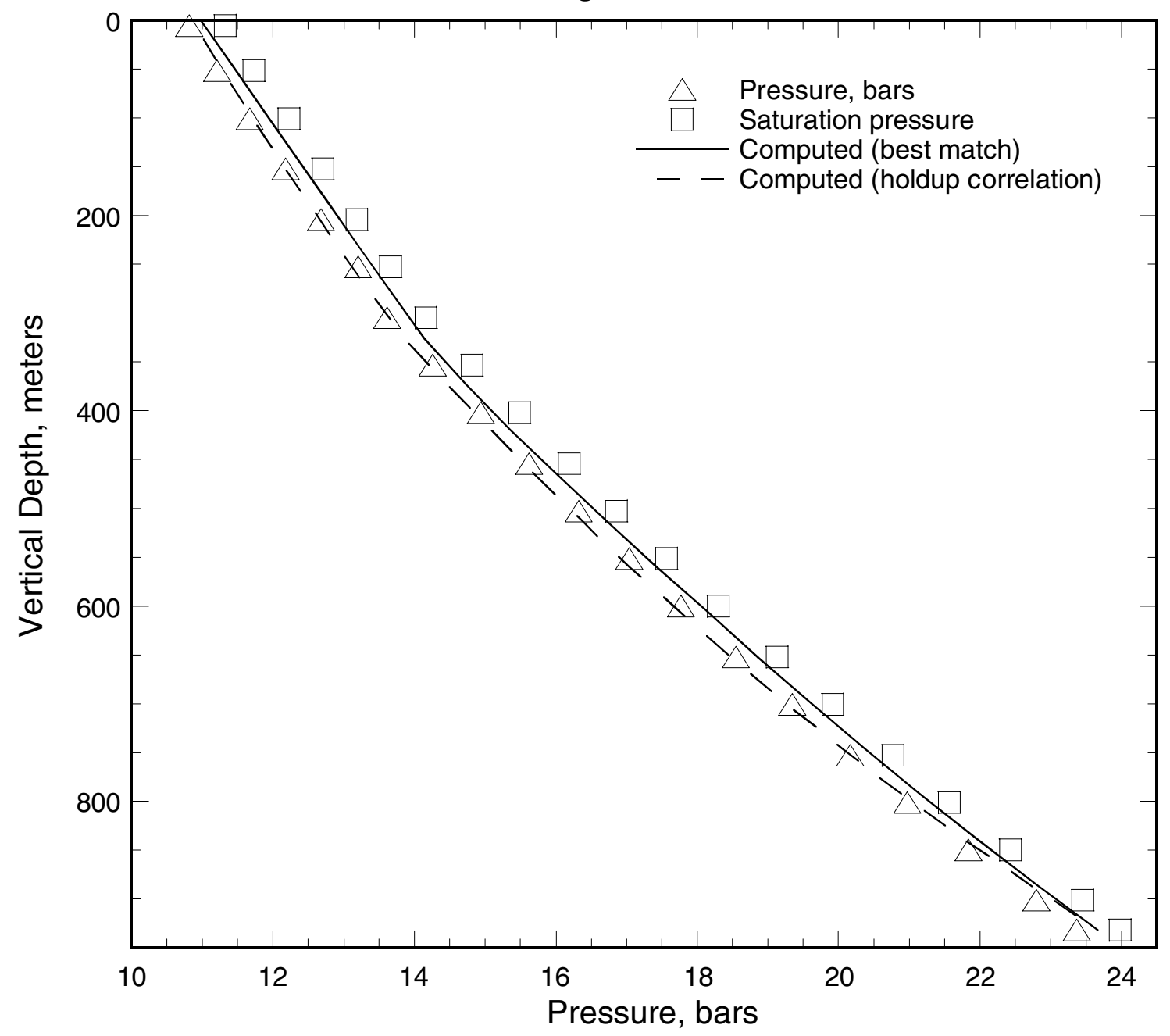

Figure C.12. Pressure profile (triangles) recorded in discharging well A-14. The squares indicate saturation pressure corresponding to the local measured temperature. The solid line is the computed pressure profile using an adjustable holdup correlation (see Section 2 for details). The computed pressure profile using the correlation(s) for $K(Z)$ developed in Section 3 is shown as a dashed line. 


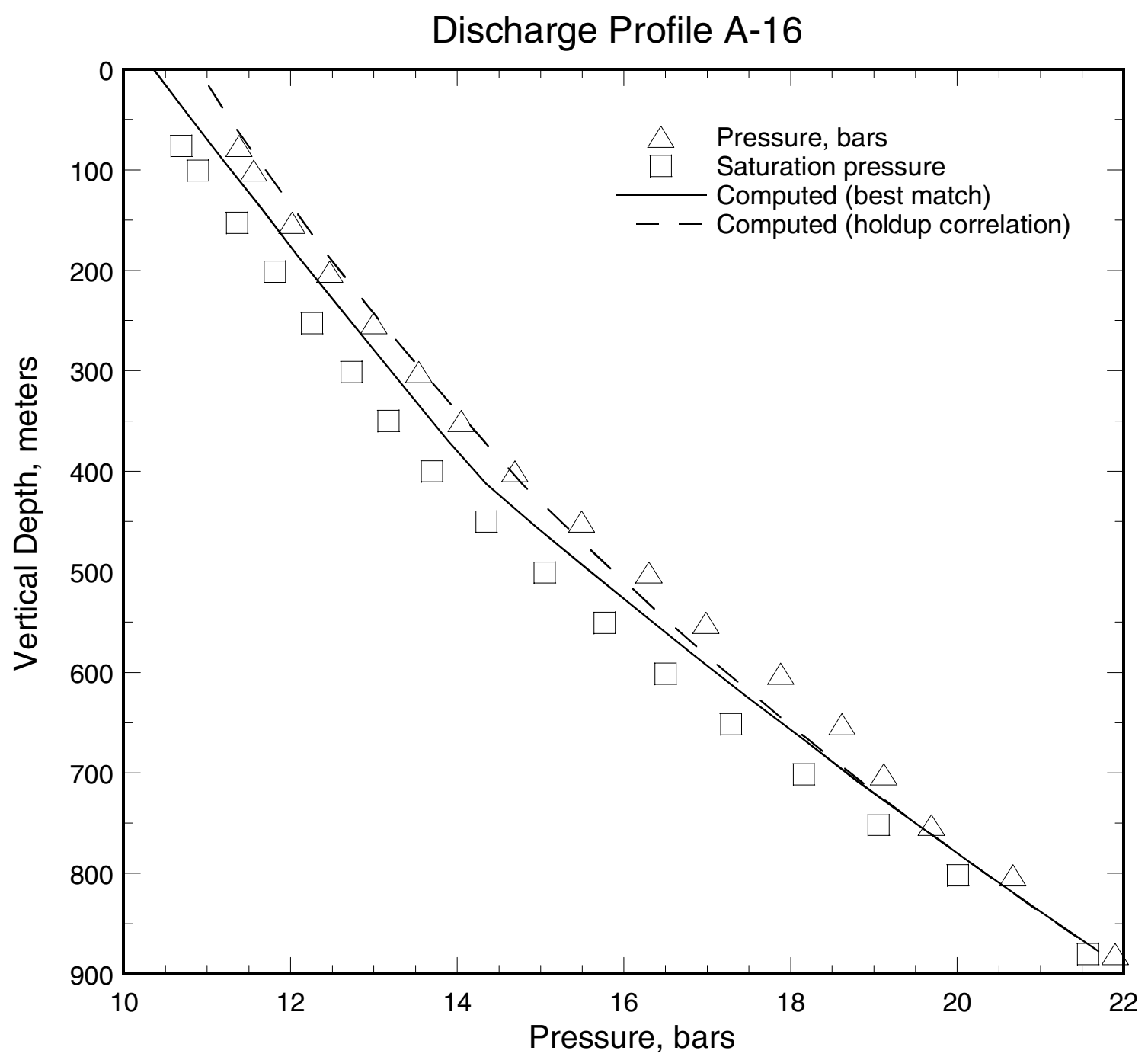

Figure C.13. Pressure profile (triangles) recorded in discharging well A-16. The squares indicate saturation pressure corresponding to the local measured temperature. The solid line is the computed pressure profile using an adjustable holdup correlation (see Section 2 for details). The computed pressure profile using the correlation(s) for $K(Z)$ developed in Section 3 is shown as a dashed line. 
Discharge Profile A-18

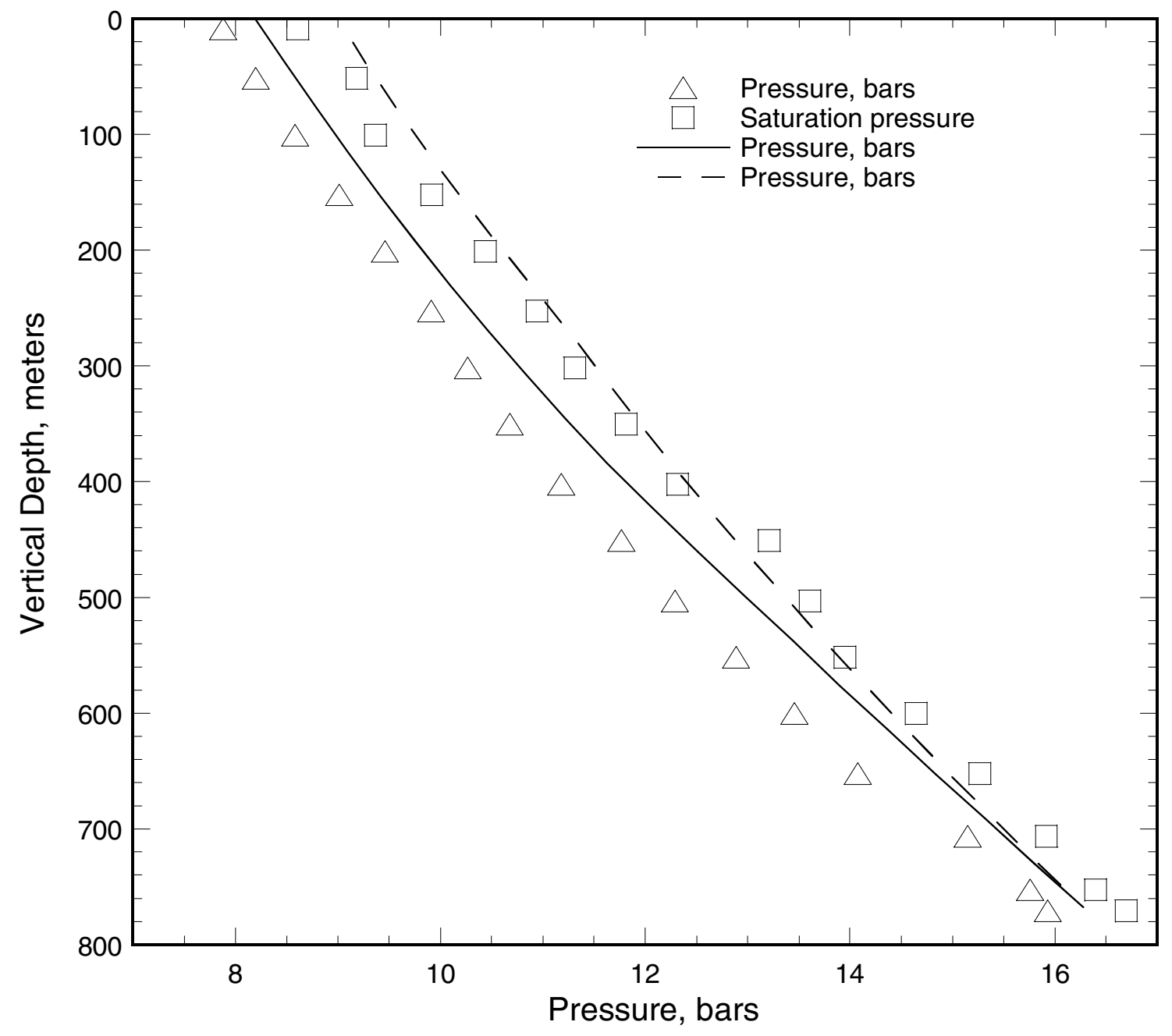

Figure C.14. Pressure profile (triangles) recorded in discharging well A-18. The squares indicate saturation pressure corresponding to the local measured temperature. The solid line is the computed pressure profile using an adjustable holdup correlation (see Section 2 for details). The computed pressure profile using the correlation(s) for $K(Z)$ developed in Section 3 is shown as a dashed line. 


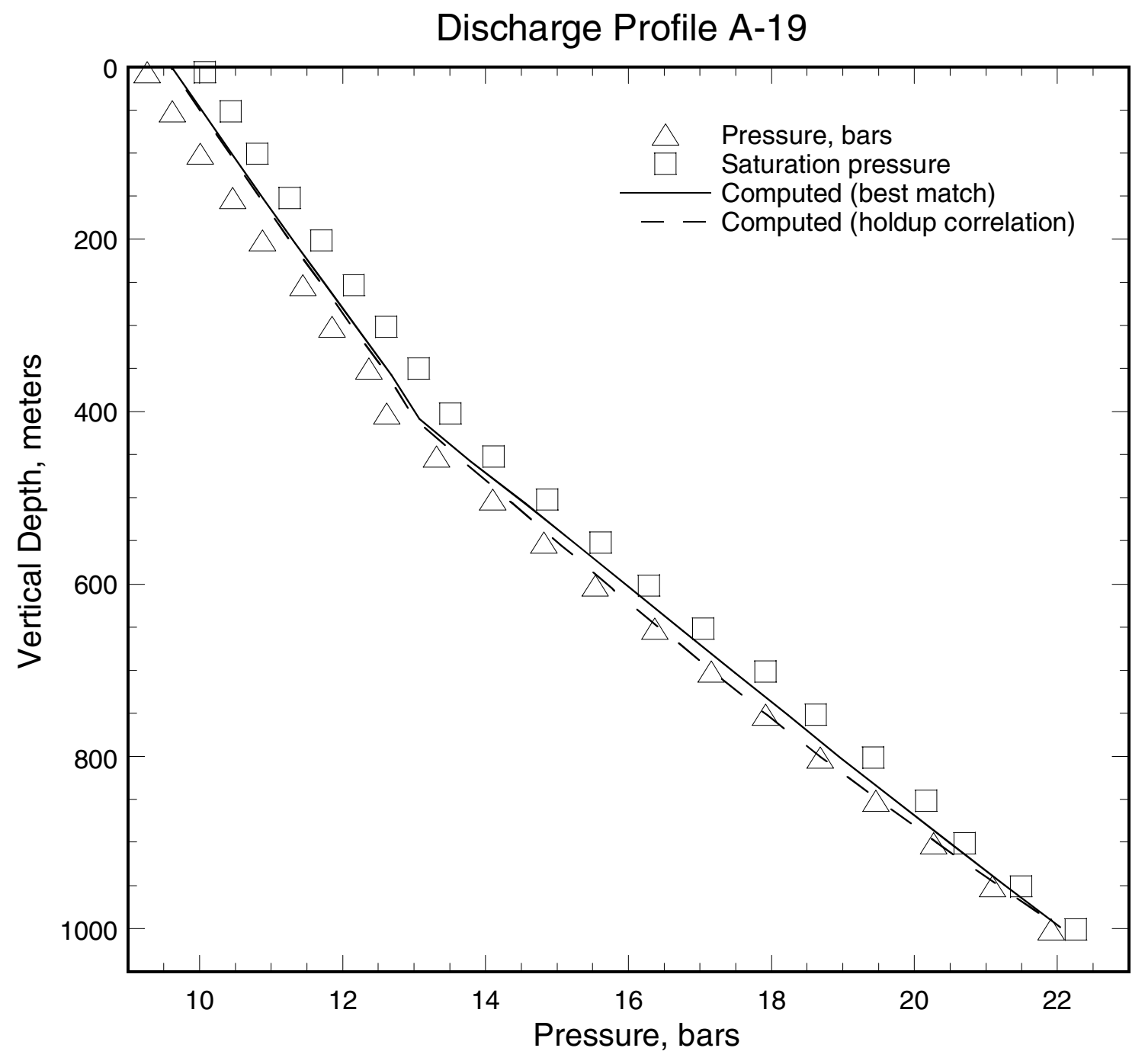

Figure C.15. Pressure profile (triangles) recorded in discharging well A-19. The squares indicate saturation pressure corresponding to the local measured temperature. The solid line is the computed pressure profile using an adjustable holdup correlation (see Section 2 for details). The computed pressure profile using the correlation(s) for $K(Z)$ developed in Section 3 is shown as a dashed line. 
Discharge Profile A-20

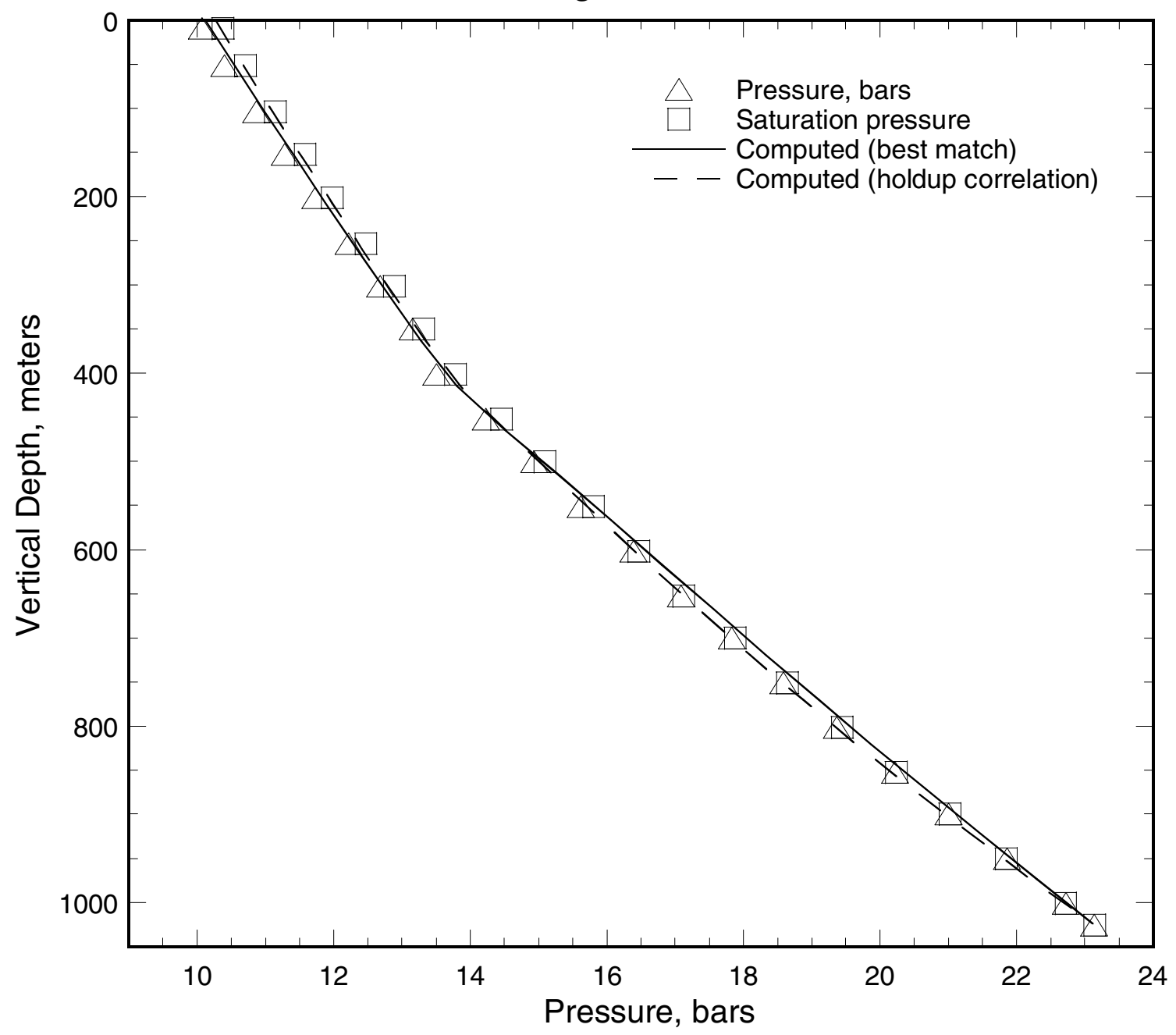

Figure C.16. Pressure profile (triangles) recorded in discharging well A-20. The squares indicate saturation pressure corresponding to the local measured temperature. The solid line is the computed pressure profile using an adjustable holdup correlation (see Section 2 for details). The computed pressure profile using the correlation(s) for $K(Z)$ developed in Section 3 is shown as a dashed line. 


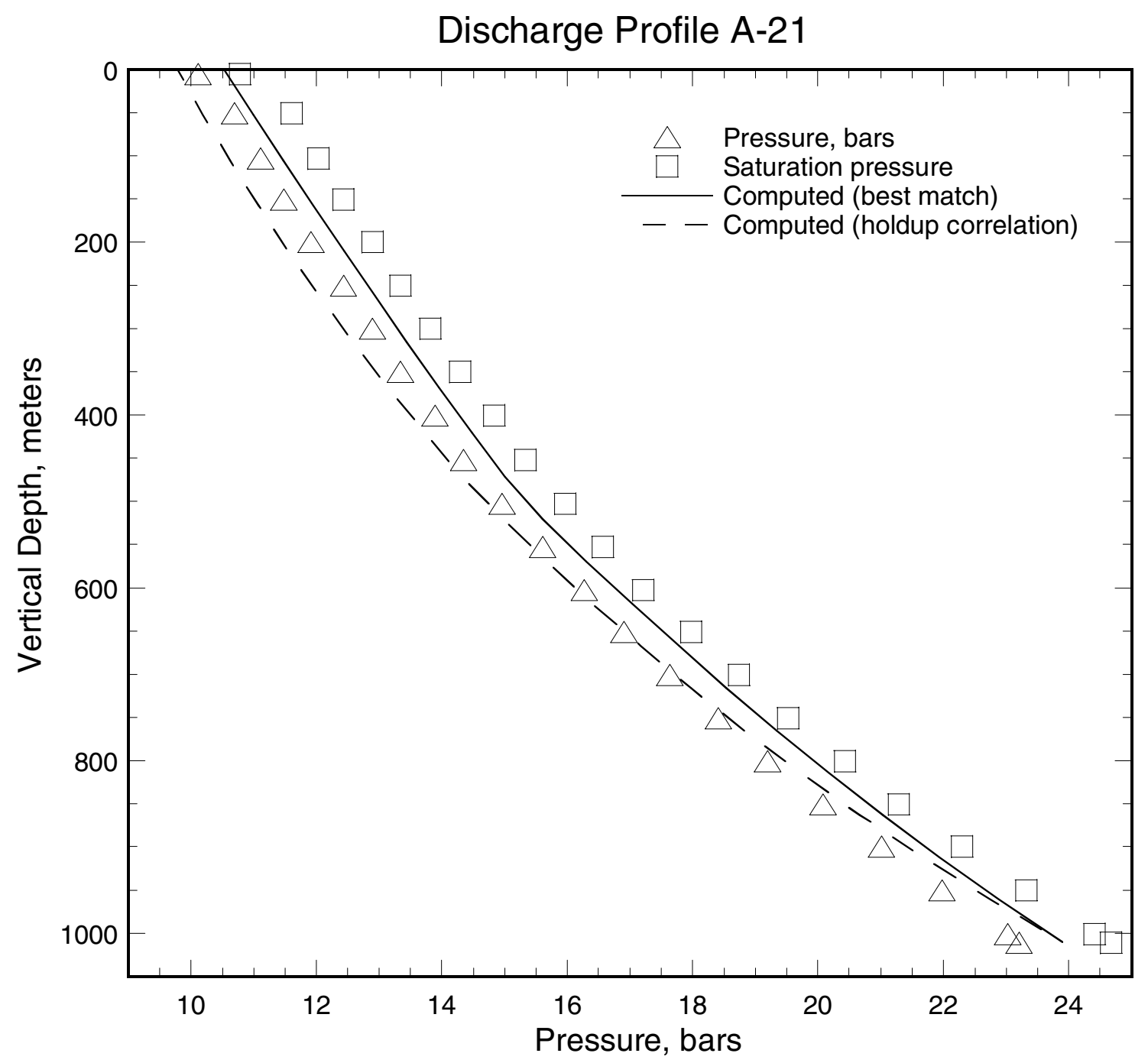

Figure C.17. Pressure profile (triangles) recorded in discharging well A-21. The squares indicate saturation pressure corresponding to the local measured temperature. The solid line is the computed pressure profile using an adjustable holdup correlation (see Section 2 for details). The computed pressure profile using the correlation(s) for $K(Z)$ developed in Section 3 is shown as a dashed line. 


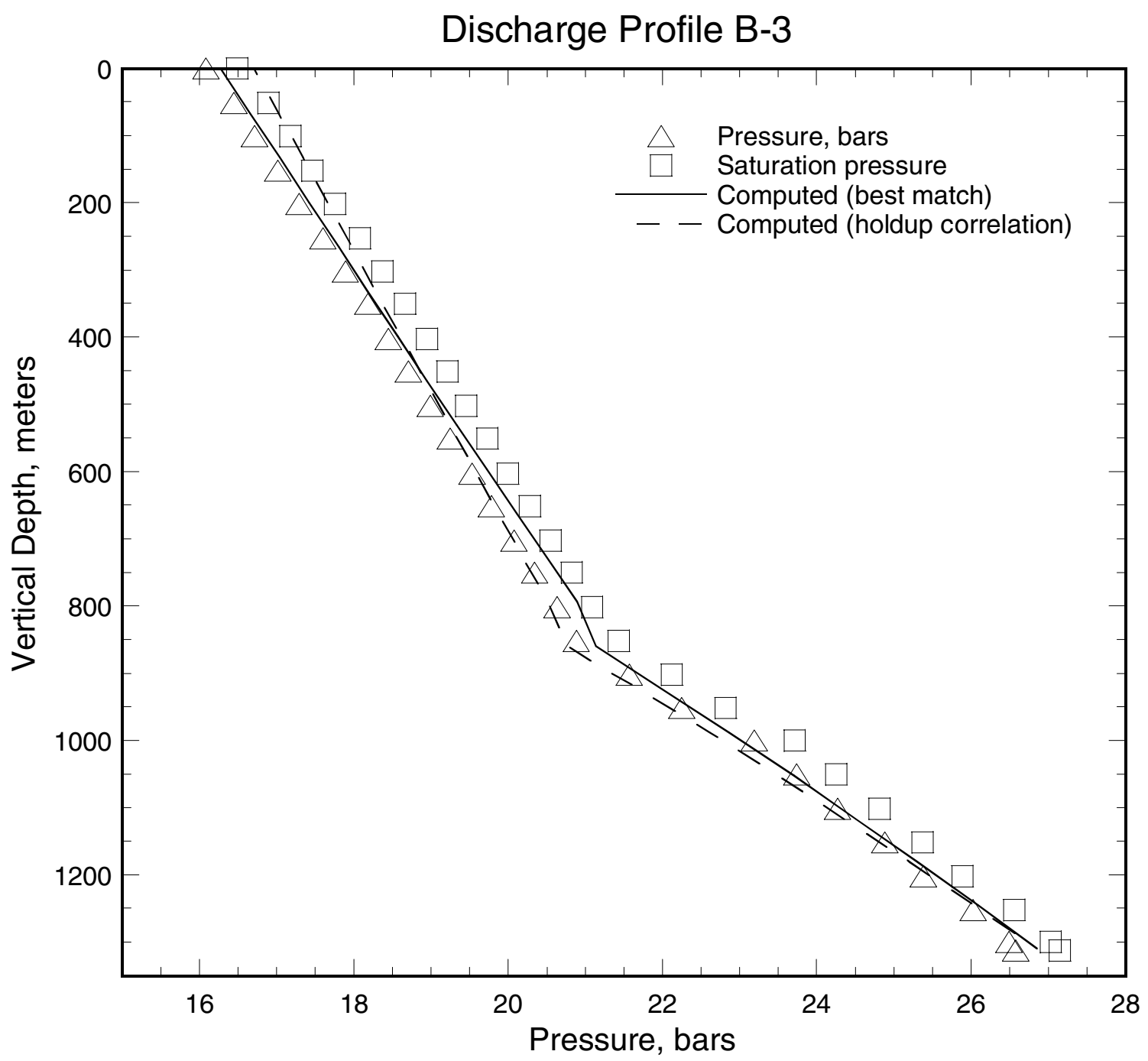

Figure C.18. Pressure profile (triangles) recorded in discharging well B-3. The squares indicate saturation pressure corresponding to the local measured temperature. The solid line is the computed pressure profile using an adjustable holdup correlation (see Section 2 for details). The computed pressure profile using the correlation(s) for $K(Z)$ developed in Section 3 is shown as a dashed line. 


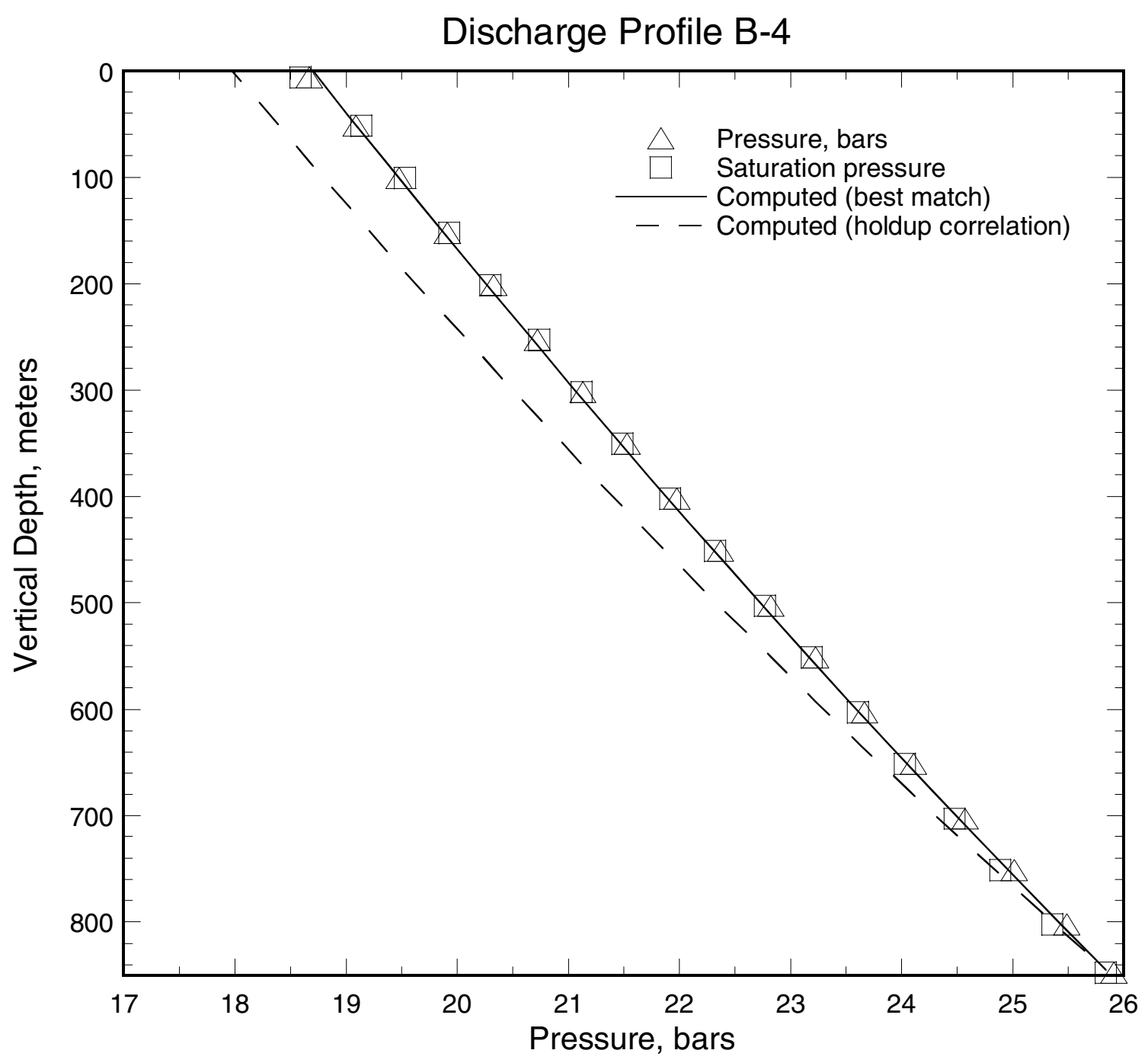

Figure C.19. Pressure profile (triangles) recorded in discharging well B-4. The squares indicate saturation pressure corresponding to the local measured temperature. The solid line is the computed pressure profile using an adjustable holdup correlation (see Section 2 for details). The computed pressure profile using the correlation(s) for $K(Z)$ developed in Section 3 is shown as a dashed line. 


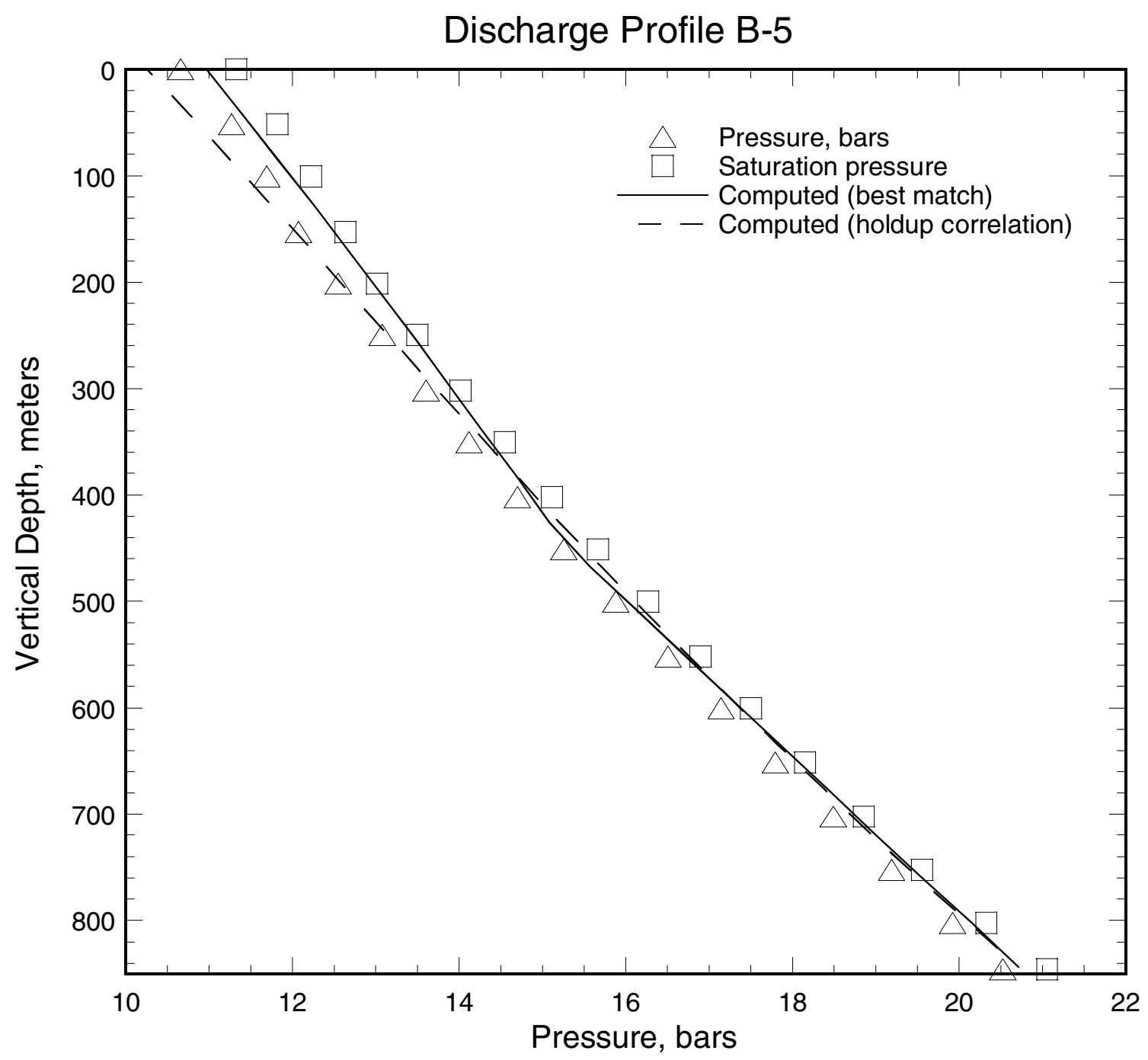

Figure C.20. Pressure profile (triangles) recorded in discharging well B-5. The squares indicate saturation pressure corresponding to the local measured temperature. The solid line is the computed pressure profile using an adjustable holdup correlation (see Section 2 for details). The computed pressure profile using the correlation(s) for $K(Z)$ developed in Section 3 is shown as a dashed line. 


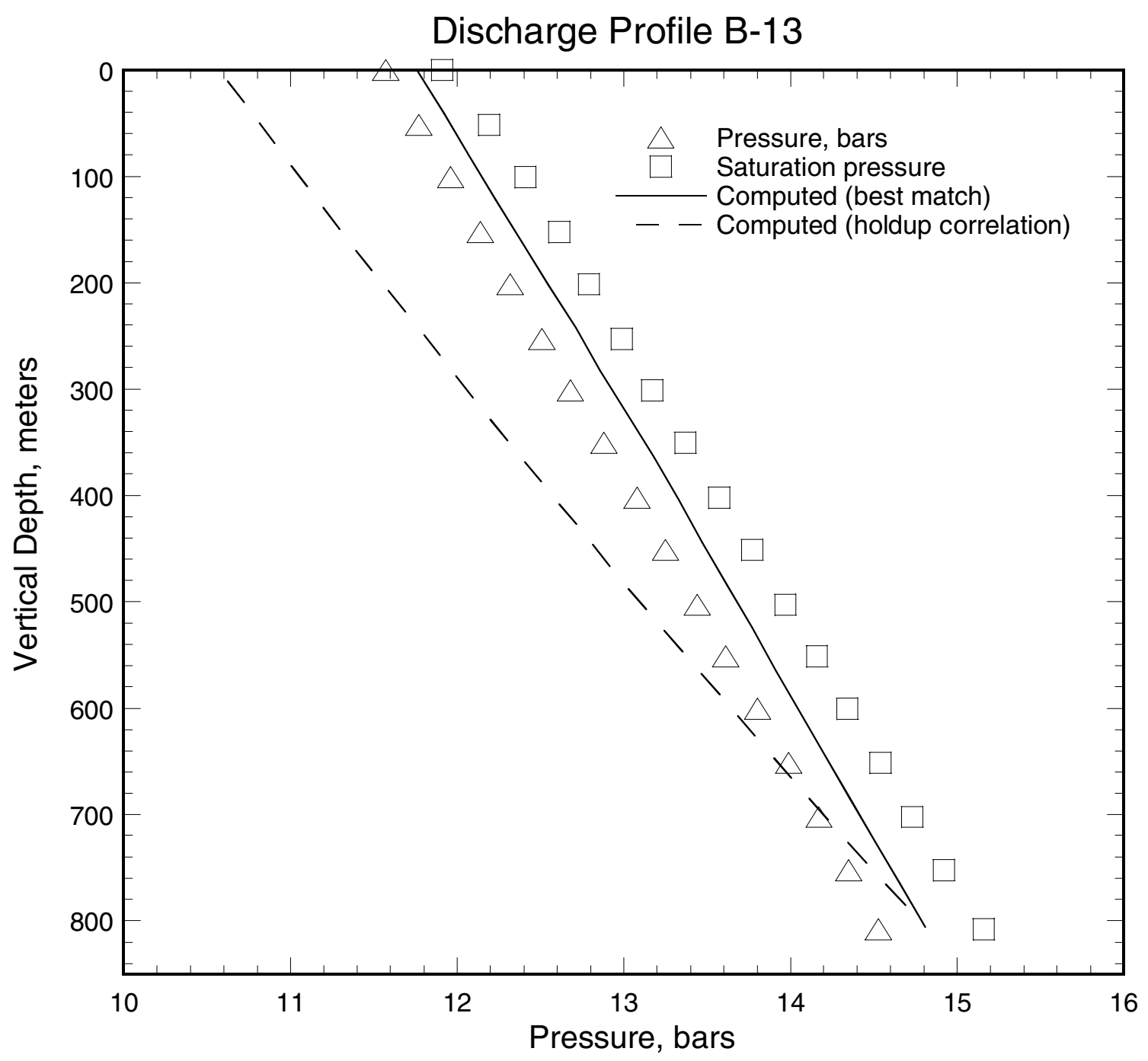

Figure C.21. Pressure profile (triangles) recorded in discharging well B-13. The squares indicate saturation pressure corresponding to the local measured temperature. The solid line is the computed pressure profile using an adjustable holdup correlation (see Section 2 for details). The computed pressure profile using the correlation(s) for $K(Z)$ developed in Section 3 is shown as a dashed line. 


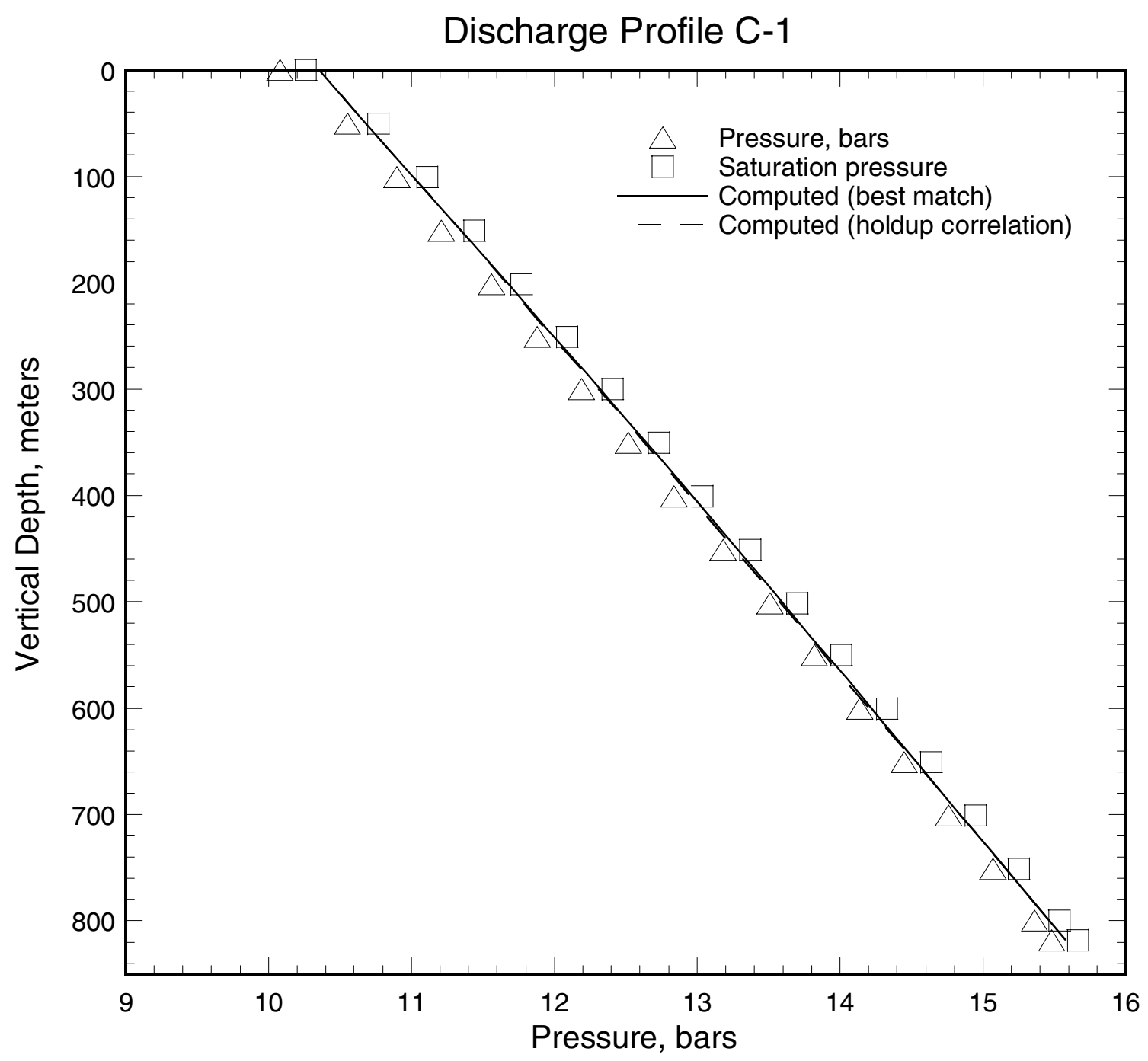

Figure C.22. Pressure profile (triangles) recorded in discharging well C-1. The squares indicate saturation pressure corresponding to the local measured temperature. The solid line is the computed pressure profile using an adjustable holdup correlation (see Section 2 for details). The computed pressure profile using the correlation(s) for $K(Z)$ developed in Section 3 is shown as a dashed line. 


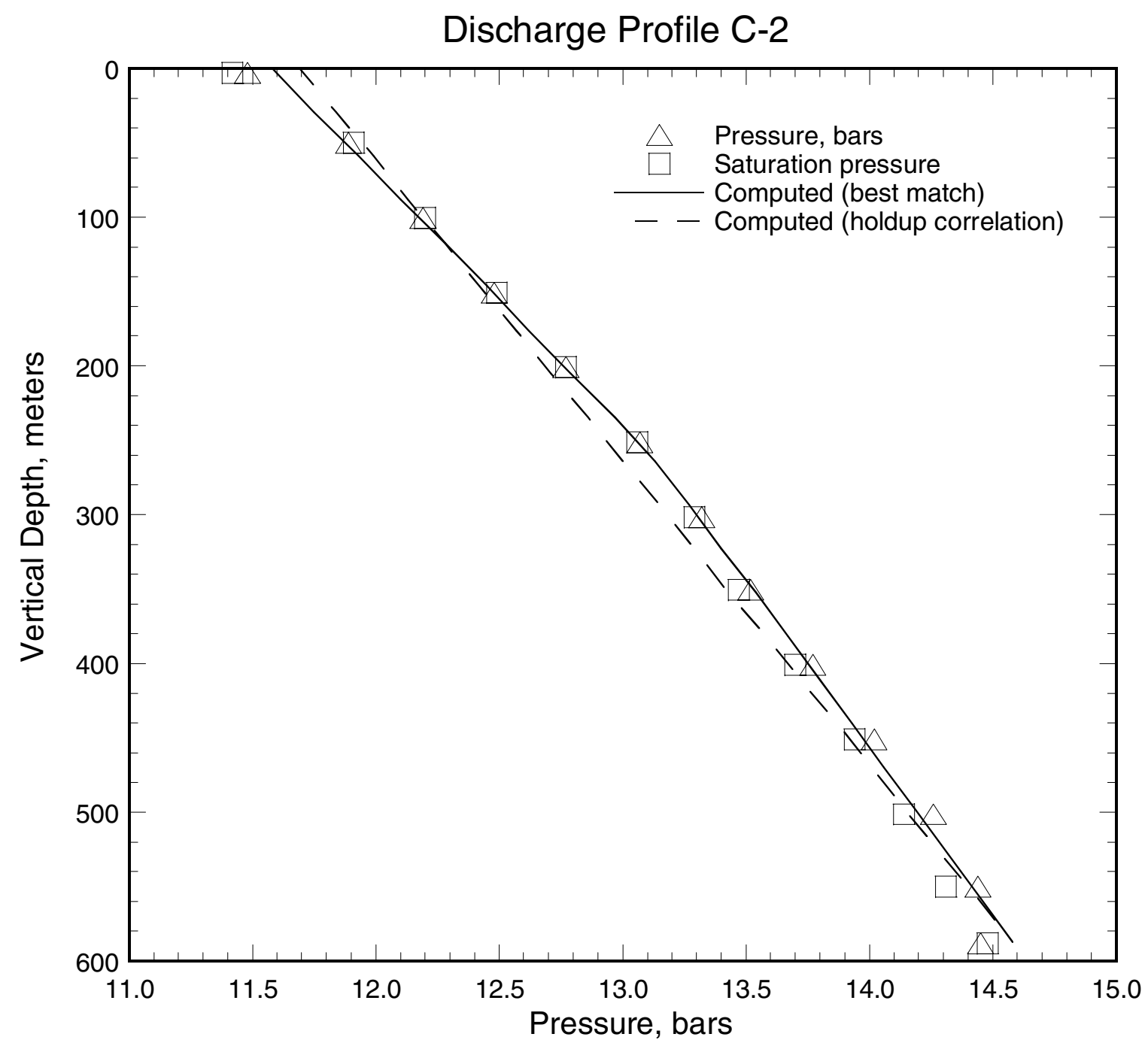

Figure C.23. Pressure profile (triangles) recorded in discharging well C-2. The squares indicate saturation pressure corresponding to the local measured temperature. The solid line is the computed pressure profile using an adjustable holdup correlation (see Section 2 for details). The computed pressure profile using the correlation(s) for $K(Z)$ developed in Section 3 is shown as a dashed line. 
Discharge Profile C-3

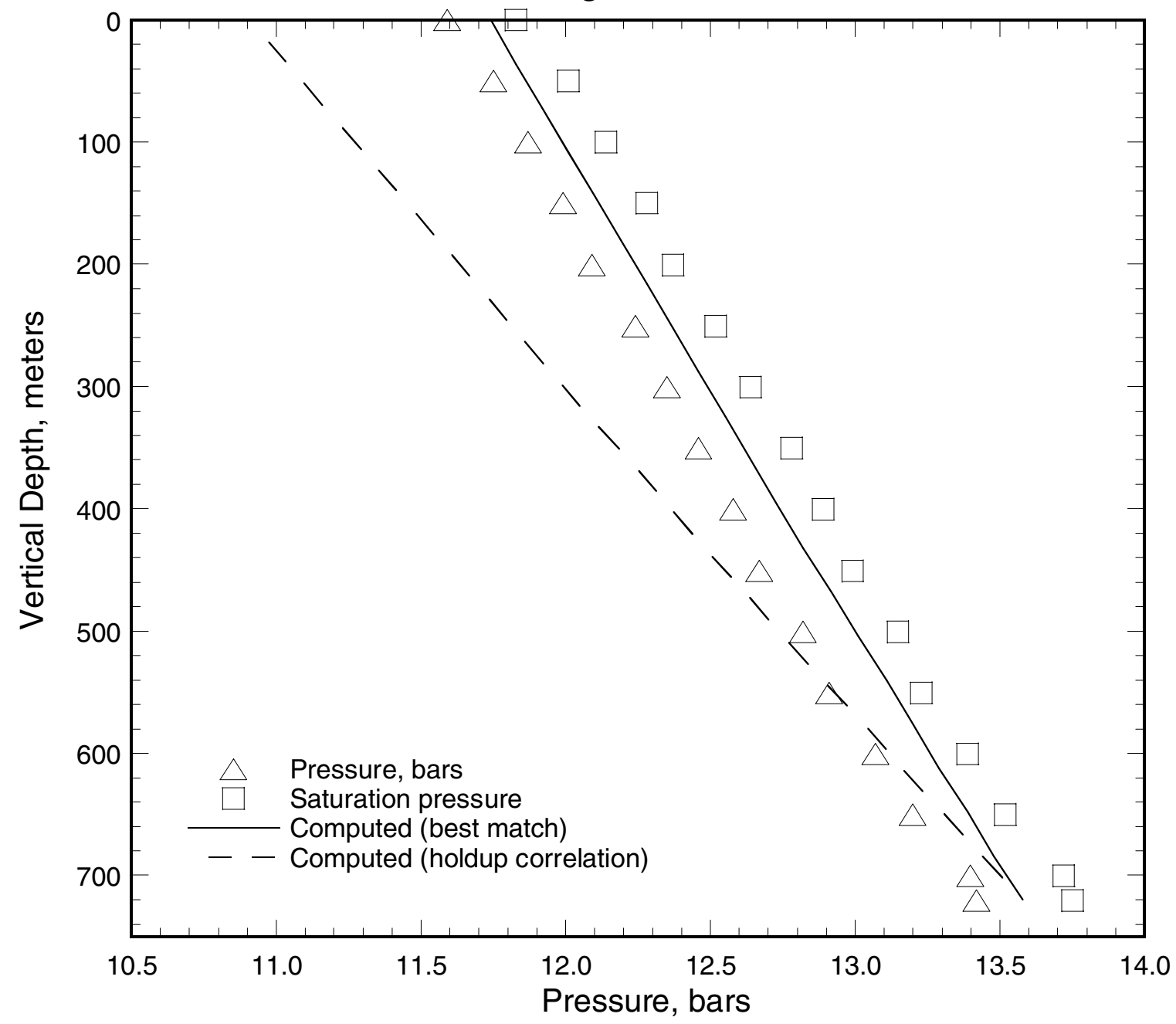

Figure C.24. Pressure profile (triangles) recorded in discharging well C-3. The squares indicate saturation pressure corresponding to the local measured temperature. The solid line is the computed pressure profile using an adjustable holdup correlation (see Section 2 for details). The computed pressure profile using the correlation(s) for $K(Z)$ developed in Section 3 is shown as a dashed line. 


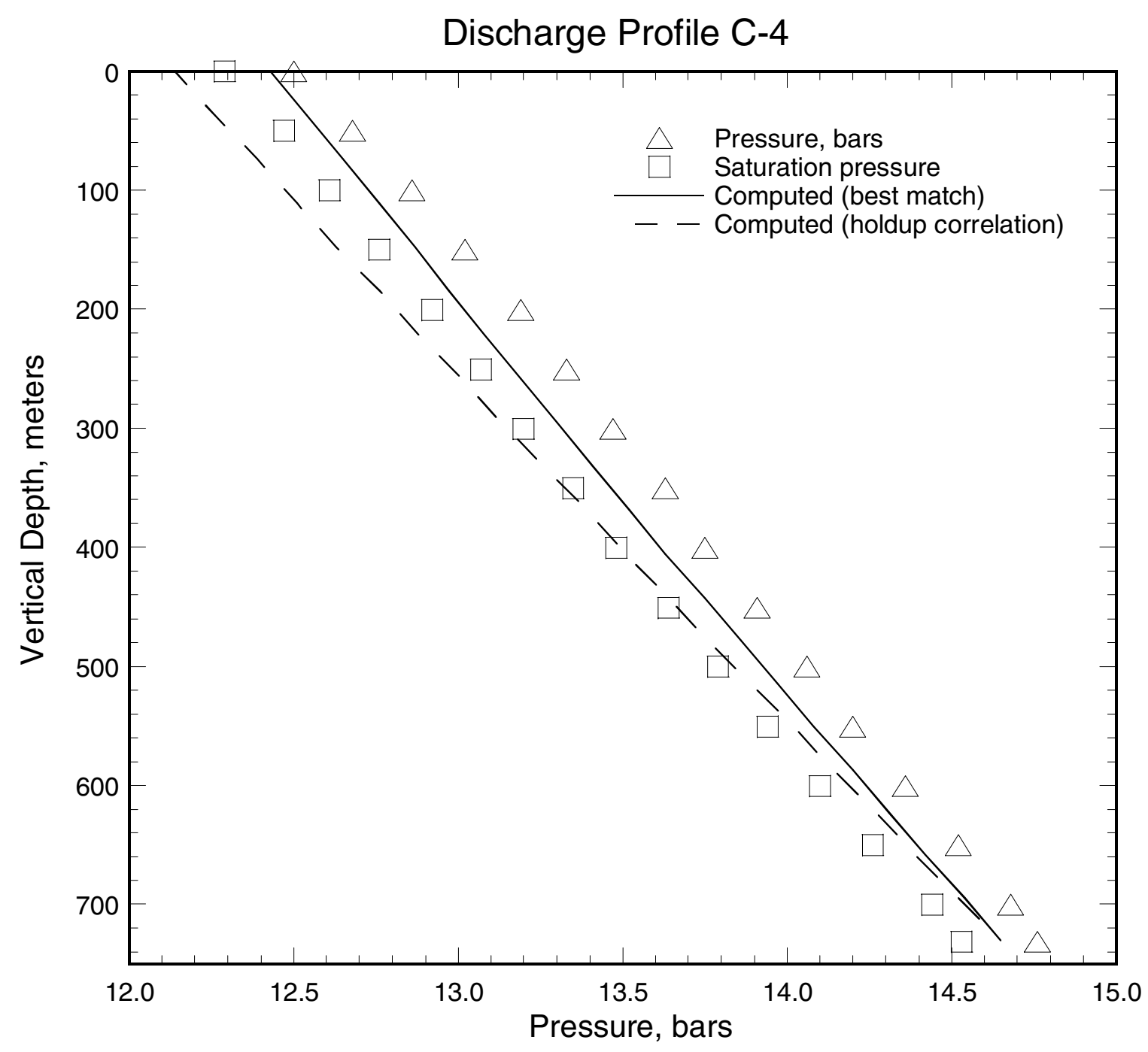

Figure C.25. Pressure profile (triangles) recorded in discharging well C-4. The squares indicate saturation pressure corresponding to the local measured temperature. The solid line is the computed pressure profile using an adjustable holdup correlation (see Section 2 for details). The computed pressure profile using the correlation(s) for $K(Z)$ developed in Section 3 is shown as a dashed line. 


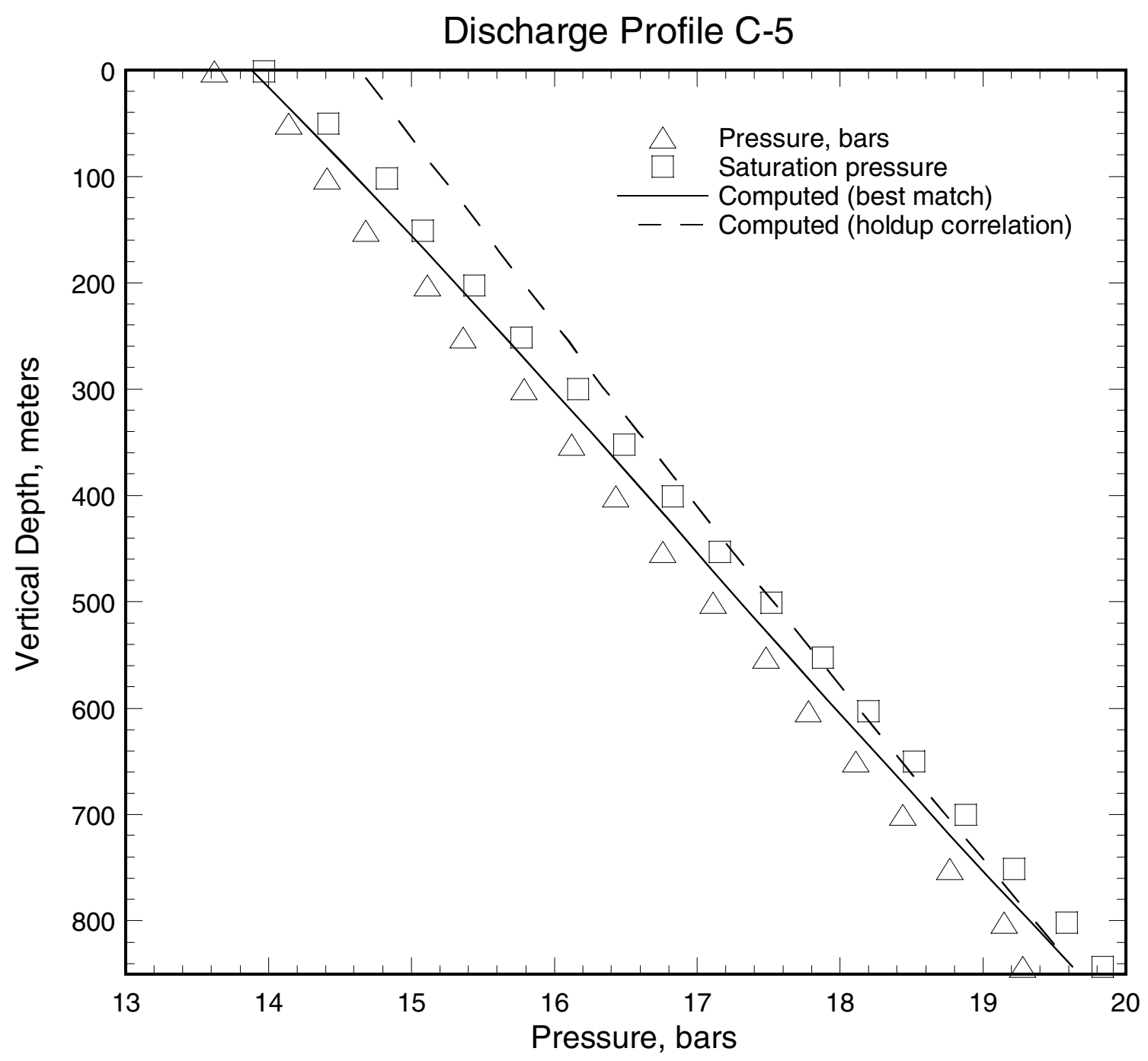

Figure C.26. Pressure profile (triangles) recorded in discharging well C-5. The squares indicate saturation pressure corresponding to the local measured temperature. The solid line is the computed pressure profile using an adjustable holdup correlation (see Section 2 for details). The computed pressure profile using the correlation(s) for $K(Z)$ developed in Section 3 is shown as a dashed line. 


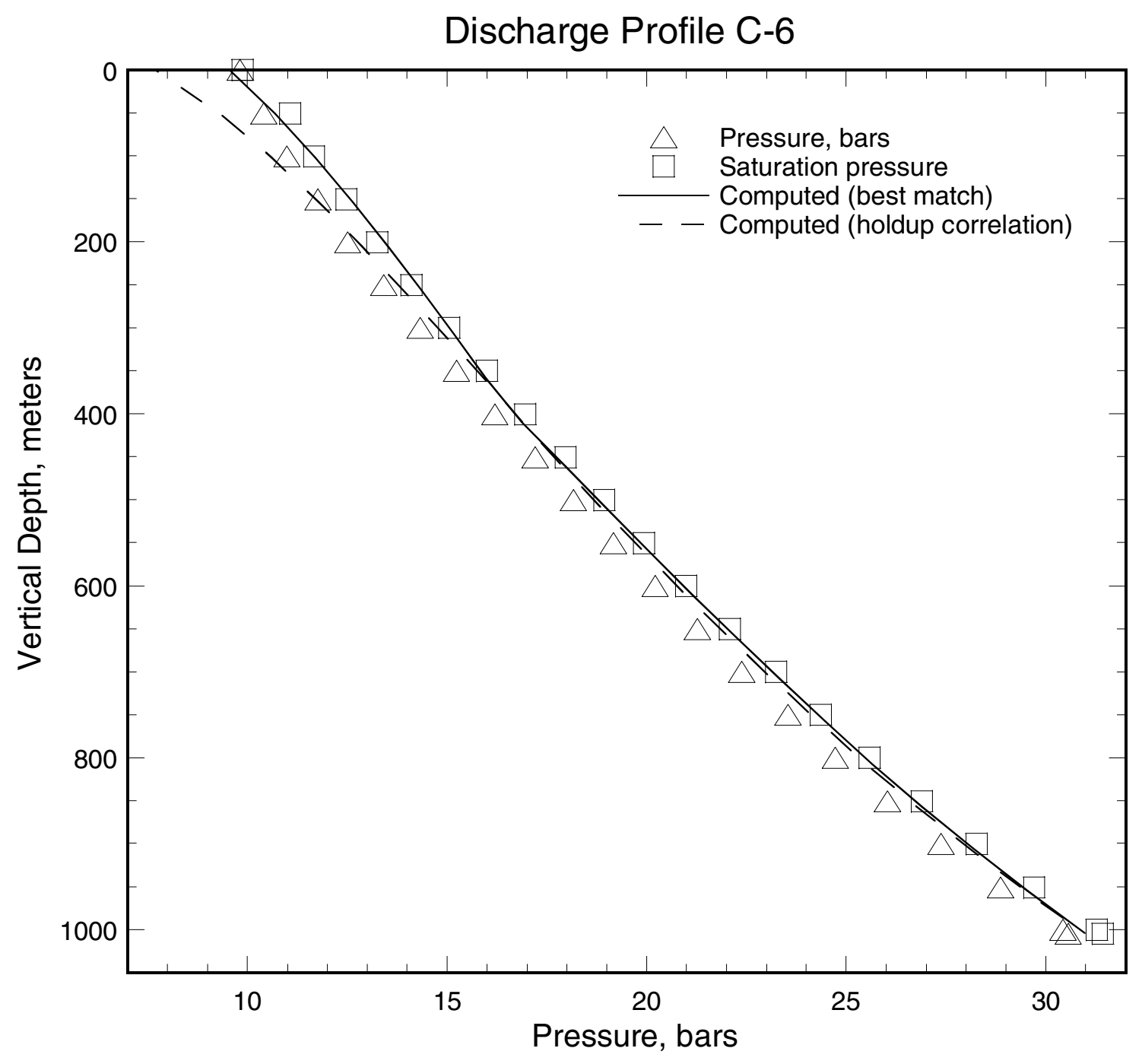

Figure C.27. Pressure profile (triangles) recorded in discharging well C-6. The squares indicate saturation pressure corresponding to the local measured temperature. The solid line is the computed pressure profile using an adjustable holdup correlation (see Section 2 for details). The computed pressure profile using the correlation(s) for $K(Z)$ developed in Section 3 is shown as a dashed line. 
Discharge Profile CS-1

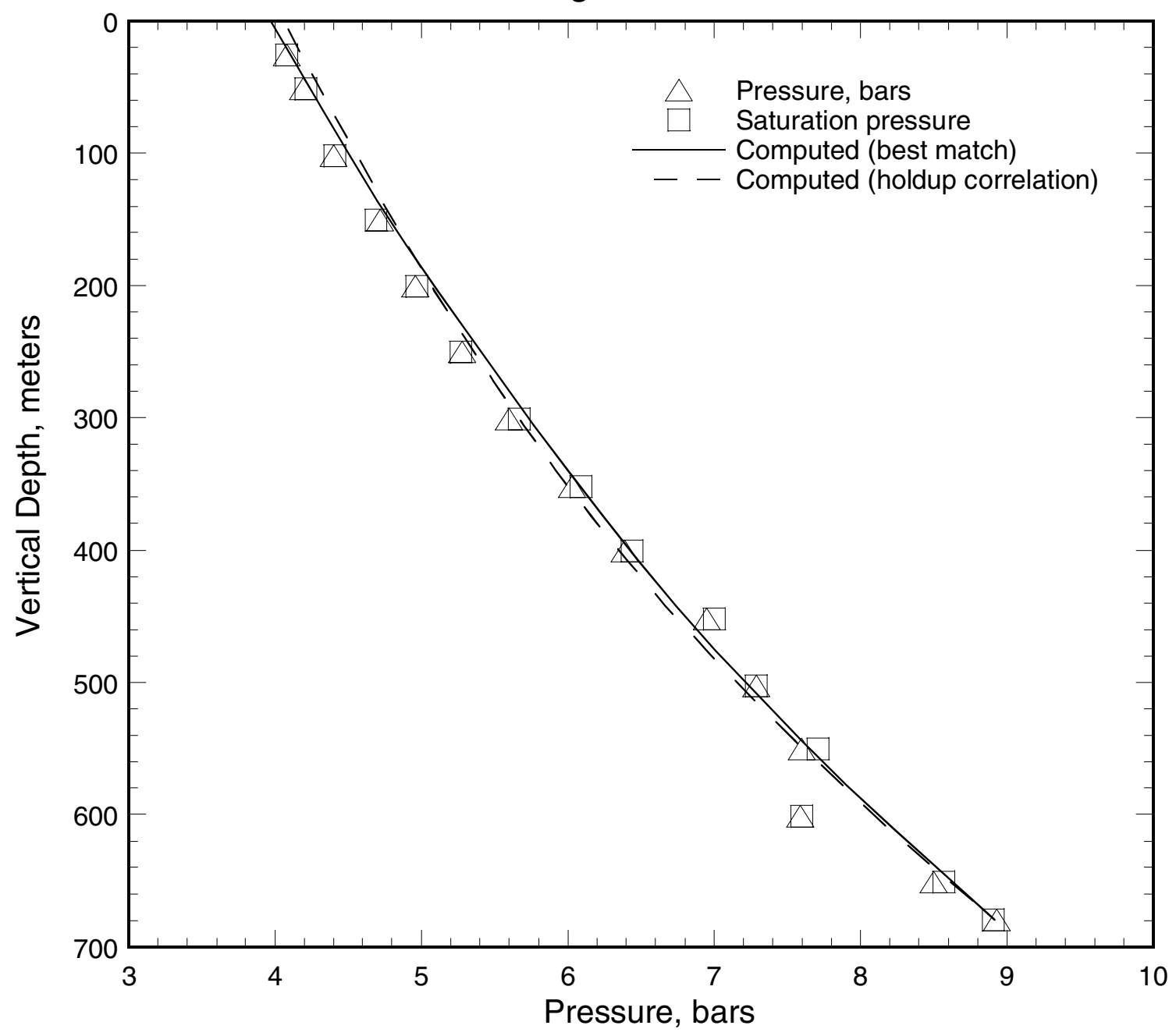

Figure C.28. Pressure profile (triangles) recorded in discharging well CS-1. The squares indicate saturation pressure corresponding to the local measured temperature. The solid line is the computed pressure profile using an adjustable holdup correlation (see Section 2 for details). The computed pressure profile using the correlation(s) for $K(Z)$ developed in Section 3 is shown as a dashed line. 


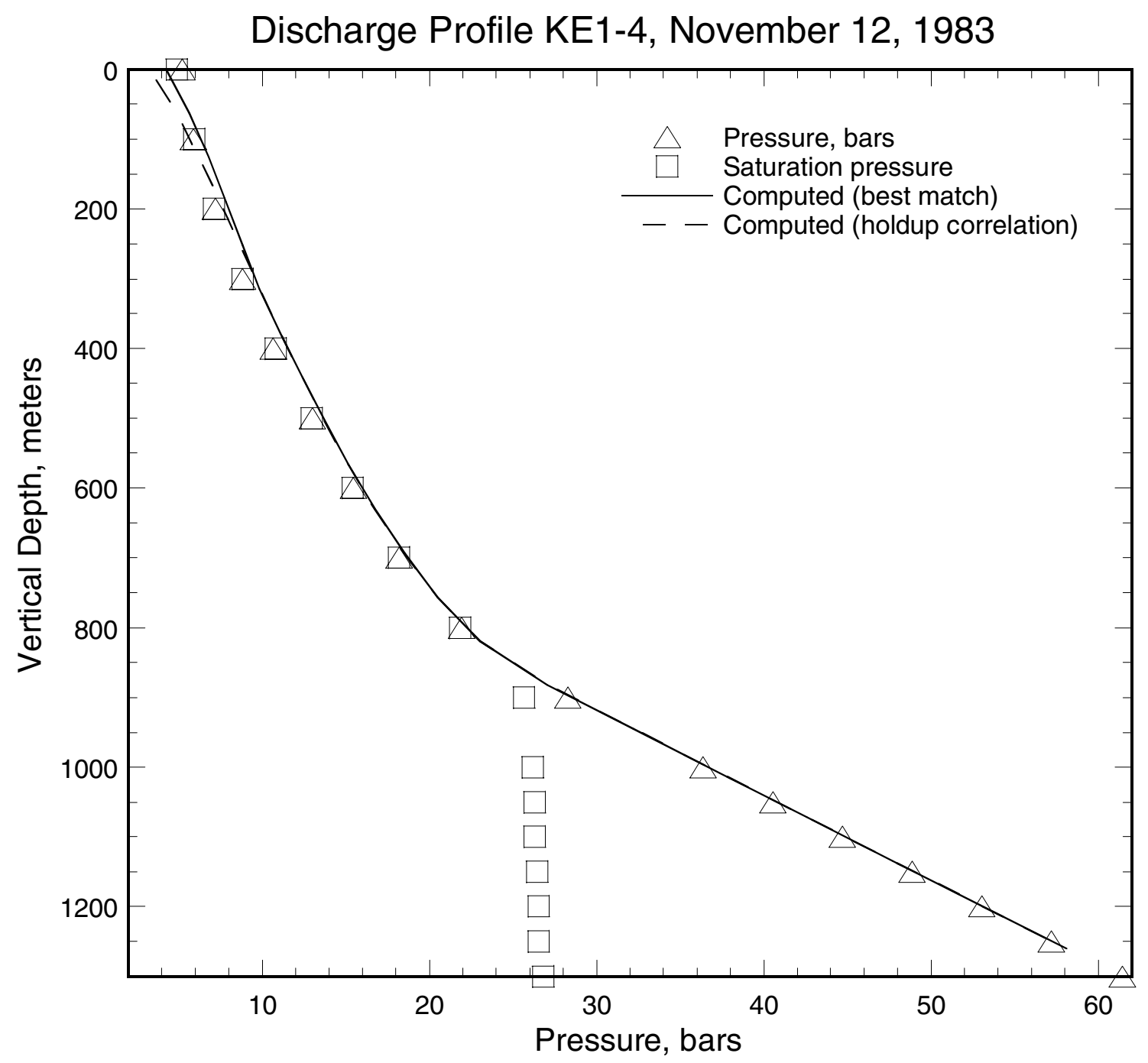

Figure C.29. Pressure profile (triangles) recorded in slim hole KE1-4 on November 12, 1983. The squares indicate saturation pressure corresponding to the local measured temperature. The solid line is the computed pressure profile using an adjustable holdup correlation (see Section 2 for details). The computed pressure profile using the correlation(s) for $K(Z)$ developed in Section 3, shown as a dashed line, was obtained using a reduced discharge rate $(6.5 \mathrm{~kg} / \mathrm{s}$ instead of $7.08 \mathrm{~kg} / \mathrm{s})$. 


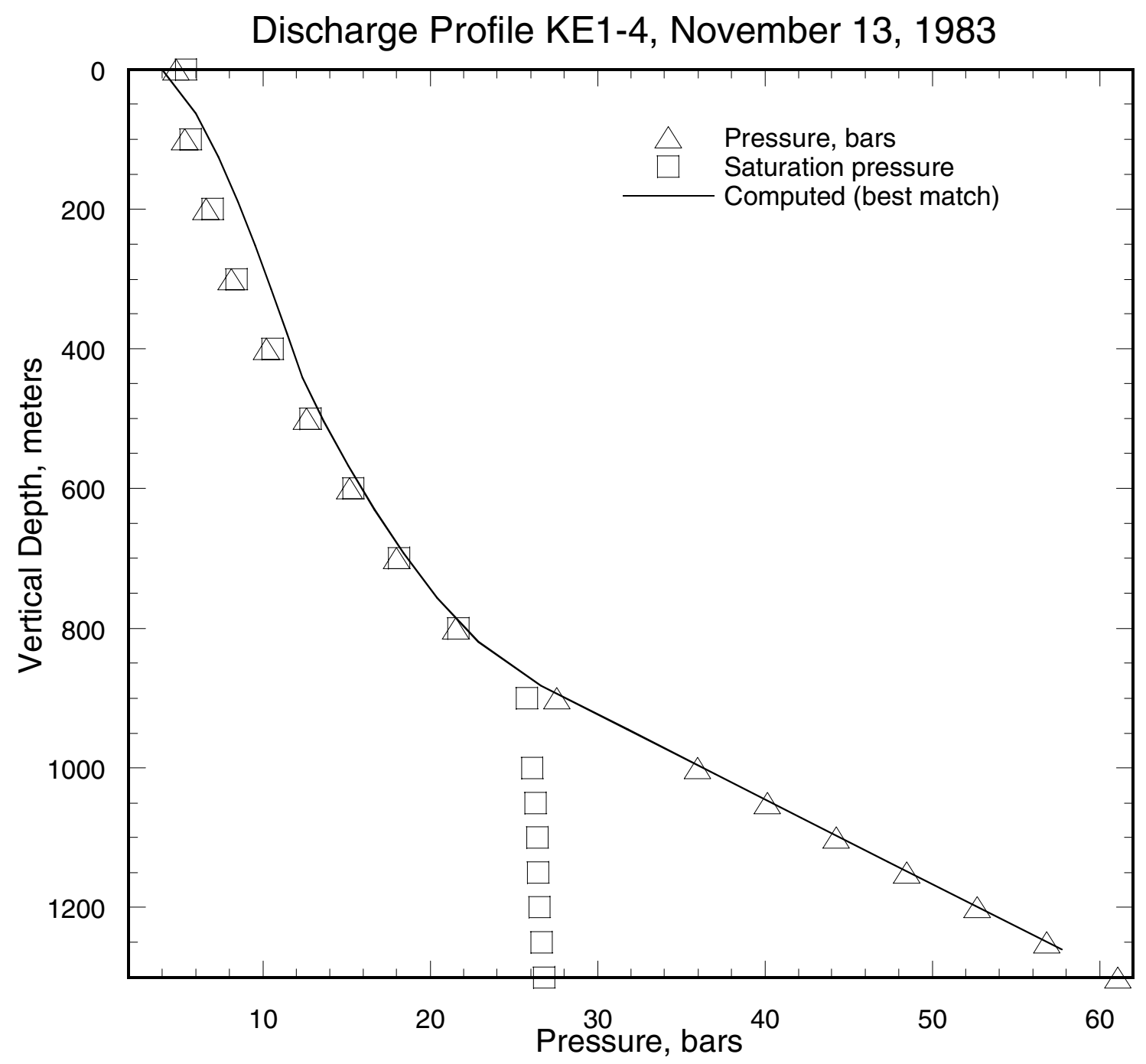

Figure C.30. Pressure profile (triangles) recorded in slim hole KE1-4 on November 13, 1983. The squares indicate saturation pressure corresponding to the local measured temperature. The solid line is the computed pressure profile using an adjustable holdup correlation (see Section 2 for details). The correlation for $K(Z)$ developed in Section 3 results in choking (see Section 3 for details) for discharge rates greater than $6.5 \mathrm{~kg} / \mathrm{s}$; for the computed profile corresponding to the latter discharge rate, see Figure C.29. 


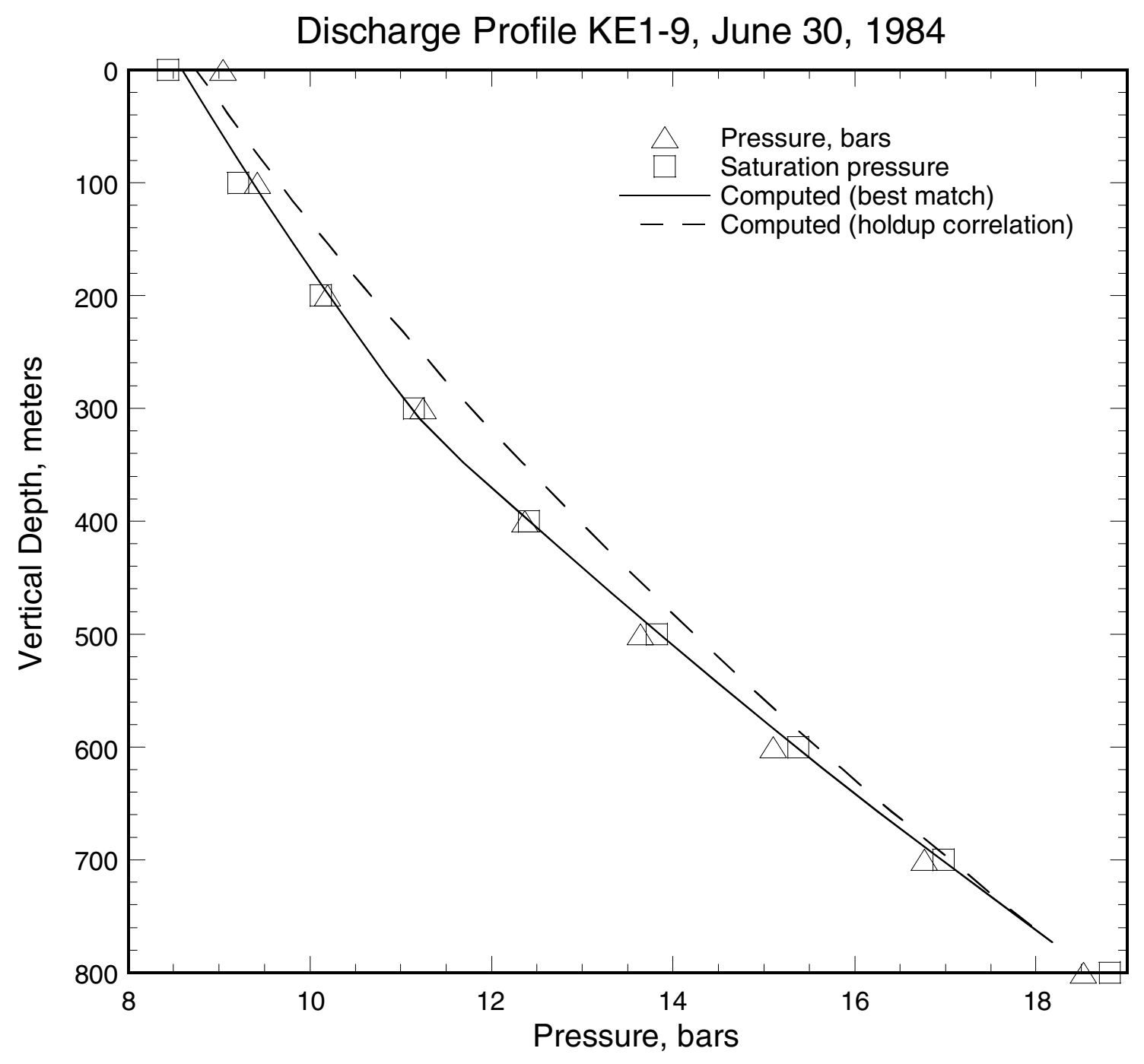

Figure C.31. Pressure profile (triangles) recorded in discharging well KE1-9. The squares indicate saturation pressure corresponding to the local measured temperature. The solid line is the computed pressure profile using an adjustable holdup correlation (see Section 2 for details). The computed pressure profile using the correlation(s) for $K(Z)$ developed in Section 3 is shown as a dashed line. 


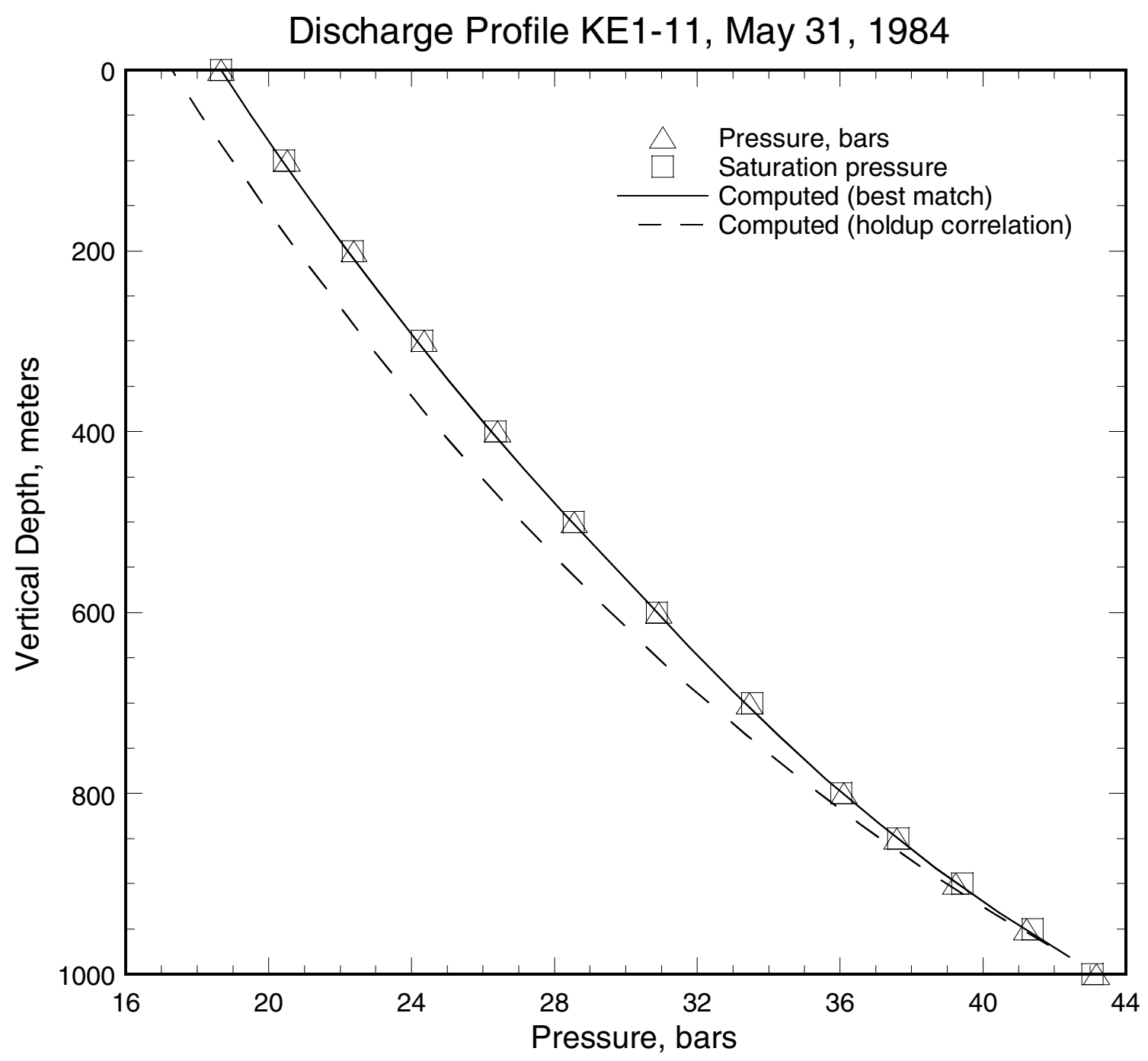

Figure C.32. Pressure profile (triangles) recorded in discharging well KE1-11. The squares indicate saturation pressure corresponding to the local measured temperature. The solid line is the computed pressure profile using an adjustable holdup correlation (see Section 2 for details). The computed pressure profile using the correlation(s) for $K(Z)$ developed in Section 3 is shown as a dashed line. 


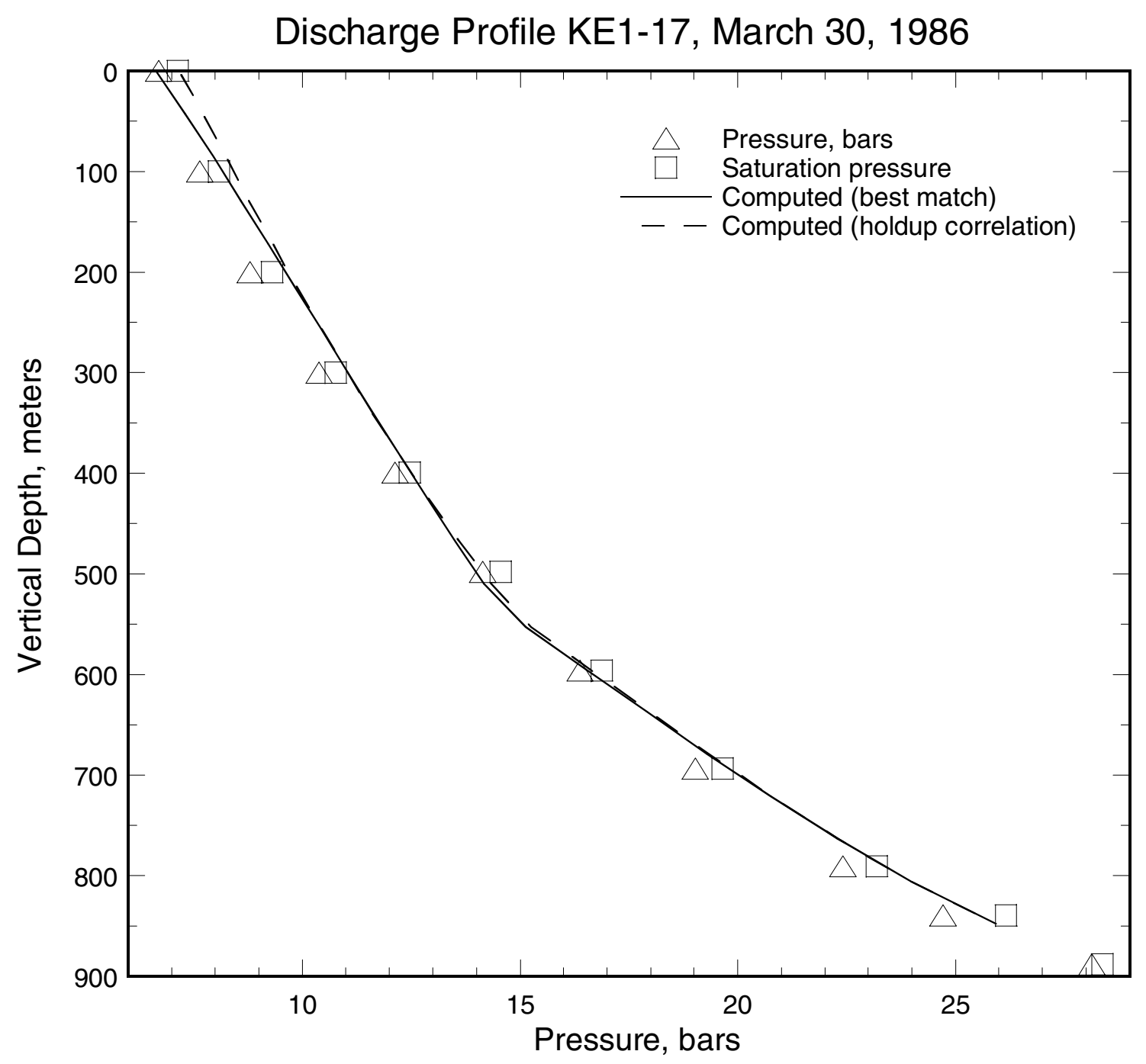

Figure C.33. Pressure profile (triangles) recorded in well KE1-17 on March 30, 1986. The squares indicate saturation pressure corresponding to the local measured temperature. The solid line is the computed pressure profile using an adjustable holdup correlation (see Section 2 for details). The computed pressure profile using the correlation(s) for $K(Z)$ developed in Section 3 is shown as a dashed line. 


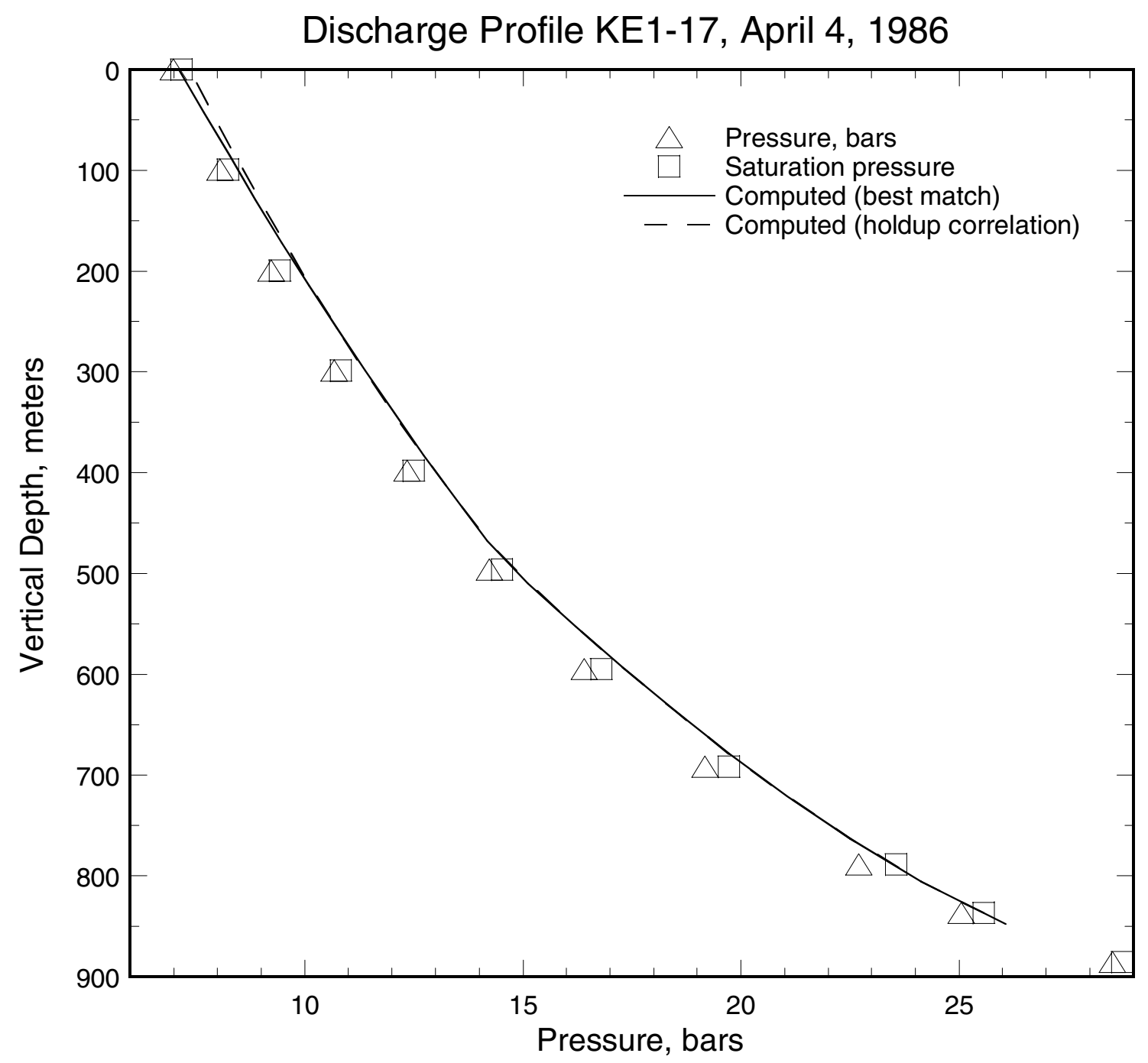

Figure C.34. Pressure profile (triangles) recorded in well KE1-17 on April 4, 1986. The squares indicate saturation pressure corresponding to the local measured temperature. The solid line is the computed pressure profile using an adjustable holdup correlation (see Section 2 for details). The computed pressure profile using the correlation(s) for $K(Z)$ developed in Section 3 is shown as a dashed line. 


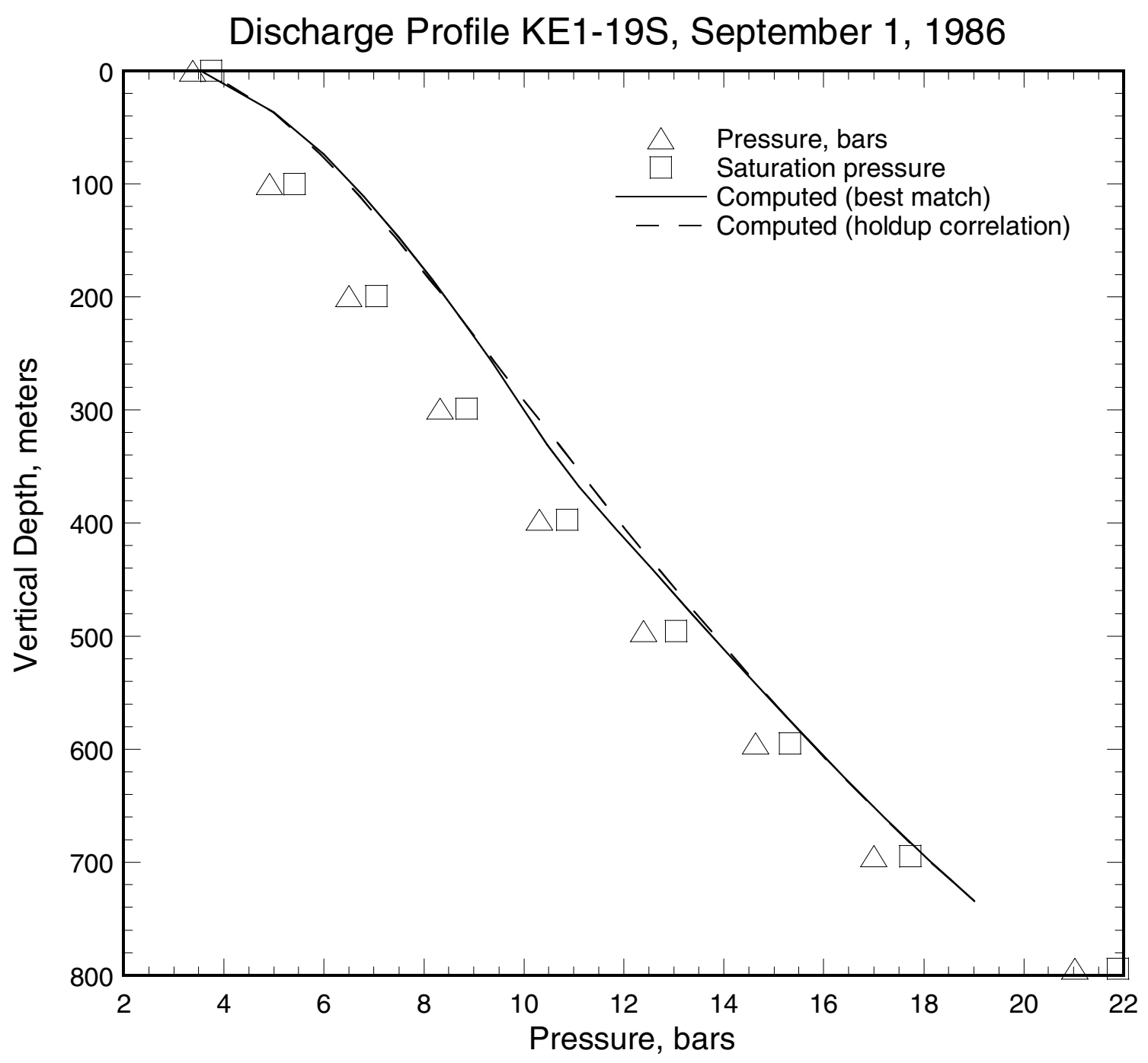

Figure C.35. Pressure profile (triangles) recorded in well KE1-19S on September 1, 1986. The squares indicate saturation pressure corresponding to the local measured temperature. The solid line is the computed pressure profile using an adjustable holdup correlation (see Section 2 for details). The computed pressure profile using the correlation(s) for $K(Z)$ developed in Section 3, shown as a dashed line, was obtained using a reduced discharge rate $(23.0 \mathrm{~kg} / \mathrm{s}$ instead of $23.9 \mathrm{~kg} / \mathrm{s})$. 


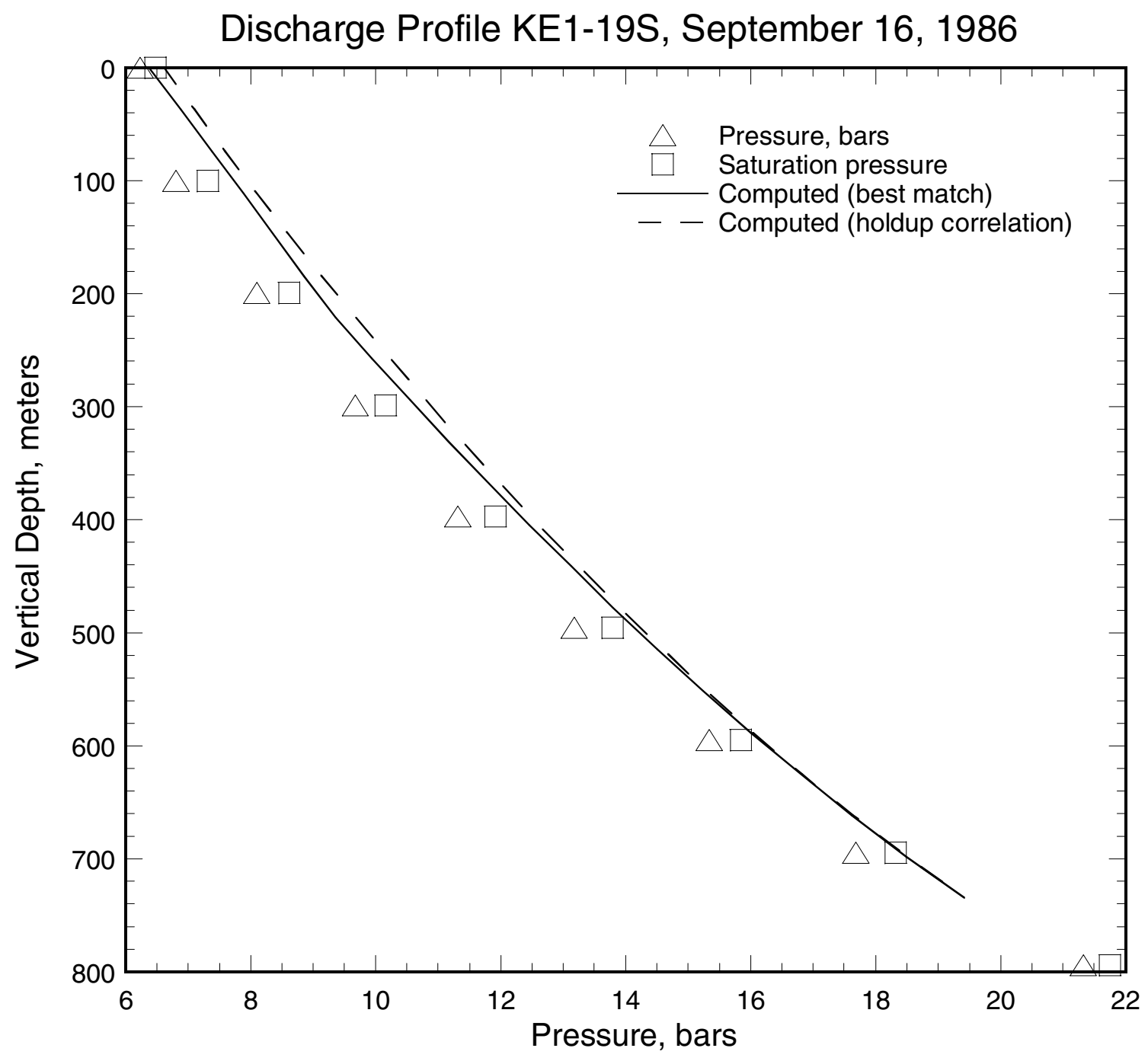

Figure C.36. Pressure profile (triangles) recorded in well KE1-19S on September 16, 1986. The squares indicate saturation pressure corresponding to the local measured temperature. The solid line is the computed pressure profile using an adjustable holdup correlation (see Section 2 for details). The computed pressure profile using the correlation(s) for $K(Z)$ developed in Section 3 is shown as a dashed line. 


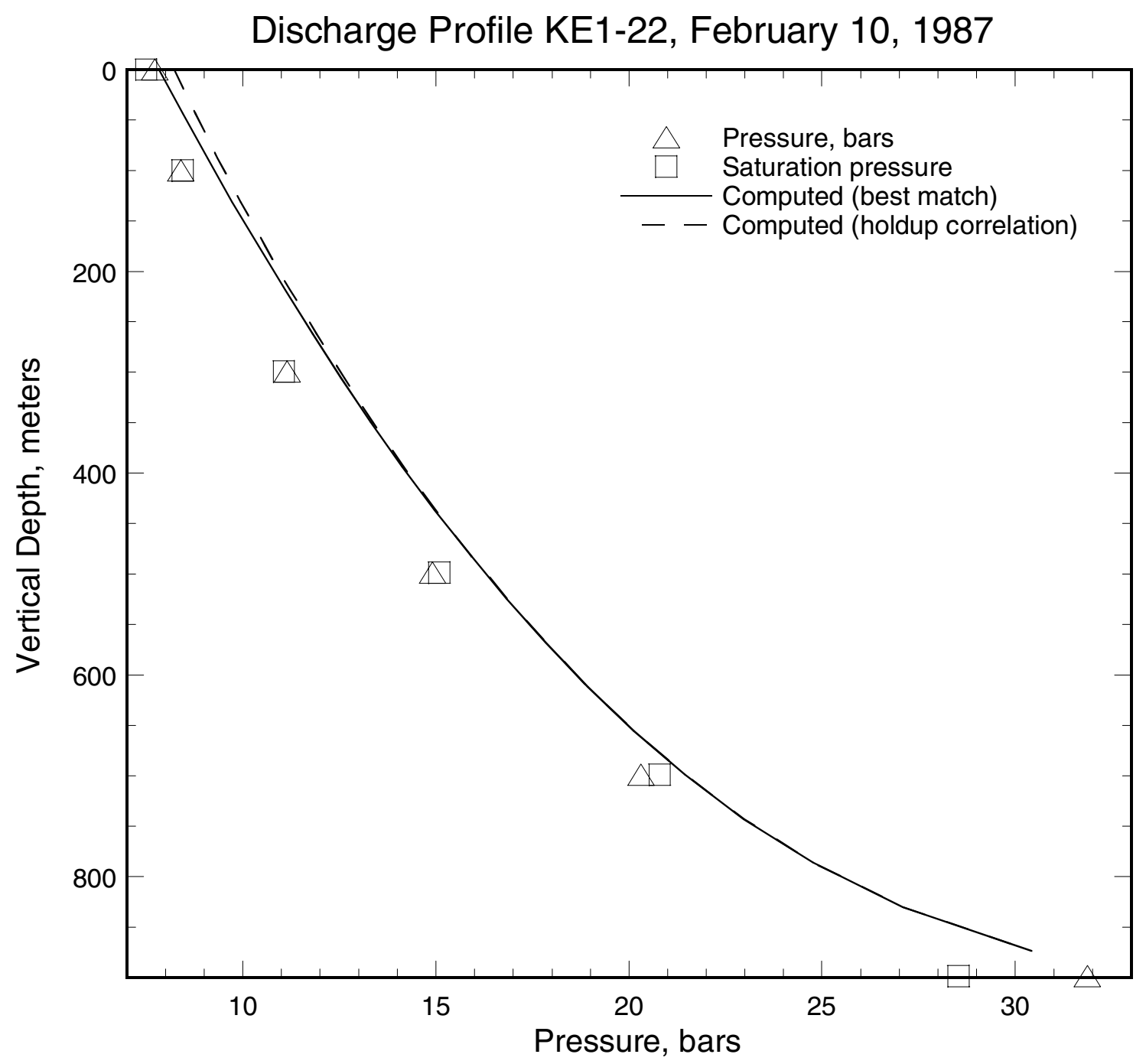

Figure C.37. Pressure profile (triangles) recorded in well KE1-22 on February 10, 1987. The squares indicate saturation pressure corresponding to the local measured temperature. The solid line is the computed pressure profile using an adjustable holdup correlation (see Section 2 for details). The computed pressure profile using the correlation(s) for $K(Z)$ developed in Section 3 is shown as a dashed line. 


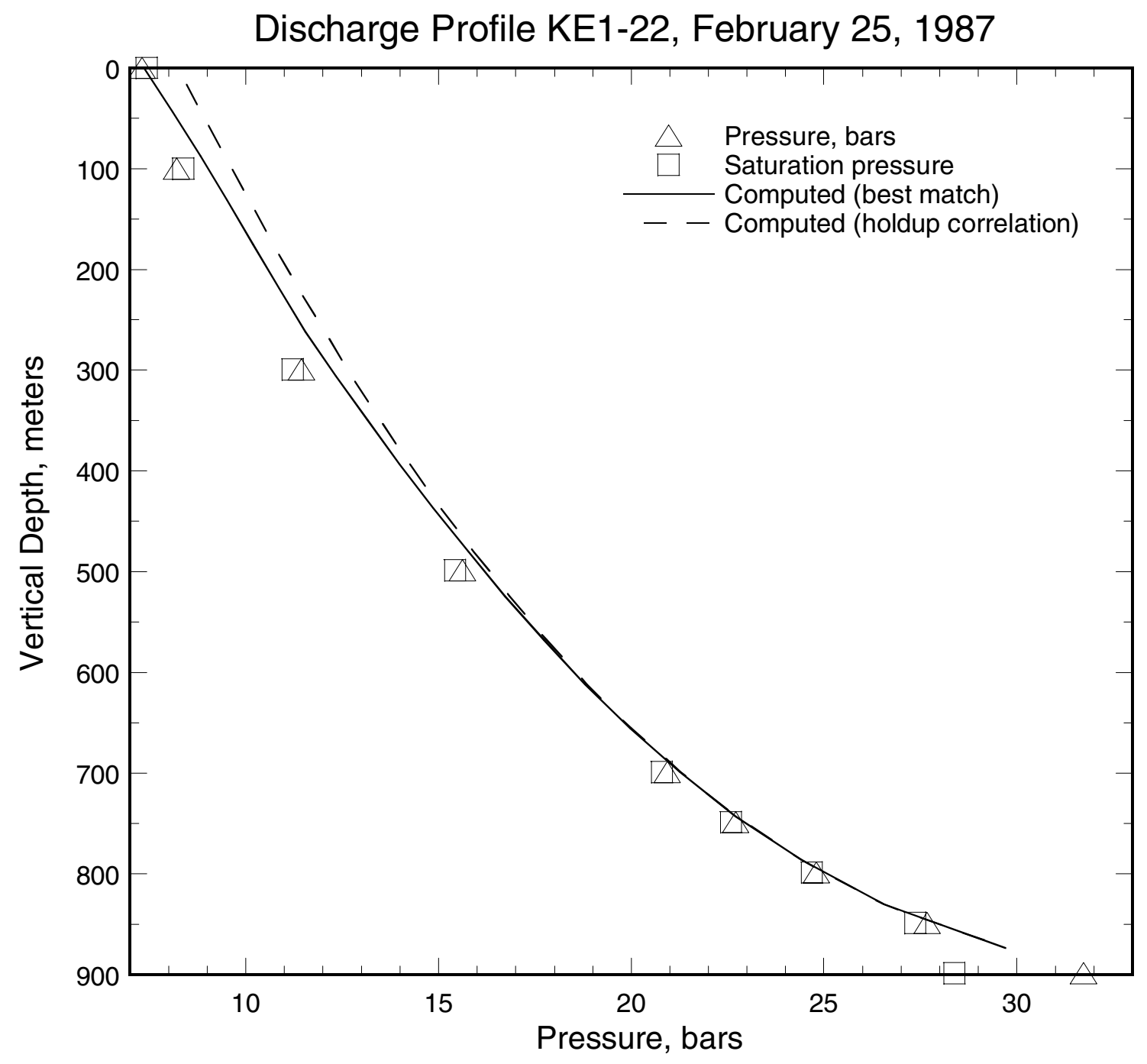

Figure C.38. Pressure profile (triangles) recorded in well KE1-22 on February 25, 1987. The squares indicate saturation pressure corresponding to the local measured temperature. The solid line is the computed pressure profile using an adjustable holdup correlation (see Section 2 for details). The computed pressure profile using the correlation(s) for $K(Z)$ developed in Section 3 is shown as a dashed line. 


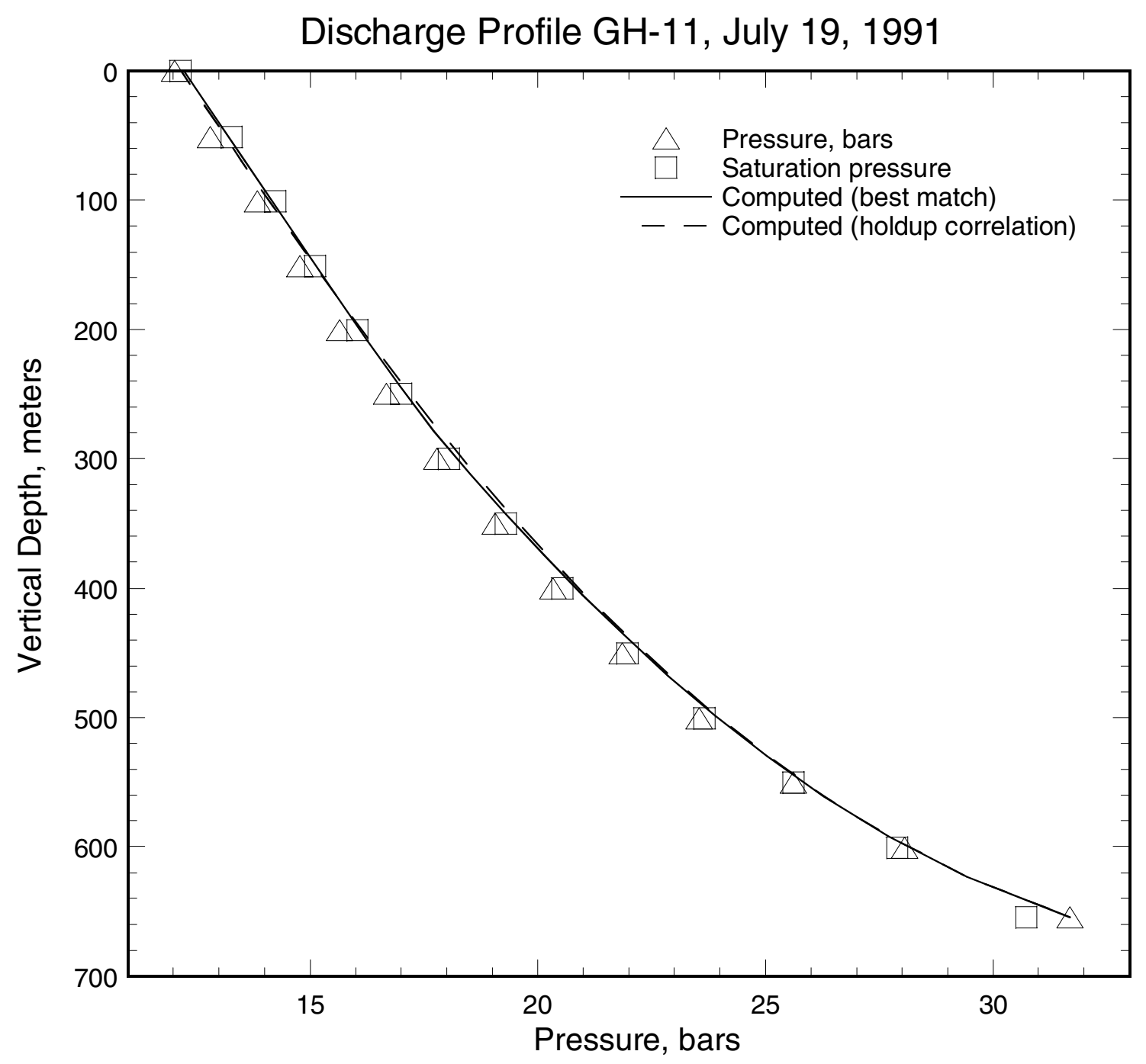

Figure C.39. Pressure profile (triangles) recorded in well GH-11 on July 19, 1991. The squares indicate saturation pressure corresponding to the local measured temperature. The solid line is the computed pressure profile using an adjustable holdup correlation (see Section 2 for details). The computed pressure profile using the correlation(s) for $K(Z)$ developed in Section 3 is shown as a dashed line. 
Discharge Profile GH-11, July 20, 1991

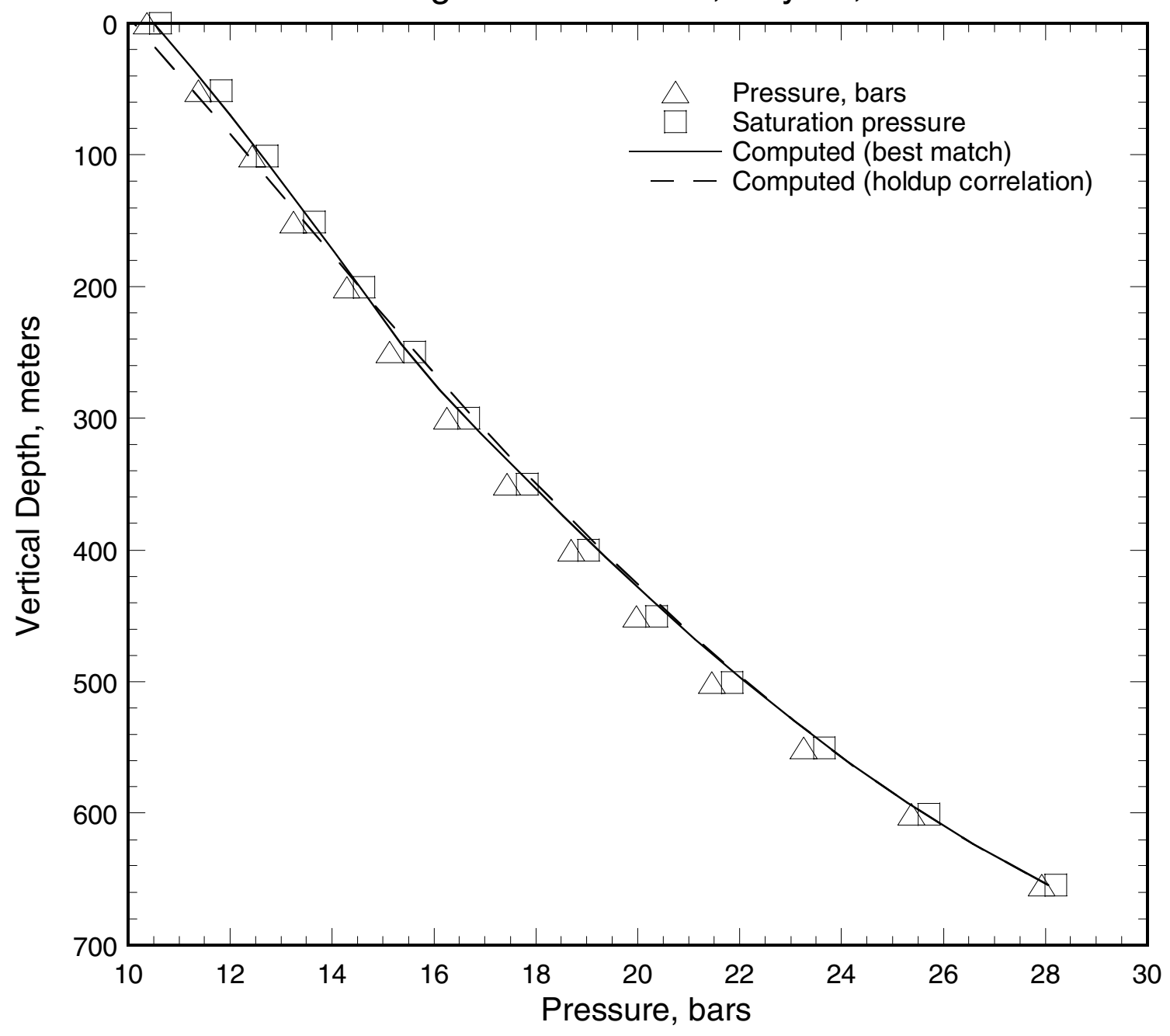

Figure C.40. Pressure profile (triangles) recorded in well GH-11 on July 20, 1991. The squares indicate saturation pressure corresponding to the local measured temperature. The solid line is the computed pressure profile using an adjustable holdup correlation (see Section 2 for details). The computed pressure profile using the correlation(s) for $K(Z)$ developed in Section 3 is shown as a dashed line. 


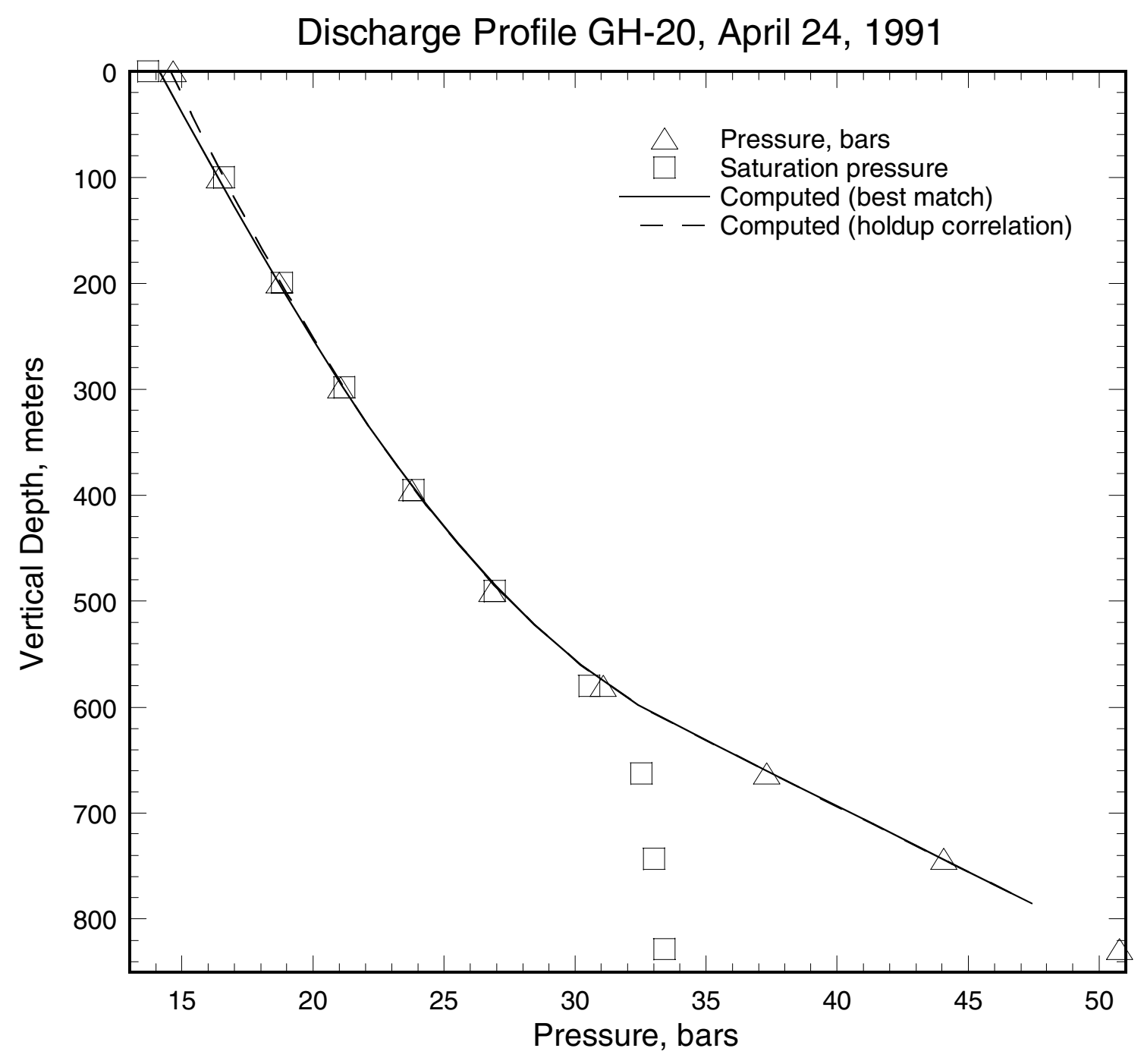

Figure C.41. Pressure profile (triangles) recorded in well GH-20 on April 24, 1991. The squares indicate saturation pressure corresponding to the local measured temperature. The solid line is the computed pressure profile using an adjustable holdup correlation (see Section 2 for details). The computed pressure profile using the correlation(s) for $K(Z)$ developed in Section 3 is shown as a dashed line. 


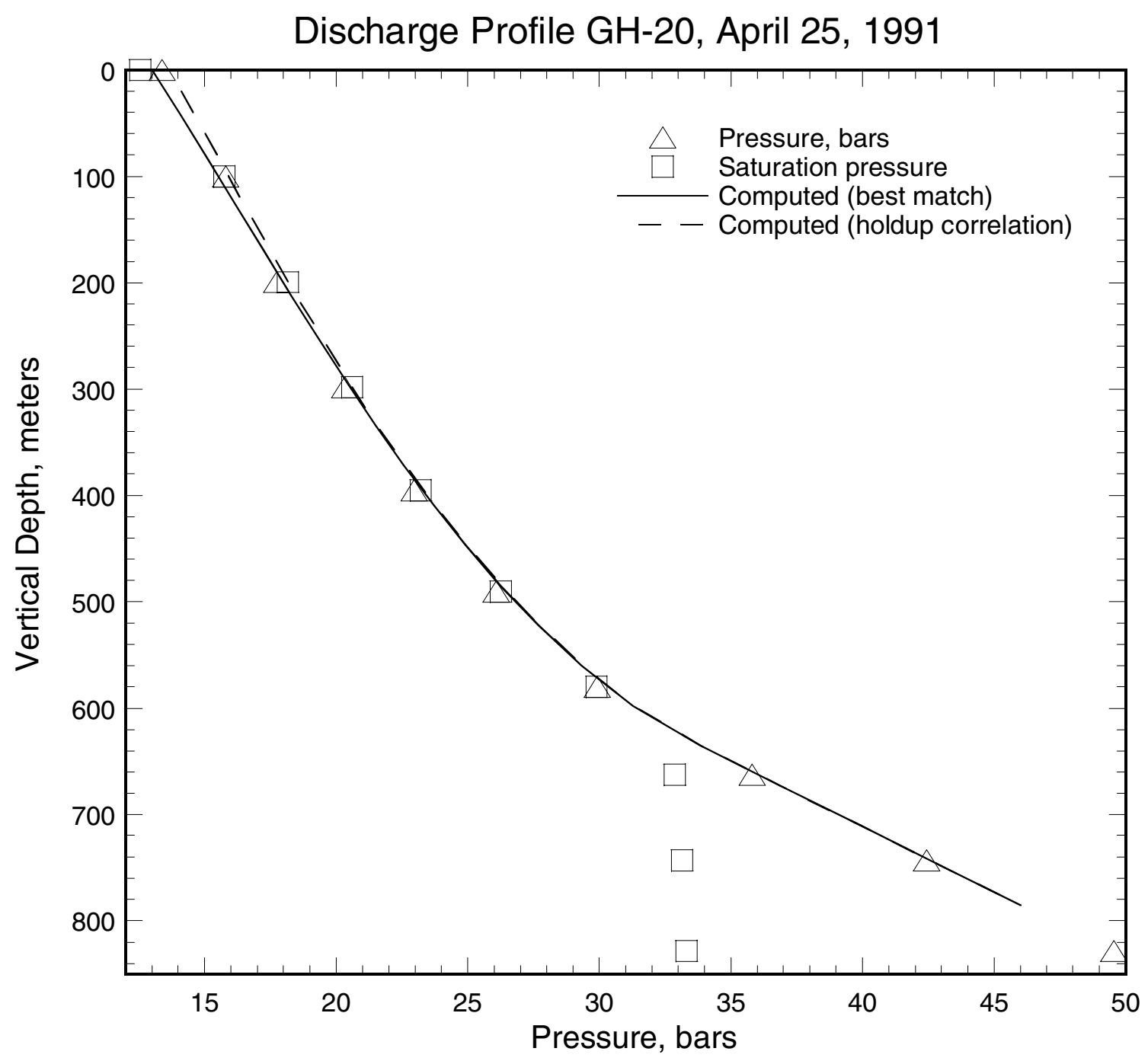

Figure C.42. Pressure profile (triangles) recorded in well GH-20 on April 25, 1991. The squares indicate saturation pressure corresponding to the local measured temperature. The solid line is the computed pressure profile using an adjustable holdup correlation (see Section 2 for details). The computed pressure profile using the correlation(s) for $K(Z)$ developed in Section 3 is shown as a dashed line. 


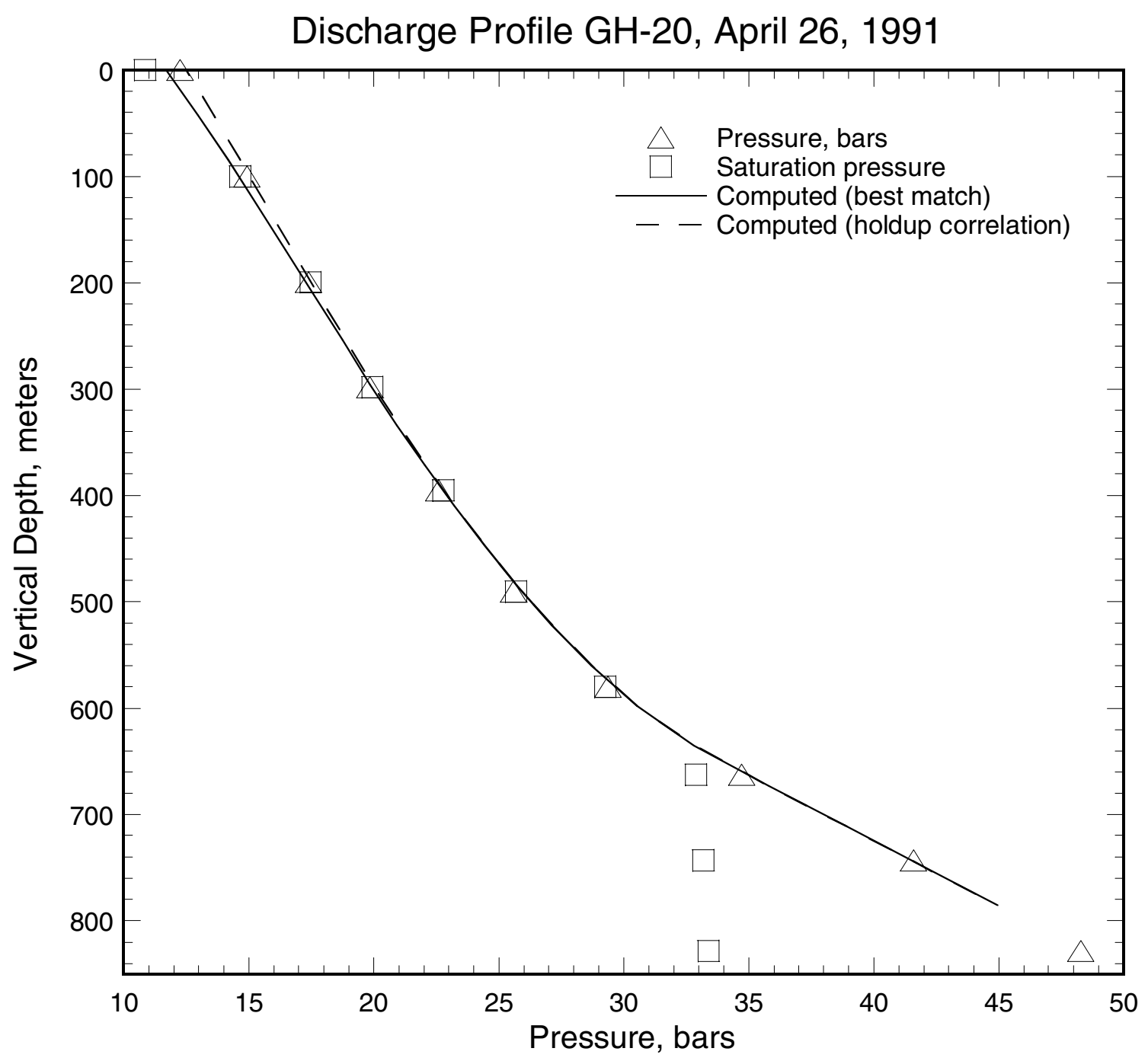

Figure C.43. Pressure profile (triangles) recorded in well GH-20 on April 26, 1991. The squares indicate saturation pressure corresponding to the local measured temperature. The solid line is the computed pressure profile using an adjustable holdup correlation (see Section 2 for details). The computed pressure profile using the correlation(s) for $K(Z)$ developed in Section 3 is shown as a dashed line. 


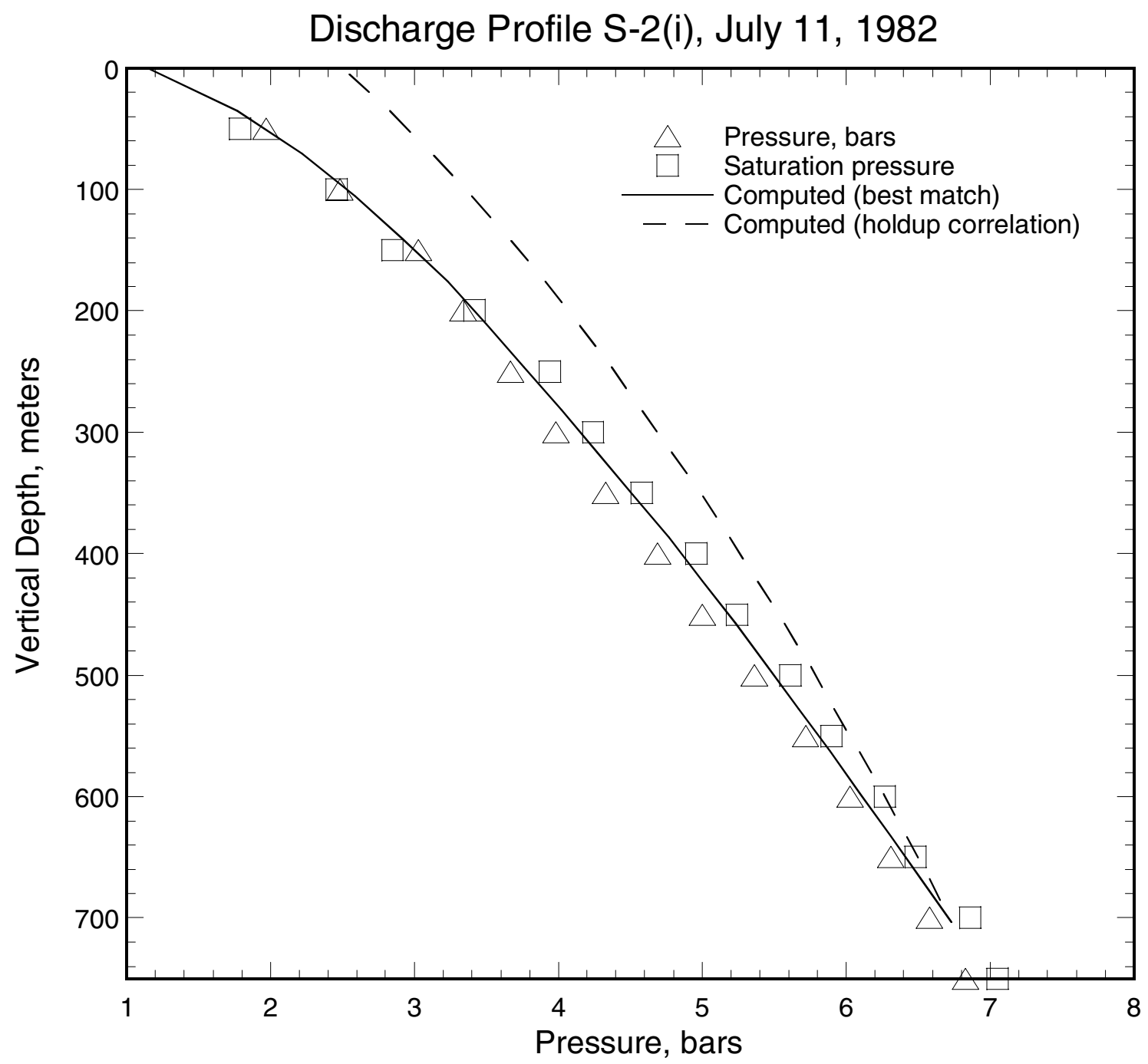

Figure C.44. Pressure profile (triangles) recorded in discharging well $\mathrm{S}-2(\mathrm{i})$. The squares indicate saturation pressure corresponding to the local measured temperature. The solid line is the computed pressure profile using an adjustable holdup correlation (see Section 2 for details). The computed pressure profile using the correlation(s) for $K(Z)$ developed in Section 3 is shown as a dashed line. 


\section{APPENDIX D: SIMULATION OF SPINNER DATA}

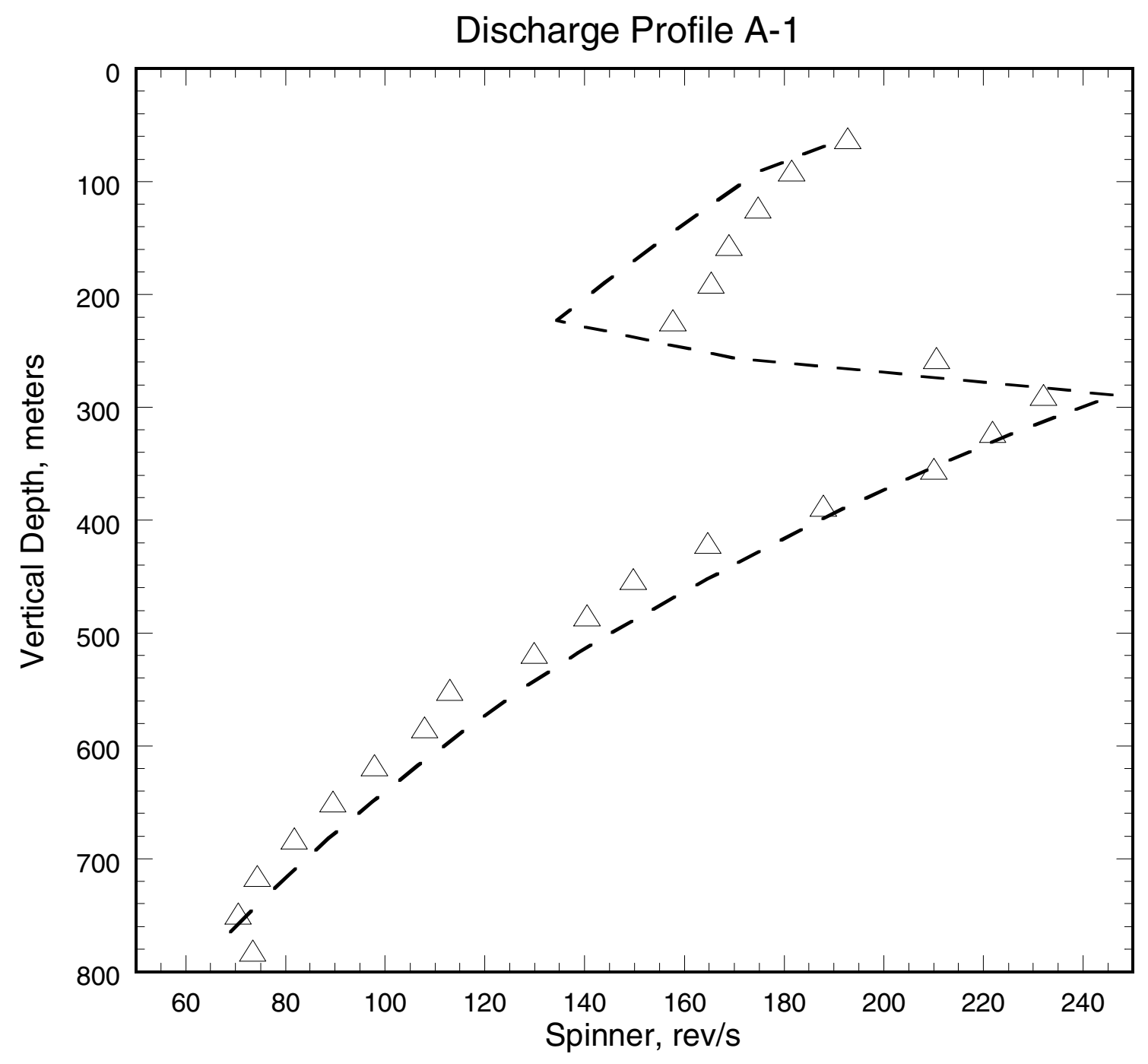

Figure D.1. Comparison of the smoothed spinner response (triangles) with the computed spinner response (dashed line) for well A-1. 


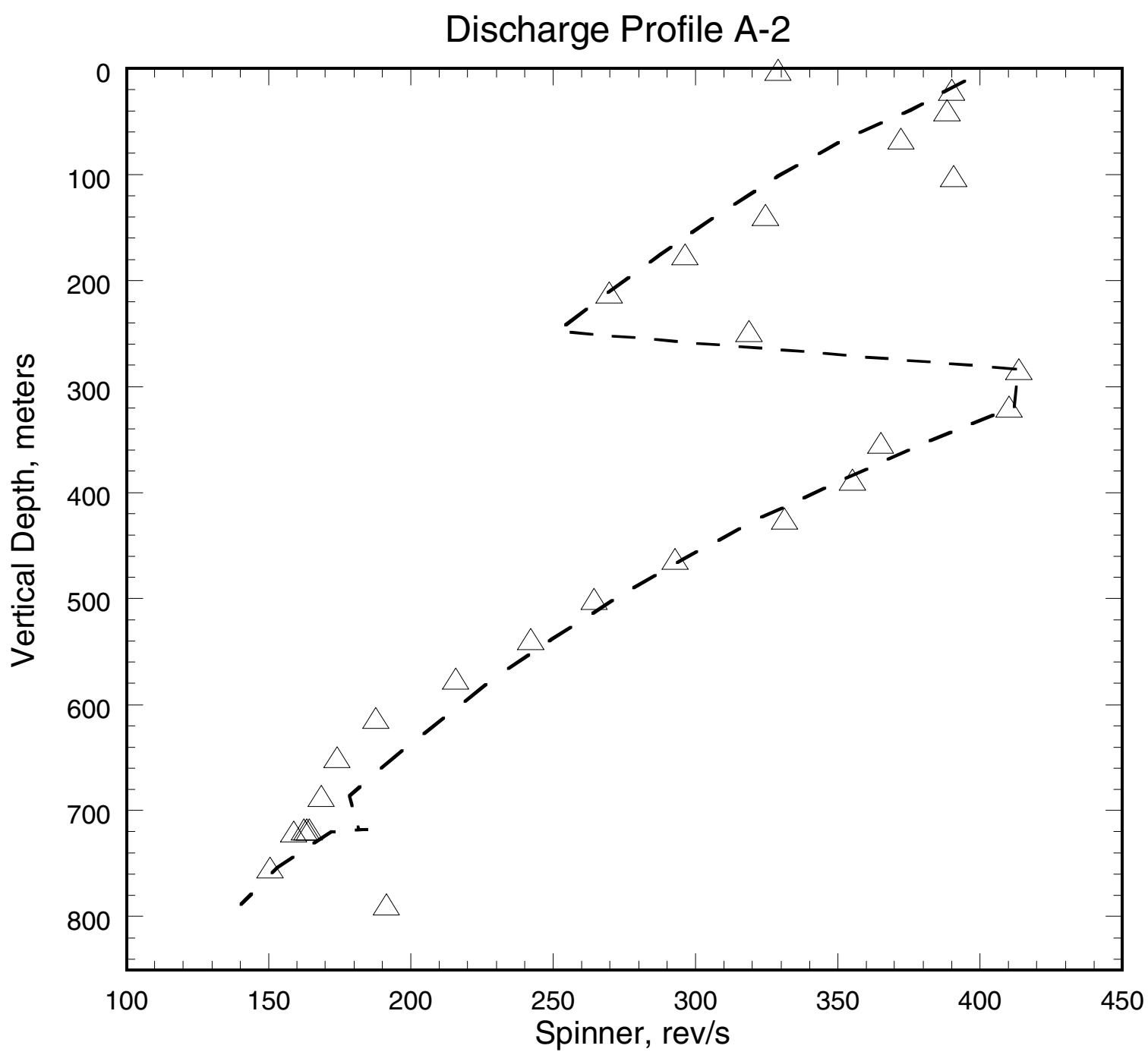

Figure D.2. Comparison of the smoothed spinner response (triangles) with the computed spinner response (dashed line) for well A-2. 


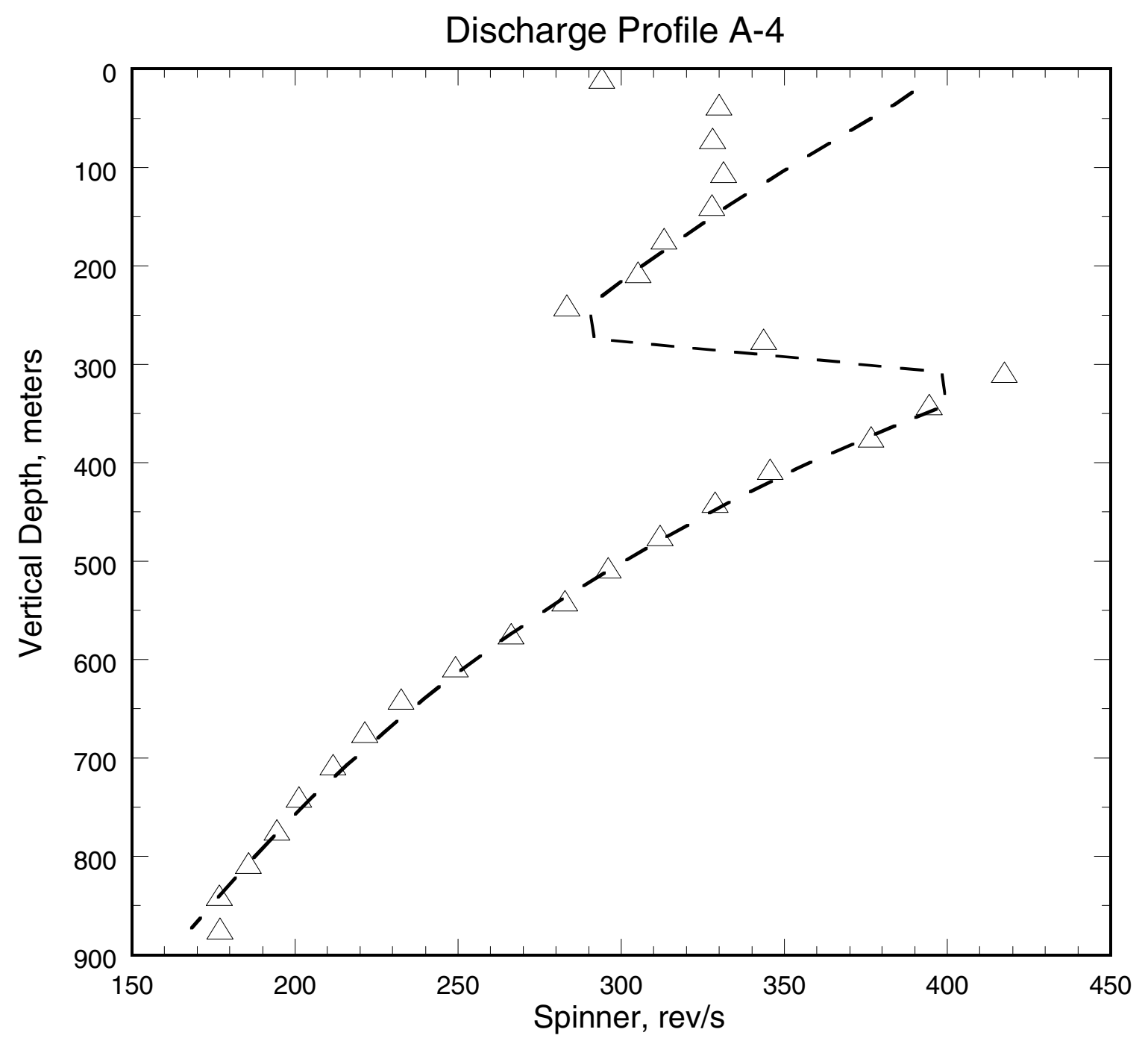

Figure D.3. Comparison of the smoothed spinner response (triangles) with the computed spinner response (dashed line) for well A-4. 


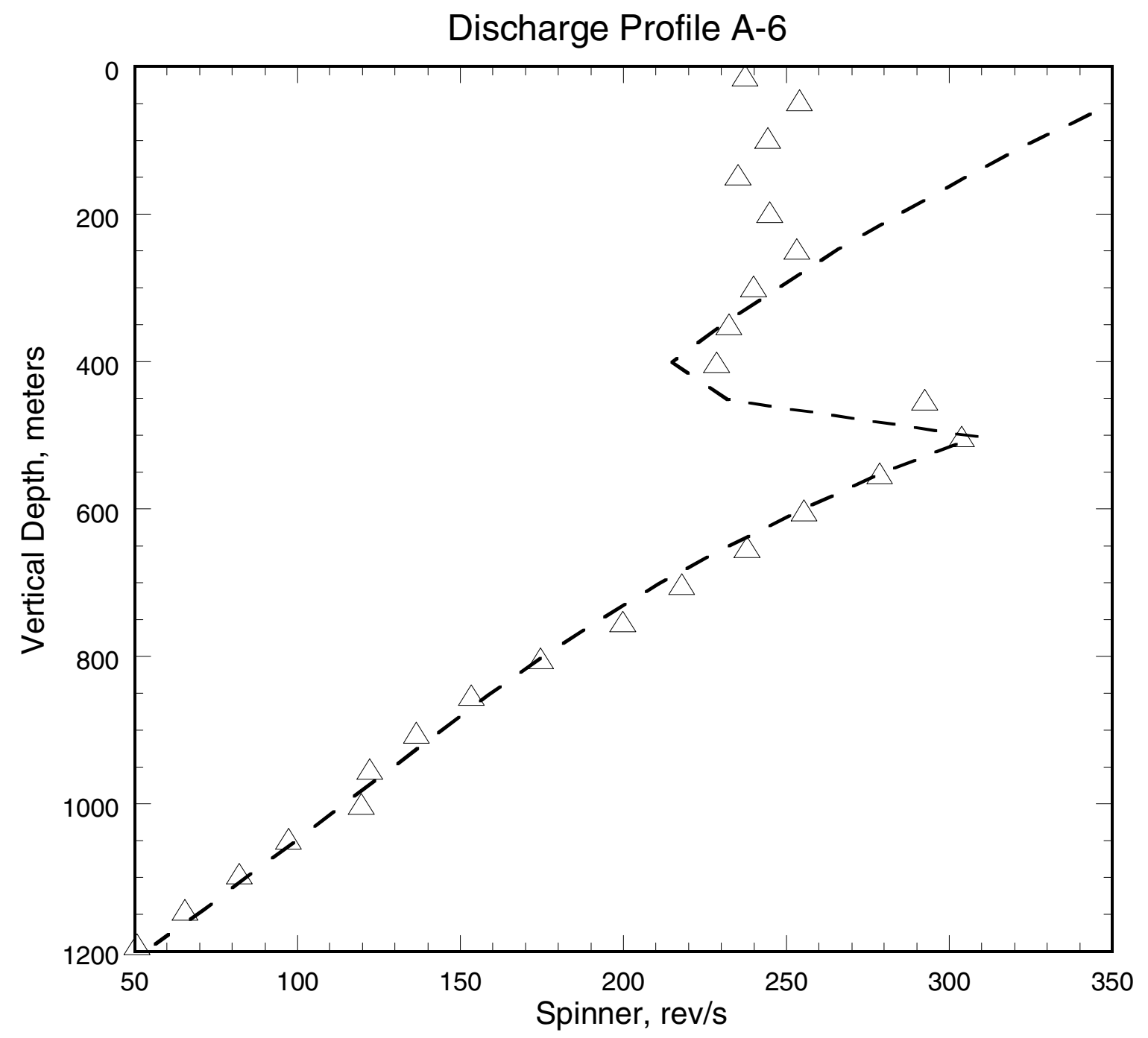

Figure D.4. Comparison of the smoothed spinner response (triangles) with the computed spinner response (dashed line) for well A-6. 


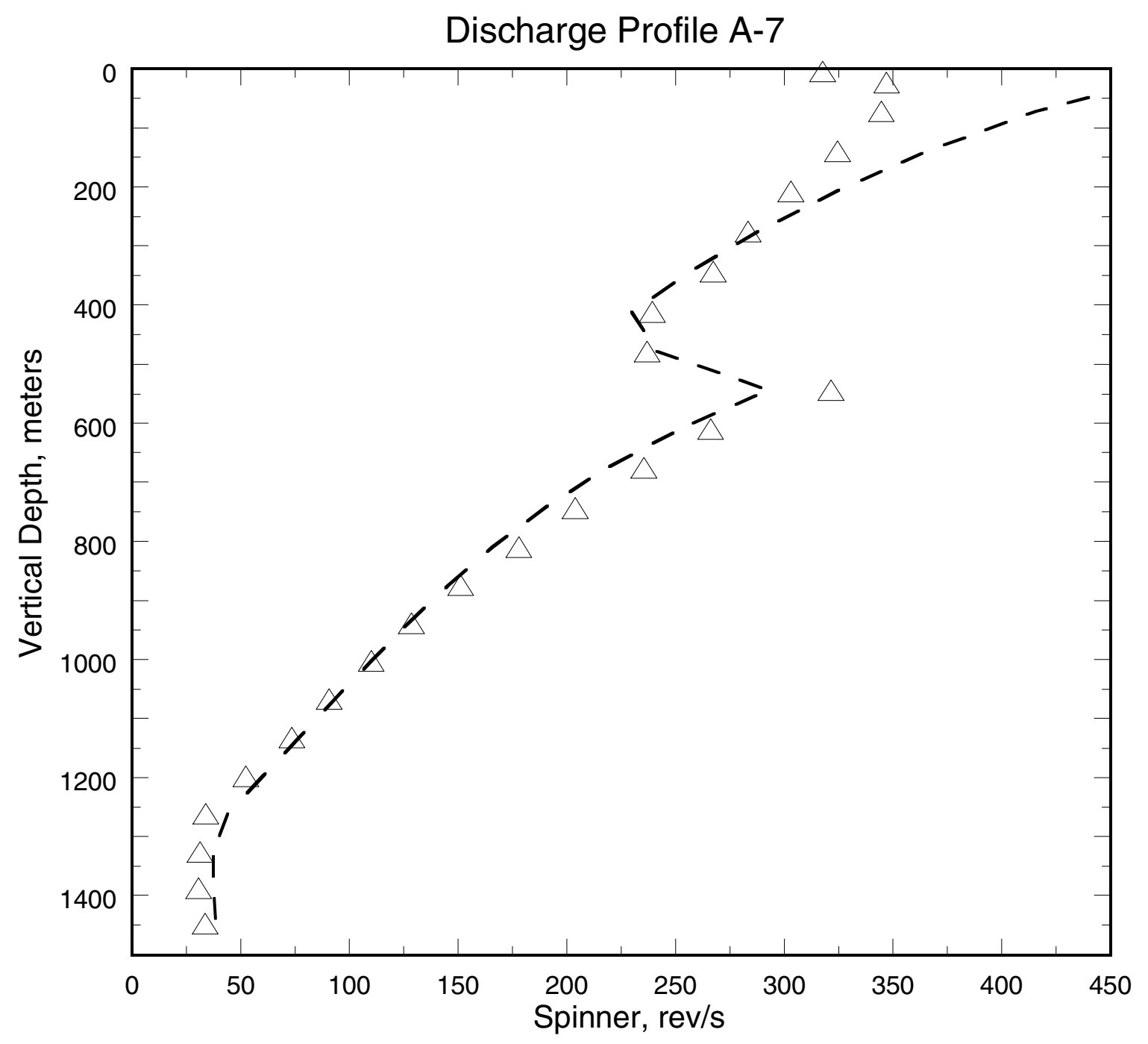

Figure D.5. Comparison of the smoothed spinner response (triangles) with the computed spinner response (dashed line) for well A-7. 


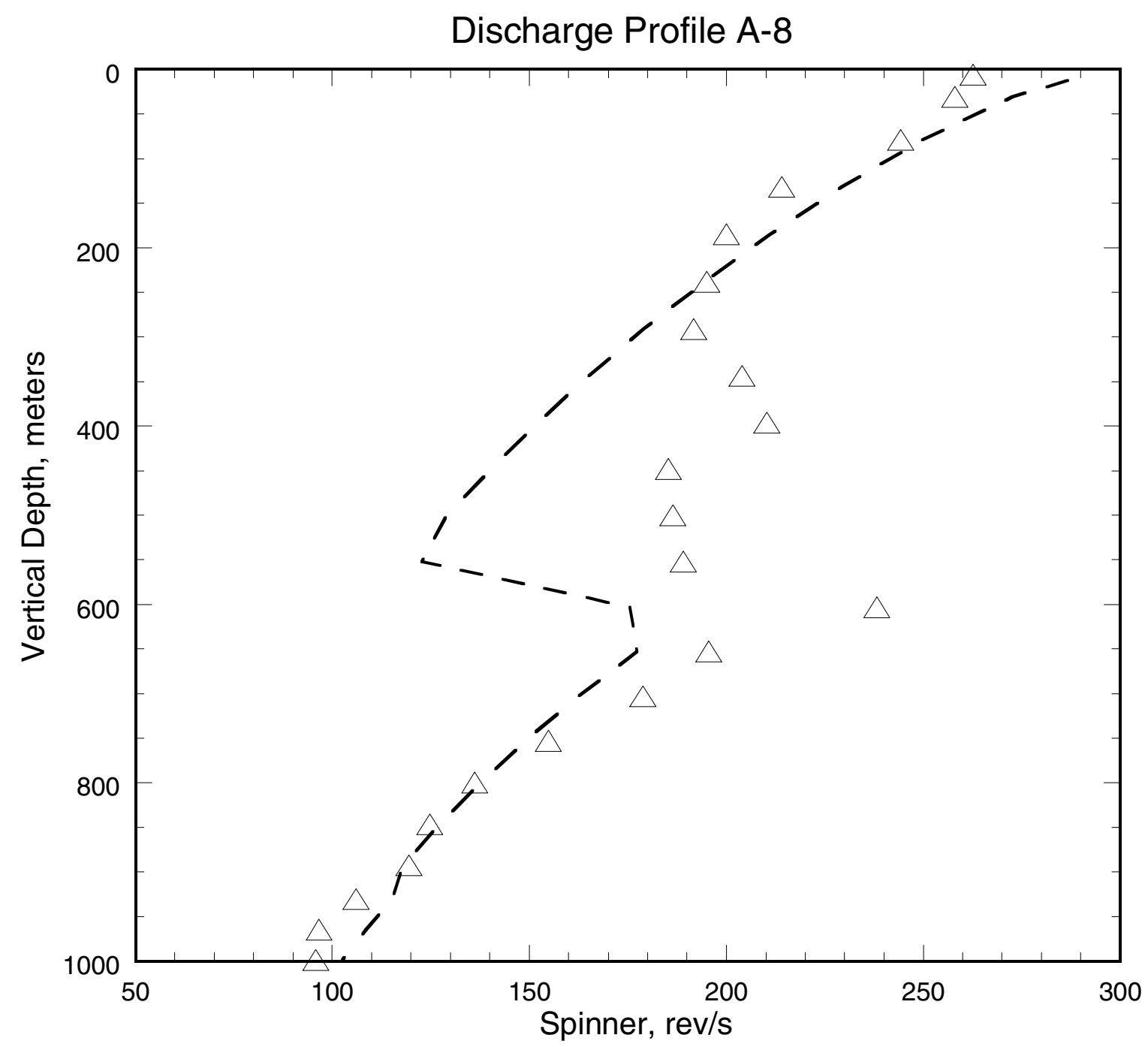

Figure D.6. Comparison of the smoothed spinner response (triangles) with the computed spinner response (dashed line) for well A-8. 


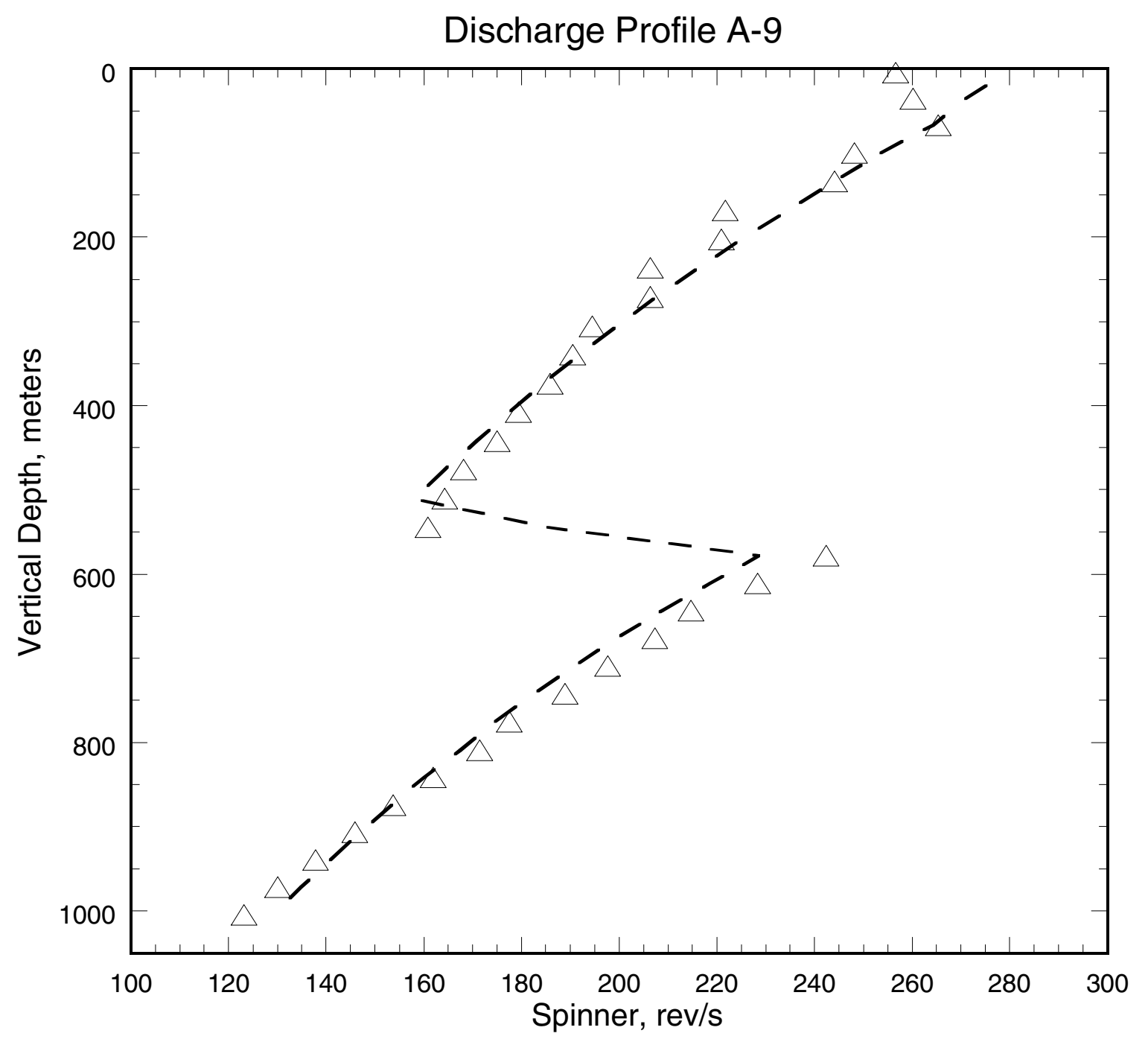

Figure D.7. Comparison of the smoothed spinner response (triangles) with the computed spinner response (dashed line) for well A-9. 


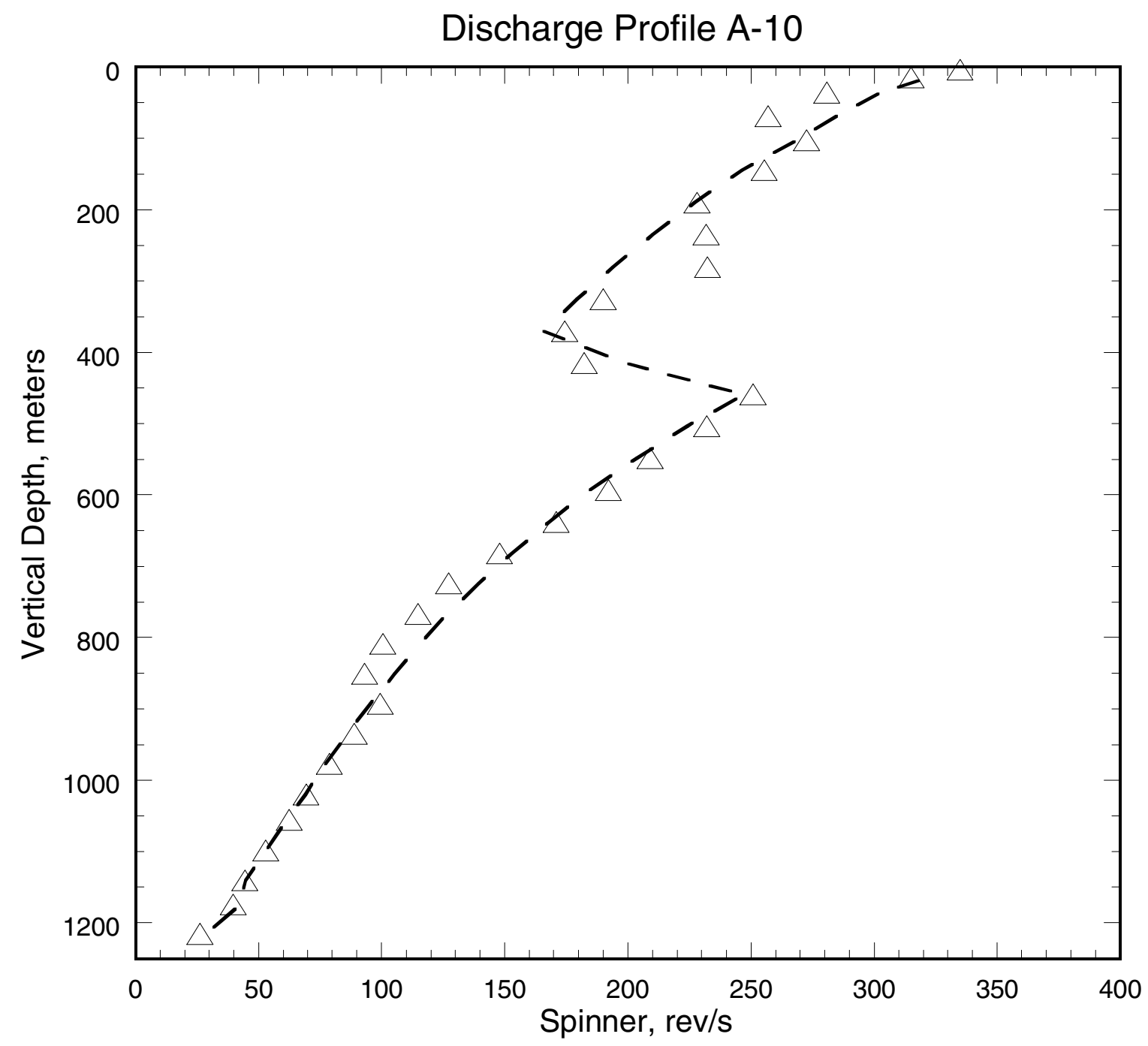

Figure D.8. Comparison of the smoothed spinner response (triangles) with the computed spinner response (dashed line) for well A-10. 


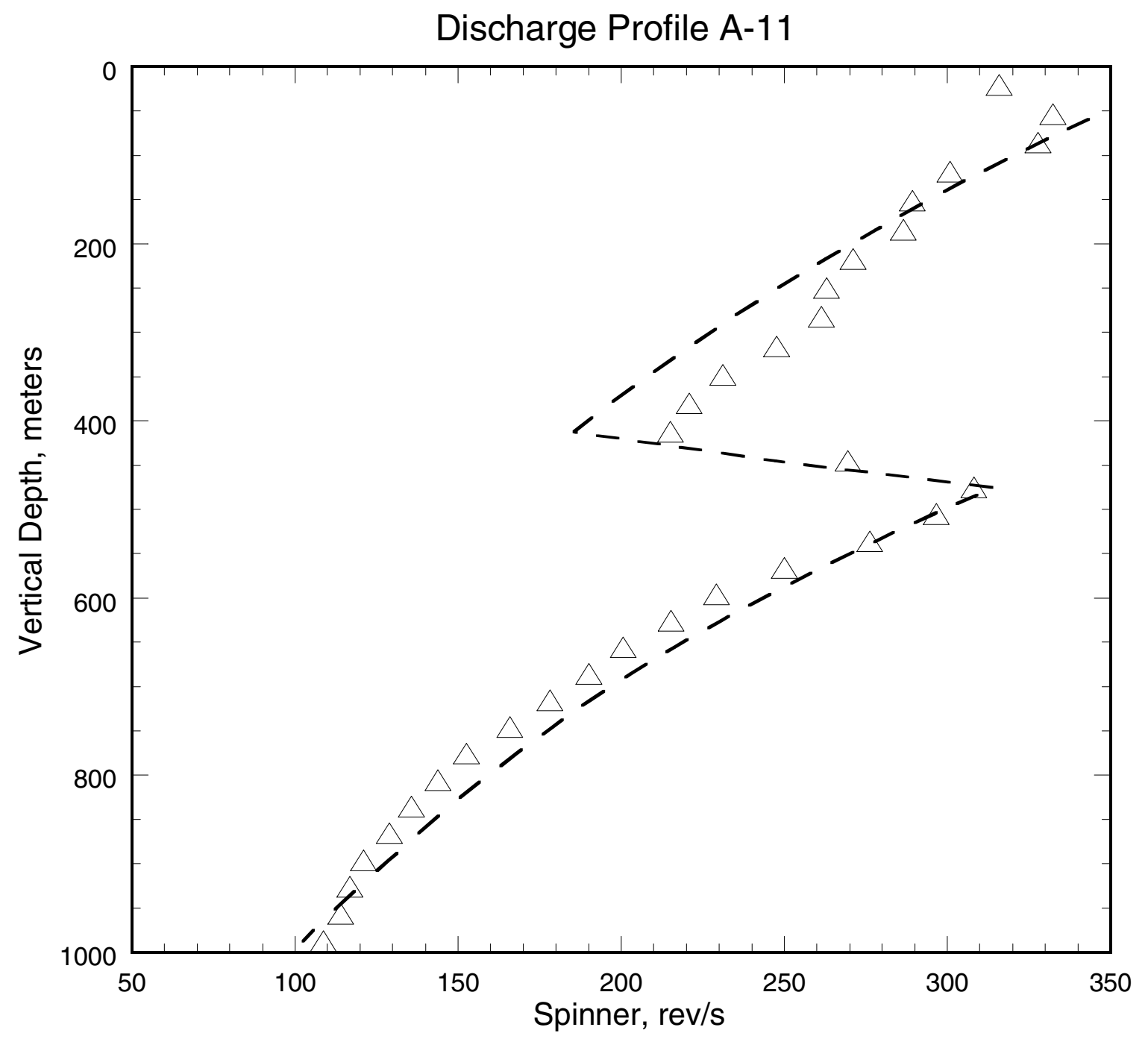

Figure D.9. Comparison of the smoothed spinner response (triangles) with the computed spinner response (dashed line) for well A-11. 


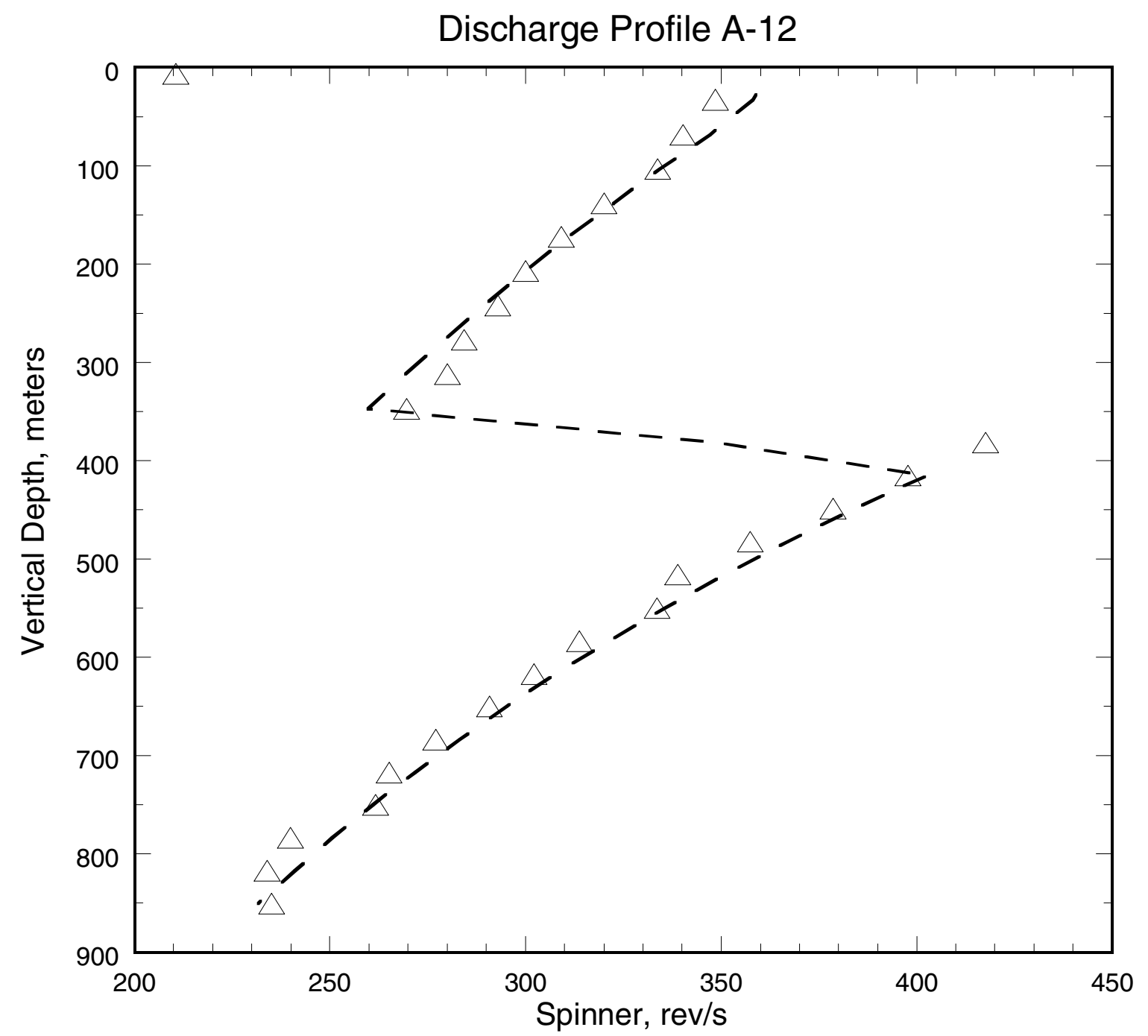

Figure D.10. Comparison of the smoothed spinner response (triangles) with the computed spinner response (dashed line) for well A-12. 


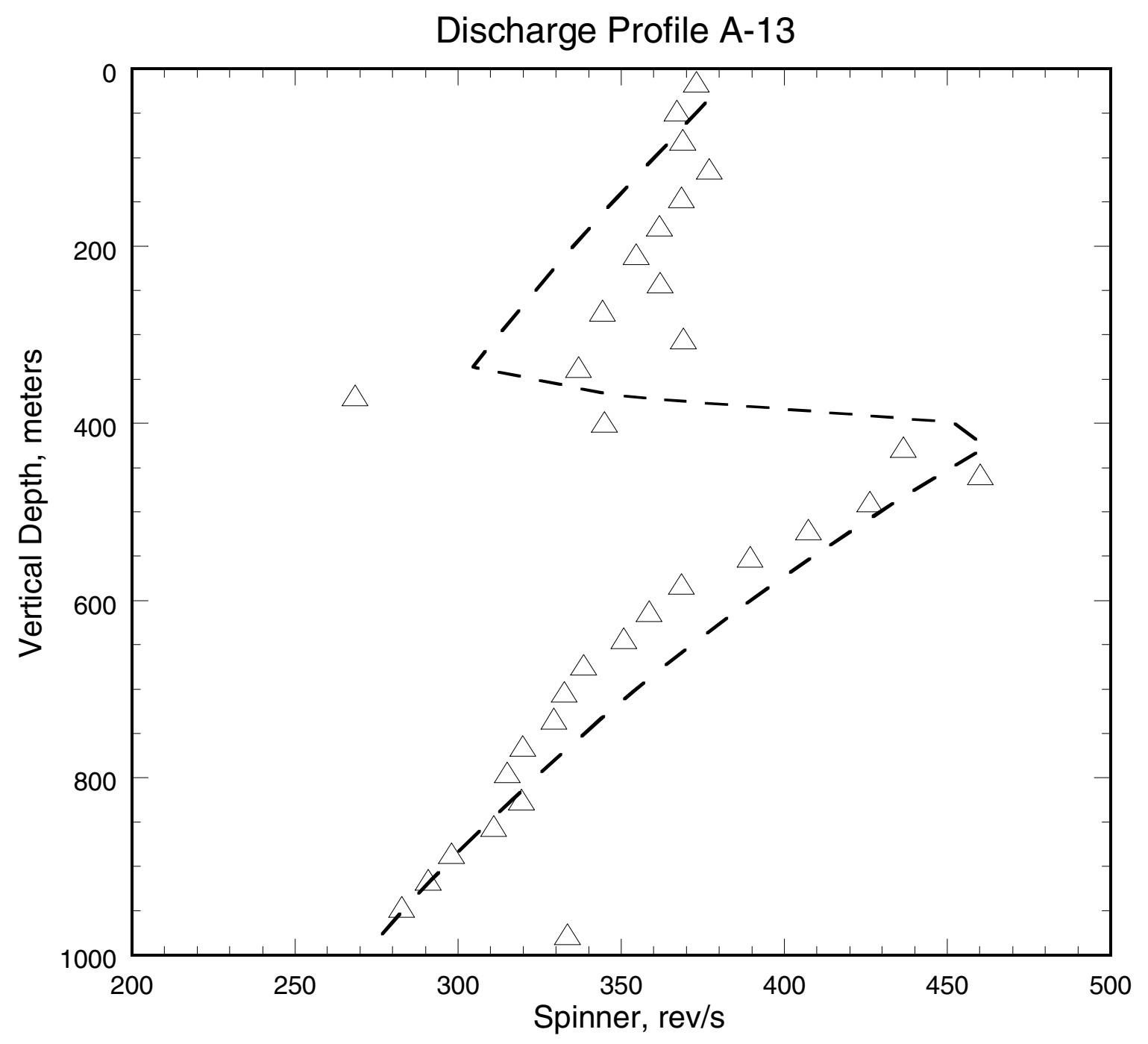

Figure D.11. Comparison of the smoothed spinner response (triangles) with the computed spinner response (dashed line) for well A-13. 


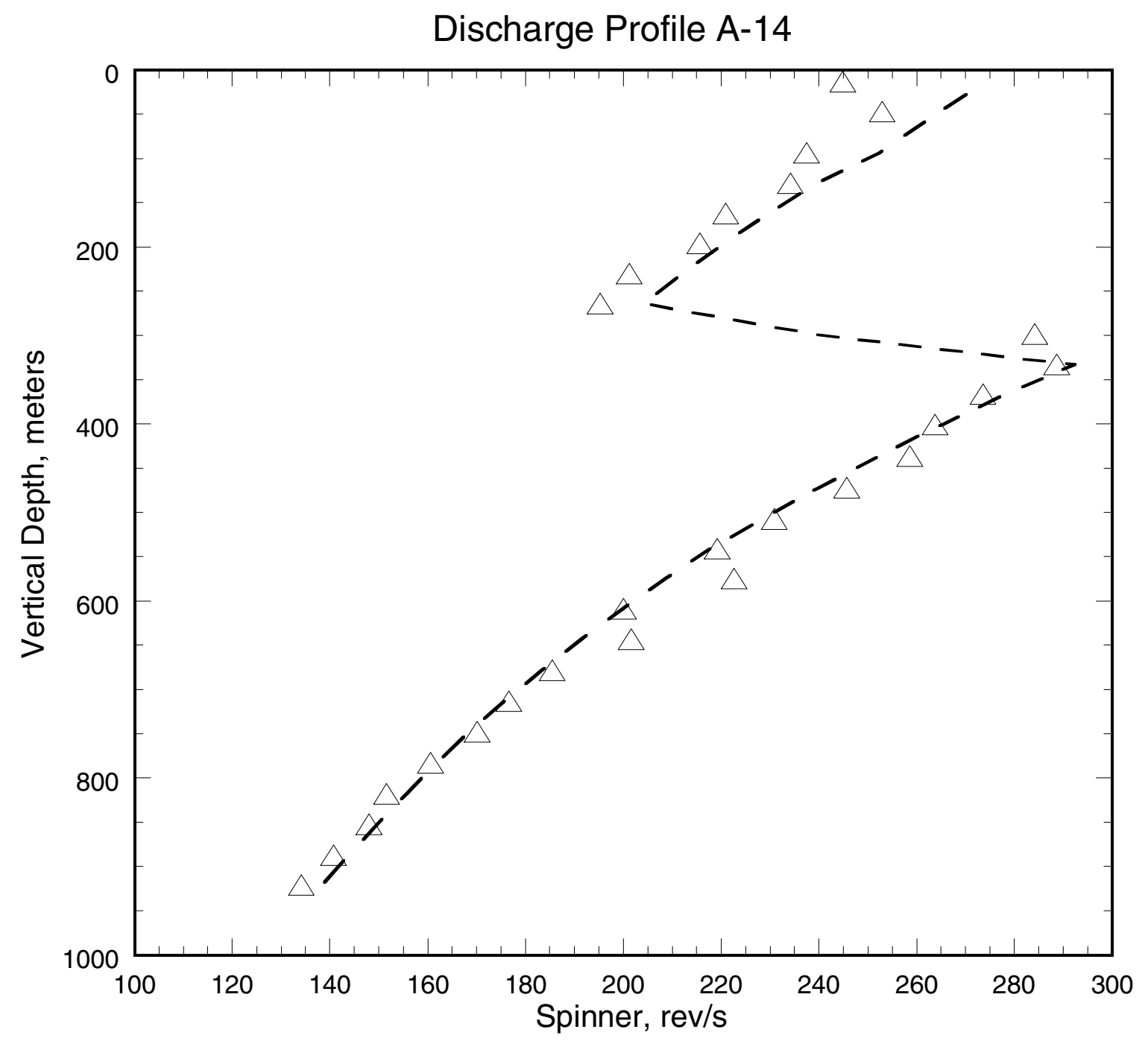

Figure D.12. Comparison of the smoothed spinner response (triangles) with the computed spinner response (dashed line) for well A-14. 


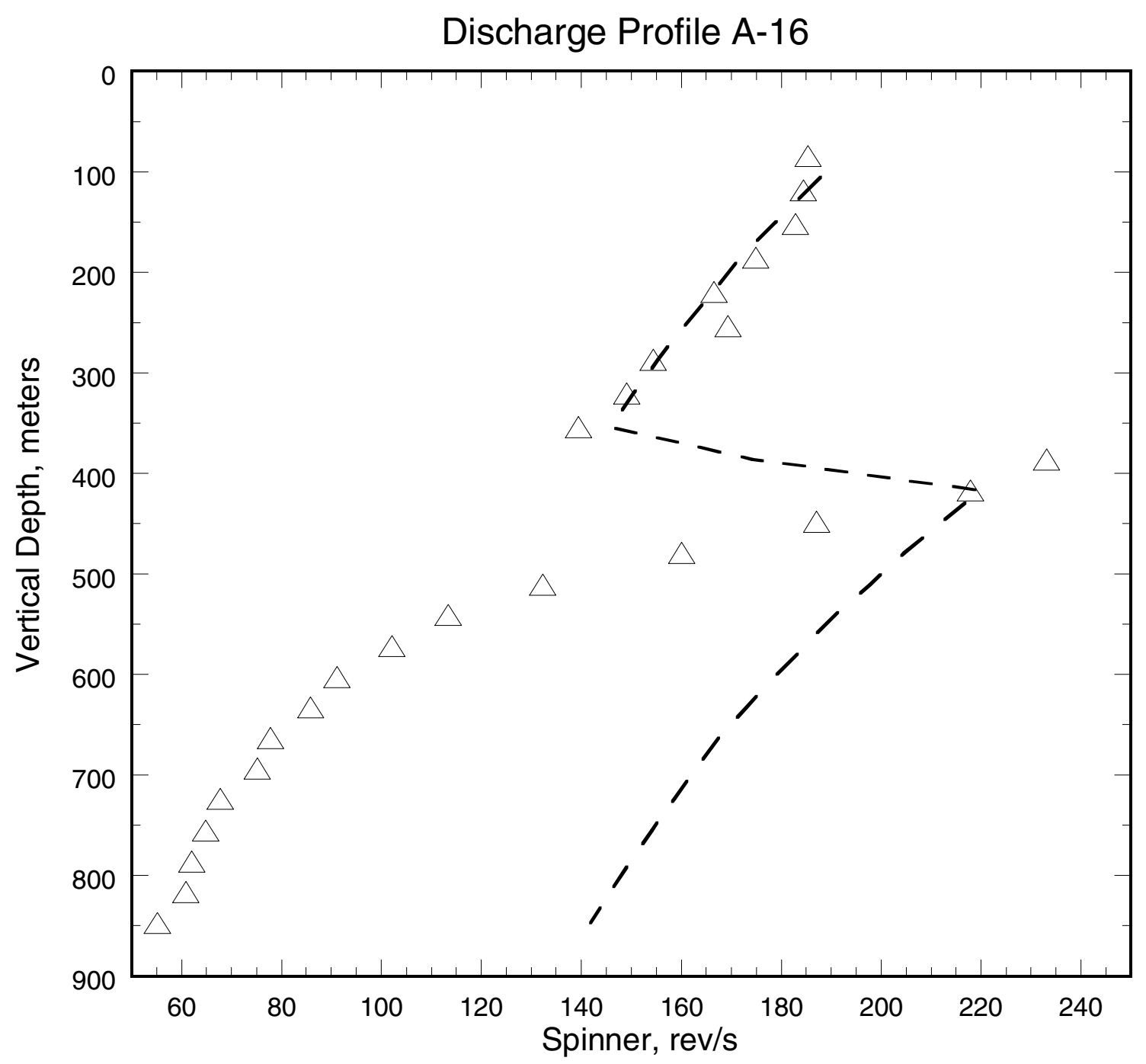

Figure D.13. Comparison of the smoothed spinner response (triangles) with the computed spinner response (dashed line) for well A-16. 


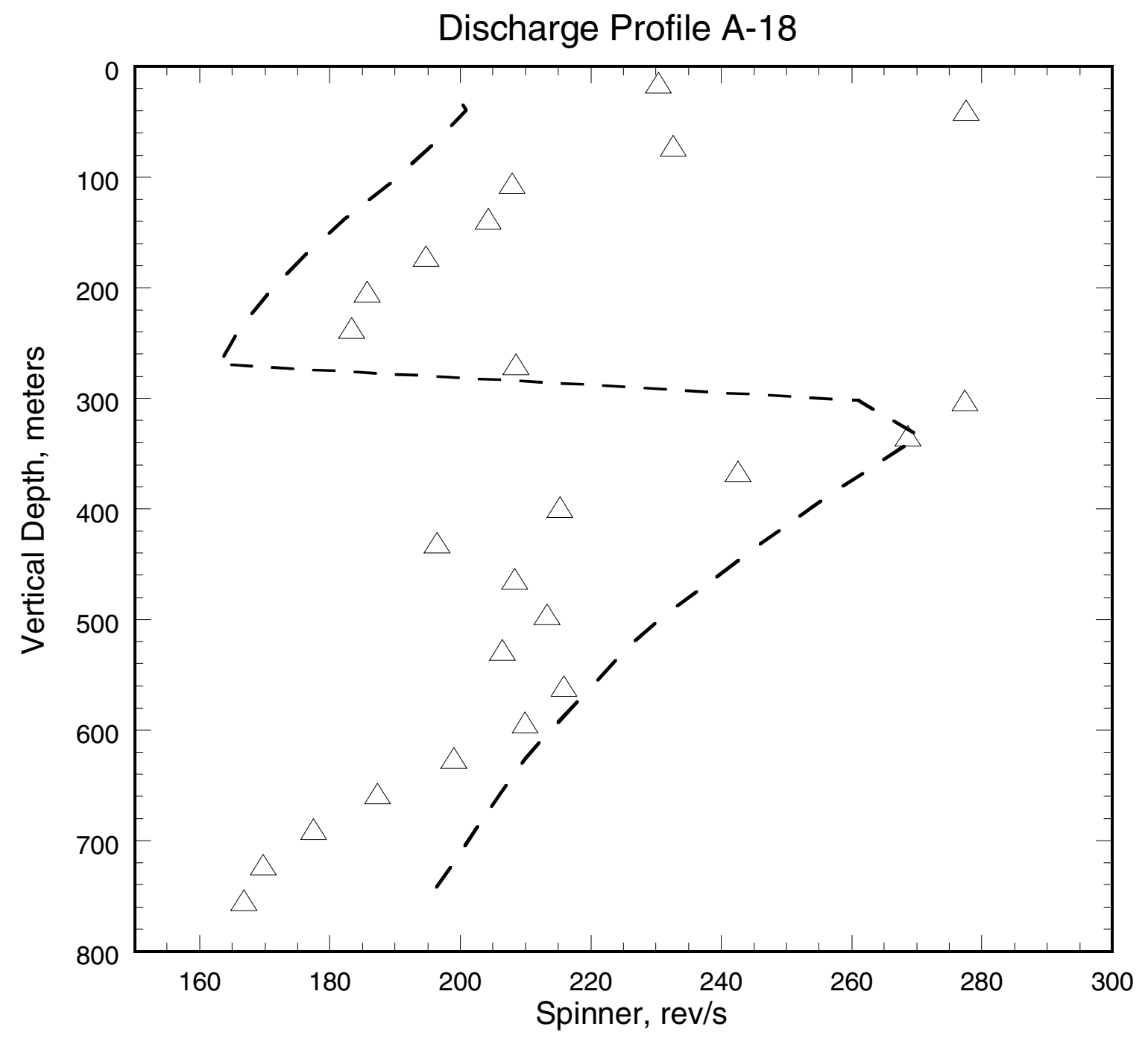

Figure D.14. Comparison of the smoothed spinner response (triangles) with the computed spinner response (dashed line) for well A-18. 


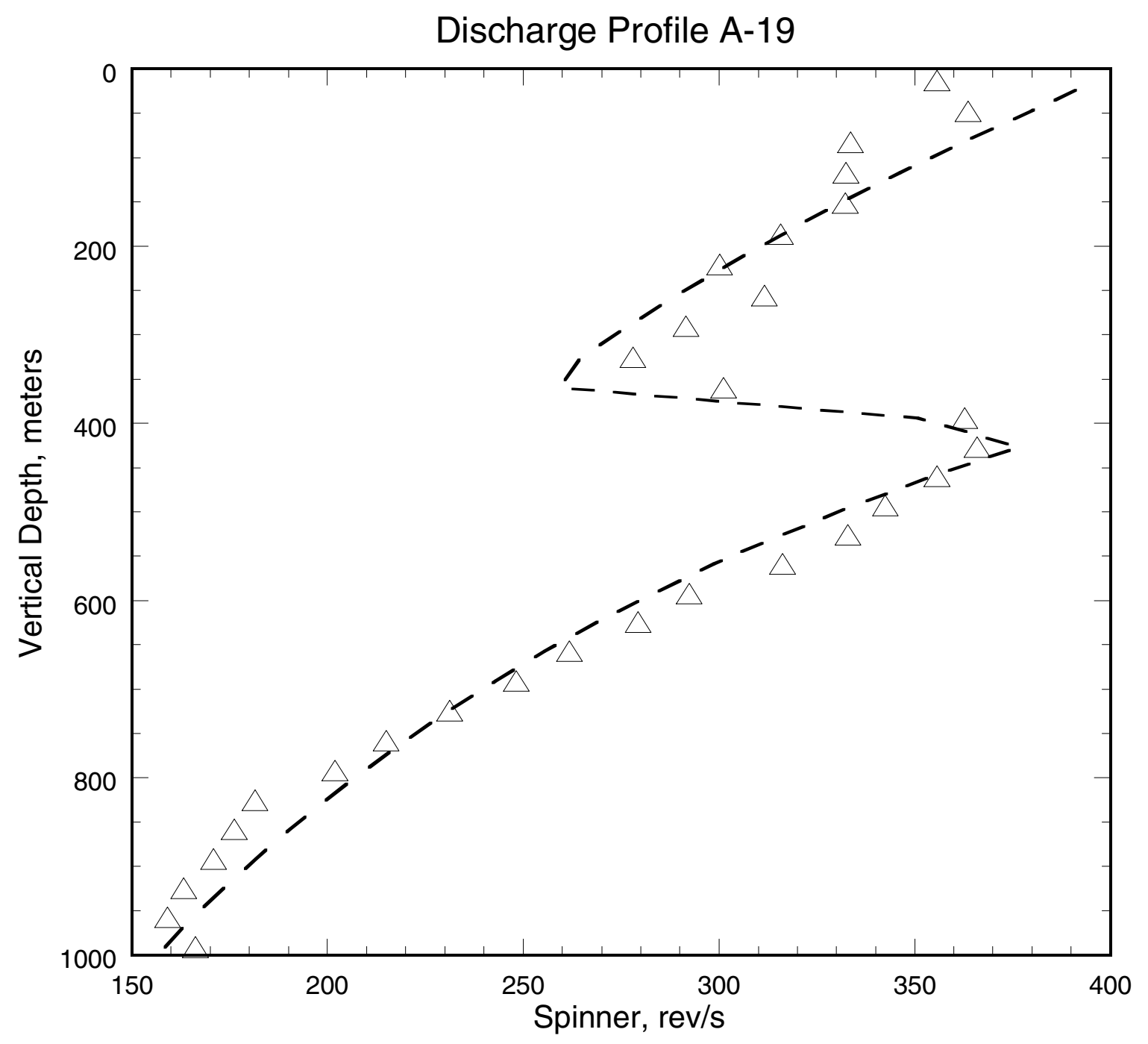

Figure D.15. Comparison of the smoothed spinner response (triangles) with the computed spinner response (dashed line) for well A-19. 


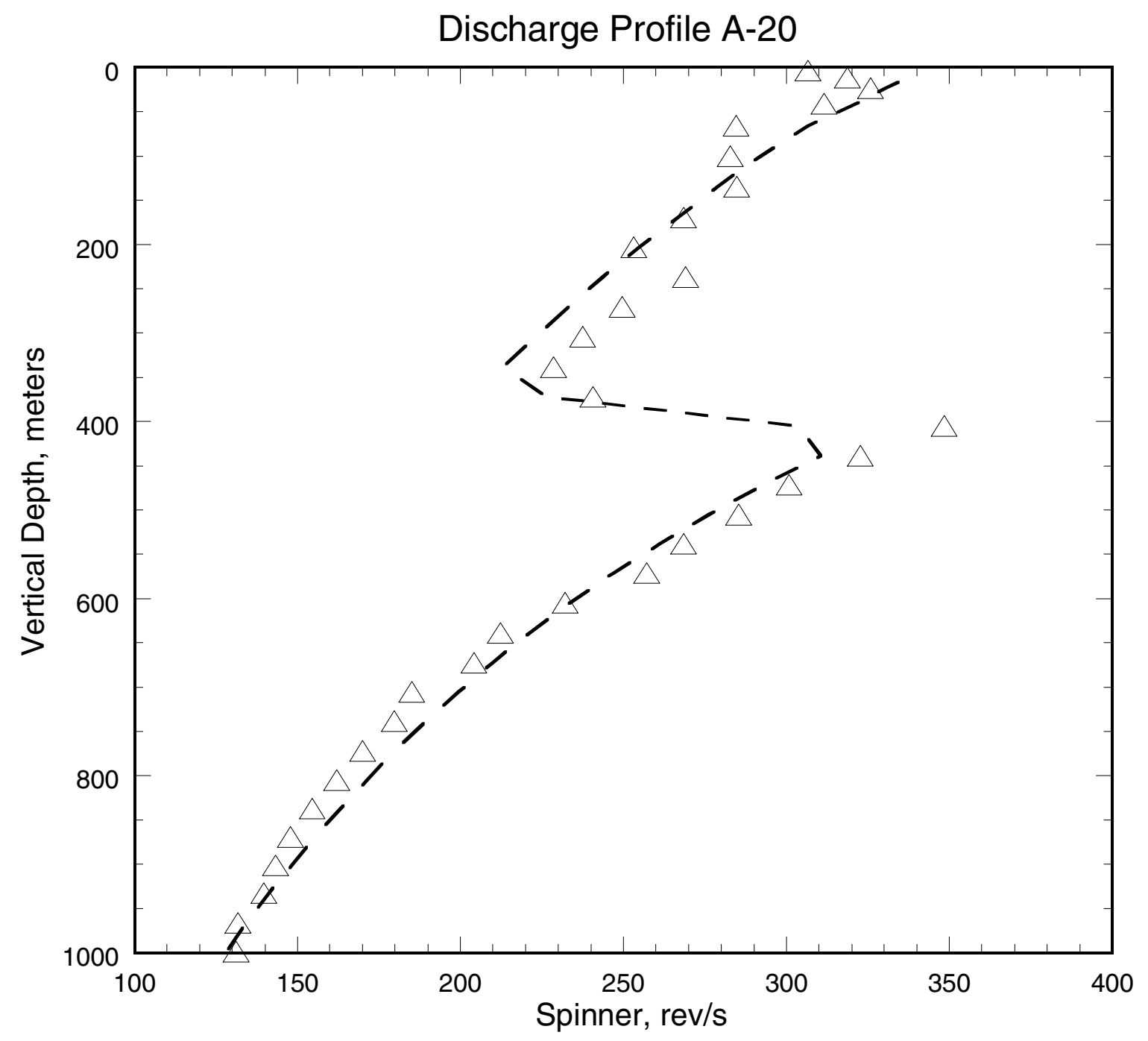

Figure D.16. Comparison of the smoothed spinner response (triangles) with the computed spinner response (dashed line) for well A-20. 


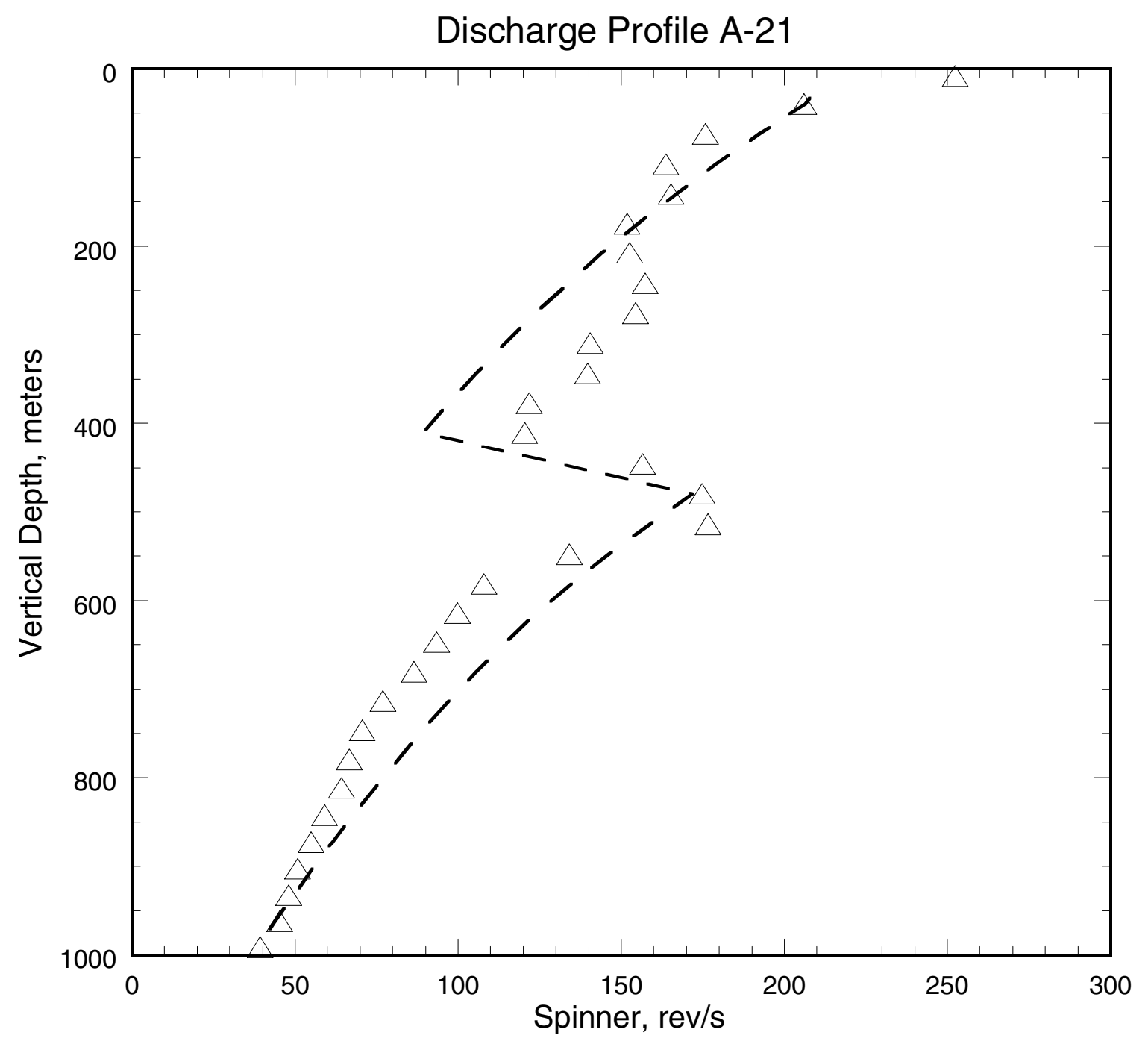

Figure D.17. Comparison of the smoothed spinner response (triangles) with the computed spinner response (dashed line) for well A-21. 
Discharge Profile B-3

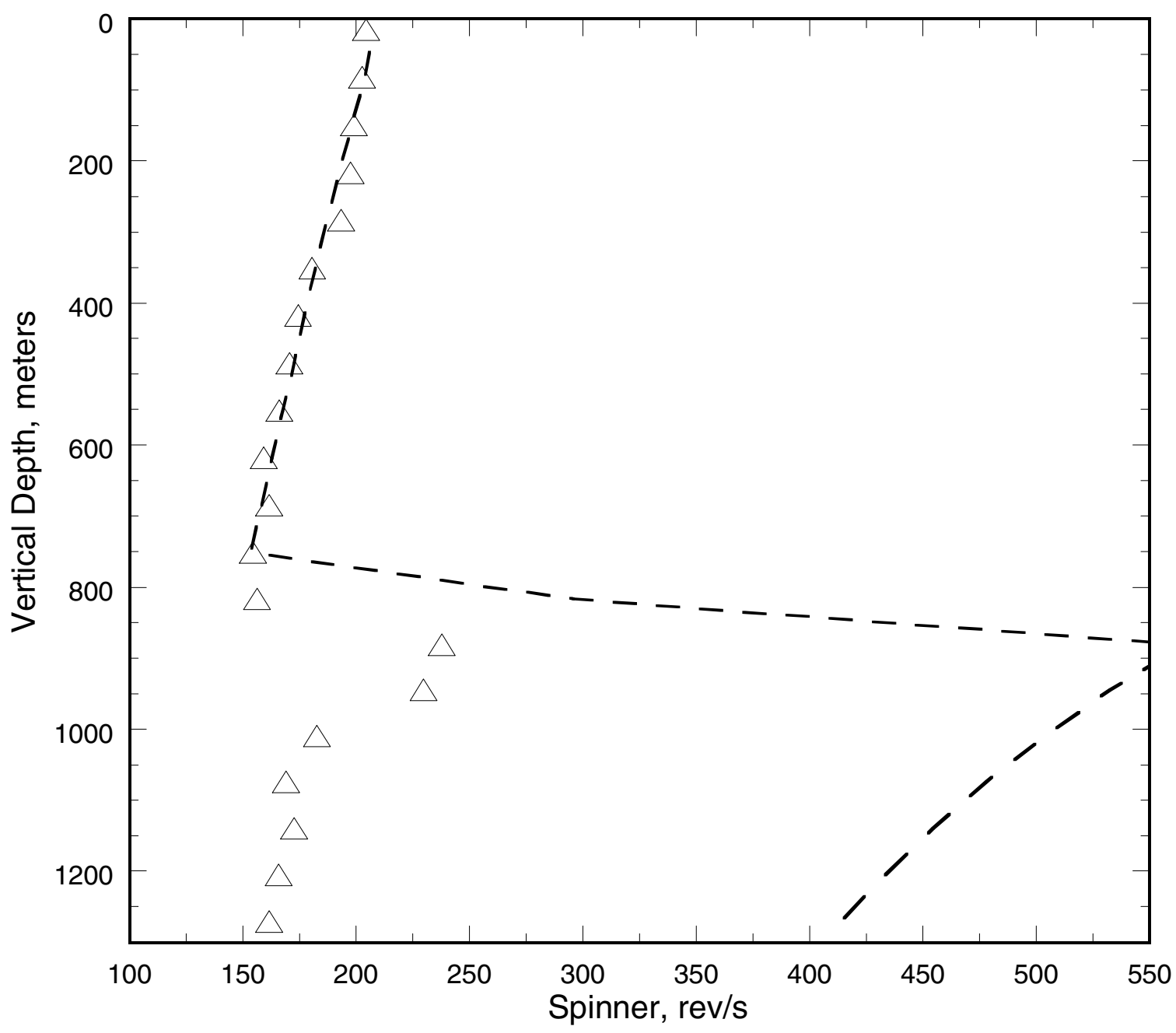

Figure D.18. Comparison of the smoothed spinner response (triangles) with the computed spinner response (dashed line) for well B-3. 


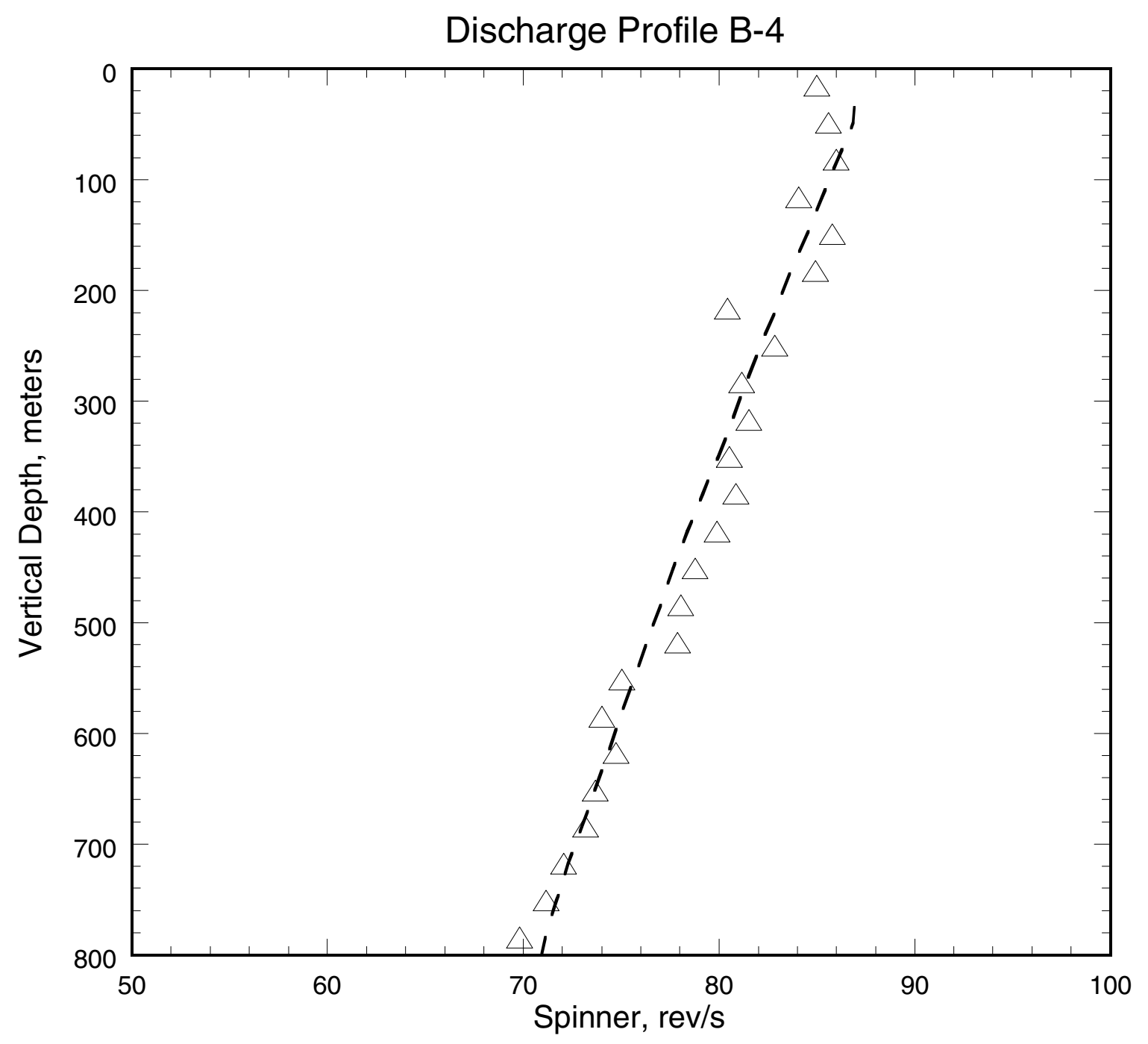

Figure D.19. Comparison of the smoothed spinner response (triangles) with the computed spinner response (dashed line) for well B-4. 


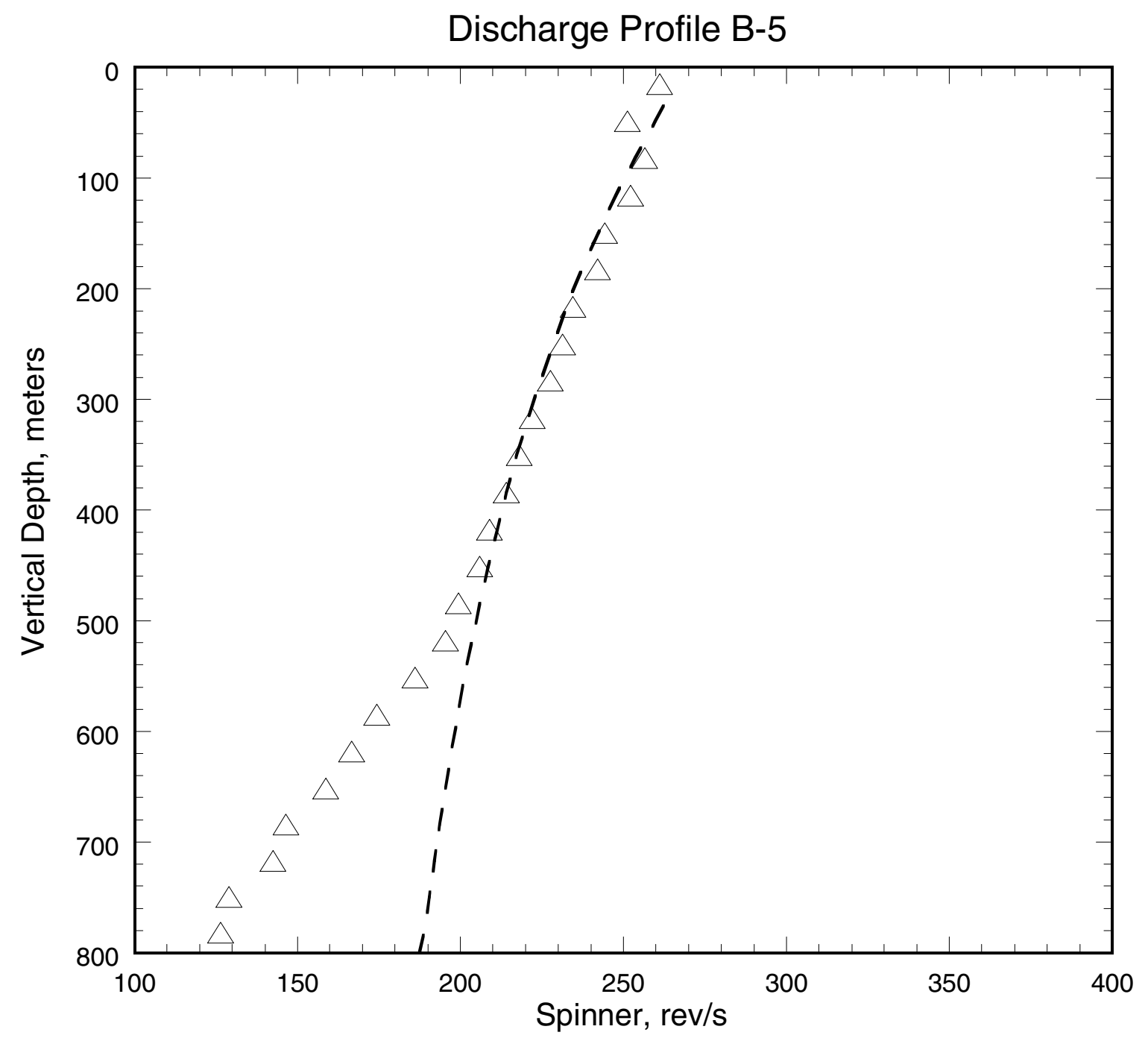

Figure D.20. Comparison of the smoothed spinner response (triangles) with the computed spinner response (dashed line) for well B-5. 


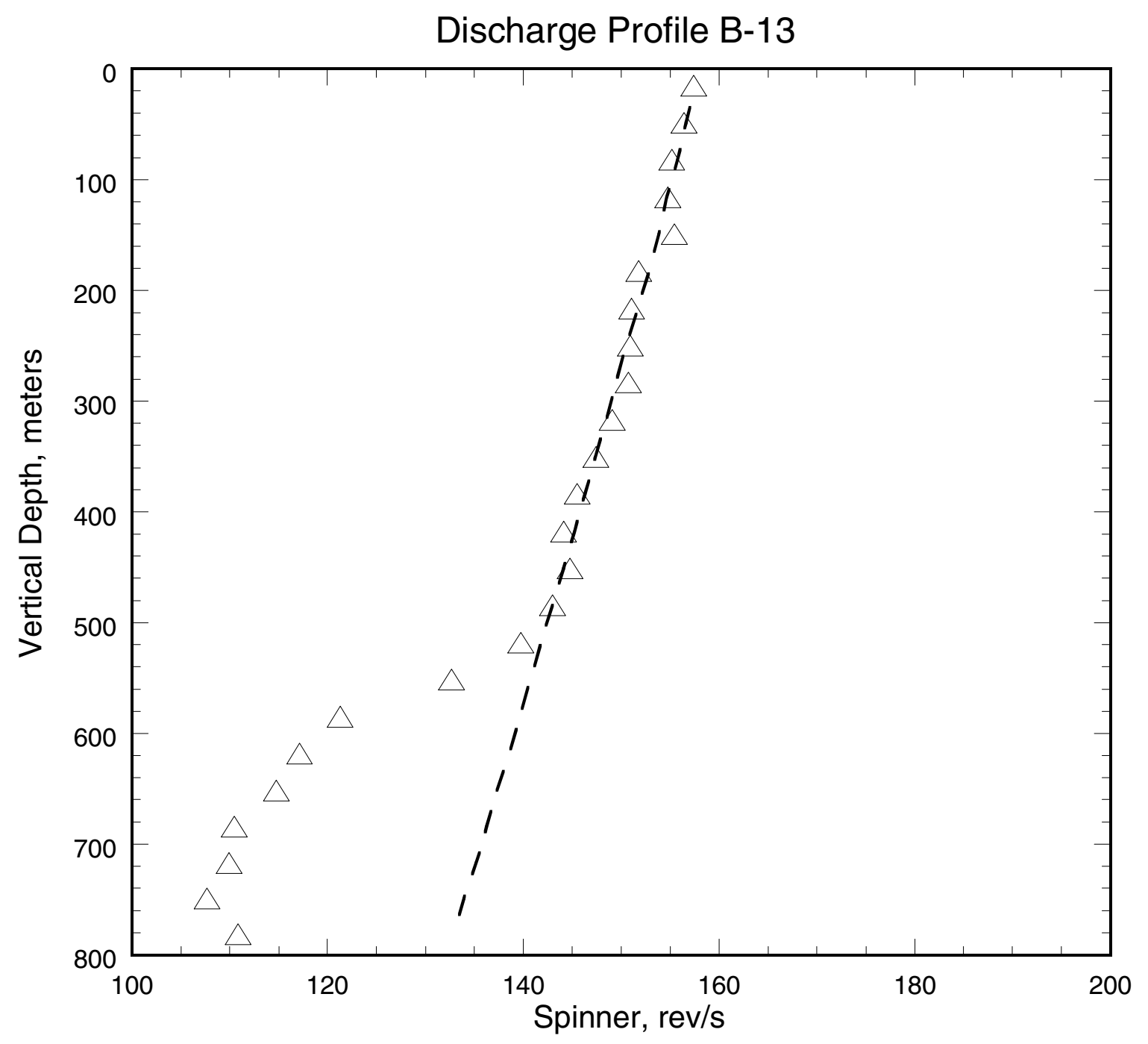

Figure D.21. Comparison of the smoothed spinner response (triangles) with the computed spinner response (dashed line) for well B-13. 


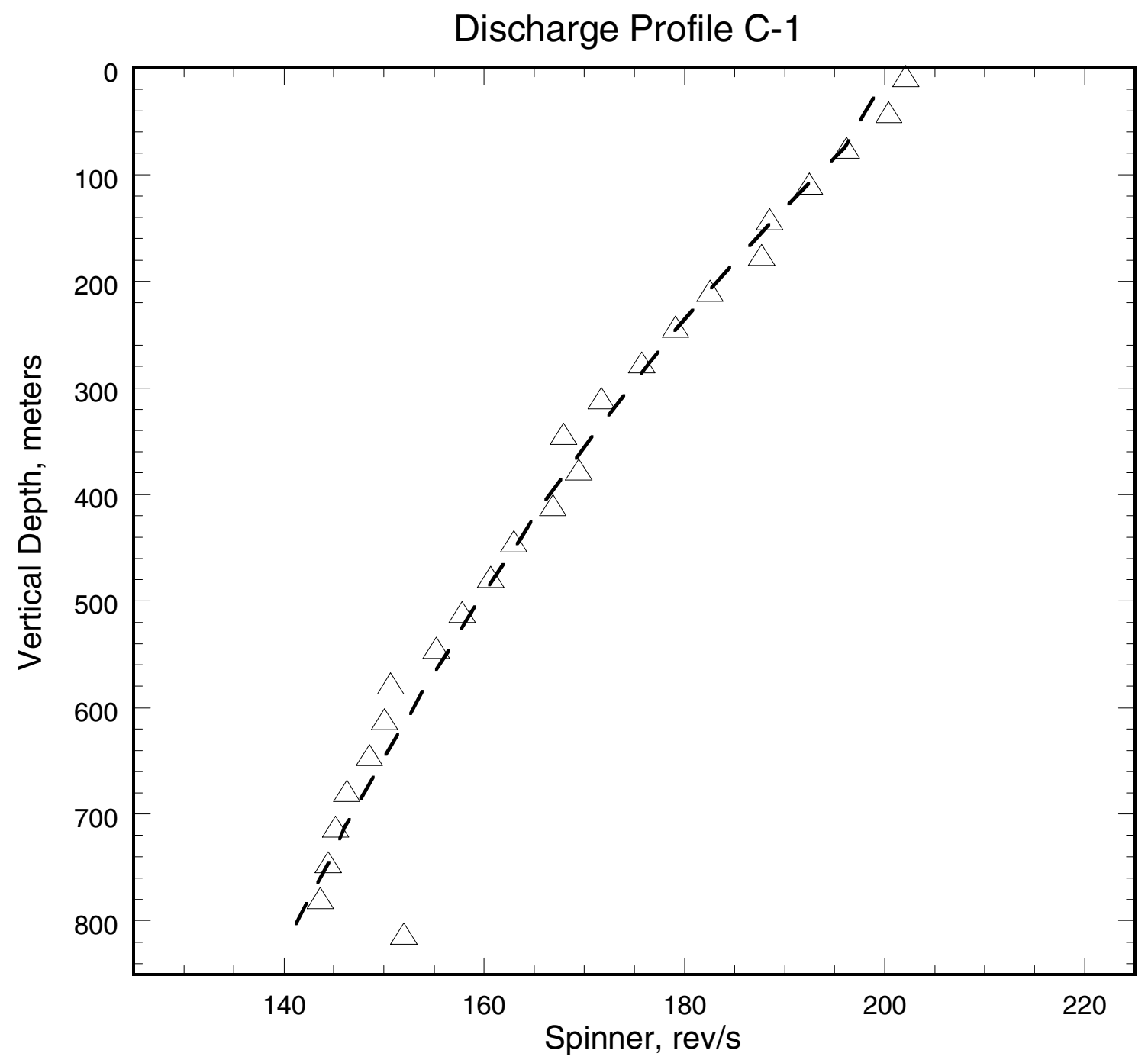

Figure D.22. Comparison of the smoothed spinner response (triangles) with the computed spinner response (dashed line) for well $\mathrm{C}-1$. 


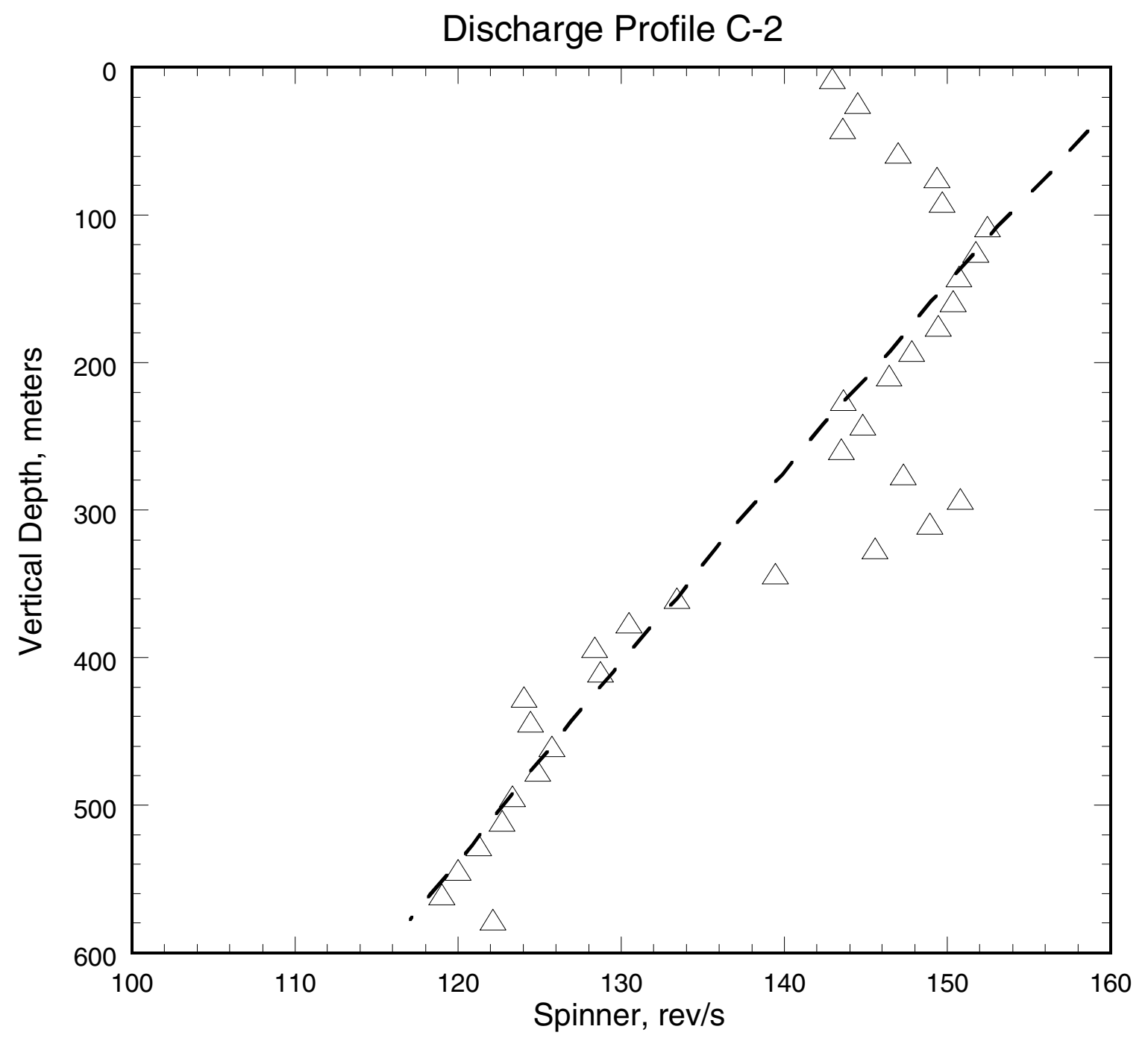

Figure D.23. Comparison of the smoothed spinner response (triangles) with the computed spinner response (dashed line) for well C-2. 


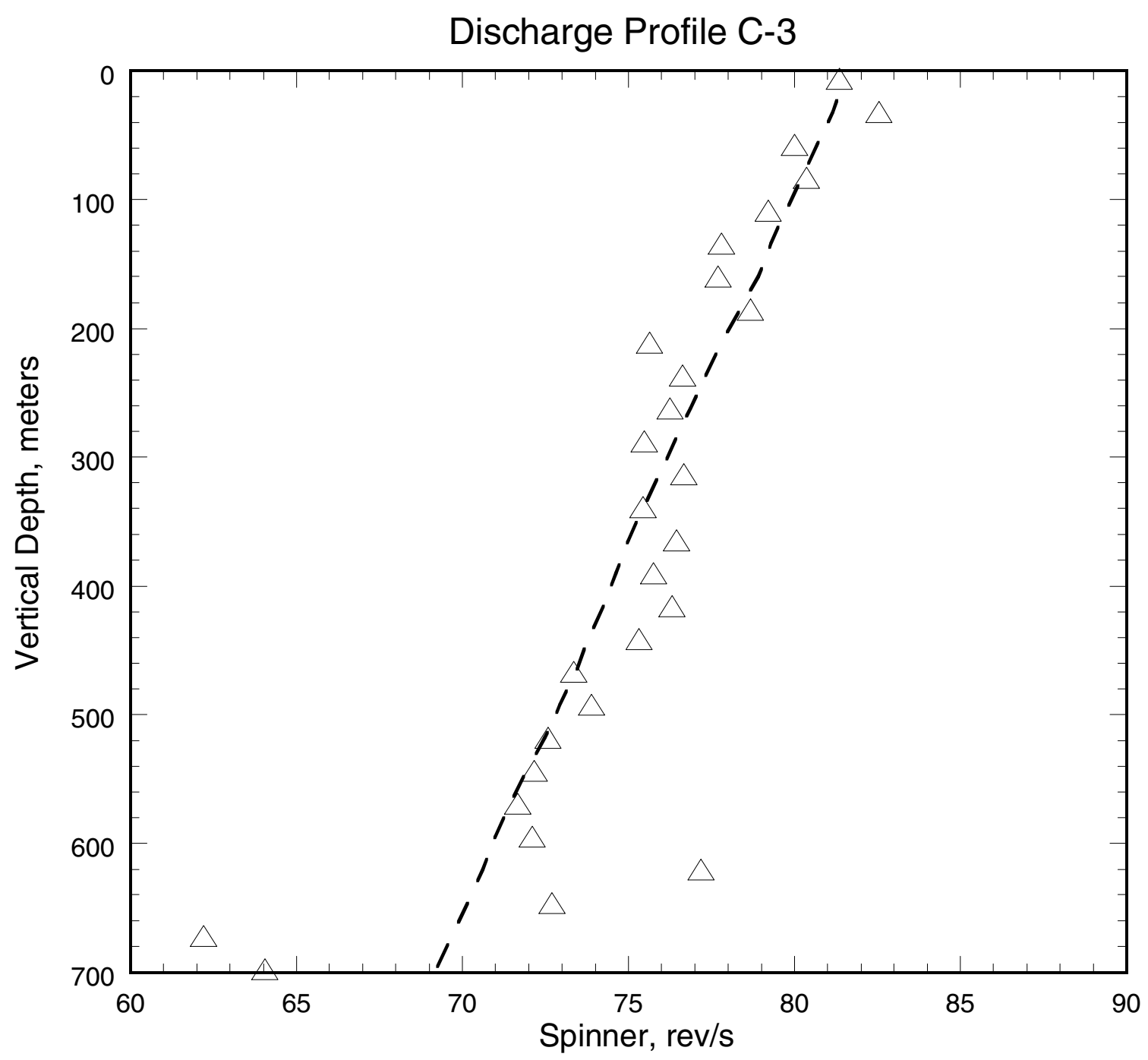

Figure D.24. Comparison of the smoothed spinner response (triangles) with the computed spinner response (dashed line) for well C-3. 


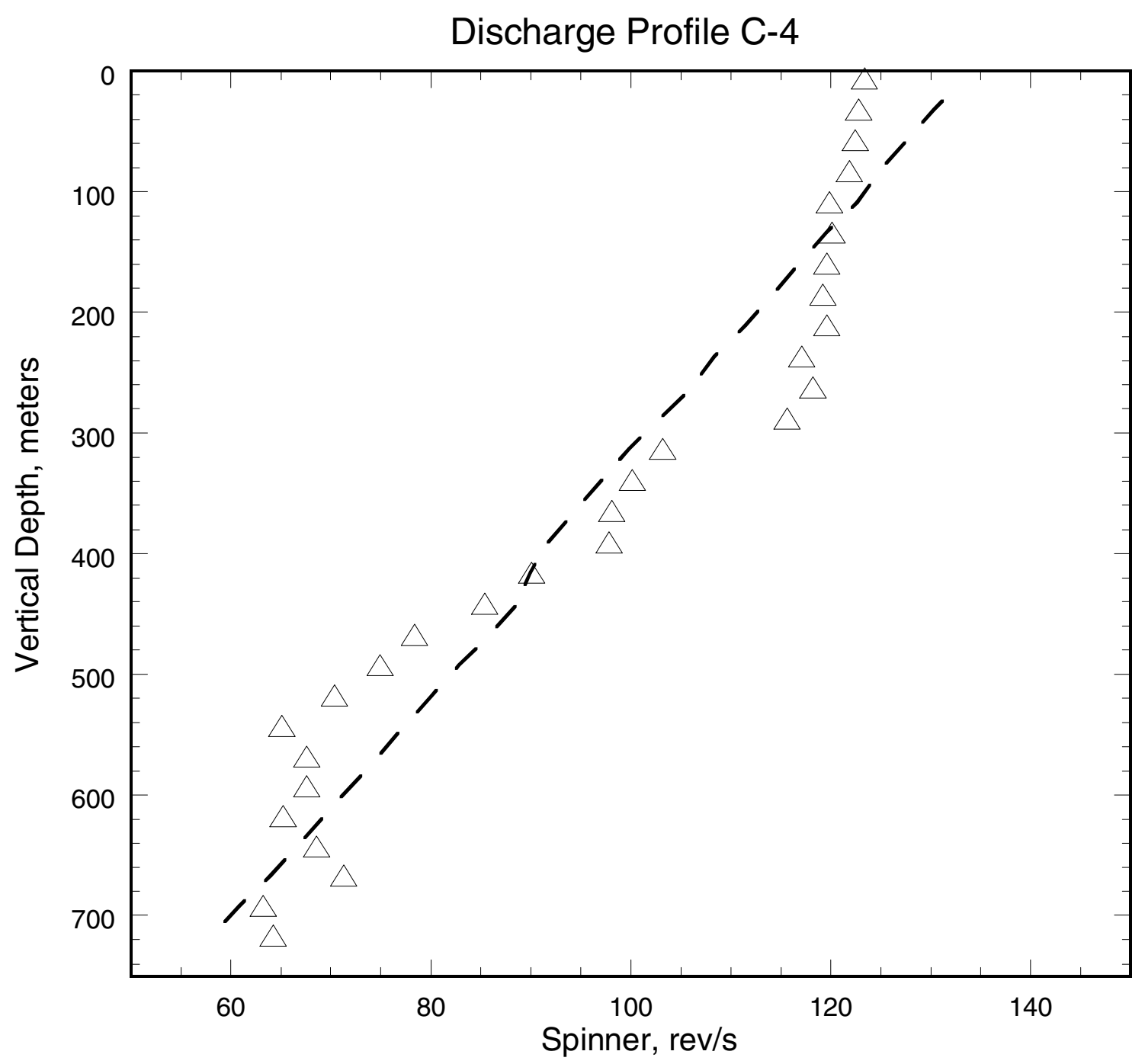

Figure D.25. Comparison of the smoothed spinner response (triangles) with the computed spinner response (dashed line) for well C-4. 


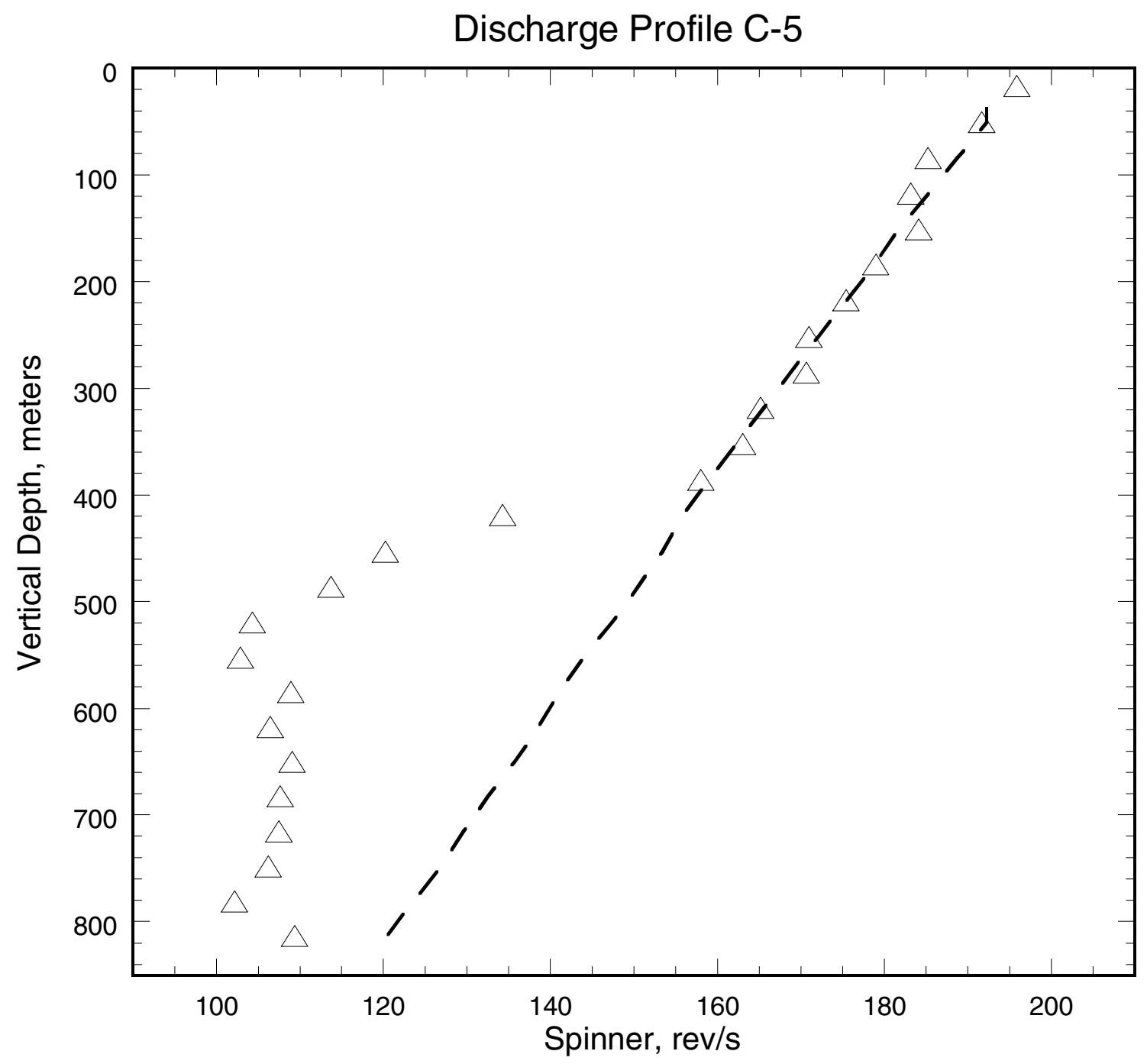

Figure D.26. Comparison of the smoothed spinner response (triangles) with the computed spinner response (dashed line) for well C-5. 


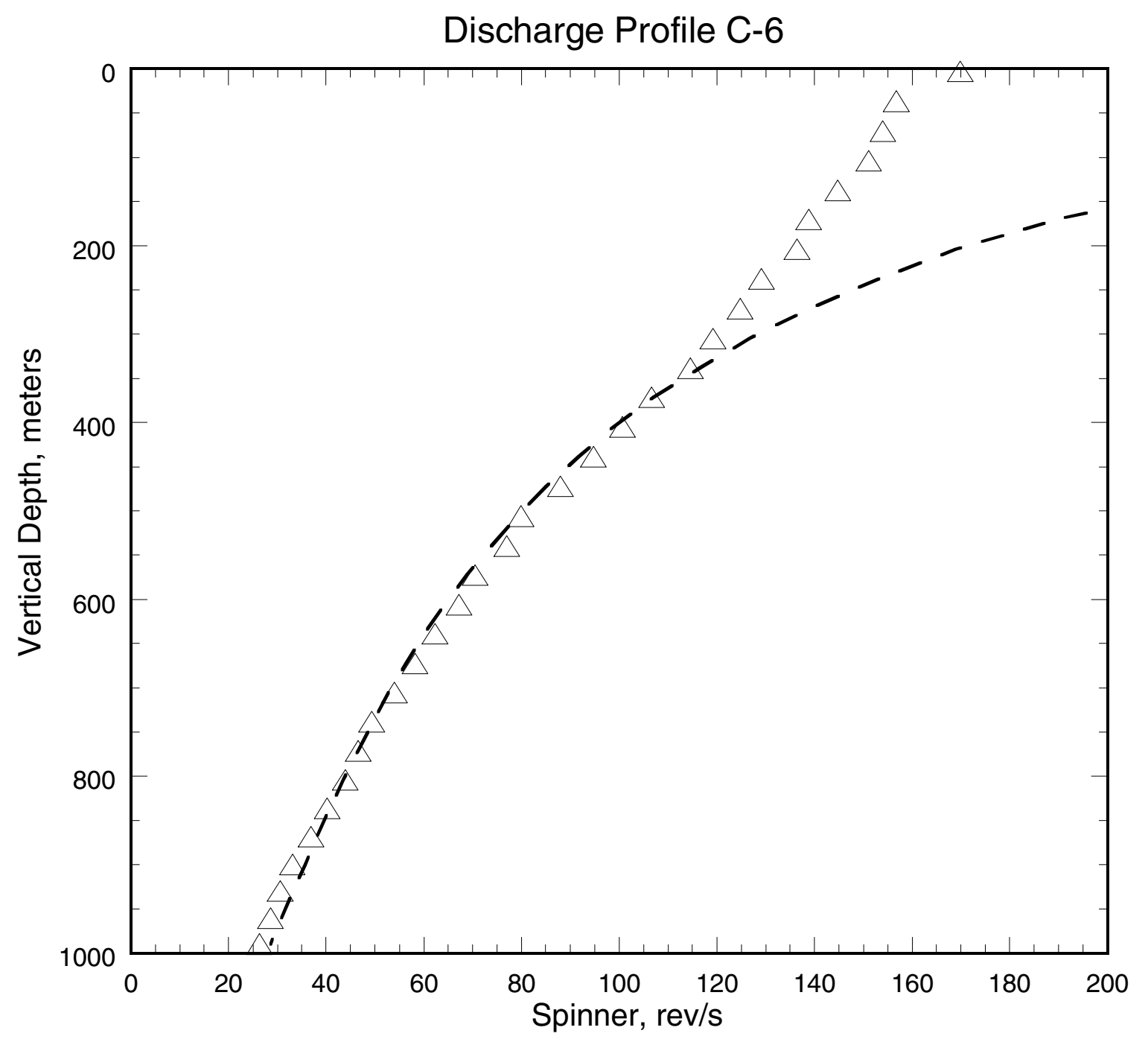

Figure D.27. Comparison of the smoothed spinner response (triangles) with the computed spinner response (dashed line) for well C-6. 


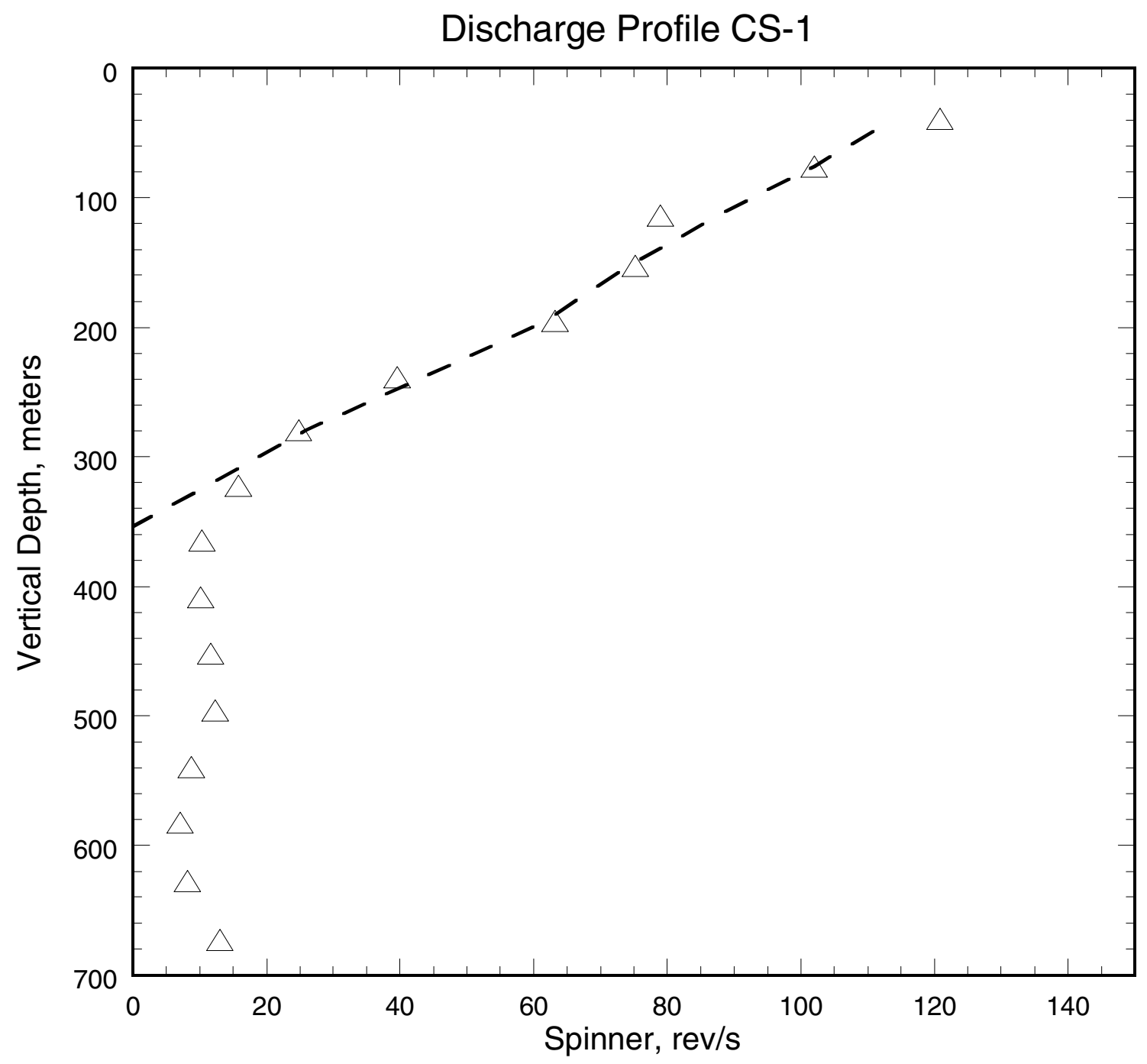

Figure D.28. Comparison of the smoothed spinner response (triangles) with the computed spinner response (dashed line) for well CS-1. 


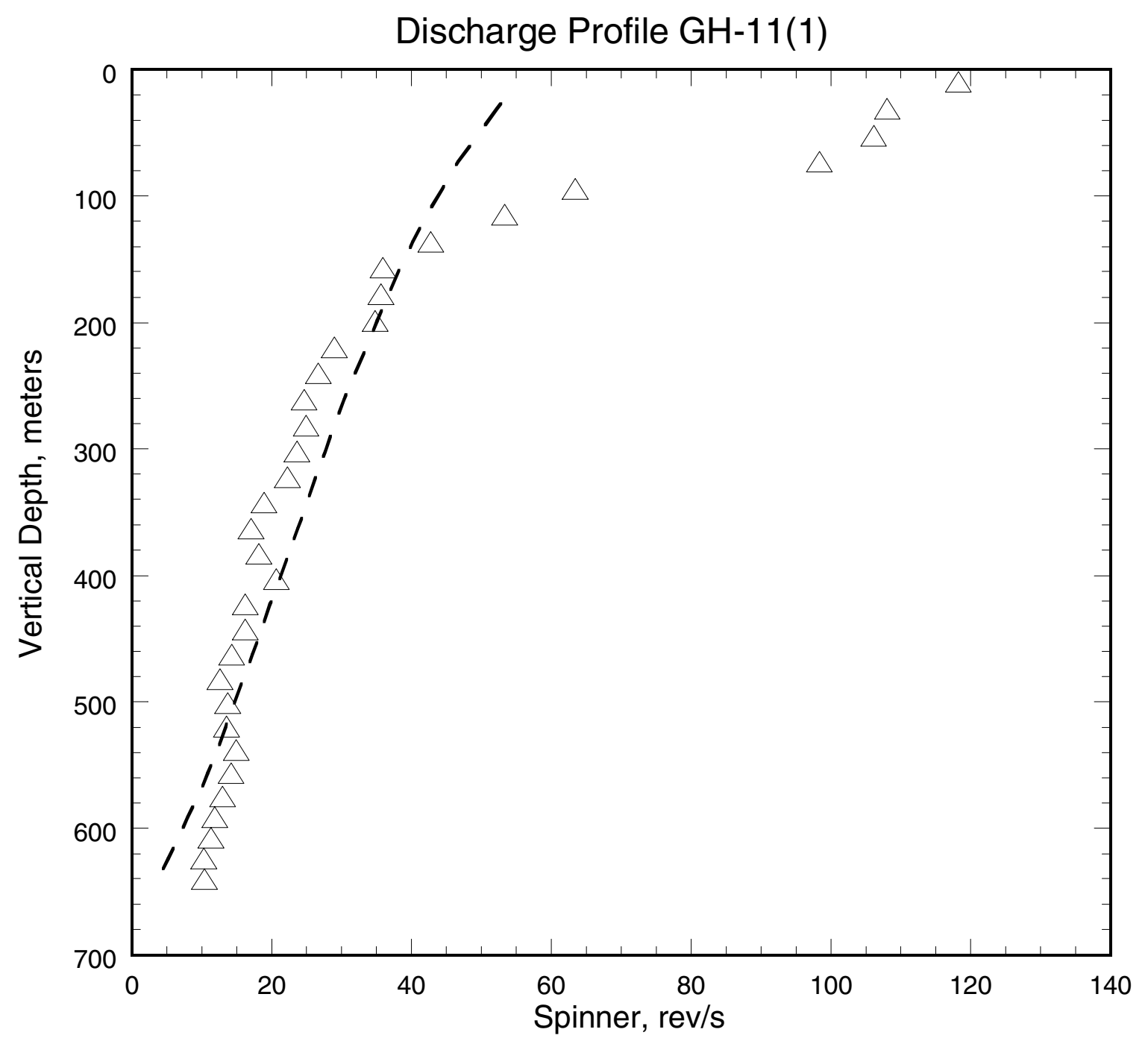

Figure D.29. Comparison of the smoothed spinner response (triangles) recorded on July 19, 1991, with the computed spinner response (dashed line) for well GH-11. 


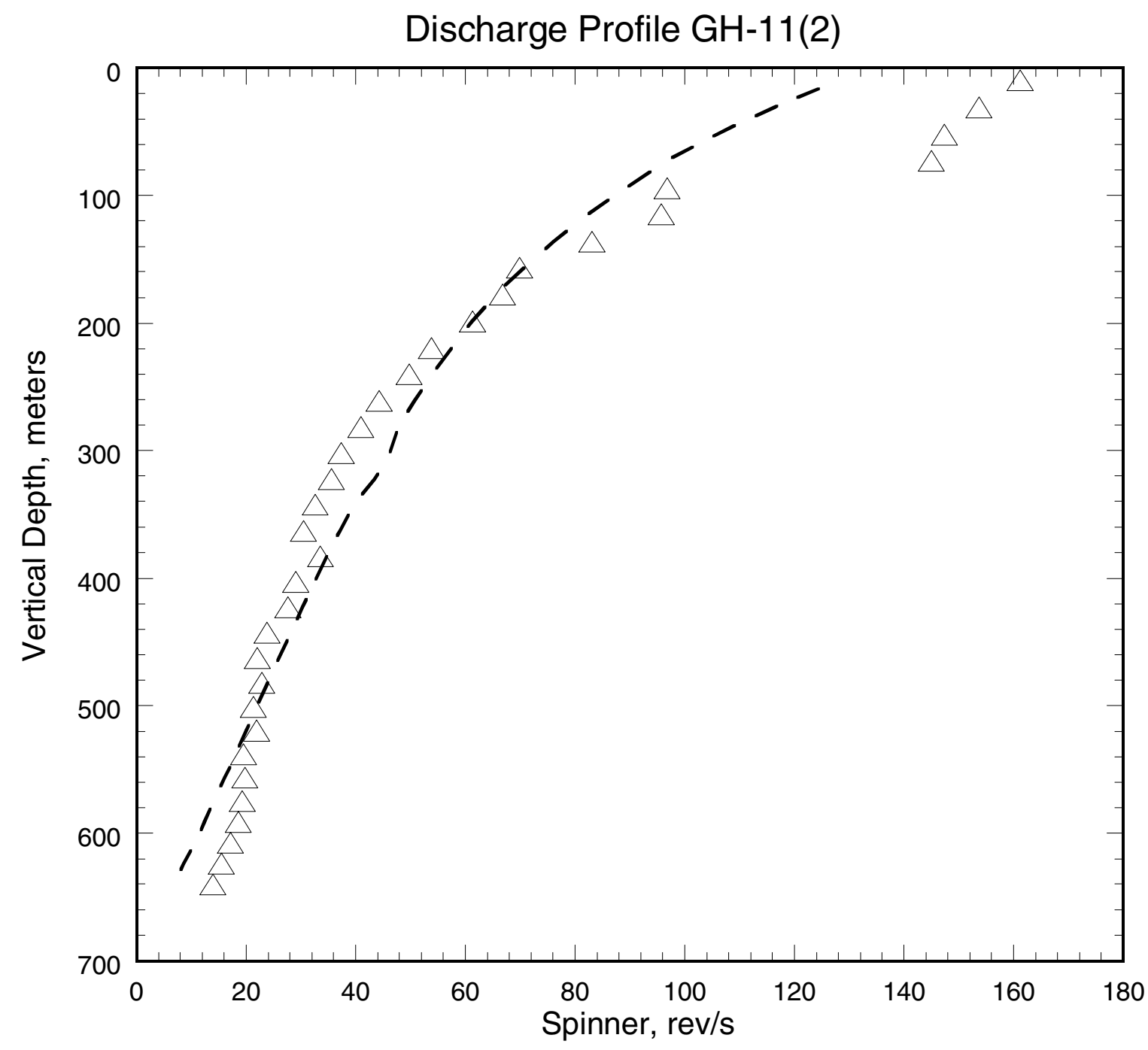

Figure D.30. Comparison of the smoothed spinner response (symbols) recorded on July 20, 1991, with the computed spinner response (solid line) for well GH-11. 


\section{APPENDIX E: FORTRAN SUBROUTINES USED FOR COMPUTING FLOW PARAMETER $K$ AND ITS DERIVATIVE WITH RESPECT TO FLOWING QUALITY}

\section{E.1 SUBROUTINE HLDFN1}

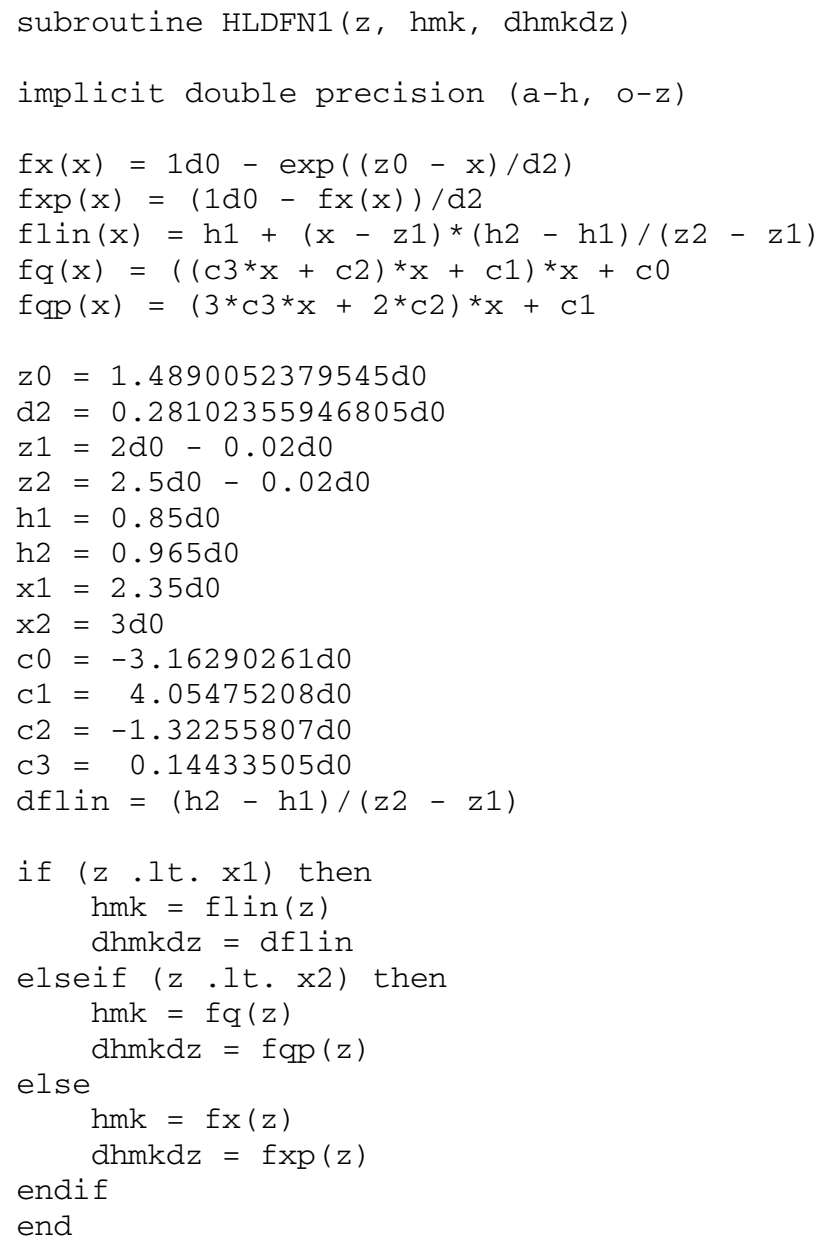




\section{E.2 SUBROUTINE HLDFN2}

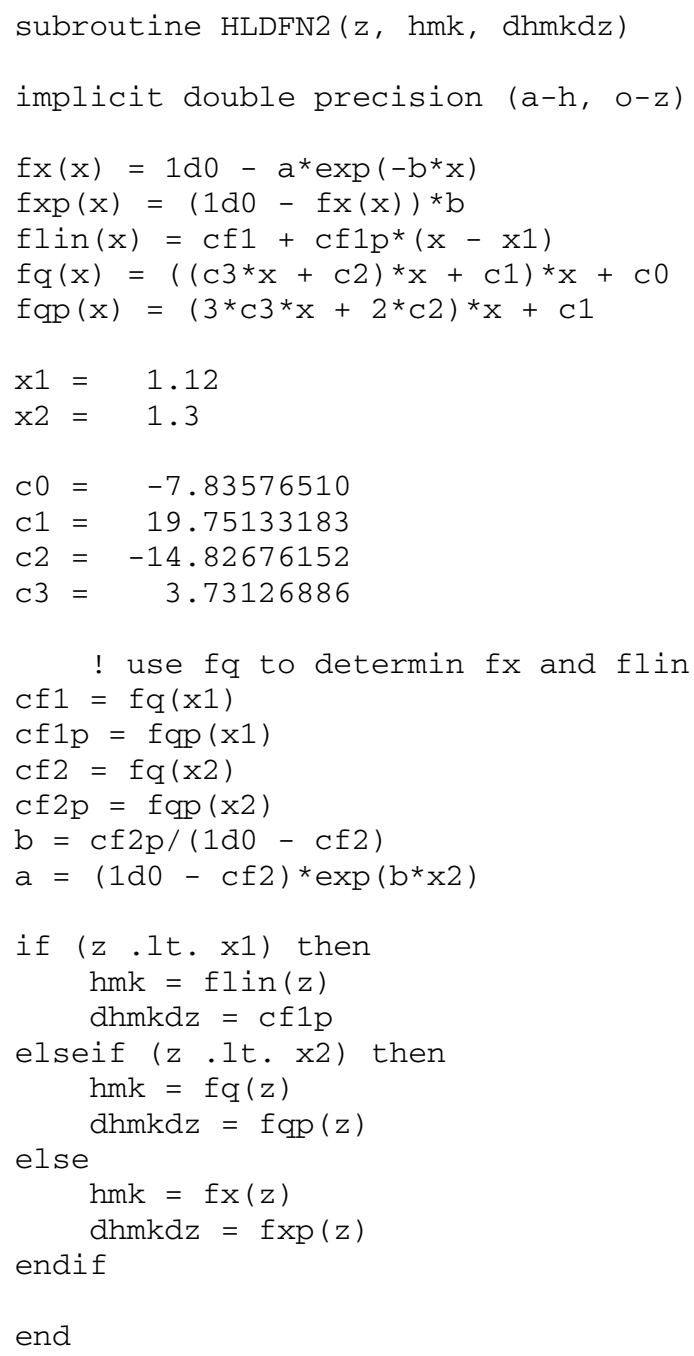




\section{E.3 SUBROUTINE HOLDFK}

Subroutine HOLDFK (FLOW, AREA, DIAM, RHOL, RHOG, VISL, VISG, GRAV, SRFT, 1

1

$\mathrm{QS}, \mathrm{QF}$,

$\mathrm{C}$

$\mathrm{C}$

C

C

PROGRAM TO CALCULATE STEADY TWO-PHASE FLUID UPFLOW IN A WELLBORE

IMPLICIT DOUBLE PRECISION (A-H, O-Z)

Input:

FLOW = mass flow rate, $\mathrm{kg} / \mathrm{s}$

AREA = cross-section area, $m * * 2$

DIAM $=$ diameter,$m$

RHOL = liquid density, $\mathrm{kg} / \mathrm{m} * * 3$

RHOG = gas density, $\mathrm{kg} / \mathrm{m} * \star 3$

VISL = liquid viscosity, $\mathrm{Pa}-\mathrm{s}$

VISG = gas viscosity, Pa-s

GRAV = positive gravity acceleration, $\mathrm{m} / \mathrm{s} * \star 2$

SRFT = surface tension, pa-m

QS = static steam quality

$\mathrm{QF} \quad=$ flowing steam quality

Output:

$\mathrm{XK}$ (dimensionless "K" function)

DXKDQF (derivative of "K" w.r.t. "QF")

DATA PI / 3.141592653589793D+00 /

C

DATA ALPHA1 /+0.0388887/

DATA BETA1 /0.0065170/

DATA GAMMA1 /-0.0002960/

DATA OMEGA1/-1.0d-1/

DATA ALPHA2 /-9.546812d-03/

DATA BETA2 /9.759590d-03/

DATA GAMMA2 /-1.498680d-04/

C

DATA OMEGA2 /-1.0d-1/

DATA FLUX1 /687. $d+0 /$

DATA FLUX2 /650.d+0/

$\mathrm{C}$

"Epslon" is the minimum value of $(1-Q F) /(1-Q S)$

DATA EPSLON / 1.D-02/

$\mathrm{C}$

C CALCULATE FLUX (Mass discharge per unit cross-sectional area)

FLUX $=$ FLOW/AREA

$\mathrm{C}$

C Calculate "Y" and its derivative w.r.t. QF

$\mathrm{DD} 1=(1 . \mathrm{D}+00-\mathrm{QF}) * \mathrm{RHOG}$

$\mathrm{DD} 2=\mathrm{QF} * \mathrm{RHOL}$

$\mathrm{DDD}=\mathrm{DD} 1+\mathrm{DD} 2$

$\mathrm{Y}=\mathrm{DD} 1 / \mathrm{DDD}$

$\mathrm{DYDQF}=-\mathrm{RHOL} *$ RHOG $/(\mathrm{DDD} * \mathrm{DDD})$

OMY $=1 . \mathrm{D}+00-\mathrm{Y}$ 
C

C Calculate liquid-phase saturation "SL"

OMQS $=1 . \mathrm{D}+00-\mathrm{QS}$

$\mathrm{SL}=\mathrm{OMQS} * \mathrm{RHOG}$

$\mathrm{SL}=\mathrm{SL} /(\mathrm{SL}+\mathrm{QS} * \mathrm{RHOL})$

C

$S G=1 \cdot d+0-S L$

C Calculate "rhoNs"

C

C Calculate "visNS"

C Calculate Reynolds \#

C Calculate Reynolds \#
$\mathrm{CR}=(4 . \mathrm{D}+00 * \mathrm{FLOW}) /(\mathrm{PI} * \mathrm{DIAM})$

$\mathrm{RE} \quad=\mathrm{CR} / \mathrm{VN}$

C Calculate Froude \#

$\mathrm{RN} 2=\mathrm{RN} * \mathrm{RN}$

FOA2 = FLOW $/$ AREA

$\mathrm{FOA} 2=\mathrm{FOA} 2 * \mathrm{FOA} 2$

$\mathrm{CF} \quad=\mathrm{FOA} 2 /(\mathrm{GRAV} * \mathrm{DIAM})$

$\mathrm{C}$

$\mathrm{FR} \quad=\mathrm{CF} / \mathrm{RN} 2$

C High Flux correlation (HLDFN1)

IF (FLUX . LE. FLUX2) GO TO 51

C Calculate "Z" parameter and derivative w.r.t. QF

$\mathrm{F} 1=\mathrm{RE} * \mathrm{ALPHA}^{*}$

$\mathrm{F} 2=\mathrm{FR} * * \mathrm{BETA} 1$

F3 $=\mathrm{Y} * *$ GAMMA1

$\mathrm{F} 4=\mathrm{SL} * * \mathrm{OMEGA} 1$

$\mathrm{DF} 3 \mathrm{DQF}=\mathrm{GAMMA} 1 * \mathrm{~F} 3 * \mathrm{DYDQF} / \mathrm{Y}$

$\mathrm{F} 124=\mathrm{F} 1 * \mathrm{~F} 2 * \mathrm{~F} 4$

$\mathrm{Z}=\mathrm{F} 124 * \mathrm{~F} 3$

$\mathrm{DZDQF}=\mathrm{F} 124 * \mathrm{DF} 3 \mathrm{DQF}$

C
C

Calculate "K" and its derivative w.r.t. QF

CALL HLDFN1 ( $Z, X K, D X K D Z)$

$\mathrm{DXKDQF}=\mathrm{DXKDZ} * \mathrm{DZDQF}$

$\mathrm{XK} 1=\mathrm{XK}$

DXKD1 $=$ DXKDQF

IF (FLUX.GE.FLUX1) GO TO 52

C Low Flux Correlation (HLDFN2)

C Calculate "Z" parameter and derivative w.r.t. QF 51 CONTINUE

$\mathrm{F} 1=\mathrm{RE} * * \mathrm{ALPHA} 2$

$\mathrm{F} 2=\mathrm{FR} * * \mathrm{BETA} 2$

F3 $=\mathrm{Y} * *$ GAMMA2

$\mathrm{F} 4=\mathrm{SL} * * \mathrm{OMEGA} 2$

$\mathrm{DF} 3 \mathrm{DQF}=\mathrm{GAMMA} 2 * \mathrm{~F} 3 * \mathrm{DYDQF} / \mathrm{Y}$

$\mathrm{F} 124=\mathrm{F} 1 * \mathrm{~F} 2 * \mathrm{~F} 4$

$\mathrm{Z}=\mathrm{F} 124 * \mathrm{~F} 3$

$\mathrm{DZDQF}=\mathrm{F} 124 * \mathrm{DF} 3 \mathrm{DQF}$

C

C Calculate " $\mathrm{K}$ " and its derivative w.r.t. QF

CALL HLDFN2 (Z, XK, DXKDZ)

$D X K D Q F=D X K D Z * D Z D Q F$

$\mathrm{XK} 2=\mathrm{XK}$

$\mathrm{DXKD2}=\mathrm{DXKDQF}$

C

IF (FLUX.LE.FLUX2) GO TO 52 
C

Transition zone

CONST1 $=($ FLUX1 - FLUX $) /($ FLUX1-FLUX2 $)$

CONST $=-$ CONST $1+1 \cdot \mathrm{D}+0$

$\mathrm{XK}=\mathrm{XK} 1{ }^{*} \mathrm{CONST}+\mathrm{XK} 2 * \mathrm{CONST} 1$

DXKDQF $=$ DXKD1 ${ }^{*}$ CONST + DXKD2 $*$ CONST1

C

C Enforce "epslon" limitation

52 CONTINUE

$\mathrm{XX1}=1 . \mathrm{D}+00-\mathrm{EPSLON} * \mathrm{OMQS}$

$\mathrm{XKSTAR}=\mathrm{QS} *\left(\mathrm{EPSLON} * \mathrm{OMQS}{ }^{*} \mathrm{RHOG}+\mathrm{XX} 1 * \mathrm{RHOL}\right) /$

C

$1 \quad\left(\mathrm{XX} 1 *\left(\mathrm{OMQS}{ }^{*} \mathrm{RHOG}+\mathrm{QS}{ }^{*} \mathrm{RHOL}\right)\right)$

C

IF (XK . GT. XKSTAR) RETURN

$\mathrm{XK}=\mathrm{XKSTAR}$

$\mathrm{DXKDQF}=0 . \mathrm{D}+00$

RETURN

C

END 